\title{
Universiteit
}

The Netherlands

\section{Movers and shakers: social movements in Africa}

Ellis, S.; Kessel, W.M.J. van

\section{Citation}

Ellis, S., \& Kessel, W. M. J. van. (2009). Movers and shakers: social movements in Africa. Leiden: Brill. Retrieved from https://hdl.handle.net/1887/18530

Version: $\quad$ Not Applicable (or Unknown)

License: $\quad$ Leiden University Non-exclusive license

Downloaded from: https://hdl.handle.net/1887/18530

Note: To cite this publication please use the final published version (if applicable). 


\section{Movers and Shakers}




\section{African Dynamics}

Editorial Committee:

Konings

Mathieu

Olukoshi

Posel

Watson

Volume 8 


\title{
Movers and Shakers
}

\section{Social Movements in Africa}

\author{
Edited by \\ Stephen Ellis \\ Ineke van Kessel
}

BRILL

LEIDEN, BOSTON

2009 
ISSN

ISBN 


\section{Contents}

\section{THEORETICAL PERSPECTIVES}

1 Introduction: African social movements or social movements in Africa?

Stephen Ellis \& Ineke van Kessel

2 Social movement theory: Past, presence \& prospects

3 Speaking to global debates through a national and continental lens: South African and African social movements in comparative perspective Adam Habib \& Paul Opoku-Mensah

\section{CASE STUdies}

4 African civil society, 'Blood Diamonds' and the Kimberley Process Lansana Gberie

5 The Islamic Courts Union:

The ebb and flow of a Somali Islamist movement Jon Abbink

6 Liberia's women acting for peace:

Collective action in a war-affected country 114 Veronika Fuest

$7 \quad$ Nurtured from the pulpit:

The emergence and growth of Malawi's democracy movement Boniface Dulani

8 Bare-foot activists:

Transformations in the Haratine movement in Mauritania 
9 An Islamic social movement in contemporary West Africa: NASFAT of Nigeria

Benjamin Soares

10 The United Democratic Front's legacy in South Africa:

Mission accomplished or vision betrayed?

Ineke van Kessel

11 'Campus Cults' in Nigeria:

The development of an anti-social movement Stephen Ellis

Bibliography

List of authors 


\section{Acknowledgements}

We would like to thank all those who have helped in the production of this book. This includes not only the authors of the various chapters, but all those staff members of the Afrika Studie Centrum, Leiden, who helped in the organization of the workshop and conference where the first drafts of the chapters were presented. In particular, we would like to thank our colleagues who have helped with the work of editing and preparation of the text of this volume, and especially Ann Reeves, Kiky van Oostrum and Mieke Zwart. Finally, we are most grateful to the Koninklijke Nederlandse Akademie van Wetenschappen (KNAW, the Royal Dutch Academy of Sciences) for its financial contribution to this project.

Stephen Ellis

Ineke van Kessel

Leiden, July 2009 



\title{
Introduction:
}

\section{African social movements or social movements in Africa?}

\author{
Stephen Ellis \& Ineke van Kessel
}

This volume is the outcome of a workshop and conference held in Leiden on 23-24 October 2008 and features the papers that were presented then, but were revised prior to publication. There were lively and highly focused discussions in the workshop on the first day of the proceedings and this introduction draws heavily on those debates and insights from all the participants.

It is appropriate to begin with an explanation of the thinking behind this project and to list some of the tentative conclusions that can be drawn. We began this venture with an open mind as to whether it concerned social movements as global phenomena that, in the present case, happen to be situated on the African continent or whether, on the other hand, we are dealing with social phenomena of a sort unique to Africa and which are therefore difficult to analyze in a comparative perspective. At the outset, we were unsure of the degree to which the theoretical work that has been done on social movements in general would be relevant to the study of African societies. We deliberately avoided beginning with a definition of a social movement drawn from the existing literature, which is largely based on studies of Europe, North America and Latin America, because that would risk excluding movements in Africa that might take a different form. We kept in mind the possibility that some social movements in Africa might be largely driven by outside stimuli in the form of inducements from aid donors. However, we also had to realize that if African movements are seen from the outset as sui generis, then not only does comparison with movements elsewhere become difficult, it also risks perpetuating the view that everything that occurs in Africa has its own special rationale, dictated by a context so radically different as to stand beyond global comparison. It would be better, we thought, first to assemble studies of at least some movements in Africa that 
could conceivably be described as social movements and only then to compare them with the existing literature.

To make this task possible, the first two chapters in this volume attempt a summary of the extensive literature that already exists on the subject of social movements. The first of these, by Jacquelien van Stekelenberg and Bert Klandermans, presents an overview of the development of social movement theory over several decades. They describe how early writers on the issue tended to view public protest as arising from impatience with more orthodox forms of interaction. When people took to the streets, this was stated or implied to be a sign of an irrational element inherent in mass action. Over time, this classic paradigm became increasingly unsatisfactory and was supplemented or replaced by analyses of the structure of social movements by writers who emphasized its political element. Social constructionist theories posed a series of questions about how individuals and groups perceive and interpret socio-political conditions, focusing on the cognitive, affective and ideational roots of contention. These theories tend to view social movements not only as a rational form of response but even as a necessary element of democracy. Many social movement theorists are themselves activists or former activists and they tend to emphasize the rational element in protest action. Some of the authors in the present volume have also played an activist role in the movement they describe, or in other social movements. Africa is quite familiar with the phenomenon of the scholaractivist, as is illustrated in the examples of Mahmood Mamdani, Jacques Delpechin and many others from all parts of the continent. In this respect at least, Africa fits quite well into the global landscape of social movements. Most recently, analysts have tended to observe the changing forms and goals of social movements in the light of globalization and the rise of information technology, which have created new possibilities for networking far beyond local neighbourhoods or even the national context.

A second theoretical chapter has been contributed by Adam Habib and Paul Opoku-Mensah and deals with the literature on contemporary social movements in South Africa and in Africa more generally, questioning how data from Africa relate to the debates that have emerged in the global academy. Habib notes that two assertions have been widely made in the literature on social movements: first, that the fulcrum of social struggles for a human development agenda has shifted from the arena of production to that of consumption, and second, that struggles concerning identity are replacing ones overtly oriented towards material issues, especially in post-industrial societies. Habib feels that a more nuanced interpretation is required, as assertions such as these are not fully satisfactory when applied to the evidence from Africa. It is true that social struggles, especially in South Africa, have expanded into the arena of consumption perhaps unsurprisingly as South Africa, with Africa's largest economy by far, in 
some ways resembles the 'developed' countries of Europe and North America more closely than other parts of Africa do. However, not only have movements concerned with relations of production continued but they remain crucial to the sustainability of struggles concerning consumption. While identity movements and struggles are increasing, material issues are as relevant to these struggles as they were to earlier social movements. Habib argues that social movements are vital in many democratizing societies in providing the substantive uncertainty that is necessary to create accountability among political elites to their marginalized citizens, thereby advancing a more sustainable human-oriented development agenda. In effect, he maintains that social movements are vital for a functioning democracy, particularly in states with only one dominant party. But it does not necessarily follow that social movements themselves are inherently democratic.

After these general introductions to the literature, eight case studies are presented. These cover a wide - but not necessarily representative - range of social movements in Africa. They include the Islamic Courts Union in Somalia, Islamic social movements in southwest Nigeria, the legacy of liberation movements in South Africa, Catholic social movements in Malawi, the anti-slavery movement in Mauritania, the global campaign against blood diamonds, and women's movements in Liberia. There are also the so-called 'campus cults' in Nigeria that have emerged from the efforts by military governments to disrupt the student movement. These campus cults can thus be considered, quite literally, as an 'anti-social' movement.

We began this project, then, unwilling to apply a definition of social movements that is drawn from a literature strongly influenced by North Atlantic and Latin American data, and yet wanting to study a range of movements in Africa to see whether it was possible to discern any common threads among them. We decided that it was best to adopt a pragmatic approach that, at least at the start, was open-minded. In other words, we would bear in mind some of the provisional conclusions drawn from the literature on social movements and make use of the instruments of social movement theory, while remaining open to the possibility that not all aspects of the relevant African phenomena would necessarily fit into these theories.

Clearly certain questions of a universal nature can be asked about movements all over the world, and some crucial questions can usefully be posed regardless of geographical setting. For a long time, scholars have explored questions such as why people rebel or, perhaps more importantly, why they do not rebel.

In view of the diversity of the movements discussed in this volume, we asked our contributors to address the following issues: 
- What are the historical origins of the social movement being analyzed?

- How does it mobilize support? Who are the people likely to participate?

- In what ways does the social movement under scrutiny frame its message?

- How does it relate to other social movements?

- Is it still in existence? Has it ceased to exist? If so, how and why?

In the discussions that ensued during the workshop and conference in Leiden, participants heartily endorsed our approach of not starting with an orthodox theory and subsequently examining the extent to which African cases fitted it. It became apparent that many movements in Africa that could be called social movements inasmuch as they are rooted in social networks rather than in state policy and insofar as they are concerned with broad social issues, are of a rather hybrid nature when considered with reference to conventional social-science categories. They often display social, political and religious characteristics that overlap one another.

\section{The international context}

It became clear at an early stage in the discussion among the authors represented in this volume that, more than elsewhere, the international context in which social movements operate is of considerable significance. African states in general are particularly vulnerable to external pressures of various sorts in Africa. When considering the flow of different sorts of resources - financial, moral and political - in the constitution of African social movements, we should take care not to limit our vision to exchanges between Africa and the West. The Middle East, India, China and other Asian powers are fast becoming more important in this regard. By the same token, South Africa is assuming a significant role by offering funds and moral leadership to the rest of the continent, sometimes providing an entry point to Africa for international networks or organizations seeking to expand their activities.

The international human-rights discourse has provided inspiration and moral legitimation for a range of causes, including the campaign against slavery in Mauritania and that against blood diamonds in Sierra Leone. Furthermore, social movements in Africa frequently have a pan-African dimension. Thus, the president of SOS Esclaves in Mauritania drew inspiration from attending a meeting in Switzerland as well as from the World Conference against Racism, Racial Discrimination, Xenophobia and Related Intolerance that was held in Durban in 2001, while relying heavily on his alliance with an anti-slavery movement in Niger. Similarly, the campaign against blood diamonds in Sierra Leone served as a model for comparable movements in Angola and the Democratic Republic of Congo (DRC). Activists in Uganda campaigning against a proposed change in the constitution to allow yet another term for President 
Museveni sought advice from activists who had conducted a successful campaign in Malawi against a third term for their country's president. In South Africa, the international dimension was vital to the struggle against apartheid. International alliances gave access to weapons, money and ideas ranging from Marxism-Leninism to a liberal discourse on human rights, gender rights and gay rights. And the African-American connection in the United States was crucial in organizing sanctions.

This international connection to social activism in Africa is not only ideological in nature but also contains an important financial and logistical aspect. Many social movements in Africa are dependent on funding from external donors. However, there are also exceptions, as Ben Soares shows in his study of the NASFAT movement in Nigeria. Foreign funds may come either directly or through locally based non-governmental organizations (NGOs). Although donor dependency obviously has an effect on the form assumed by social movements in Africa, it would be a fundamental mistake to see these movements as no more than an extension of Western NGOs. Even when Africans are in receipt of funds, they are not passive, and relations with donors do not consist solely of a one-way flow of resources. Organic intellectuals in Africa have learned how to play the system to their own advantage, in a local variation of the well-known pattern of interaction between the local and the global spheres. If we take a longer-term historical perspective on this point, we can appreciate that an initial pattern of ideas flowing into Africa can become a reverse current in a later phase. A good example is the Christian missionary movement in Africa, which for many years was indeed one-way traffic, but in recent decades African Christian churches have reversed the flow by reaching out to other parts of the world. It is interesting to note that Europe, the continent that historically initiated the modern Christian evangelization of Africa, is now seen by many African Christians as a godless continent in need of spiritual reawakening.

Even when money and other resources are clearly flowing from the rich world to Africa, there may still be reciprocal elements to the relationship. In solidarity networks, the providers of money may need approval bestowed by their African counterparts. Without this blessing, the providers lack credibility and legitimacy. During the struggle against apartheid, many anti-apartheid movements in the West allowed the African National Congress (ANC) to set the agenda and define priorities. The ANC's blessing was itself a precious resource, as illustrated by the intricate distinctions assumed by the ANC's leadership in exile, which made subtle distinctions in addressing its Dutch allies: members of the Anti-Apartheids Beweging Nederland (AABN) were classed as 'comrades', while the activists of the Komitee Zuidelijk Afrika (KZA) were considered 
merely as 'friends'. ${ }^{1}$ Similarly, in the Sierra Leonean case described in this volume, Canadian activists, including some senior politicians, were legitimized in their campaign against blood diamonds by the support of African NGOs.

In a relationship where an external donor brings money and other resources and an African movement may bestow legitimacy, it is common practice to present different facets of a movement to different partners in different settings. Thus, the ANC in exile was wont to use a human-rights discourse in Western capitals, while using the vocabulary of anti-imperialism in conversations with its socialist allies. Fundraisers for the United Democratic Front (UDF) became particularly agile at playing the donors, using a human-rights discourse to finance a struggle that increasingly took on socially radical features in South Africa itself. Funds for the UDF-aligned media were sought by appeals to the universal principle of press freedom, while media activists inside South Africa saw their social-movement media as a weapon of political struggle, and had little patience with liberal notions of plurality. It is instructive to read Ineke van Kessel's chapter on how former activists now consider their activities of twenty years ago. But then again, the profile designed by the leadership of a movement may differ radically from the understanding of the same movement at grassroots level. In the case of the campaign against blood diamonds, which enjoyed great success at the beginning of this century, the international profile of the campaign organization closely resembled the standard format of Western NGO campaigns, but on the ground in Sierra Leone it functioned as part of local antiwar movements, as Lansana Gberie explains in his contribution in this volume.

The particular importance of the external dimension to African social movements can be placed within the context of a much wider set of relationships that could be termed 'extraversion'. ' Jean-François Bayart has demonstrated that the accumulation of political power and social prestige in many parts of Africa has, sometimes over a period of centuries, been dependent on access to external resources. The latter have included money and imported consumer goods, but also less tangible benefits. In return, African entrepreneurs have supplied their foreign interlocutors with other assets. Until the twentieth century this notoriously included slaves but it could also include access to mineral resources or other commodities required by international traders. In the industrial age, Africa has itself not been a significant producer of manufactured goods. The import of capital and goods from outside has been balanced by the provision of other services including political support required by donor countries for diplomatic pur-

1 Sietse Bosgra, 'From Jan van Riebeeck to solidarity with the struggle: The Netherlands, South Africa and Apartheid', in SADET (South African Democracy Trust), The Road to Democracy in South Africa, 3, part I, p. 556.

2 Jean-François Bayart, 'Africa in the world: A history of extraversion', African Affairs, 99, 395 (2000), pp. 217-267. 
poses, and various forms of moral legitimation. This form of exchange has historically taken many different forms from the age of mercantilism through to the age of the Millennium Development Goals, but a notable element of dependency has been the main characteristic of the relationship. This was seen many decades ago and incorporated into a formal theory, first elaborated by scholars of Latin America and subsequently adopted by Africanists, that was very influential in the last few decades of the twentieth century. ${ }^{3}$ Dependency theory, closely associated with Marxist scholarship, postulated that a core group of developed countries had historically used their power to construct a world system in which peripheral territories were kept in a permanent state of dependency, were needed for their raw materials and other assets but were prevented from developing the degree of industrialization or economic sophistication that would enable them to break out of their peripheral status. Dependency theory was largely superseded in Western academies of learning in the $1980 \mathrm{~s}^{4}$ but it has remained influential among African intellectuals.

As Bayart hints, ${ }^{5}$ many aspects of development theory actually remain more relevant and cogent than may appear at first sight, provided it is recognized that Africa's dependency is the historical consequence of action by various parties. It has not simply been imposed on Africa but has been historically formed by complex interactions. Dependency is a political resource that has been of considerable benefit to some of those Africans who have contributed to its elaboration. It is helpful to consider the relationship between African social movements and external funders in this regard. It is not just the imposition of a political project by the rich but an interactive relationship that has complex moral, political and financial elements. As Veronika Fuest points out in her study of the highly dynamic Liberian women's movement, which played an important role in bringing peace to that troubled country and whose success was crowned by the election of Africa's first elected female head of state to the applause of much of the world, it is also a movement that has been dominated by women from some of the country's elite. Families that have made their fortune over generations from their success in situating themselves at the juncture of Liberian society and its external links, most notably with the US, may in a sociological sense be carrying on a family tradition more than they are articulating a 'new' social movement.

3 See notably Walter Rodney, How Europe Underdeveloped Africa (Bogle-L'Ouverture Publications, London, 1972).

4 Cf. Colin Leys, The Rise and Fall of Development Theory (James Currey, Oxford, 1996).

5 Bayart, 'Africa in the world', pp. 219-220. 


\section{Diasporas}

Related but distinct is the relationship between social movements in Africa and African diaspora communities in the rest of the world. In recent decades, the number of Africans living permanently or semi-permanently outside their continent of origin has increased enormously. African communities are now a permanent feature in many parts of Europe, North America and the Middle East, and increasingly in Asia as well. Many diaspora communities retain a close interest in their countries of origin, sending remittances home for the upkeep of their families, making trips home whenever possible to supervise the construction of a house, and often contributing money to help finance the building of churches or mosques. Many people living abroad naturally retain a close interest in news from home, discussing matters with friends, perhaps reading the press online and keeping in touch by phone.

Contacts with people living in the diaspora can have an important effect on social movements in Africa itself, and indeed this is one of the most prominent elements of numerous African social movements. Yet in our survey of the theoretical literature on social movements and in the expert summaries contained in the first two chapters of this book, we find little or nothing about the role of diaspora communities in the dynamics of social movements. Similarly, political scientists have generally not devoted much attention to the notion of diaspora states such as Eritrea and Somalia, societies that are kept afloat largely by migrant remittances and where even the state may be heavily reliant on funding or other contributions from the diaspora. The latter is a source not only of money but may also provide remittances of a social and moral nature. From Islamic clerics to Marxist students and from gender activists to campaigns for global justice, African diaspora communities play a vital role in the flow of ideas. Decades ago, when diaspora communities were less numerous, the flow of ideas was on a relatively small scale but with the advent of the Internet, fax and cell phones it has developed the potential to become an instant tidal wave. The potential for global mobilization has become greater than ever before. The types of people who live in diaspora communities may vary from one context to another, making it important to identify the social profiles of people who move out of the country as well as where they move to. As Boniface Dulani notes, it tends to be critics of the regime in place who leave a country. This might not be for political reasons in the first instance but residence abroad may cause them to become more critical of their home government. Moreover, diasporas are to be found not only in the rich world but also in Africa itself. In the case of Malawi, many exiles in the time of Life President Dr Hastings Kamuzu Banda went to live in Zambia and Tanzania, from where they could play an active part in the 1990s democratization campaign that eventually succeeded in removing him 
from office. But, as Dulani points out, actions by exiles can only be effective if there is also an internal challenge to the regime.

The relationship between internal and external components of African social movements can draw on many other examples. Thus, the ANC mission-in-exile for three decades conducted both armed insurgency and a diplomatic campaign against apartheid but its activities only became really effective in the 1980s when the movement's exiled leadership was able to link up with internal movements, notably the rapidly growing trade-union movement and the United Democratic Front. Another example is provided in this volume by Lansana Gberie, who describes the role played by the Liberian and the Sierra Leonean diasporas in the blood-diamonds campaign, which was also taken up as a foreign-policy instrument by countries in Europe and North America. Conversely, in the case of Mauritania's anti-slavery movement, Ould Zekeria attaches little importance to the Mauritanian diaspora, pointing out that Mauritanians abroad tend to be overwhelmingly from families of the country's slave-owning elite rather than descendants of slaves or ex-slave families. Moreover, most of the Mauritanian diaspora is located in the Arab world where anti-slavery agitation is little known. In fact, Mauritania's slave-owners use Islam as a discourse to legitimate practices of slavery. This, too, strengthens the argument not only for considering the role of diaspora populations in Africa's social movements but also for appreciating the social nature of a particular diaspora population. There are very few Mauritanian Arabic speakers in Europe and North America. The non-Arabic-speaking diaspora in those areas is larger, however, and has a significant impact on the internal politics of racism and ethnic conflict, while keeping slavery alive as an issue in the foreign media.

\section{State and non-state}

A further specificity of social movements in Africa is that they often exist in countries where the state is much weaker than it is in Europe or North America, or where it barely even exists at all in the sense of hosting a bureaucracy that is able to implement synchronized activity in fields such as policing, justice or other functions that would normally be regarded as essential to any state. The most extreme example in Africa today is Somalia, and Jon Abbink's chapter on the Islamic Courts Union in Somalia raises the interesting question of whether it is actually permissible to speak of social movements in the effective absence of a state. So much of the literature produced on the basis of case studies from other continents implies, at the very least, that social movements are in some sense the natural adversary of the state since they frequently formulate demands for state action or, alternatively, protest against such action. By the same token, social movements are often considered to articulate a vision of an alternative 
social order, realistic or otherwise. But here again, we can find examples in Africa of social movements that develop a pragmatic partnership with the state or that identify other adversaries. An example is the Treatment Action Campaign (TAC) in South Africa, one of that country's most effective civil-society coalitions since the end of the apartheid era, that initially targeted the pharmaceutical industry in its efforts to provide access to generic anti-retroviral drugs for HIV/AIDS patients. Only in a later phase did the South African government become the TAC's main opponent, as the activist movement campaigned to make anti-retrovirals widely available to people living with AIDS. Ultimately, the TAC won its most significant battle in the courtroom, an organ of the state itself, even though it took years before the government effectively implemented the court's verdict. Recourse to the courts is a route sometimes taken by environmental movements and gender activists but also by movements seeking broader goals, such as the UDF in South Africa. For labour movements in Africa and elsewhere, capital is usually the primary opponent but they may eventually direct their campaigns at the state with demands to initiate or enforce legislation on labour conditions such as a minimum wage, safety standards and/or social benefits.

Another instrument associated with states but that can be mobilized by social movements to advance their cause is diplomacy. Of the cases analyzed in this volume, the one that relied on this technique most heavily was the campaign against blood diamonds that was primarily initiated by a Canadian NGO with an African connection and supported by the Canadian government. Thereafter, the blood-diamonds campaign came to receive the support of other governments and even the United Nations, which applied legal sanctions on diamonds emanating from some war zones. At first sight, one might suppose that the blooddiamonds campaign, which was remarkably successful in pricking the conscience of consumers in the rich world and initiating international action, was actually non-African in almost everything but its effects. However as Lansana Gberie shows, the campaign was supported by local activists in Sierra Leone who were able to use this powerful international campaign to further their own agendas. It is one of many examples of where social activists in an African country are able to leverage their influence by recourse to various forms of state action, in this case overwhelming on the part of states external to the region.

From Nouakchott to Johannesburg, shaming a government can be quite an effective tactic in realizing social goals. The Mauritanian anti-slavery group SOS Esclaves has used this strategy to particularly good effect, and each time Mauritania is exposed as one of the world's last outposts of slavery, its government feels humiliated. Since slavery has already been legally abolished in Mauritania, the government often simply resorts to the politics of denial. 
There is an embedded religious element associated with many social movements in Africa. In North America, Europe and other locations where social movements have been extensively studied, churches or other religious groups, considering themselves to have a special moral role as guardians of society's ethics, may initiate a social campaign, for example in opposition to abortion in the US, that employs many of the classic tactics of social movements in general. In the case of the anti-abortion movement, this is largely aimed at overturning a Supreme Court ruling on the legality of abortion. In other instances, a social movement with a broad social base may enlist particular support from churches or other religious groups if they perceive it to have a particularly moral aspect, such as the Campaign for Nuclear Disarmament in the UK. In an earlier period, religion was central to the campaign to abolish the slave trade founded in Britain in the eighteenth century, and this is often seen as the first modern social movement. In the US, religious institutions contributed powerfully to the US civil-rights movement that had such an enormous effect not only on US politics and society but also on the way social movements were perceived by academic writers. In Africa however, entire social movements may appear to be preoccupied with religious issues to the apparent exclusion of more conventional forms of social action. A highly controversial case is the student Pentecostal movement in Nigeria, which can be viewed simply as a religious movement operating outside the purview of the state or of political demands but is more persuasively seen as a movement for the renewal of the social contract binding society and state that takes a distinctive form. ${ }^{6}$ The 'campus cults' described in Stephen Ellis's chapter can be seen as youth gangs with innocuous origins as student clubs that, over two or three decades, were manipulated by Nigerian military governments to break the power of the country's student movement, which was so feared by the military on account of its potential for mobilizing force. What is of particular interest in this regard is that the Pentecostal movement that emerged on Nigerian campuses in the 1970s was also vying for the allegiance of students, and identified the campus gangs not merely as anti-social elements but as Satanic, implying a very particular theological character. This attitude is best understood not merely as a reaction to the violent nature of Nigeria's campus cults but as a reflection of a long history of initiation societies in which social power is deemed to be derived from contact with the invisible world.

Much of the academic literature on religious movements in Africa bases itself on a materialist analysis. It departs from the supposition that religious ideas and practices do not have any substance in and of themselves, viewing them as clues to the nature of the forces that truly shape society, assumed by

6 Cf. Ruth A. Marshall, Political Spiritualities: The explosion of Pentecostalism in Nigeria (Chicago University Press, Chicago and London, 2009). 
many social scientists and historians to be those related to physical resources and material reality. However, if we think of religion in terms of spiritual power, and religious practice as access to that power, ${ }^{7}$ its political dimensions become fully apparent. The NASFAT movement in southwestern Nigeria does not articulate any demands that might be considered political by reference to conventional state politics. However in a Nigerian context where religion is generally considered in terms of spiritual power and where state politics are notoriously empty of moral content, a religious movement acquires a political connotation that it might not have in another context. This is even more evident in the case of the Islamic Courts Union in Somalia presented by Jon Abbink. In Somalia, where a functioning state barely exists, such a religious movement assumes a very obvious political role.

For the rest, social movements in Africa can and do make use of the gamut of methods that are commonly associated with social movements the world over. These include demonstrations, the use of the mass media to broadcast a message to a wider audience and tactics of civil disobedience designed to attract public attention and frustrate the state with a view to causing it to pay attention to activists' demands.

\section{Framing}

One of the most interesting aspects of social movements is the issue of their 'framing' or, in other words, the general context in which any given action or repertoire of actions is presented or interpreted. In many of the best-known cases, a relatively simple and localized set of activities may be presented by skilled leaders as something much larger. An example is when the sabotage of an oil pipeline in southern Nigeria, perhaps even by a group that is situated halfway between a social group and a money-making venture, is presented as an attack on the collaboration between oil companies and the Nigerian state. Nor is it only local leaders who sometimes present their movements in these broad terms. As research on social movements is currently fashionable in the acadamic world, researchers are apt to spot social movements in every corner of the world.

The point of this last remark is not to suggest that there were no social movements before social scientists arrived to describe and analyze them in terms of a sophisticated theory. Similar movements surely existed prior to this but were labelled differently. This seems to be a particularly important point with regard to Africa where a great deal of writing in both academic journals and the press has been based on the supposition that societies steeped in tradi-

7 Argued in Stephen Ellis \& Gerrie ter Haar, Worlds of Power: Religious thought and political practice in Africa (C. Hurst \& Co., London, 2004). 
tion have been making their way into the modern world. It is quite easy to find examples of many movements intent on dealing with matters of widespread concern within a given society or community but that have been classified as anti-witchcraft movements or messianic movements or otherwise relegated to various categories of traditionalism. In retrospect, one may also wonder whether the mass mobilization of societies in the final years of colonial rule, which in most of Africa was in the 1950s, that was generally analyzed by historians and political scientists in terms of nationalist movements may not also be usefully seen as an example of social movements. Our purpose in saying this is not to argue that the people who demonstrated in favour of independence fifty years ago were not real nationalists but to argue that a recurring theme in African history is the mobilization of significant numbers of people around issues that preoccupy or interest them. These are socially rooted and often have a religious aspect but may also be articulated by leaders in terms of precise political demands. The form that the latter take is strongly influenced by the nature of the state in any particular case. In the heyday of nationalism, it made sense to 'frame' social struggles in the national context, just as in the struggle against apartheid it made sense to do the same with concerns about rent increases and electricity supply problems, presenting them as secondary consequences of the core problem. When a state does not effectively exist, as in Somalia today, struggles for social issues will be presented differently.

This point of view finds an echo in some of the existing literature on social movements in Africa. In his critique of the state-centrist and society-centrist perspectives prevailing among Africanists in the West, Mahmood Mamdani questions the universalist pretensions of a civil-society-governed perspective. He wonders whether the civil-society discourse is no more than a restatement of an earlier perspective, that of modernization theory, with its notion of the 'traditional' as the problem and the 'modern' as its salvation. In his view, the concept of civil society allows almost no room for the 'traditional'. The same might be said about social movement theory. Ifi Amadiume, one of the contributors to the volume on social movements edited by Mamdani and Ernest Wamba-dia-Wamba, ${ }^{8}$ argues that the idea that social movements are seeking social or political change is too limited. She proposes instead an example of anti-power movements that simply seek to defend and maintain their own autonomy, and identifies this trait as the central characteristic of indigenous women's movements in Africa. These movements, she argues, may be considered

8 Mahmood Mamdani \& Ernest Wamba-dia-Wamba (eds), African Studies in Social Movements and Democracy (Codesria, Dakar, 1995). 
'traditional', but they are not 'pre-modern'. ${ }^{9}$ Another relevant example mentioned in the same volume is the case of labour unions in Zimbabwe. These, it is argued, grew out of burial societies formed by workers and small traders or entrepreneurs. In the Eurocentric perspective on labour history, this type of community organization is situated on the lower levels of an evolutionary scale that culminates in full-blown class-conscious labour unions as the most mature stage. Such a perspective blinds us to the real dynamics of African labour movements and of a repertoire of protest and resistance that is much broader and more diverse than strikes and boycotts alone. ${ }^{10}$

We consider this a valid perspective and the absence of case studies of 'traditional' movements in this volume does not imply that we see social movements as an exclusively modern phenomenon. While we have hardly explored the realm of the 'traditional', other perhaps than in passing in the case of the Nigerian 'campus cults' that bear such a close resemblance to traditional initiation societies, we have attempted to situate the study of social movements in Africa in the broader context of social movement theory.

\section{Chronology: Generations of social movements?}

By the 1990s, it had become received wisdom in social movement theory that an earlier generation of social movements had been succeeded by a generation of so-called 'new social movements'. Thus, the first edition of the authoritative book by Donatella della Porta and Mario Diani ${ }^{11}$ strongly endorsed the paradigm of 'new social movements', that is movements that had developed since the late 1960s relating to issues such as women's rights, gender relations, environmental protection, ethnicity and migration, peace and international solidarity. These new movements were perceived as having a distinctly middle-class basis. Sporting the label 'new', the movements were clearly differentiated from the models of working-class or nationalist collective action that had historically preceded them. However, in the second edition of their book, which was published in 2006, these authors question the neat transition from working-class to middle-class activism that they had earlier espoused. The reason for their doubts was the sustained challenge mounted by broad coalitions of very heterogeneous actors against neoliberal globalization. The 'Battle of Seattle', when

9 Ifi Amadiume, 'Gender, political systems and social movements: A West African experience', in: Mamdani \& Wamba-dia-Wamba (eds), African Studies in Social Movements, pp. 35-68.

10 Introduction to Mamdani \& Wamba-dia-Wamba, African Studies in Social Movements, p. 12.

11 Donatella della Porta \& Mario Diani, Social Movements: An introduction (Blackwell, Oxford, 1999). 
large numbers of demonstrators gathered to protest during a World Trade Organization ministerial conference in 1999, was seen as the beginning of a new phase. It showed the ability of demonstrators from all over the world and a great variety of backgrounds to express their views in a context where neo-liberalism was no longer regarded as the only viable path to development but was highly contested. The global financial crisis that began unfolding in 2008 has served to further undermine the dogmas of the so-called Washington Consensus, giving new impetus to campaigns for sustainable development and global justice as well as new legitimacy to local struggles against privatization and commercialization. In the preface to their 2006 edition, Della Porta and Diani remark that there are surely continuities between the generation of 'new social movements' and the contemporary wave of global justice campaigns. However in addition to continuities, they also perceive new patterns of collective action that are significantly different from the familiar characteristics of largely middle-classbased movements. Working-class action, they observe, seems to be back with a vengeance.

This shift in paradigm helps to narrow the gap between social movement theory and the African experience. Movements in Africa never did fit into the sketch of a neat chronological succession from working-class to middle-class activism or, in Habib's phrase, from the arena of production to the arena of consumption. Labour struggles in Africa have not come 'back with a vengeance', as they have always been an integral part of a wide range of social movements, even if the study of working-class action became less fashionable in the era when so many academic researchers were preoccupied with postmodernity. Recent examples include Zimbabwe, where the trade-union movement has been instrumental in building the opposition coalition assembled under the umbrella of the Movement for Democratic Change. In South Africa, the labour movement constituted a vital part of a broader anti-apartheid coalition. Even the struggle against hereditary slave labour is not over in Africa, as Zekeria Ould Ahmed Salem's chapter on SOS Esclaves in Mauritania shows.

At the end of this exercise, we are left with the impression that social movements abound in Africa and that they inevitably adopt particular features as a result of the social and political context in which they operate. When a significant part of a country's population lives abroad, the diaspora may take on an important role in framing debates or interpreting them for the outside world. Religious debates that might sometimes appear almost other-worldly can assume a distinct social and even political colour in a situation where the state itself is seen as being morally void, or is hardly present at all. Traditional and new forms may be inextricably mixed. If this gives food for thought for theoreticians of social movements, then this volume has served a dual purpose: 
documenting a few examples from the great diversity of social movements in Africa as well as contributing to more inclusive social movement theories. 


\title{
Social movement theory: Past, present and prospects
}

\author{
Jacquelien van Stekelenburg \& Bert Klandermans
}

When and why do people protest? And who is likely to participate in public protests? Around 1900, influential sociologists regarded all street protest as deviant behaviour. The classic paradigms held that (relative) deprivation, shared grievances and generalized beliefs were determinants of protest. The early scholars of contentious politics depicted protest as the politics of the impatient, maintaining that protest had an irrational element to it. As dissatisfaction with these classic paradigms grew, new ones emerged: structural paradigms such as resource mobilization and political process. While resource mobilization theory focuses on organization as a resource, political process theory emphasizes the political element of protest. Simultaneous with the rise of the structural paradigms was the emergence of social-constructivistic paradigms that concentrate on how individuals and groups perceive and interpret socio-political conditions. They focus on the role of cognitive, affective and ideational roots of contention and are broadly organized around three concepts: framing, identity and emotions. This chapter discusses these concepts as well as the social-psychology approach to social movements. The sociopolitical context of contentious politics is changing due to processes such as globalization and liberalization, and it is argued that these changes influence the rise and fall of social movements and their collective actions. Most social movement scholars assume that mutual integration of the structural and constructivistic paradigms can yield satisfactory explanations. 


\section{Social movements and collective action}

The reason why people protest has occupied social scientists for a long time. The French psychologist Le Bon, a founding father of collective action studies, regarded all street protest as a form of deviant behaviour and developed his theory on crowds during a period of great social unrest in France in the 1890s. He believed that the destruction of religious, political and social beliefs in combination with the creation of new conditions of existence and thought as a result of the modern scientific and industrial discoveries of the time were the basis for a process of transformation of mankind's thought. Ideas from the past, although half shattered, were still very powerful he believed, while the ideas that were to replace them were in a process of formation. The consequence, in his analysis, was a period of transition and anarchy. Le Bon's ideas were reflected in classic breakdown theories that regarded participation in collective action as an unconventional, irrational type of behaviour. ${ }^{1}$ The classic paradigm held that (relative) deprivation, shared grievances and generalized beliefs were determinants of participation. In fact, early students of the subject depicted contentious politics as the politics of the impatient and maintained that protest had an irrational element to it. ${ }^{2}$

Times changed and so did both contentious politics and theoretical approaches to contentious politics. The late 1960s saw a huge growth in social movement activity: the student movement, the civil-rights movement, the peace movement, the women's movement and the environmental movement all flourished. Interpretations of major forms of collective action changed from being viewed as spontaneous 'irrational' outbursts to movement activities with concrete goals, articulated general values and interests, and rational calculations of strategies. Breakdown theories clearly fell short as explanations of this proliferation of social movement activity, all the more so because it seemed to be preceded by growing rather than declining welfare. This, combined with changing forms of collective action, required new theoretical approaches, and several developed in the 1970s.

These new theoretical approaches can be categorized as structural and social constructivistic paradigms. Resource mobilization and political process are examples of structural approaches. While resource mobilization places an emphasis on organizational aspects and resources, the political process approach emphasizes the political aspects of collective action. The social constructivistic perspective, on the other hand, concentrates on how individuals and groups perceive and interpret these conditions and focuses on the role of the cognitive,

1 B. Klandermans, The Social Psychology of Protest (Blackwell Publishers, Oxford 1997).

2 N.J. Smelser, Theory of Collective Behavior (The Free Press, London, 1962). 
affective and ideational roots of contention. It is broadly organized around three concepts: framing, identity and emotions (culture is also referred to but is not elaborated on in this chapter). These terms are also key concepts in social-psychology approaches to protest. Social psychologists maintain that people live in a perceived world and respond to the world as they observe and interpret it. To understand why people protest, it is necessary to know how they see and interpret their world, and social psychology focuses on subjective variables. Socialpsychology approaches are, therefore, prototypical to social constructivistic approaches.

Obviously, the past and the present of social movement theory reveal different paradigms stressing various aspects of social movements and the actions they stage. They provide different answers to questions about why people protest, who protests and the forms of protest that protesters are involved in. Table 1 provides an overview of the answers provided to these questions by the different approaches to social movements.

Since the 1990s the context of contentious politics has changed significantly. Inseparably intertwined processes such as globalization, the development of the network society and the information society have given the world a new look. Networks are becoming the prime mode of organization, with formal networks embodied by organizations giving way to less formal networks rooted in the personal life world of individuals and to more diffuse group belongings. ${ }^{3}$ Moreover, the rise of new communication technologies (the Internet, email, cell phones) is intensifying change and its pace.

Fundamental changes in society can affect contentious politics. After all, the spread of information and networks are essential elements of mobilization and one assumes that such fundamental changes are having a profound impact on the dynamics of contention. Indeed, scholars of social movements argue that recent social and cultural changes have lead to a 'normalization of protest' ${ }^{4}$ and have created a social movement society. ${ }^{5}$ This has posed new challenges to social movement theory. Are dynamics of contentious politics? In the final section of this chapter we will elaborate on what we see as the prospects of social movement theory and relate them to developments on the African continent. This is a precarious undertaking, especially considering the rapid pace of change.

3 J.W. Duyvendak \& M. Hurenkamp (eds), Kiezen voor de Kudde. Lichte gemeenschappen en de nieuwe meerderheid (Van Gennep, Amsterdam, 2004).

4 P. Norris, S. Walgrave \& P. van Aelst, 'Who demonstrates? Anti-state rebels, conventional participants, or everyone?', Comparative Politics, 37, 2 (2005), pp. 189205.

5 D. Meyer \& S. Tarrow (eds), Towards a Movement Society? Contentious politics for a new century (Rowman and Littlefield, Boulder, CO, 1998). 
Table 1 Theories on participation and the emergence of social movements

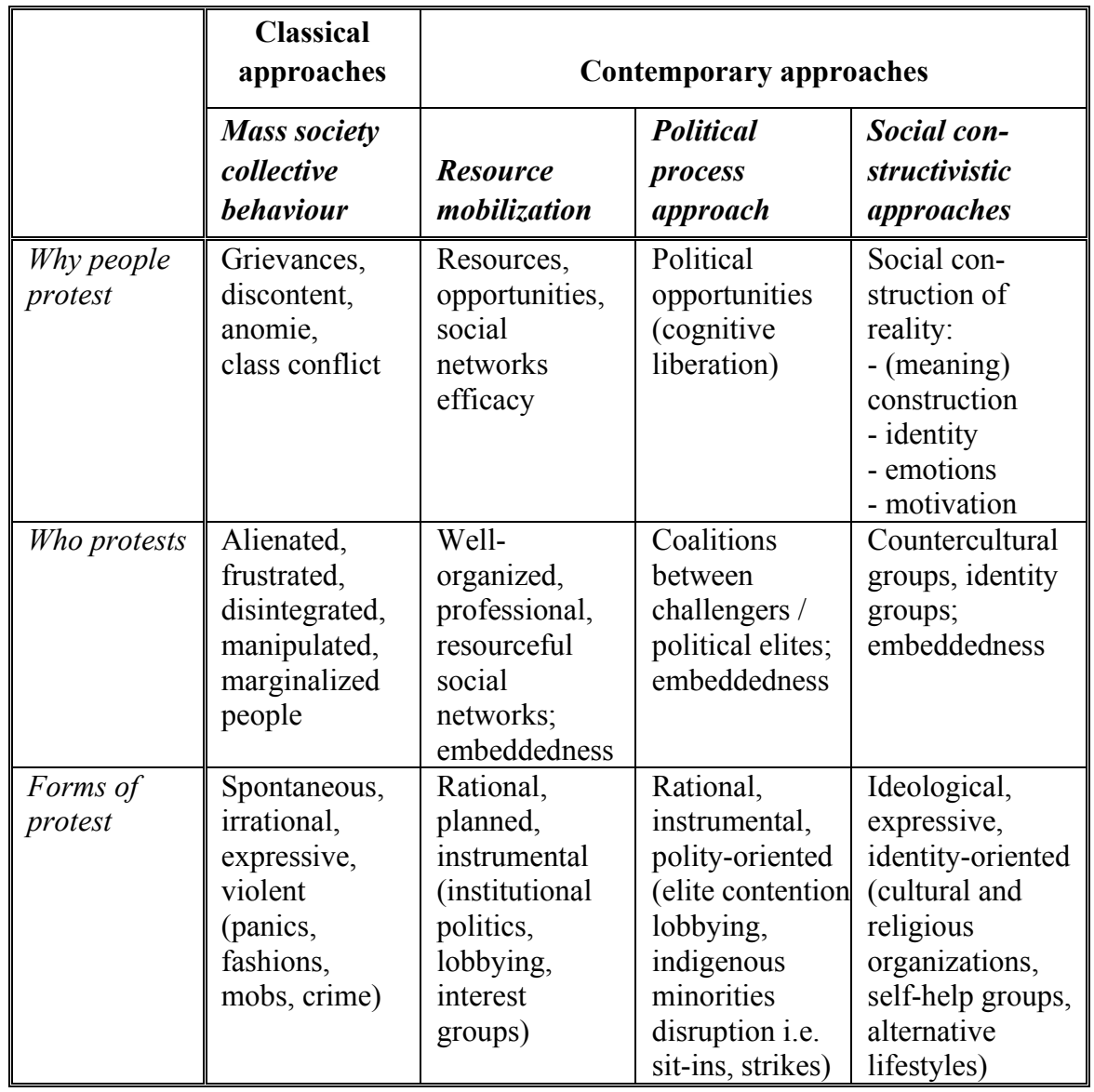

First however, we discuss the past and the present of social movement theory and sketch our subject of interest, namely social movements and collective action. There are numerous definitions of what a 'social movement' is. In this chapter a few definitions will be given, all departing from different theoretical angles and emphasizing different aspects of the phenomenon. A working definition of what we see as social movements and (their) collective actions is as follows: social movements are interlocking networks of groups, social networks 
and individuals, and the connection between them is a shared collective identity that tries to prevent or promote societal change by non-institutionalized tactics. ${ }^{6}$

\section{Breakdown and marginalization: The past}

Classical approaches, for example collective behaviour theory, mass society theory and relative deprivation, rely on the same general causal sequence moving from 'some form of structural strain (be it industrialization, urbanization, unemployment) [that] produces subjective tension and therefore the psychological disposition to engage in extreme behaviours such as panics, mobs etc. to escape from these tensions'. ${ }^{7}$ The various versions of classical approaches agree on this basic sequence and differ only in their conceptualization. To appreciate the similarities underlying these various formulations, let us briefly review a number of them.

Le Bon, as mentioned earlier, can be seen as the founding father of collective action studies and his ideas are reflected in several subsequent theories. He did not conceive of contentious politics in a very positive manner, perceiving crowds as primitive and irrational. He believed that individual members of a crowd become submerged in the masses, assuming a sense of anonymity and losing their sense of responsibility. Today, however, it is felt that Le Bon exaggerated the violent and irrational character of crowds.

Smelser ${ }^{8}$ and Blumer ${ }^{9}$ are viewed as breakdown theorists. Both held that political protest had its inception in tension and societal transition as a result of industrialization, urbanization and unemployment, and that it derived its motivational power from dissatisfaction with current forms of life. For Blumer, the motivating forces for collective action were, in addition to dissatisfaction and subsequent agitation, 'wishes' and 'hope' for a new scheme or system of living. In this way he dissociated himself from the notion that contentious politics were irrational acts rooted solely in agitation and frustration. Implicitly, in emotional terms, he depicted a rational, efficacious side to contentious politics. This perceived probability of making a difference was later described as 'cognitive liberation'. ${ }^{10}$

6 D. della Porta \& M. Diani (eds), Social Movements: An introduction (Basil Blackwell, Oxford, 1999).

7 D. McAdam, Political Process and the Development of Black Insurgency, 19301970 (University of Chicago Press, Chicago, 1982), p. 7.

8 Smelser, Theory of Collective Behavior.

9 H.G. Blumer, 'Collective behavior', in A. McClung Lee (ed.), Principles of Socio$\operatorname{logy}$ (Barnes and Noble Books, New York, 1969).

10 McAdam, Political Process and the Development of Black Insurgency. 
Kornhauser ${ }^{11}$ popularized the notion that people were vulnerable to the appeals of dictatorship because of a lack of restraining social networks. He argued that Nazism developed in Germany because Hitler was able to appeal directly to the people due to their alienation and anomie. This conforms to Putnam's more recent discussions of the alleged decline of social capita ${ }^{12}$ but stands in contrast to social movement studies that consistently show that it is people who are firmly embedded, rather than those who are alienated, who are politically active. ${ }^{13}$ Indeed, 'very little participation [is found] in either ordinary political activity or revolutionary outbursts by misfits, outcasts, nomads, the truly marginal, the desperate poor'. ${ }^{14}$

Gurr ${ }^{15}$ argued that when changing social conditions cause people to experience 'relative deprivation', the likelihood of protest and rebellion significantly increases. Feelings of relative deprivation result from comparisons of one's situation with some standard be it in one's own past or in someone else's situation, or some cognitive standard. ${ }^{16}$ If one concludes that one is not receiving the rewards or recognition one deserves, the feelings that accompany this assessment are referred to as relative deprivation. If people assess their personal situation, this is egoistic or individual deprivation; if they assess the situation of their group, it is called fraternalistic or group deprivation. It was assumed that fraternalistic relative deprivation was especially relevant in the context of movement participation. ${ }^{17}$

In conclusion, classical approaches tend to describe contentious politics as spontaneous, irrational, expressive and often violent outbursts of collective action in reaction to felt grievances, discontent and anomie. Protesters, according to classical approaches, are stressed, alienated, frustrated, deprived, disintegrated and marginalized individuals affected by economic crises, an unfair distribution of welfare, social rights, and normative breakdown.

11 W. Kornhauser, The Politics of Mass Society (The Free Press, London, 1995).

12 R. Putnam, Making Democracy Work: Civic traditions in modern Italy (Princeton University Press, Princeton, NJ, 1993).

13 McAdam, Political Process and the Development of Black Insurgency; B. Klandermans, J. van der Toorn \& J. van Stekelenburg, 'Embeddedness and grievances: Collective action participation among immigrants', American Sociological Review, 73 (2008), pp. 992-1012.

14 C. Tilly, The Contentious French (The Belknap Press of Harvard University Press, Cambridge, MA, 1986).

15 T. Gurr, Why Men Rebel (Princeton University Press, Princeton, NJ, 1970).

16 W.G. Runciman, Relative Deprivation and Social Justice (Routledge, London, 1966).

17 Ibid. 


\section{Resources, opportunities and meaning: The present}

With the growth in social movement activity on both sides of the Atlantic in the late $1960 \mathrm{~s}$, protest started to be perceived as positive and a way of improving politics. It was even seen as essential in a mature political system, rather than as threatening or undermining democracies. ${ }^{18}$ Social movement scholars of the 1970s and 1980s, who often happened to be activists themselves, were not persuaded by theories that labelled them as alienated, frustrated and disintegrated and their protest behaviour as irrational. They felt that the psychological makeup attributed to movement participants by the classical approaches did not fit them and argued that, if anything, movement participants were integrated rather than isolated. ${ }^{19}$ Clearly, the classical approaches failed to account for this outburst of social movement activity being seen as positive rational politics and preceded by a growth rather than a decline in welfare.

The changing perspectives on contentious politics and the growth of social movement activity in prosperous times made researchers in the US and Europe question where, if not from deprivation, social movement activity comes from. The answer was sought in different directions. In the US, structural approaches shifted attention from deprivation to the availability of resources, political opportunities and mobilizing structures to explain the rise of social movements, while in Europe, the social constructivistic 'New Social Movement' (NSM) approach focused attention on the growth of new protest potential, with grievances and aspirations resulting from the developing post-industrial society. ${ }^{20}$ While the structural approaches in the US tend to pay a great deal of attention to the how of collective action, the social constructivistic approaches in Europe attempt to explain why individuals are inclined to such actions. ${ }^{21} \mathrm{We}$ will explore these approaches in turn.

\section{Structural approaches}

Structural approaches investigate how characteristics of social and political context determine the opportunities or constraints for protest. These approaches reject grievances and ideology as the explanation for the rise and decline of movements. Structural approaches have always taken as their point of departure the fact that grievances are ubiquitous and that the key question in movement participation research is not so much why people are aggrieved, as why aggrieved people participate. Two main paradigms emphasize, firstly, the distri-

18 Ibid.

19 McAdam, Political Process and the Development of Black Insurgency.

20 B. Klandermans, H. Kriesi \& S. Tarrow (eds), From Structure to Action: Comparing social movement research across cultures, Vol. 1 (JAI Press, Greenwich, CT, 1988).

21 Ibid. 
bution of resources and the organizational characteristics of social movements ('resource mobilization') and, secondly, contextual factors such as the political and institutional environment ('political process').

Resource mobilization theorists wanted to move away from strong assumptions about the centrality of deprivation and grievances to a view that sees grievances as being a component - sometimes a secondary one - in the generation of social movements. ${ }^{22}$ Assigning grievances a subordinate position in theories explaining the rise and fall of social movements leads directly to an emphasis on mobilization processes or the dynamics and tactics of social movement growth, decline and change.

The resource mobilization approach examines the variety of resources that must be mobilized, the linkages of social movements to other groups, the dependence of movements upon external support for success, and the tactics used by authorities to control or incorporate movements. ${ }^{23}$

Resources can mean anything from material resources - jobs, income, savings and the right to specific goods and services - to non-tangible resources, such as authority, leadership, moral commitment, trust, friendship, skills and habits of industry. The reasoning goes that group conflict in its dynamic aspects can be conceptualized from the point of view of the mobilization of resources. Mobilization refers to the processes by which a discontented group assembles and invests resources for the pursuit of group goals. Conflict and change can be analyzed from the point of view of how resources are managed and allocated and the manner in which these resources can be redirected in the pursuit of group goals.

Resource mobilization scholars view social movements as a set of opinions and beliefs in a population that represents preferences for promoting or preventing social change. ${ }^{24}$ To predict the likelihood of preferences being translated into protest, the mobilization perspective focuses on pre-existing organization and the integration of those parts of a population that share the preferences. Social movements whose related populations are highly organized internally are more likely than others to spawn organized forms of protest. Resource mobilization theorists focus explicitly on the organizational component of activity. They argue that resources (money, labour, legitimacy, etc.) must be mobilized for action to be possible. The degree of activity directed towards the accomplishment of goals is perceived by resource mobilization theorists as a function of the resources controlled by an organization. In summary, people

22 J.D. McCarthy \& M.N. Zald, 'Resource mobilization and social movements: A partial theory', American Journal of Sociology, 82, 6 (1977), pp. 1212-1241.

23 Ibid., p. 1212.

24 Ibid. 
protest from a resource mobilization perspective because they are able to mobilize resources and feel politically successful. Prototypical protesters are rational, well-organized, professional and resourceful people who undertake wellplanned collective action with the goal of solving social problems.

Resource mobilization theory has not escaped criticism. It borrows its concept from the vocabulary of economics (the flow of resources, costs and benefits, supply and demand, organization, movement entrepreneurs, movement industries) and is particularly suited to the depiction of social movements such as rational entities weighing up the costs and benefits of their action. ${ }^{25}$ However, expressions such as 'costs and benefits' may make activists and scholars of social movements feel uncomfortable, as they convey notions of cold calculation being applied to social action which instead is often inspired by ideals and passion. But this is exactly the notion that resource mobilization theorists want to convey, namely that the ebb and flow of social movement activity results from the ability to mobilize resources and the perceived chances of success rather than from rising or declining grievance levels. In addition, it has been argued that resource mobilization theorists fail to acknowledge the strength of indigenous resources. For instance, McAdam shows that the growth of the black insurgency movement in America in the 1960s was related to 'injected' resources from elites but that indigenous resources such as informal networks providing solidarity, trust and leadership were important as well. ${ }^{26}$ Finally, 'resource mobilization theorists are to be faulted for their failure to acknowledge the power inherent in disruptive tactics' ${ }^{27}$ Piven and Cloward have argued that opportunities for protest occur when broad social changes and the restructuring of institutional life take place. Under such circumstances, the poor will take the opportunity to use the only power resource they have, namely protest. However, these 'extraordinary occurrences' that are 'required to transform the poor from apathy to hope, from quiescence to indignation, ${ }^{28}$ are limited in number. In normal circumstances, the struggle to survive takes up all the time and energy poor people have, and only when daily life severely breaks down does protest emerge.

While resource mobilization theorists explain the rise and fall of social movements by features internal to the movements themselves, such as the availability of resources and organizational aspects, political process theorists focus on external features, like changes or differences in the political and institutional environment of social movements. They argue that political environments vary

25 Ibid

26 McAdam, Political Process and the Development of Black Insurgency.

27 Ibid., p. 30.

28 F.F. Piven \& R.A. Cloward, Poor Peoples' Movements: Why they succeed, how they fail (Random House, New York, 1977), p. 14. 
over time and between areas. The paradigm proposes changes in or differences between political structures as the main explanation for the rise and fall of social movements and that differences from one country or era to another stem from the process by which a national political system shapes, checks and absorbs the challenges confronting it. ${ }^{29}$

Three ideas are central to the political process approach: first, a social movement is a political rather than a psychological phenomenon; second, a social movement represents a continuous process from its creation to its decline rather than a discrete series of developmental stages; and third, different forms of action ('repertoires of contentions') are associated with different spatial and temporal locations. ${ }^{30}$ For Tilly, one of the leading theorists of the political process approach, action repertoires are specific actions such as riots, demonstrations, strikes, sit-ins, petitioning or lobbying that are carried out by collective actors over a specific period of time. Tarrow expands this concept and suggests that 'actions are not only what people do when they are engaged in conflict with others, it is what they know how to do and what others expect them to do'. ${ }^{31}$ The form of action chosen by social movements depends on factors including the structure of the political system (e.g. democratic institutions, the existence and structure of political parties, and possibilities for direct participation), the level of repression, and cultural traditions. The actions of social actors are, therefore, not purely random. Instead, action repertoires are shaped by structural variables and the cultural context in which they originate.

By studying the changing action repertoires in France over the last four centuries, Tilly ${ }^{32}$ demonstrated that social movements draw on action repertoires that develop over long periods and change in conformity in an evolving context. If a prevailing repertoire of contention changes significantly at some point, the change is a symptom of a substantial alteration in the structure of power. An expansion of the state in nineteenth-century France, including a nationalization of politics, was, for instance, accompanied by a major change in the repertoire of collective action. The more spontaneous tax rebellions and bread riots aimed at the local authorities more or less disappeared and were replaced by more coherent forms of contention. The centralization of the state played an essential part in the creation of modern social movements with a

29 C. Tilly, 'Social movements and national politics', in: C. Bright \& S. Hardine (eds), Statemaking and Social Movements: Essays in history and theory (University of Michigan Press, Ann Arbor, MI, 1984).

30 Tilly, The Contentious French.

31 S. Tarrow, Power in Movement: Collective action, social movements and politics (Cambridge University Press, Cambridge, 1994), p. 31.

32 Tilly, The Contentious French. 
repertoire that is still present today: the strike, the demonstration, and the protest meeting.

Tarrow $^{33}$ studied the cycle of protest that swept across Italy from the late 1960s through the early 1970s and showed how protest spread from students' and workers' movements to virtually every sector of Italian society and gave rise to extra-parliamentary groups, violence and, finally, a return to traditional political patterns. In other words, by utilizing the political opportunities offered by the system, social movements create an ideologically and socially favourable environment for new social groups to mobilize.

Political structures have also explained differences in protest activity between countries. ${ }^{34}$ For instance, the protest repertoire of social movements in Switzerland that were struggling within a direct democracy appeared to be more moderate than the radical repertoire employed by French social movements fighting their cause in a closed democracy. ${ }^{35}$ To strengthen the case for the argument that direct democratic procedures have a moderating effect on the action repertoires of social movements, Kriesi and Wisler ${ }^{36}$ showed that within one country, the Swiss federal state, differences between Swiss cantons regarding direct democratic procedures had an impact on the action repertoires employed within these cantons. The German-speaking cantons were more open than the Latin ones and, not surprisingly, social movements based in the German cantons employed a less radical action repertoire than their Latin counterparts.

McAdam is a political process theorist who, while emphasizing structural aspects of the environment, also focuses on subjectivity. He explained the rise and fall of the civil-rights movement in the United States between 1930 and 1970 with reference to political opportunities, political efficacy and institutions like black churches and black colleges. ${ }^{37}$ While classical theorists saw a direct link between social instability and political insurgency, McAdam saw only an indirect relationship, as illustrated in Figure 1.

McAdam argues that two necessary conditions need to be in place to turn social instability into political insurgency: (i) available resources and open

33 S. Tarrow, Democracy and Disorder: Protest and politics in Italy 1965-1975 (Clarendon Press, Oxford, 1989).

34 P. Eisinger, 'The conditions of protest behavior in American cities', American Political Science Review, 67 (1973), pp. 11-15.

35 H. Kriesi, R. Koopmans, J.W. Duyvendak \& M. Giugni, New Social Movements in Western Europe (University of Minnesota Press, Minneapolis, MN, 1995).

36 H. Kriesi \& D. Wisler, 'Direct democracy and social movements in Switzerland', European Journal of Political Research, 30 (1996), pp. 19-40.

37 McAdam, Political Process and the Development of Black Insurgency, p. 7. 
Figure 1 McAdam's 1982 political process model

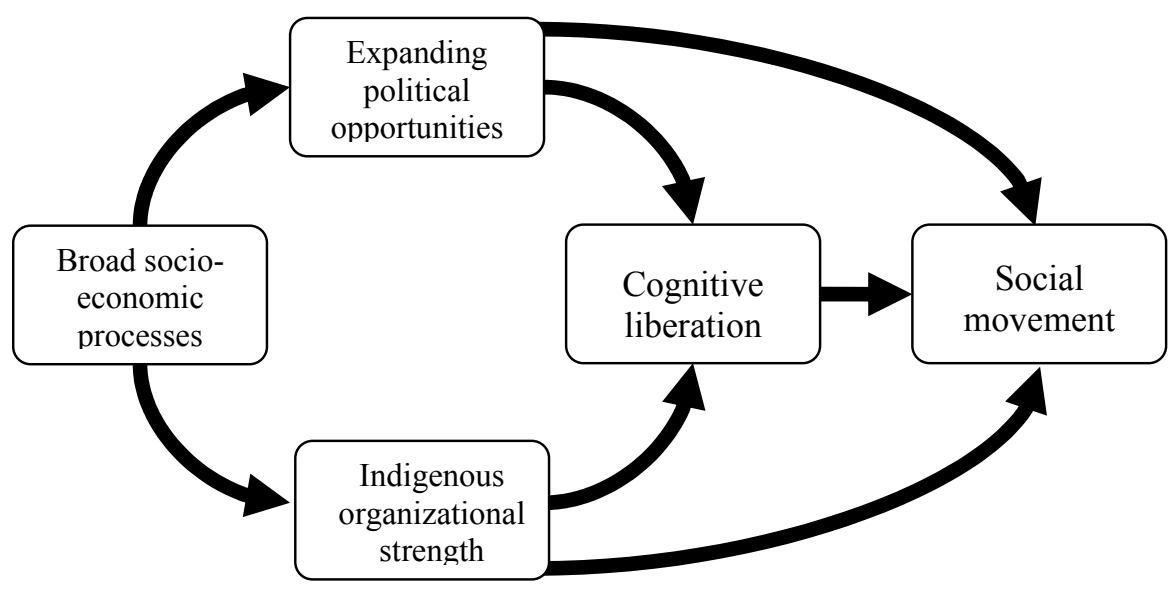

political opportunities, and (ii) cognitive liberation. Although the political process model builds upon the resource mobilization approach, in contrast to this approach, it also takes the indigenous organizational capabilities of aggrieved populations into account. The second condition, that of cognitive liberation, proposes that the subjectivity of actors makes resources usable and collective action viable, and helps actors and groups to frame their situation as unjust and liable to change. ${ }^{38}$ Political opportunities and organization alone do not produce social movements. Mediating between political opportunities and organizational strength are people and their hopes and fears. In general, the political process approach argues that the ebb and flow of movement activity is related to the opening up and closure of political opportunities. Protesters are rational, instrumental, polity-oriented people who seize opportunities by lobbying and forming coalitions with political elites.

Several studies make a convincing case for the political process approach but some fail to explain political protest, and others show that the approach is more effective in one context than another. The lack of theory concerning the specific mechanisms that link political process to movement activity is identified as the fundamental problem in explaining these divergent results. ${ }^{39}$ Moreover, incen-

38 Piven \& Cloward, Poor Peoples' Movements.

39 R. Koopmans, 'The missing link between structure and agency. Outline of an evolutionary approach to social movements', Mobilization, 10 (2005), pp. 19-36. 
tives and expectations necessarily involve interpretation, just like opportunities and constraints. ${ }^{40}$ Indeed, if there were a perfect correlation between objective and subjective environments, there would be no need to distinguish between the two, whereas research suggests that this is often not the case. ${ }^{41}$

\section{Social constructivistic approaches}

The development of social movement activity in the prosperous times of the second half of the twentieth century shows differences between the US and Europe. While there was an emphasis in the US on structural aspects such as resources and political opportunities, answers were formulated in Europe in terms of new constituencies with new needs, values and aspirations arising from developing post-industrial societies, producing what were dubbed New Social Movements. This 'NSM approach' argued that processes of modernization created two groups of constituencies. The first were groups that had lagged behind due to marginalization processes related to industrial modernization (youth, women and the elderly were especially seen as groups threatened by the automation of productive work). The second were groups with a specific vulnerability resulting from modernization processes. ${ }^{42}$ In particular, the post-war generation, whose material needs were satisfied, developed post-material values from which emerged such new needs and aspirations as self-actualization and participation. ${ }^{43}$ This group came into conflict with a political and social system that was chiefly materialistic. The NSM approach was social constructivistic in emphasizing social changes in identity, lifestyle and culture. NSM scholars utilized identity as their core concept, with Melucci arguably being the most explicit. ${ }^{44} \mathrm{He}$ thought collective identity "bridge[s] the gap between behavior and meaning, between "objective" conditions and "subjective" motives and orientation, between "structure" and "agency". ${ }^{45}$

However, social constructivistic approaches were not an exclusively European matter and the hegemony of structural approaches in the US began to be

40 J. Goodwin \& J.M. Jasper, 'Caught in a winding, snarling vine: The structural bias of political process theory', Sociological Forum, 14, 1 (1999), pp. 27-54.

41 B. Boyd, G.G. Dess \& A. Rasheed, 'Divergence between archival and perceptual measures of the environment: causes and consequences,' Academy of Management Review, 18, 2 (1993), pp. 204-226.

42 Klandermans, Kriesi \& Tarrow, From Structure to Action.

43 R. Inglehart, The Silent Revolution: Changing values and political styles among Western publics (Princeton University Press, Princeton, NJ, 1977).

44 A. Melucci, Nomads of the Present: Social movement and identity needs in contemporary society (Temple University Press, Philadelphia, PA, 1989).

45 A. Melucci, Challenging Code (Cambridge University Press, Cambridge, 1996), p. 69. 
challenged in the mid 1980s. ${ }^{46}$ The social constructivistic perspective concentrates on questions of how individuals and groups perceive and interpret material and socio-political conditions. Social constructivists argue that if we want to understand why people protest, we need to know how they perceive and interpret their social-political context. A number of European and US social movement scholars with social-psychology backgrounds called for attention to be paid to meaning and its construction and identity. They referred to explanations founded in emotion, such as interpretation, symbolization and meaning, and to social-psychology expansions of structural approaches such as resource mobilization. ${ }^{47}$ They argued that structural explanations are limited because individuals who are in the same structural position do not display identical behaviour. A shared position can never provide sufficient explanation of individual behaviour. ${ }^{48}$ Even if people display identical behaviour, their motivational background and their accompanying emotions may still be different. ${ }^{49}$

This social constructivistic approach draws on past views but is not a return to the classical approaches of the 1950s. While both classical and social constructivistic approaches recognize that emotions and cognition are important to collective action, the classical approaches see them as pathological, whereas social constructivistic approaches perceive them as the normal, ubiquitous aspects of social and political life. Social constructivistic approaches try to understand why people who are seemingly in the same situation respond so differently. They question why some people feel ashamed of their situation, while others take pride in it; why some are aggrieved, while others are not; why some define their situation as unjust, while others do not; why some feel powerless, while others feel empowered; and why some are angry, while others are afraid. These are the issues that social constructivistic approaches to social movements seek to answer. We now turn to meaning (or construction), identity, and emotional and motivational explanations as examples of contemporary social constructivistic approaches.

46 R. Benford, 'An insider's critique of the social movement framing perspective', Sociological Inquiry, 67, 4 (1997), pp. 409-430.

47 B. Klandermans, 'Mobilization and participation: Social-psychological expansions of resource mobilization theory', American Sociological Review, 49, 5 (1984), pp. 583-600.

48 D. Snow \& P. Oliver, 'Social movements and collective behavior: Social psychological considerations and dimensions', in: K.S. Cook, G.A. Fine \& J.S. House (eds), Sociological Perspectives on Social Psychology (Allyn and Bacon, Boston, MA, 1995).

49 J. van Stekelenburg \& B. Klandermans, 'Individuals in movements: A social psychology of contention', in: B. Klandermans \& C.M. Roggeband (eds), The Handbook of Social Movements Across Disciplines (Springer, New York, 2007). 
The first involves the meaning that people attach to their social environment. This is the direct or indirect subject of investigation by students of protest. Perceptions are not fixed but are susceptible to interpretation and thus play a role in the construction of meaning. ${ }^{50}$ And participation in collective action thus depends not only on perceptions of structural strain, availability and the deployment of material resources, the opening up or closing of political opportunities or a cost-benefit calculation more generally but also on the way these variables are constructed and framed and the degree to which they resonate with targets of mobilization. ${ }^{51}$

Social movements play a significant role in the diffusion of ideas and values to the extent that some scholars see the construction of meaning as a movement's primary function. ${ }^{52}$ Through processes such as consensus mobilization ${ }^{53}$ or framing, ${ }^{54}$ activists seek to disseminate their definition of a situation to the public at large. Participating because of common interests or ideologies requires a shared interpretation of who should act, and why and how. Movements affect such interpretations by the information they disseminate, a process known as 'framing'. Social movements do their utmost to communicate how they interpret a social, political or economic change (its diagnosis) and what should be done (the prognosis) as a reaction to perceived losses or unfulfilled aspirations. ${ }^{55}$ The more individual orientations, values and beliefs become congruent with activities, goals and ideologies of social movement organizations, the greater the level of sharedness. Gerhards and Rucht's study ${ }^{56}$ of flyers produced by the various groups and organizations involved in protests against the International Monetary Fund (IMF) and the World Bank in Berlin is an excellent example in this respect. The researchers showed how links were constructed between the ideological framework of the organizers of the demonstration and those of the participating organizations to create a shared definition of the situation.

With regard to social identity, the clearest definition that has been located in the social-psychology literature is presented by Tajfel and Turner. According to

50 W.A. Gamson, Talking Politics (Cambridge University Press, Cambridge, 1992).

51 D.A. Snow, E.B. Rochford, S.K. Worden \& R.D. Benford, 'Frame alignment processes, micromobilization, and movement participation', American Sociological Review, 51 (1986), pp. 464-481.

52 R. Eyerman \& A. Jamison, Social Movements: A cognitive approach (Polity Press, Cambridge, 1991).

53 Klandermans, Kriesi \& Tarrow, From Structure to Action.

54 Snow et al., 'Frame alignment processes'.

55 Ibid.

56 J. Gerhards \& D. Rucht, 'Mesomobilization: Organizing and framing in two protest campaigns in West Germany’, American Journal of Sociology, 98, (1992), pp. 555596. 
them, identity is 'that part of an individual's self-concept which derives from his knowledge of his membership of a social group (or groups) together with the value and emotional significance attached to that membership, ${ }^{57}$ Hence a social identity makes people think, feel and act as members of that specific group. But people have many social identities. Why do some social identities become central to mobilization while others do not? Probably the most powerful factor that brings group membership to mind is conflict or rivalry between groups, and in times of inter-group conflict, people are inclined to take to the streets on behalf of their group.

Collective action is a group rather than an individual phenomenon but in the end it is individuals who decide whether or not to participate. This raises the question of what connects the individual to the collective. Identification with the group involved seems to be the answer. The influence of identification processes on protest participation refers to the circumstances in which people identify with the others involved. People participate not so much because of the outcome associated with participation but because they identify with the other participants. Group identification changes the focus from what 'I' want to what 'we' want. Collective action participation is seen as a way to show who 'we' are and what 'we' stand for, and people experience commitment and solidarity with other members of the group. In addition, group members have the idea that 'we' have much in common (by way of shared grievances, aims, values or goals). Group identification seems to be a powerful reason for participating in protest. ${ }^{58}$

Little is known about the influence of emotions on protest behaviour. Yet it is acknowledged that emotions permeate all the stages in social movement participation: recruitment, staying in and dropping out. Emotions function as accelerators or amplifiers, ${ }^{59}$ making things move more quickly or sound louder. In the world of protest, 'accelerating' means that one's motives for joining, staying in or leaving a social movement translate into action more quickly due to emotions, while 'amplifying' means that these motives become stronger. Few researchers have focused on the complex emotional processes that channel fear and anger into moral indignation and political activity. Those of us who have been part of protest events or have watched reports on protest events in the media may find this hard to believe. However partly as a reaction to the classi-

57 H. Tajfel \& J.C. Turner, 'An integrative theory of intergroup conflict', in S. Worchel and W.G. Austin (eds), The Social Psychology of Intergroup Relations (Brooks/ Cole, Monterey, CA, 1979), p. 63.

58 For overviews, see S. Stryker, T.J. Owens \& R.W. White (eds), Self, Identity, and Social Movements (Minnesota Press, Minneapolis, MN, 2000) and N. Ellemers, R. Spears \& B. Doosje (eds), Social Identity: Context, commitment, content (Blackwell Publishers, Oxford, 1999).

59 Van Stekelenburg \& Klandermans, 'Individuals in movements'. 
cal approaches that stressed the irrational character of movement participation and partly because they are complicated phenomena, emotions have not featured prominently in the social movement literature. Even 'affective' phenomena such as moral shocks ${ }^{60}$ or suddenly imposed grievances ${ }^{61}$ have been primarily approached from a cognitive point of view. But all demands for change begin with discontent. Emotions warn people of threats and challenges and propel behaviour. Moreover, affective measures, such as affective commitment ${ }^{62}$ and injustice, ${ }^{63}$ have the biggest impact on behaviour. Thus if one wants to understand engagement in collective action, one must understand the workings of emotions.

Goodwin, Jasper and Polletta argue that emotions are socially constructed but that 'some emotions are more [socially] constructed than others, involving more cognitive processes' ${ }^{64}$ In their view, emotions that are politically relevant are at the social construction end of the scale. For these emotions, cultural and historical factors play an important role in the interpretation (i.e. perception) of the state of affairs by which they are generated. Obviously, emotions can be manipulated. Activists work hard to create moral outrage and anger and to provide a target against which these can be vented. They have to weave a moral, cognitive and emotional blanket of attitudes. Framing theory has provided a way to link ideas and the social construction of ideas with organizational and political process factors. These studies, however, deal almost entirely with the cognitive components of frames and neglect any emotional components. Powerful frames might, however, be related to the values and emotions that they contain and it might be argued that frames not only resonate cognitively but also emotionally.

These issues are all related to questions of motivation. Demands for change are rooted in a notion of belonging (identity) and experienced grievances (constructed meaning) in combination with emotions related to a specific grievance. Although, typically, many members of disadvantaged groups are dissatisfied with their collective situation and strongly sympathize with the goals of collective actions, often only a small proportion actually participate in protest to

60 J.M. Jasper, The Art of Moral Protest (University of Chicago Press, Chicago, IL, 1997).

61 E.J. Walsh, 'Resource mobilization and citizen protest in communities around Three Mile Island', Social Problems, 29, 1 (1981), pp. 1-21.

62 Ellemers et al., Social Identity.

63 T.R. Tyler \& H.J. Smith, 'Social justice and social movements', in D.T. Gilbert \& S.T. Fiske (eds), Handbook of Social Psychology, $4^{\text {th }}$ ed. (McGraw-Hill, Oxford, 1998).

64 J. Goodwin, J.M. Jasper \& F. Polletta, Passionate Politics: Emotions and social movements (The University of Chicago Press, Chicago, IL, 2001), p. 13. 
achieve these goals. ${ }^{65}$ In collective action research therefore, the motives underlying participation have become a key issue. ${ }^{66}$

Over the last two decades, social psychologists have investigated the motives behind participation and demonstrated that instrumental reasoning, identification, emotions and ideological factors form a motivational constellation in response to the question about why people participate in contentious politics. ${ }^{67}$ Interestingly though, this motivational constellation seems to be context dependent: Van Stekelenburg, Klandermans and van Dijk ${ }^{68}$ for instance, showed that, in demonstrations organized by a labour movement, people tend to be instrumentally motivated whereas demonstrators against neoliberalism are more ideologically motivated. In more general terms, people are inclined to take the instrumental path if a conflict is framed in terms of material interests and the ideological path if it is framed in terms of conflicting principles.

In conclusion, social constructivistic approaches argue that protesters live in a perceived reality and that threats and opportunities are socially constructed and/or framed by social movements and other social and political actors. Group identification plays a key role in what protesters think, feel and do and protesting is as rational or irrational as all social behaviour. People participate therefore not only in collective action for instrumental reasons but also because they identify with others involved or because they want to express their anger and indignation at a target if they believe that their values have been violated. Social constructivistic approaches investigate how perceptions, emotions and identities shape a person's motivation to take part in contentious politics. There appears to be a great deal of merit in utilizing social constructivistic approaches alongside structural approaches when studying contentious politics. However, social constructivistic approaches are characterized by their variety. They have four key themes - the construction of meaning, identity, emotions and motivation - but a common framework to allow the integration of these variables is clearly missing. Social constructivistic studies tend to consist of single case-studies that inevitably have little to say about contextual variation. However, one needs to understand the characteristics of the socio-political and mobilizing context to make sense of the findings in a specific country or period of time. This requires comparative studies rather than single case-studies.

65 G. Marwell \& P. Oliver, The Critical Mass in Collective Action: A micro-social theory (Cambridge University Press, Cambridge, 1993); Klandermans, The Social Psychology of Protest.

${ }_{66}$ Ibid.

67 Ibid.

68 J. van Stekelenburg, B. Klandermans \& W.W. van Dijk, 'Context matters: Explaining why and how mobilizing context influences motivational dynamics', Journal of Social Issues (forthcoming, 2009). 
The social constructivistic approach thus runs the risk of fragmentation and decontextualization. In an attempt to bridge the gap between the objective existence of the opportunities and resources in the environment, as opposed to the protesters' subjective perception, social constructivistic approaches clearly need a common framework that integrates key themes and takes the socio-political context into account.

\section{Contextualized contestation: The prospects}

In the rapidly globalizing world of the network society and the information society, ${ }^{69}$ streams of migration are creating diasporas in which flows of ideas and resources are influencing contentious politics in both their homelands and in their host countries. At the same time, globalization has resulted in more transnational and supranational political institutions such as the European Union, the United Nations and the IMF that are having an ever-increasing impact on people's daily lives. Some scholars believe they can detect the emergence of a new social fabric, which they have baptized the "network society', ${ }^{70}$ arguing that networks have become the prime mode of organization and structure of society. Formal organizations have turned into networks of networks, which in turn are intersected with informal networks rooted in personal life worlds and more diffuse interpersonal group settings. The logic of the network society pervades all spheres of social, economic and cultural life. ${ }^{71}$ In addition, new communication technologies are giving rise to the information society, ${ }^{72}$ as new technologies intensify societal change and pace. As Held puts it:

... what is new about the modern global system is the chronic intensification of patterns of interconnectedness mediated by such phenomena as the modern communication industry and new information technology and the spread of globalization in and through new dimensions of interconnectedness. ${ }^{73}$

It should be noted that Held made his statement at a time when the real communication revolution was still to come.

69 M. Castells, The Rise of the Network Society (Blackwell Publishers, Oxford, 1996); H. Rheingold, Smart Mobs: The next social revolution (Perseus, Cambridge, MA, 2002); B. Wellman, 'The network community', in B. Wellman (ed.), Networks in the Global Village (Westview, Boulder, CO, 1999), pp. 1-48; R.K. Garrett, 'Protest in an information society: A review of literature on social movements and new ICTs', Information, Communication, and Society, 9, 2 (2006), pp. 202-224.

70 Castells, The Rise of the Network Society.

71 Ibid.

72 Garrett, 'Protest in an information society'.

73 D. Held, 'Democracy, the nation-state and the global system', in David Held (ed.), Political Theory Today (Polity Press, Cambridge, 1991), p. 145. 
Societies are changing fundamentally and this affects contentious politics. After all, information and networks are essential elements of mobilization and one could assume that such profound changes must be having an impact on the dynamics of contention. And as a result of these transformations, the field of contentious politics has changed significantly. ${ }^{74}$ Protest as a political tactic has diffused across a range of constituencies and claims. Contributing to and resulting from such diffusion is an increased tolerance for protest so that engaging in political protest is no longer stigmatized. Moreover, protest in Western democracies has generally been an effective tool for politically disadvantaged groups both on the left and the right. ${ }^{75}$ This conveys the message that the tactic is not only legitimate but also effective. Simply because more citizens have protested more frequently and on more diverse issues, more experienced protesters are available for subsequent protest calls. ${ }^{76}$ The legitimacy of protest, its proven efficacy and the ample experience of protest among citizens will all influence the dynamics of contention.

\section{Changing society, changing paradigms?}

Perhaps more than in any other sector of comparative politics, the study of contention is sensitive to developments in the real world. ${ }^{77}$ We therefore assume that, just as in the 1960s, contemporary changes in society will give rise to new approaches. Contentious politics is a multi-faceted phenomenon with sociopolitical, organizational and social-psychology roots. To investigate who rebels and on what issues requires inclusive models. Yet the connection between structures that canalize grievances into contentious politics is a thorny but relatively underexposed issue in the protest literature.

This observation is not new. In 1988 Klandermans, Kriesi and Tarrow suggested a research agenda with the emphasis on comparative research and the integration of structural, cultural and motivational factors. ${ }^{78}$ Their book was the first tangible outcome of a prolonged exchange between representatives of the

74 D. della Porta \& S. Tarrow (eds), Transnational Protest and Global Activism (Rowman and Littlefield, Lanham, MD, 2005).

75 W.A. Gamson, Strategy of Social Protest (Wadsworth Publishing, Belmont, CA, 1990).

76 V. Taylor, 'Mobilizing for change in a social movement society', Contemporary Sociology, 29, 1 (2000), pp. 219-230; Meyer \& Tarrow, Towards a Movement Society?

77 D. McAdam, S. Tarrow \& C. Tilly, 'Comparative perspectives on contentious politics', in: M. Lichbach \& A. Zuckerman (eds), Ideas, Interests and Institutions: Advancing theory in comparative politics (Cambridge University Press, Cambridge, 2007).

78 Klandermans, Kriesi \& Tarrow, From Structure to Action. 
American and European approaches and this resulted in an increasingly closely knit network of contacts across the Atlantic that was instrumental in organizing a series of conferences and edited volumes. In 1996 a book edited by McAdam, McCarthy and Zald ${ }^{79}$ was released with a widely shared synthesis of three broad sets of factors to analyze the emergence and development of social movements: the structure of political opportunities and constraints confronting the movement; mobilizing structures; and framing processes. Two additional synthesizing efforts came in 1999 from Della Porta and Diani ${ }^{80}$ and in 2004 from Snow, Soule and Kriesi, ${ }^{81}$ all of whom drew together political opportunity, movement framing and the social network theory. So although social constructivistic approaches are usually framed as being opposed to structuralist accounts, the contemporary research agenda calls for an integration of structural, political and sociological theories of movements with social constructivistic approaches rooted in social psychology and cultural sociology. Yet research agendas focusing on comparative research and theoretical syntheses of structure and agency are as relevant today as they ever were. To be sure, theories of contentious politics are currently more sophisticated than previously but many questions remain unresolved, such as how the political and mobilizing context 'translates' into contentious politics. These questions require interdisciplinary and comparative studies. Such studies have not featured prominently in the social movement literature, perhaps because truly interdisciplinary and comparative studies are so complex. Therefore, the question as to how characteristics of socio-political structure might translate into action is as relevant now as it was in 1988 when Klandermans, Kriesi and Tarrow first drew attention to it.

An explanatory framework, which we developed in collaboration with Stefaan Walgrave, might be useful here because it highlights precisely the interaction between structure and action as its point of departure. It crosses interdisciplinary boundaries that connect the micro level of individual protesters with the meso level of social movements, and the macro level of national political systems and supranational processes. We started from the notion that the answer to questions such as who protests, why people protest (i.e. the issues) and the forms of contention (e.g. grassroots activity, civil war) lies in the interaction of supranational processes, political processes at the national level and the mobilizing context (see Figure 2).

What follows elaborates on contextual variation. Given that this is a chapter in a book on social movements in Africa, the framework will be discussed

79 D. McAdam, J.D. McCarthy \& M.N. Zald (eds), Political Opportunities, Mobilizing Structures, and Cultural Framings (Cambridge University Press, New York, 1996).

80 Della Porta \& Diani, Social Movements.

81 D.A. Snow, S.A. Soule \& H. Kriesi (eds), The Blackwell Companion to Social Movements (Blackwell Publishing, Oxford, 2004). 
against the background of the continent's (contextualized) contestation. Conflict in Africa is still widespread and tenacious and is often rooted in material poverty, scarcity, ecological decline and inequality. Inter-group conflicts are partly related to historical and current international engagements in Africa but also emanate from local tensions and the workings of unequal and corrupt socio-political systems. These international, national and local conflicts translate into and shape daily life and have long-term effects that fuel conflict in new forms. Indeed, if anything, Africa is the continent in which to observe contextualized contestation.

Figure 2 Contextualized contestation

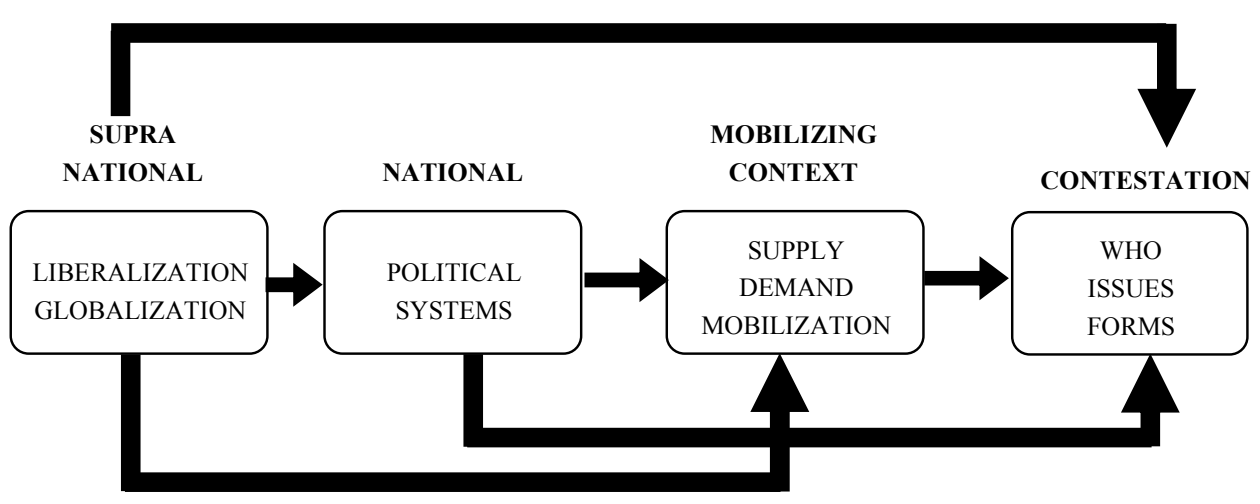

Supranational processes. It is increasingly important these days to take the international dimensions of contestation into account and this is certainly true in Africa. First, political and economic liberalization processes have had a profound impact and perhaps even a certain causative influence on the emergence of new social movements or the transformation of existing ones. Second, sociopolitical changes, shaped by donor-country pressure, global regimes of development policies or ideals and democratization, human-rights discourses and religious expansion appear to have a crucial impact on contestation in Africa. And third, streams of migration have created diasporas in which flows of ideas and resources such as money and organizational experience, but also education, influence the mobilizing structure and thus contentious politics in migrants' home countries. These wider processes of liberalization and globalization (both in terms of influx and outflux) have influenced national political systems, shaped mobilizing structures and had an impact on contentious politics in Africa in ways that remain largely unclear. 
In the social movement literature, it is increasingly acknowledged that social movement activity is evolving in response to processes of globalization, ${ }^{82}$ and how contention is moving from the national to the transnational level is being examined. ${ }^{83}$ Scholars have identified, for instance, the mechanisms and paths along which this scale shift is occurring ${ }^{84}$ the close relationship between global governance institutions, nation states and transnational social movements, ${ }^{85}$ and the multilayered opportunity structures in which movements operate nowadays. ${ }^{86}$ Briefly, all these studies show that the socio-political context in which movements operate to spread their aims and ideas is not simply national or only supranational but there is a mix of supranational, national and local influences.

National processes. Countries vary in terms of the circumstances they create for contentious politics. The political opportunity structure, the openness of the political system for challengers, the access points available for people to defend their interests and express their opinions and the temporal political configuration have all been identified as determinants of the incidence and type of protest in democratic polities. ${ }^{87}$ With regard to Africa, states are often said to be failing, levels of democratization tend to be low and many are being led by corrupt dictators. Apart from pervasive misgovernance and gross abuses of state power, the nature and role of 'ungoverned political spaces' across the continent is poorly understood: how do they enhance conflict and translate it into contentious politics? Although the social movement literature is quite elaborate as far as the effects of repression are concerned, little is yet known about the influence of supranational processes on contention within a state. How do, for instance in Zimbabwe which is arguably one of the world's most repressive states, international lobbies, boycotts, the absence of food and medical care or resources provided by diasporas create chances for social movements to prevent or promote social change? While misgovernance or non-governance, failing states, repression and corruption are not unique to Africa, their direct political impact is probably greater than elsewhere, inhibiting institution-building, development and the fair distribution of resources. Again it remains a question of how the

82 D. della Porta, H. Kriesi \& D. Rucht (eds), Social Movement in a Globalizing World (Macmillan, London, 1999); Della Porta \& Tarrow, Transnational Protest and Global Activism.

83 S. Tarrow \& D. McAdam, 'Scale shift in transnational contention', in: Della Porta \& Tarrow, Transnational Protest and Global Activism.

84 Ibid.

85 M. Keck \& K. Sikkink, Activists beyond Borders: Advocacy networks in international politics (Cornell University Press, Ithaca, NY, 1998).

86 Ibid.

87 R. Koopmans, 'Political. Opportunity. Structure. Some splitting to balance the lumping', Sociological Forum, 14 (1999), pp. 93-105; Tarrow, Democracy and Disorder: Protest and politics in Italy. 
sphere of governance, politics, power and the state in specific countries influences the mobilizing context and the quality and extent of contentious politics.

Mobilizing context. The mobilizing context in a country can be described in terms of supply, demand and mobilization. ${ }^{88}$ While the demand side of protest refers to the protesters' potential in a society; the supply side refers to the characteristics of the social movement sector in a society. Mobilization refers to the techniques and mechanisms that link supply and demand. We will consider these factors one by one.

A demand for protest begins with levels of grievance in a society. ${ }^{89}$ The deep insecurities of life in many African countries - ecological, material, social, political and health-related (notably due to AIDS) - may have a direct impact on perceived grievances and thus on conflict behaviour. New religious identities are also developing in some forms and settings, resulting in radical contentious politics. In addition, it seems plausible that a demand for change is defined by the diasporas as well. How these grievances are shaped by the (supra)national context and translated into demand for protest is an interesting but so far unanswered question. Even less is known about the role of the mobilizing context as translator, facilitator and organizer of ethnic conflict, religious confrontations and resource-related conflicts. Why do certain grievances end up in contentious politics that originate in conflicting principles while others end up in contentious politics originating in conflicting material interests?

With regard to the supply side of contentious politics, this concerns the characteristics of the social movement sector in a society, its strength, diversity and contentiousness. Traditionally, the social movement sector is conceived of as a conglomerate of movement organizations, such as trade unions, associations, liberation movements or civil-society organizations, ${ }^{90}$ that provide the more or less formalized infrastructure from which contentious politics is built. ${ }^{91}$ Increasingly however, we are seeing protest participation rooted in every-day networks of participants and social movement actors involved in diffuse and decentral-

88 B. Klandermans, 'The demand and supply of participation: Social-psychological correlates of participation in social movements', in Snow et al., The Blackwell companion to social movements (Blackwell Publishing, Oxford, 2004).

89 Klandermans, The Social Psychology of Protest.

90 McAdam et al., Political Opportunities, Mobilizing Structures, and Cultural Framings.

91 M. Diani \& D. McAdam (eds), Social Movement Analysis: The network perspective (Oxford University Press, New York, 2003); D. McAdam, Freedom Summer (Oxford University Press, New York, 1988); McCarthy \& Zald, 'Resource mobilization and social movements'. 
ized networks. ${ }^{92}$ How does the political system (repressive or otherwise) shape the supply side? Is it because of repression and/or bans on open mobilization that organizations go underground and turn into loose networks? Egypt and Yemen, where inclusive informal social networks (rather than formal organizations) are an essential mechanism for spreading Islamist ideas, ${ }^{93}$ offer examples. Does religious identification influence the political arena in divided countries with a failing political system (e.g. Nigeria) as religious community leaders create alternative routes for mobilization? What do activists and political actors of a previous generation do after their 'projects' have ended in success or failure? Examples here are the evolution of the former leaders and membership of anti-apartheid movements in South Africa and their changing careers. These political actors emanated from social movements and have transformed them. ${ }^{94}$ How do social movements and actors evolve in current post-colonial African conditions shaped by liberalization and globalization? How do, for instance, large resourceful organizations, like the UN, with their influential global justice, human rights and democratization framework shape and influence the supply side? Globalization in Africa also entails the rapidly growing role of China (and other Asian countries) on the continent and often evokes counter-responses by Africans.

Finally, processes of mobilization bring demands for protest together with a supply of protest opportunities. Globalization and the development of the network society and the information society have radically changed mobilization techniques. New information and communication technologies have altered the ways in which activists communicate and mobilize. Is typical grassroots mobilization changing as a result of the use of these new communication technologies? How are social actors mobilizing for change in a repressive political system and who is being addressed in a situation of non-governance or misgovernance? How does the spread of innovative ideas and practices, which is playing a central role in the shift of scale, ${ }^{95}$ influence the mobilization techniques employed by activists? At a general level, supply, demand and mobilization are supposedly shaped by the supranational and national context. At a certain level, the mobilizing context is further coloured by characteristics of contestation, most notably the specific issue concerned. Little is known about

92 Duyvendak \& Hurenkamp, Kiezen voor de Kudde. Lichte gemeenschappen en de nieuwe meerderheid; Melucci, Challenging Codes; V. Taylor, 'Mobilizing for change in a social movement society', pp. 219-230.

93 Q. Wiktorowitz, 'Introduction: Islamic activism and social movement theory', in Q. Wiktorowicz (ed.), Islamic Activism: A social movement approach (Indiana University Press, Bloomington, IN, 2004).

94 See van Kessel's chapter in this volume.

95 Tarrow \& McAdam, 'Scale shift in transnational contention'. 
the way mobilizing contexts vary, how such variation is determined or how it impacts on the characteristics of contestation.

In short, we could ask a series of questions concerning contestation with regard to Africa: Who participates in protest? What are their socio-demographic characteristics? Are they the elite or ordinary people? Why are they protesting (i.e. on which issues)? What forms of protest are being employed (i.e. demonstrations, sit-ins, lobbying, riots)? How are they being mobilized?

First, let us look at who the participants are. Some scholars argue that new information and communication technologies are helping to fabricate new connections among people from diverse backgrounds, resulting in mobilizing structures that might be more diverse and inclusive on gender, race and ethnicity, and nationality. ${ }^{96}$ Indeed, protest participation has gradually normalized and all sorts of people are resorting to protest to demand change. ${ }^{97}$ But it is not clear whether this is the case in Africa too. Are the most deprived people taking to the streets or is it only the elite? Moreover, the question remains as to whether new information and communication technologies are as influential in Africa as they appear to be in the Western world.

The question of what people are protesting for focuses on issues and motivation. Issues may have different origins, in the form of conflicting principles or conflicting material interests. For extremely deprived people, the struggle to survive takes up all their time and energy. Does this imply that mainstream African protest has its origin in material interests and that instrumental motivations push people on to the streets?

Concerning forms of protest, the action repertoire is influenced by the (supra)national and mobilizing context. This may have an effect on whether activists organize large mass-based organizations, whether they lobby and organize petitions, or whether discontent turns into bread riots. Obviously, all these forms of contestation have their own motivational dynamics and appeal to different people.

\section{Conclusion}

This chapter has discussed how developments in the real world have influenced the study of contention. It started with classical approaches, such as mass society and collective behaviour theories, that tried to explain large movements before the Second World War like Nazism and Communism. The growth of social movement activity with a goal-oriented and rational focus in the 1960s

called for more structural and rational approaches such as the political process

96 Taylor, 'Mobilizing for change in a social movement society'.

97 Meyer \& Tarrow, Towards a Movement Society?; see also Norris et al., 'Who demonstrates?' 
and resource-mobilization approach and for more social constructivistic approaches derived from cultural sociology and social psychology. Since the 1990s, activists mobilizing for social change have been operating in a dramatically changing social-political context. Social movement scholars have reacted with arguments about synergy, making the case for synergizing structural and social constructivistic approaches. The final sections therefore presented an explanatory framework for contextualized contentious politics in which we can integrate influences from supra(national) and mobilizing contexts within a particular country. Obviously, a comprehensive master framework that brings these elements together is still to be built. The most important challenge is probably the integration of the concepts proposed. In this regard, moving from static to more dynamic explanations of contentious politics is important. The recent conceptual shift, proposed by McAdam, Tarrow and Tilly, ${ }^{98}$ to look for mechanisms and processes that occur in many different kinds of movements and that lead to different outcomes depending on the specific contexts within which they occur may be a useful direction. Indeed, studying contentious politics in a more dynamic way would do justice to the theoretical and empirical richness of the concepts and could be crucial for gaining better insight into the processes at hand. The study of contentious politics is now much richer, more sophisticated and more synergized than it was sixty years ago. The 'war on paradigms" ${ }^{99}$ of the 1980s and 1990s seems to have been replaced by a new decade of 'synergy'.

The 'roadmap' presented here has tried to exemplify the approaches used in the study of social movements over the last sixty years and it is hoped that the explanatory framework will be useful to social movement scholars all over the globe, but especially in Africa. Social movements have been well studied in the European and Latin American contexts but only sporadically in Africa, and then mainly in South Africa. Current developments across African societies might invite social movement scholars to try and explain these dynamics of contention by applying insights from the social movement literature as developed in nonAfrican contexts.

98 D. McAdam, S. Tarrow \& C. Tilly, Dynamics of Contention (Cambridge University Press, New York, 2001); McAdam et al., 'Comparative perspectives on contentious politics'.

99 S. Tarrow, 'Bridging the quantitative-qualitative divide', in: H.E. Brady \& D. Collier (eds), Rethinking Social Inquiry: Diverse tools, shared standards (Rowman and Littlefield, Lanham, MD, 2004). 


\title{
Speaking to global debates through a national and continental lens: South African and African social movements in comparative perspective
}

\author{
Adam Habib \& Paul Opoku-Mensah
}

This chapter reflects on the empirical cases of contemporary social movements in South Africa and Africa in relation to the debates that have emerged in the global academy. In particular it responds to two assertions that have become common in this debate; first, that the fulcrum of social struggles for a human development agenda has shifted from the arena of production to consumption, and second, that identity movements and struggles are replacing the overtly material ones, especially in postindustrial societies. Studies of social movements in South Africa and Africa, however, suggest that both these assertions are too simplistic, and that in reality a more nuanced interpretation is required. While the scale of social struggles has expanded in the arena of consumption, the South African and African case studies suggest that movements in the arena of production not only continue to retain vibrancy, but also are crucial to the sustainability of struggles of consumption. Moreover these same case studies suggest that while identity movements and struggles are indeed on the increase, material issues are as relevant to these struggles as they have been to the earlier social movements. Finally the chapter concludes with the argument that these movements are crucial in many of the democratizing societies for creating the substantive uncertainty that is necessary for facilitating the accountability of political elites to their mar-

1 This chapter is in part based on the concluding chapter of R. Ballard, A. Habib \& I. Valodia (eds), Voices of Protest: Social Movements in Post-Apartheid South Africa (University of KwaZulu-Natal Press, Pietermaritzburg, 2006). 
ginalized citizens so that a more sustainable human-oriented development agenda is realized.

\section{Introduction}

The study of social movements has undergone something of a revival in recent years, partly due to the resumption of social struggles on the international plane. The most prominent is of course the anti-globalization movement that first made its public presence felt on the streets of Seattle but has since mobilized in almost every city where any of the international financial agencies have held their meetings. Indeed, this explosion of global struggle has spawned an unprecedented number of transnational organizations, the vast majority of which are directed at reforming some element of the global order. ${ }^{2}$

Social struggles have not only increased on the international plane or in OECD countries but have also become a prominent feature of the political scene in many of the countries of the South. This is especially so in the Third Wave of democracies where a decade or two of market-oriented economic reforms have eroded the popular support and legitimacy of newly established democratic regimes. ${ }^{3}$ One of the most prominent cases of national struggle is the Chiapas rebellion in Mexico but similar popular revolts have manifested themselves in many parts of the developing world and have even toppled governments.

Where social struggles emerge, academics and scholars often follow. The explosion of global and national struggles has provoked a plethora of studies on global and national social movements ${ }^{4}$ but there was also an independent impetus for these social movement studies. An earlier generation of studies polarized into three distinct blocs inspired by resource mobilization, political opportunity and identity-oriented theories. In recent years however, there have been a number of initiatives to bridge the divides and develop a comprehensive explanation of the rise, operations and decline of social movements. ${ }^{5}$

2 H. Anheier, M. Glasius \& M. Kaldor, 'Introducing global civil society', in H. Anheier, M. Glasius \& M. Kaldor (eds), Global Civil Society (Oxford University Press, Oxford, 2001).

3 A. Przeworski, Sustainable Democracy (Cambridge University Press, Cambridge, 1997).

4 J. Clark, Global Civic Engagement (Earthscan, London, 2003); J. Keane, Global Civil Society? (Cambridge University Press, Cambridge, 2003); R. Taylor, Creating a Better World: Interpreting global civil society (Kumarian Press, Bloomfield, 2005).

5 D. della Porta \& M. Diana, Social Movements: An introduction (Blackwell Publishers, MA, 1999); D. McAdam, S. Tarrow \& C. Tilly, Dynamics of Contention (Cambridge University Press, New York, 2001). 
Contemporary social movement theories are not only distinguished by the way they resort to a multiplicity of explanatory variables but also to the rise of new popular orthodoxies. Two of the most prominent of these are that identity movements and struggles are replacing the previously overtly material ones, and that the fulcrum of social struggles for a human-development agenda has shifted from the arena of production to consumption, both of which are seen to expressly manifest themselves in post-industrial societies. This chapter speaks to these two assertions in the global academy but from the perspective of the African experience.

The empirical foundation of the analysis is the first comprehensive national study of contemporary social movements in South Africa, which was convened by the Centre for Civil Society and the School of Development Studies at the University of KwaZulu-Natal, and was funded by Atlantic Philanthropies and the Ford Foundation. It represented the collaborative engagement of over twenty academics and researchers and studies of seventeen social movements, struggles or organizations were undertaken over a two-year period. Similar research questions on the character, leadership, operations and significance of the movements were addressed in each of the studies and resulted in a level of generalization about South African social movements. ${ }^{6}$ The case studies are supplemented by an ever-growing body of empirical analyses of contemporary social movements across Africa, a collection that constitutes a unique conceptual lens through which the assumptions of and the debates in the global academy can be tested and reflected upon respectively.

Is the African experience an appropriate reference point for engaging the debates in the global academy? African societies are, of course, not post-industrial societies and so it may seem unfair to respond to the theoretical assertions on social movements from a context that is so socio-economically different. But is it intellectually sustainable for the global academy to develop a theory of social movements - with universal ambitions - on the narrow experiences of postindustrial societies? Even if it were, one African experience - the South African one - would still be relevant as the country represents an interesting hybrid, reflecting the post-industrial and developing worlds. And it is also a transitional society in constant evolution and a state of flux, with elements of both the past and the present. This makes it a useful social laboratory within which social scientists can investigate collective expressions of protest, state response and societal evolution.

This chapter thus addresses the debates on social movements in the global academy from the perspective of the African continent's, and in particular South Africa's, contemporary social struggles. It begins by summarizing the

6 Ballard, Habib \& Valodia (eds), Voices of Protest. 
debates in the social movement literature on the relevance of identity and material struggles, and the arenas in which they can be mobilized. This is followed by an analysis of the South African and African case studies and how they speak to the global debates. The chapter then considers the relevance of these movements for democracy and a human-oriented development trajectory, with the conclusion drawing together the major threads of the analysis.

\section{New-found dogmas in contemporary social movement theory}

Current explanations of social movements are built on three foundational elements: the political structure that defines opportunities and constraints, ${ }^{7}$ the human and financial resources that enable a movement's mobilization and operations, ${ }^{8}$ and the identities that provide the impetus for actors to become involved and provide legitimacy for the movement. Of course these three distinct elements were, as indicated earlier, the explanatory variables that were advanced by three distinct schools in social movement theory. Yet it is the third, which focuses on the central role of identity, that has been particularly influential in contemporary explanations of social movements. This identity-oriented paradigm insists that the identity, status and the values of actors are what make the ultimate difference in the mobilization of collectives. ${ }^{9}$ These subjective elements, they argue, create what Melucci ${ }^{10}$ terms systems of reference that enable the shared feelings of grievance or outrage that prompt people to form collectives and actively enter the political arena.

It is important to remember the context in which this theory originated. Largely developed to explain the rise and influence of so-called 'identity-based' movements - racial or religiously constructed, women's, gay rights and even environmental collectives - in economically developed western democracies, it challenged Marxist interpretations that placed distributional issues at the centre of explanations of social movements. Yet this paradigm, while initially popular within the academy, nevertheless lost its shine as it was subjected to a barrage of criticism in the 1990s. However the explanations once again came into vogue

7 S. Tarrow, Power in Movement: Social movements, collective action and politics (Cambridge University Press, New York, 1994).

8 J. McCarthy \& M.N. Zald, The Trend of Social Movements in America: Professionalization and resource mobilization (General Learning Corporation, Morristown, NJ, 1973); C. Tilly, From Mobilisation to Revolution (Addison-Wesley, Reading, MA, 1978).

9 A. Touraine, The Voice and the Eye: An analysis of social movements (Cambridge University Press, Cambridge, 1981); A. Melucci, Nomads of the Present: Social movement and identity needs in contemporary society (Temple University Press, Philadelphia, PA, 1989).

10 Melucci, Nomads of the Present. 
with the explosion of transnational organizations and mobilizational collectives, many of which questioned and challenged the neoliberal tenets of official globalization initiatives.

The point to note is that this explanatory paradigm's popularity returned among not only its earlier advocates but also among many of its earlier critics within the academy and the movements themselves. The well-known sociologist Michael Buroway ${ }^{11}$ makes the case for why an identity-based explanatory paradigm is more useful for understanding the myriad of social struggles against the various elements of official globalization. In his view, globalization as it is defined and advanced by its political, policy, and corporate architects has enabled the expansion of the market in hitherto uncharted territory. The net effect is that its consequences have begun to impact on a far wider set of stakeholders than in earlier epochs. He thus concludes that in this 'post communist era progressive struggles have moved away from distributional politics to focus on identity politics or what Nancy Fraser calls a politics of recognition'. ${ }^{12}$

A related but distinct assertion in the contemporary explanation of social movements and struggles is the increasingly widely held belief among both scholars and activists that the fulcrum of mobilization and anti-hegemonic political activity is shifting from the realm of production to that of consumption. Again, Buroway's article makes this assertion explicit. Drawing on Polanyi ${ }^{13}$ he suggests that counter-hegemonic potential lies not only in the realm of production, as classically understood, but also in the domain of consumption and the market:

Everyone suffers from the market in as much as unrestrained it leads to the destruction of the environment, global warming, toxic wastes, the colonization of free time, and so forth. ... Whereas alienated and degraded labour may excite a limited alternative, it does not have the universalism of the market that touches everyone in multiple ways. It is the market, therefore, that offers possible grounds for counter hegemony. We see this everywhere but especially in the amalgam of movements against the many guises of globalization. ${ }^{14}$

And he is not the only one with this view in the academy. David Harvey ${ }^{15}$ in The New Imperialism arrives at a similar conclusion on the basis of his analysis of neo-liberalism, which he argues is Capital's response to the problems of over-accumulation that emerged in the last three decades of the twentieth century. His analysis holds that the dominant logic of capital accumulation in the

11 See M. Burawoy, 'For a sociological Marxism: the complementary convergence of Antonio Gramsci and Karl Polanyi’, in Politics and Society, 31, 2 (2003).

12 Burawoy, 'For a sociological Marxism', p. 242.

13 K. Polanyi, The Great Transformation (Beacon Press, Boston, 1957).

14 Burawoy, 'For a sociological Marxism', p. 231.

15 D. Harvey, The New Imperialism (Oxford University Press, Oxford, 2003). 
contemporary period is what he calls, following Rosa Luxemburg, 'accumulation by dispossession' which forces 'the costs of devaluations of surplus capitals upon the weakest and most vulnerable territories and populations'. ${ }^{16}$ The result is an explosion of struggles outside the arena of production around the privatization of basic services and the displacement of the poor and marginalized. Harvey concludes that greater attention needs to be paid to the struggles occasioned by accumulation through dispossession and that links need to be forged between these and proletarian struggles at the point of production.

While there is not much that can be disputed in Harvey's carefully constructed and nuanced conclusion, the more extreme readings of these processes both within the academy and among social-movement activists must be questioned. In the case of the latter, a growing perception has been that unions have lost their potential to serve as institutional agents for counter-hegemonic struggle, and the only hope now remains in a range of radical social movements located in the arena of reproduction. Ashwin Desai has explicitly expressed this view, as has Richard Pithouse who asserts that:

... the idea of the multitude has freed many from both the fetish of the proletariat as the only viable agent of challenge to capital and the fetish of the nation as defender against capital. Given the reality that most resistances in contemporary South Africa are at the point of consumption (basic services, housing, health care, education etc) rather than production, and are largely community rather than union driven, as well as the complete immersion of the South African elite into the trans-national elite, these are very welcome releases. ${ }^{17}$

How then do these two assertions, which have effectively become the dominant orthodoxies not only within the social-movement literature but also among progressive social-movement activists themselves, stand up to the South African and wider continental case studies? It is this question that the next section considers.

\section{Reflections on the South African and continental case studies}

It may be useful to begin this reflection on social movements in contemporary Africa by focusing on South Africa and with the obvious and perhaps banal remark that these institutions are essentially the products of the post-apartheid moment. However this is not to suggest that they are emerging from a vacuum.

16 Harvey, The New Imperialism, p. 184-185.

17 Richard Pithouse, 'Solidarity, co-option and assimilation: The necessity, promises and pitfalls of global linkages for South African movements', in Development Update, 5, 2 (2004), p. 182; see also M. Hardt \& A. Negri, Empire (Harvard University Press, Cambridge, MA, 2000). 
Clearly their strategies, activities and orientations draw on the experiences, repertoires and other rich heritage of struggle in South Africa. Nevertheless, the post-apartheid moment has imparted a particular character to them. Whether it is the economic crisis of the post-apartheid South Africa as is manifested in its unemployment and poverty rates, the cost recovery initiatives of the local state, made mandatory by the policy choices of post-1994 state elites or the democratic and essentially liberalized political environment of this period, all crucially influenced the genesis of these movements, their evolution and their strategies and tactics. But this is where their similarity ends.

This is important to note because in the emotive atmosphere within which political debate occurs these movements are often implicitly projected by both state elites and public officials, and social-movement activists themselves as a coherent homogenous entity. Some political leaders and public officials have intimated that these movements undermine democracy because of their engagement in extra-institutional action. And some social-movement activists and intellectuals, on the other hand, portray the movements in romanticized terms, describing them as arenas of free democratic debate and participation epitomized in a "principled internationalism, a socialist vision, and an independent mass-based mobilisation and struggle as an ideological and organisational alternative to the capitalist ANC'. ${ }^{18}$

The South African and continental case studies of social movements both challenge the assumption of homogeneity underlying these views, for not only do they speak to a somewhat hypothetical ideal rather than to the current reality of social movements but they also generalize the respective ideal as characteristic of all within the social-movement universe. As a way of reminding ourselves of the heterogeneity of grassroots activism, it is useful to undertake a typology of what it is that social movements in South Africa and the wider continent oppose.

First, a large swathe of activism in South Africa is directed against government policy on distributional issues, particularly with regard to the inability of many poor South Africans to access basic services. Privatization and cost recovery are perceived as the key elements debilitating delivery. Movements that reflect such campaigns include, among others, the Soweto Electricity Crisis

18 D. McKinley, 'The rise of social movements in South Africa', in Debate: Voices from the South African left, May 2004, p. 17-21. See also P. Bond, 'Strategies for social justice movements from Southern Africa to the United States', Foreign Policy in Focus (FPIF), January 2005; Gudrun Lachenmann, 'Civil society and social movements in Africa: The case of the peasant movement in Senegal', The European Journal of Development Research, 5, 2 (1993), pp. 68-100. 
Committee, ${ }^{19}$ the Anti-Privatisation Forum, ${ }^{20}$ the former Concerned Citizens Forum, ${ }^{21}$ the now-divided Western Cape Anti-Eviction Campaign, ${ }^{22}$ and the Treatment Action Campaign. ${ }^{23}$

Similarly, the emergence of social movements on the African continent has taken place within the context of deprivation, rights denial and injustice. This context is characterized by a lack of access to basic services like water, medicine, housing and electricity. It is the various claims to and demands on governments for these rights that have shaped the logic and coherence of the various movements that have emerged on the continent. These include but are not limited to the Ghanaian, Zambian and Zimbabwean Anti-Privatisation Forums that are similar to the one operating in South Africa. ${ }^{24}$

Second, some movements oppose the state, banks and private landlords through opposition to eviction and attempts to secure land tenure. Movements in South Africa that have taken up these struggles are the Landless People's Movement, ${ }^{25}$ the Concerned Citizens Group ${ }^{26}$ and the Western Cape AntiEviction Campaign. ${ }^{27}$ Social movements in other parts of Africa have mobilized in response to similar issues, including the land question. This includes, for instance, the San people in Botswana who achieved global visibility in December 2006 following a court decision that affirmed their right to their ancestral lands in the Kalahari Desert, a right that had been usurped by the Botswana government. ${ }^{28}$ In Kenya too there is an emerging land movement that is often

19 A. Egan \& A. Wafer, 'Dynamics of a 'mini mass movement': Origins, identity and ideological pluralism in the Soweto electricity crisis committee', in Ballard, Habib \& Valodia (eds), Voices of Protest.

20 S. Buhlungu, 'Upstarts or bearers of tradition? The anti-privatisation forum of Gauteng', in Ballard, Habib \& Valodia (eds), Voices of Protest.

21 P. Dwyer, 'The concerned citizens forum: A fight within a fight', in Ballard, Habib \& Valodia (eds), Voices of Protest.

22 S. Oldfield \& K. Stokke, 'Building unity in diversity: Social movement activism in the Western Cape anti-eviction campaign', in Ballard, Habib \& Valodia (eds), Voices of Protest.

23 S. Friedman \& S. Mottiar, 'Seeking the high ground: The treatment action campaign and the politics of morality', in Ballard, Habib \& Valodia (eds), Voices of Protest.

24 M.C. Brill, 'Exploring the emerging social movements in Africa at the third African social forum', Africa Action, January, 2005; Bond, 'Strategies for social justice movements'; P. Bond, Fanon's Warning: A civil society reader on the new partnership for Africa's development (Africa World Press, Trenton, NJ, 2005).

25 S. Greenberg, 'The landless people's movement and the failure of post-apartheid land reform', in Ballard, Habib \& Valodia (eds), Voices of Protest.

26 Dwyer, 'The concerned citizens forum'.

27 Oldfield \& Stokke, 'Building unity in diversity'.

28 Brill, 'Exploring the emerging social movements in Africa'. 
associated with the organization commonly known as the Kenyan Land Alliance. $^{29}$

Third, there is a base of familiar unions in post-apartheid South Africa that are targeting government policy on employment conditions as well as labour practices in the private sector. Most of these unions are housed within COSATU which, although in alliance with the current government, has nevertheless continued to engage in adversarial mass action. ${ }^{30}$ The limitation of these formalsector unions has, however, been their inability to deal with the changing nature of work and the growing layers of informal workers. This challenge has been taken up by nascent campaigns like the Self-Employed Women's Union (SEWU) that target the local state on accommodating workers and traders rather than challenging their bosses about conditions of service. Notwithstanding the SEWU's demise in 2004, its agenda is continuing to impact on mainstream unions. $^{31}$

Although African trade unions have lost their traditional dominance as they now have to share their political space with other actors, they still remain central to employment issues. Across the continent, they have been at the forefront of mass demonstrations to change standards of employment ${ }^{32}$ and in fact remain one of the few organizations that have continuously had continental reach through the Organization of African Trade Union Unity (OATUU). Other organizations, like the Kenya Human Rights Commission (KHRC), have also worked in this area to highlight the plight of workers in export-processing zones (EPZ) and those working on flower farms. ${ }^{33}$ Moreover, oil workers on several of the delta platforms have similarly pressed vigorously not only for higher wages but also for broader community demands through their movements in Nigeria's delta region. ${ }^{34}$ This 'social movement unionism' ${ }^{35}$ is typical of tradeunion activity across the continent, including South Africa, and has most

29 Onyango Oloo, 'Social movements set to assert their presence at WSF Nairobi 2007', Pambazuka News (http://pambazuka.org/en/category/comment/38952, December 21, 2006).

30 A. Habib \& I. Valodia, 'Reconstructing a social movement in an era of globalisation: A case study of the Congress of South African Trade Unions (COSATU)', in Ballard, Habib \& Valodia (eds), Voices of Protest.

31 A. Devenish \& C. Skinner, 'Collective action in the informal economy: The case of the self employed women's union, 1994-2004', in Ballard, Habib \& Valodia (eds), Voices of Protest.

32 Oloo, 'Social movements set to assert their presence at WSF Nairobi 2007'.

33 Ibid.

34 Bond, 'Strategies for social justice movements'.

35 E. Webster \& K. Von Holdt, 'Towards a socialist theory of radical reform: From resistance to reconstruction in the labour movement', paper delivered to the Ruth First Memorial Symposium (University of the Western Cape, 1992). 
recently been demonstrated in the Zimbabwean Congress of Trade Union's (ZCTU) participation in the democratic struggle in Zimbabwe.

Fourth, significant activism is being directed against corporations and the government on issues of pollution and the environment. One such action in South Africa that has been sustained over a long period of time is community action in South Durban. In addition, the Environmental Justice Networking Forum represents a group of organizations that have been instrumental in shifting popular environmental consciousness from green conservation issues to brown issues that emphasize social justice. ${ }^{36}$ The environment also provides a target for social-movement mobilization in the rest of Africa. Two of the more visible movements at the forefront of such mobilization include Kenya's Green Belt movement founded by the 2004 Nobel Peace Prize winner Wangari Maatha $^{37}$ and the environmental movements in the Niger Delta whose strategies have included sit-ins at the local offices of multinational companies and, increasingly, more radical and violent actions involving the kidnapping of foreign workers. ${ }^{38}$

Fifth, some organizations in South Africa have sought to counter social prejudice against refuges, ${ }^{39}$ sexual minorities ${ }^{40}$ and women, ${ }^{41}$ especially through reforms of government policy infrastructure. The HIV/AIDS crisis provides a natural target for social-movement mobilization against the policy and servicedelivery infrastructure in Africa. While it is a stand-alone movement in some regions, in others it is part of the economic justice movement and/or the women's movement. ${ }^{42}$ The core of the movement is predominantly women, although its leadership tends to be primarily male. It is fighting against the

36 J. Cock, 'Connecting the red, brown and green: The environmental justice movement in South Africa', in Ballard, Habib \& Valodia (eds), Voices of Protest.

37 C. Obi, 'Environmental movements in sub-Saharan Africa: A political ecology of power and conflict, civil society and social movements. United Nations Research Institute for Social Development. Programme Paper 15, January 2005; M. Salih, Environmental Politics and Liberation in Contemporary Africa (Kluwer Academic Publishers, London, 1999).

38 Obi, 'Environmental movements in sub-Saharan Africa'; Bond, 'Strategies for social justice movements'.

39 B. Amisi \& R. Ballard, 'In the absence of citizenship: Congolese refugee struggle and organisation in South Africa', in Ballard, Habib \& Valodia (eds), Voices of Protest.

40 T. Dirsuweit, 'The problem of identities: The lesbian, gay, bisexual, transgender and intersex social movement in South Africa', in Ballard, Habib \& Valodia (eds), Voices of Protest.

41 S. Hassim, 'The challenges of inclusion and transformation: The women's movement in democratic South Africa', in Ballard, Habib \& Valodia (eds), Voices of Protest.

42 Brill, 'Exploring the Emerging Social Movements in Africa'. 
prejudice and stigma associated with HIV/AIDS as well as for permanent treatment for HIV/AIDS patients. It thus involves diverse actors ranging from healthcare and/or home-based care providers, people living with HIV/AIDS, educators, professionals, the gay, lesbian and bisexual communities, trade unions and some faith-based communities. Examples include the Pan African Treatment Access Movement (PATAM); Gays and Lesbians of Zimbabwe (GALZ); Zimbabwean Activists on HIV/AIDS (ZAHA) and the Kenyan Network of Women with AIDS/HIV (KENWA). These movements all frame the HIV/AIDS challenge within the context of human rights and economic justice, with the objective of achieving universal, accessible and comprehensive treatment and care for all those living with HIV/AIDS. For instance KENWA, with its more than 3000 members, has focused its mobilization on issues of human rights (especially women's rights), treatment access, stigma, reproductive rights and access to credit, insurance and mortgages. ${ }^{43}$

Finally, movements in Africa that oppose multilateral organizations and transnational corporations (TNC's) because of their links with broader global movements like the Jubilee campaigns. ${ }^{44}$ The most notable of these is Jubilee South Africa, which opposes multilateral organizations and foreign corporations in relation to debts that cannot be paid or in terms of claiming compensation from businesses that operated in South Africa during apartheid. ${ }^{45}$ It has also lobbied the current South African government to take a stronger social-justice approach, particularly regarding reparations for victims identified through the Truth and Reconciliation Commission. Other African examples include the Third World Network (TWN), the Zimbabwe Coalition on Debt and Development (ZIMCODD), the Uganda Debt Network, the Third World Forum, the West African Social Forum, the Forum of African Alternatives and the Senegalbased Environment and Development Action-Third World (ENDA). ${ }^{46}$ In ad-

43 Ibid.

44 Bond, 'Strategies for Social Justice Movements'; Alingué, Madeleine Andebeng L., 'African Transatlantic Resistance and Movements', in Atilio Boron \& A. Gladys Lechini (eds), Politics and Social Movements in an Hegemonic World: Lessons from Africa, Asia and Latin America (Consejo Latinoamericano de Ciencias Sociales (CLACSO), Buenos Aires, 2005), pp. 245-258; Joan Baxter, "Another Africa is possible': Social movements organize to challenge dominant economic policies', From Africa Recovery, 16, 1 (April 2002).

45 C. Rustomjee, 'From economic debt to moral debt: The campaigns of jubilee South Africa', in Ballard, Habib \& Valodia (eds), Voices of Protest.

46 Ebrima Sall, 'Social movements in the renegotiation of the bases for citizenship in West Africa', Current Sociology, 52, 4 (2004), pp. 595-614 (http://csi.sagepub. com/cgi/content/abstract/52/4/595); Bond, 'Strategies for social justice movements'; Brill, 'Exploring the emerging social movements in Africa'; Kehinde Olayode, 'Prodemocracy movements, democratisation and conflicts in Africa: Nigeria, 1990- 
dition to working primarily on debt cancellation, trade and foreign aid, the Jubilee Campaigns and debt and development groups like AFRODAD are also engaged in the interconnected issues of access to services. Trade unions, other forms of organized labour, political parties and think tanks - many of them anticapitalist in orientation - also engage with this movement at varying levels. ${ }^{47}$

In summary, social movement mobilization in Africa and South Africa is a product of, and responds to, a concrete context of deprivation, rights denial and injustice. The continent's social-movement landscape is incredibly heterogeneous but for analytical purposes it is possible to categorize African movements as follows: Anti-Corporate Globalization/Economic Justice; Democracy and Transparency; Environmental; HIV/AIDS; and Women and Youth. ${ }^{48}$

This heterogeneity is exhibited not simply in terms of activities or issues. Increasingly, it is being reflected in the strategies adopted by social movements in Africa too. Even movements that operate under the rubric of anti-globalization adopt different strategies against multilateral organizations like the IMF, the World Bank, the World Trade Organization (WTO) and governmental bodies like the African Union. While some movements are willing to collaborate with these institutions, others are adopting a more confrontational approach. The willingness to collaborate and engage seems to vary by region, with movements in Southern Africa, particularly in South Africa, preferring nonengagement. West Africans, by contrast, appear to have the largest number of organizations willing to engage with the African Union and the international financial institutions. Overall, a radicalization and militarization of Africa's social movements would seem to be under way, with the use of violence by the movements in the Niger Delta providing the best example of this phenomenon. ${ }^{49}$

This typology of social movements and the thematic concerns they are mobilizing around suggest that distributional issues are still central in Africa. Indeed, a good proportion of the movements in categories one, two, three and six, have emerged as a response to the economic crisis and its manifestations,

1999', African Journal of International Affairs, 10, 1-2 (2007), pp. 127-146; Baxter, 'Another Africa is possible'.

47 Brill, 'Exploring the emerging social movements in Africa'.

48 Sall, 'Social Movements in the renegotiation of the bases for citizenship'; Bond, 'Strategies for social justice movements'; Brill, 'Exploring the emerging social movements in Africa'; Olayode, 'Pro-democracy movements, democratisation and conflicts in Africa'.

49 Brill, 'Exploring the emerging social movements in Africa'; Bond, 'Strategies for social justice movements', and Patrick Bond, Fanon's Warning: A civil society reader on the new partnership for Africa's development (Africa World Press, Trenton, NJ, 2005). 
and were deliberately founded to effect a redistribution of scarce resources in favour of marginalized communities. It is only categories four and five, those addressing environmental concerns and prejudices directed against specific communities respectively, that are not overtly organized to speak directly to distributional deficits.

Even in these explicitly identity-based movements however, distributional issues colour their politics. The case studies in South Africa of the gay, ${ }^{50}$ environmental, ${ }^{51}$ women's ${ }^{52}$ and refugee ${ }^{53}$ movements show that even while identity is an important driver within these movements, distributional questions have by no means been marginalized. In fact, these case studies demonstrate that a huge contestation exists within these movements around distributional issues. As Dirsuweit ${ }^{54}$ points out, the gay movement is divided over the questions of distribution that are raised by the poverty of a significant proportion of its members. The same is true of the environmental movement, which is increasingly being forced to take on 'brown' rather than 'green' issues, thus addressing the socio-economic concerns of marginalized communities and highlighting the principle of environmental justice. ${ }^{55}$ Similarly a study of two prominent environmental movements in Sub-Saharan Africa, the Movement for the Survival of Ogoni People of Nigeria's Niger Delta and the Green Belt Movement of Kenya, demonstrates that they operate within a transformative logic in which struggles for power over environmental resources connect with broader popular social struggles for empowerment and democracy. Many environmental conflicts in Africa are driven by a challenge to dominant power relations that continue to benefit the 'few' and threaten the survival of the majority. ${ }^{56}$

These case studies suggest that identity-based social movements in Africa, typical of those in the developing world, are being driven by an intricate mix of identity and distributional pressures. And there is no reason to assume that this is a peculiarly African phenomenon. Indeed, Teresa Dirsuweit ${ }^{57}$ suggests that a similar mix of pressures defines movements in the industrialized world too.

Dirsuweit, 'The problem of identities'.

1 Cock, 'Connecting the red, brown and green'.

52 Hassim, 'The challenges of inclusion and transformation'.

53 Amisi \& Ballard, 'In the absence of citizenship".

54 Dirsuweit, 'The problem of identities'.

55 Cock, 'Connecting the red, brown and green'.

56 Obi, 'Environmental movements in sub-Saharan Africa'. See also Salih, Environmental Politics and Liberation in Contemporary Africa.

57 Reflecting on the writings of I.M. Young, Justice and the Politics of Difference (Princeton University Press, Princeton, 1990) and Inclusion and Democracy (Oxford University Press, Oxford, 2000); and N. Fraser, Justice Interruptus: Critical Reflections on the 'postsocialist' condition (Routledge, New York, 1997). 
After all, there is growing evidence that inequalities and poverty are increasing in industrialized countries. This, together with the fact that a large part of the world where social movements are active are developing contexts, suggests that distributional issues need to be an explicit component of the theory-building agenda of social-movement scholars.

What of the second assertion that the arena of production is no longer as relevant for organizing counter-hegemonic struggles? Implicit in this view is the suggestion of union impotence in the face of a resurgent community activism to represent the interests of marginalized communities. But the South African case studies suggest that this is too easy a read of contemporary developments. After all, even in the pre-1994 era, community struggles accounted for a significant number, if not the majority, of the struggles against the apartheid state from as far back as the 1950s. ${ }^{58}$ Even more important is the fact that the union movement today is a vibrant component of the social-movement universe, notwithstanding its alliance with the ruling party. COSATU may not phrase its agenda and activities in counter-hegemonic terms but this has not completely disarmed the federation.

This is the central message of Habib and Valodia's ${ }^{59}$ analysis of COSATU's evolution, operations and politics in the contemporary era. They argue that a political disjuncture with the dominant element in the ANC leadership has emerged following the government's adoption of the Growth, Employment and Redistribution (GEAR) Strategy in 1996. Indeed they maintain that this has translated into a progressively more adversarial stance on the part of COSATU vis-à-vis the government and the ANC leadership.

This has manifested itself in general strikes and struggles against GEAR, AIDS and Zimbabwe in recent times. Some social movements, like TAC, have of course recognized this and explicitly entered into an alliance with this social movement in the realm of production. It needs to be noted that in pure membership terms, COSATU, which had a registered membership of 1.8 million in 2003, dwarfs almost all the other social movements combined. ${ }^{60}$

The problem of course is the impression created by the union federation's alliance with the ANC, an alliance that has at times placed the federation on the defensive, forcing it to conduct some struggles within the institutional parameters of the Tripartite Alliance. But the movement's combativeness resurfaces from time to time. The most recent examples are COSATU's vociferous attacks on Mbeki's leadership and his presidency: he was accused of sliding the country

58 M. Mamdani, Citizen and Subject: Contemporary Africa and the legacy of late colonialism (Princeton University Press, Princeton, NJ, 1996).

59 Habib \& Valodia, 'Reconstructing a social movement in an era of globalisation'.

60 Ibid. 
towards a dictatorship ${ }^{61}$ and supporting Jacob Zuma's bid for the leadership of the party and the country. These developments, together with COSATU's social-movement orientation, suggest that the unions are still alive and very relevant to the struggle to represent marginalized communities. Again this suggests, if only because South Africa's socio-economic context is so similar to those in the rest of the developing world, that the realm of production cannot be ignored as an arena of mobilization and organization of counter-hegemonic struggle and that, as a result, unions must be retained as one of the institutional agencies as they are capable of conducting and leading such struggles. The South African case studies imply that the arena of production is as relevant as that of consumption in hosting organizations for the counter-hegemonic struggle prompted by the multiple manifestations of globalization.

This is also true for other parts of Africa, both at the national and continental levels. In the latter arena, OATUU still remains a visible player in institutional politics ${ }^{62}$ but perhaps the role of the trade unions is most visible in the democratic movements that have challenged and overthrown dictatorships in a number of African countries. In Zambia, for instance, the Chiluba-led opposition that challenged and eventually defeated the entrenched rule of Kaunda's United Independence Party was the product of the Congress of Trades Unions. Similarly, opposition in Zimbabwe to Mugabe's dictatorial regime has been facilitated by the National Constitutional Assembly (NCA), a pro-democracy network whose membership comprises the main civil-society organizations in Zimbabwe including the Zimbabwe Council of Churches, the Zimbabwe National Students' Union, and the Zimbabwe Congress of Trade Unions (ZCTU). The main opposition party, the Movement for Democratic Change (MDC), is itself a product of the NCA, having been formed by the Zimbabwe Congress of Trade Unions in $1999 .{ }^{63}$ Across the continent, with weakened opposition parties and legislatures, trade unions still remain the vanguard of the democratic movement.

The African case studies, including the South African one, strongly contest two of the orthodoxies evident in the contemporary global literature on social movements. At best, they recommend a more nuanced reading, one that stresses the relevance of distributional concerns and their ability to mobilize collectives, and the importance of the sphere of production as a site for counter-hegemonic activity. Of course it is recognized that these orthodoxies speak to some aspects of current realities, but only partially. More detailed and extensive descriptions

61 Business Day, 2 June 2006.

62 Brill, 'Exploring the emerging social movements in Africa'.

63 A. Habib \& P. Opoku-Mensah, 'Mobilizing across Africa: Civil society and democratisation', in South African Yearbook of International Affairs 2002/03 (South Africa Institute for International Affairs, 2003). 
of social-movement realities would recognize the equal relevance of identity and distributional concerns, as they would the simultaneous importance for contemporary social movement struggle of the arenas of both production and consumption. This experience is not necessarily peculiar to Africa. In fact given the bifurcated economic realities of contemporary South Africa and the increasing inequalities around the world, these African case studies could speak to the full realities of social-movement activity across the industrialized and developing worlds.

\section{Social movements, development and democracy in (South) Africa}

What is the impact of these movements on the development trajectory and the consolidation of democracy in South Africa and the rest of Africa? As indicated earlier, some have argued that these movements undermine the democratic project by explicitly challenging, through extra-institutional action, legitimate and democratically elected governments. The essential problem with these interpretations is that they conflate and confuse the stated aims of social movements with their immediate systemic effect. Whatever the ultimate distant goals of these movements may be, their impact needs to be assessed in relation to their immediate systemic effects. And the most obvious tangible effect of social movements on the political landscape of this continent is that they represent the interests of the poor and marginalized, and put pressure on governments to pay greater attention to the welfare of these groups. Social movements are thus an avenue for marginalized people and those concerned about their possibility to impact on material distribution and social exclusion and to claim a certain degree of influence and power over the state itself. In contexts where formal political systems have failed to produce significant political parties to directly champion the cause of the poor, social movements contribute to the restoration of plurality in the political system.

This then raises the more significant contribution of contemporary social movements in Africa. The fundamental purpose of a democracy is to make state elites accountable to the citizenry. This is the only way to effect not only public participation but to guarantee a development trajectory in the interests of all the citizenry, including its most marginalized and dispossessed. ${ }^{64}$ Such accountability is founded on the emergence of substantive uncertainty in the political system, and political uncertainty is of course the essence of democracy. It takes one of two distinct forms; institutional or substantive. Institutional uncertainty uncertainty about the rules of the game - implies a vulnerability of the democratic system to anti-democratic forces. Substantive uncertainty - uncertainty

64 A. Habib, 'South Africa: conceptualizing a politics of human-oriented development', Social Dynamics, 34, 1 (2008). 
about the outcome of the game - is about the perceptions of ruling political elites in a democratic system and whether they will be returned to office. ${ }^{65}$ The former - institutional uncertainty - is bad for democracy as it raises the prospect of a return to authoritarianism in the Third Wave of democracies. The latter substantive uncertainty - is good for democracy because it keeps politicians on their toes and makes them responsive to their citizenry.

There has been a great deal of investigation into and reflection on institutional uncertainty ${ }^{66}$ but little work has been done on substantive uncertainty. This should not be surprising given that researchers and activists concerned with democratization have been preoccupied with the business of transcending authoritarian regimes and institutionalizing democratic ones. Nevertheless, the lack of attention to substantive uncertainty has significant political costs and indeed the weakness of many contemporary democracies lies precisely in this arena. Despite the presence of institutional mechanisms to promote substantive uncertainty - legislative elections, the separation of powers, civil liberties, opposition political parties, an independent press - this goal still eludes much of what Huntington ${ }^{67}$ has called the 'Third Wave' of democracies. One reason for this is the shift in power from the legislature to the executive of governments around the globe over the last two decades. Another emanates from the inclination of democratizers and democratization scholars not to rock the boat in societies undergoing democratic transition. Fearful of the very real danger of a reversion to authoritarianism, these actors have focused on procedural aspects of democratization and made significant political and institutional concessions to the state and economic elites of the authoritarian order. Finally, it can be explained by the honeymoon phenomenon during which citizens are reluctant to vote against liberation parties that were responsible for coordinating popular rebellions that brought down authoritarian regimes. ${ }^{68}$

As a result of these developments and peculiar contextual factors, such as the racialized or ethnic character of South Africa's principal opposition parties - the Democratic Alliance (DA), the Inkatha Freedom Party (IFP) and the New

65 A. Schedler, 'Taking uncertainty seriously: the blurred boundaries of democratic transition and consolidation', Democratization, 8, 4 (2001), p. 19.

66 G. O’Donnell \& P. Schmitter, Transitions From Authoritarian Rule: Tentative conclusions about uncertain democracies, 4 (John Hopkins University Press, Baltimore, 1986); G. O' Donnell, 'On the state, democratization and some conceptual problems: A Latin American view with glances at some Post-Communist countries', World Development 21, 8 (1993); S. Huntington, The Third Wave: Democratization in the late twentieth century (University of Oklahoma Press, Oklahoma, 1991).

67 Ibid.

68 F. Fanon, The Wretched of the Earth (Penguin Books, Harmondsworth, 1967), p. 137; Mamdani, Citizen and Subject, p. 21; A. Mbembe, On the Postcolony (University of California Press, Berkeley/LA, 2001), p. 104. 
National Party (NNP) - the ANC has not been seriously threatened at the polls. This lack of substantive uncertainty has eroded the citizenry's leverage vis-à-vis state elites. The ANC, as the dominant party in the liberation movement, came to office with an overwhelming electoral mandate but, despite this, its policy concessions over the last decade have been largely to foreign investors and domestic capital (both black and white) because it was able to take its citizens' votes for granted. Policy concessions in favour of capital are most graphically reflected in the abandonment of the Reconstruction and Development Programme (RDP) and the adoption of GEAR. The net effect has been a transition that has de-racialized the apex of the class structure and economically favoured the upper echelons and strata of South African society. ${ }^{69}$

An antidote to this state of affairs is the reintroduction of substantive uncertainty into the political system. Of course there may be much debate on the precise institutional mechanisms that could facilitate substantive uncertainty. Some might maintain that it need only involve electoral reform and the emergence of social movements ${ }^{70}$ while others suggest that it would require the former coupled with the break-up of the tripartite alliance and the abandonment of corporatist institutions. ${ }^{71}$ All of this could facilitate uncertainty, which is necessary to loosen the existing configuration of power in South African society. What it is important to note in this debate, however, is that none of the other elements except the presence of social movements exists or is likely to emerge in the foreseeable future. For now at least, social movements are the only hope for introducing substantive uncertainty and thereby facilitating the accountability of state elites to the citizenry.

It is instructive to note that the South African government's recent shift to a more state interventionist and expansive economic policy with a more welfarist orientation coincided with the emergence and heightened activity of social movements in South Africa. While it would be difficult to establish direct causality between the shift in state policy and the emergence of social movements, very few observers of the South African scene would deny that social movements contributed to the emergence of a political climate that encouraged state elites to become more responsive to the country's most marginalized

69 A. Whiteford \& D.E. Van Seventer, 'South Africa's changing income distribution in the 1990s', Studies in Economics and Econometrics, 24, 3 (2000), pp. 7-30.

70 R. Mattes \& R. Southall, 'Popular attitudes toward the South African electoral system', Democratization, 11, 1 (2004); Ballard, Habib \& Valodia (eds), Voices of Protest.

71 A. Habib \& R. Taylor, 'Political alliances and parliamentary opposition in postapartheid South Africa', Democratization, 8, 1 (2001); A. Desai \& A. Habib, 'Labour relations in transition: The rise of corporatism in South Africa's automobile industry’, Journal of Modern African Studies, 35, 3 (1997). 
citizenry. This shift in state policy is naturally not without problems and has as yet not gone far enough. ${ }^{72}$ It could also be argued that such shifts are the enlightened twin of the strategy of repression. For Harvey, drawing on Gramsci, ' $[t]$ he power of the hegemon ... is fashioned out of and expressed through an ever-shifting balance between coercion and consensus' ${ }^{73}$ Realizing that it has opened the door for others to gain support through more explicitly worded antipoverty manifestos, the ANC government shifted to recapture ground in the build-up to the 2004 election.

South Africa is again not unique in Africa in this regard. The one-party regimes of the post-colonial era were not very responsive to the interests of their citizens, corruption and patronage flowered, and elite interests predominated. These only came under sustained attack and political elites became more open to citizens when civil society coalesced in opposition or when violence erupted in society. The most recent demonstration of this is Zimbabwe. It was when the MDC emerged, itself a product of the NCA, that the Mugabe regime started to talk about the socio-economic rights of rural peasants. Of course ZANU-PF also resorted to violence, which spiralled the economy into crisis. Nevertheless, it is the challenge to one-party dominance as a result of social mobilization that has conditioned Zimbabwean political elites to be more socially responsive.

This pattern repeats itself time and time again across the continent: Zambia, Kenya, Nigeria, South Africa, Zimbabwe and many others are all examples of this political process. Recognition of it enables us to conclude that the effective operation of social movements is a necessary, if not a sufficient political condition to prompt a sustainable shift in state policy in the interests of South Africa's poor and marginalized. A more human-centred development trajectory and the consolidation of democracy require, in part, the systemic presence and effective functioning of contemporary social movements in South Africa.

72 A. Habib, 'The politics of economic policy-making: Substantive uncertainty, political leverage, and human development', Transformation, 56 (2004).

73 Harvey, The New Imperialism, pp. 37-38. 


\title{
African civil society, 'blood diamonds' and the Kimberley process
}

\author{
Lansana Gberie
}

'People are very angry. They want to say, 'God, why did diamonds be, you know...? Why did you let diamonds be put in Sierra Leone?' We do not know how come ... Sierra Leone with such a wealth can be, you know, in such a global mess.'

Abu Brima, National Coordinator, Network Movement for Justice and Development, Freetown, Sierra Leone; Interview with Voice of America (VOA), 13 January 2000.

The campaign against 'conflict' diamonds - those defined as having been illegally mined and sold by rebel armies to fund wars in Africa - was a singular phenomenon of NGO/civilsociety activism in Africa. Beginning inauspiciously with research by little-known and poorly funded groups, the campaign quickly attracted the attention of dozens of governments and the diamond industry and came to dominate discussions on the civil wars in Sierra Leone, Angola and elsewhere in Africa. It provided material and background for books, journal articles and academic dissertations, development programmes; an awardwinning song by the American rapper Kenye West; a major Hollywood blockbuster and several documentaries and films (including a Nigerian one). In both its intensity and effect, the 'conflict diamonds' campaign qualifies as a highly successful social movement - a campaign which, though loosely organized and coordinated, was sustained over a significant period of time and was geared towards specific social goals, namely economic and social justice and peace.

This chapter examines how the campaign started, the role of African civil-society groups in sustaining it and why it was so successful and led to sanctions against rebels in Sierra Leone and the Liberian government (thereby no doubt significantly 
helping the peace process in both countries). It was also involved in the introduction of the Kimberley Process Certification Scheme (KPCS) - a global, UN Security Councilendorsed system requiring the tamper-proof certification of all rough diamonds traded (worth annually at the time about US\$ 7 billion).

[The] high influx of foreign mining companies and the lack of pro-poor mining policies coupled with inadequate implementation mechanisms reinforce the powerlessness of the people and undermine their livelihood goals. Artisanal [diamond] mining is largely uncontrolled and uncoordinated resulting to [sic] high rate of smuggling, environmental hazards and poor living/working conditions. The government is largely promoting the economic agenda of the International Financial Institutions to the extent that the real livelihood needs of the poor are compromised in favour of foreign mining companies/investment. [Our] programme seeks to promote good corporate governance, environmental protection, community beneficiation and strict adherence to international standards.

Statement by the Just Mining Campaign, Freetown, 2001

The 'conflict' or 'blood' diamonds campaign effectively lasted for a little over three years, probably a shorter lifespan than any other comparable campaign in history. Largely because of its short duration, the highly successful social movement it generated as a global human-rights campaign was rather inchoate. Many observers and some of its leading participants primarily experienced its international dimension. As a movement, it was mainly driven by Western activists and NGOs and it led to the Kimberley Process Certification Scheme (KPCS), the international system of control for the movement of rough diamonds. From this vantage point, the campaign was of a largely intellectual nature, driven by well-researched reports, manipulation of media reporting, and high-level lobbying by NGOs and liberal Western politicians. What has been almost completely ignored in the assessment of the phenomenal success of the campaign is the great impetus that it enjoyed from the very beginning by the involvement of African NGOs operating in such troubled spots as Sierra Leone and Congo, ${ }^{1}$ two countries where resource-driven warfare came to attract massive international attention. In these two countries, the issue fed into important local concerns about social justice and economic development, and became a rallying ground for civil-society activists spearheading peace movements. As a

1 Following Crawford Young, I refrain from using the official designation 'Democratic Republic of Congo'. As Young writes, the 'democratic' title remains 'a grotesque misrepresentation of political practice,' making the designation 'Congo-Kinshasa' or simply 'Congo' the most appropriate in the circumstances. See Crawford Young, 'Contextualizing Congo conflicts,' in: John F. Clark (ed.), The African Stakes in the Congo War (Fountain Publishers, Kampala, 2002), p. 29. 
result, it gained enormous traction within a very short period, overtaking other rights-related international campaigns like those against residual forms of slavery in Sudan and the somewhat narcissistic campaign against the fur trade. It moved swiftly from accusations and denials to concrete steps taken by over 42 governments around the world and the UN Security Council to effectively address the problem, namely that diamonds mined illegally and traded internationally by anti-government or insurgent groups in Africa were being used to fund their violent campaigns. The steps introduced included sanctions against groups and countries held to be culpable and, more creatively, the launch of the Kimberley Process Certification Scheme (KPCS). The campaign was undoubtedly also the strongest influence in the indictment and subsequent trial for crimes against humanity and other offences, by the UN-backed Special Court for Sierra Leone, of Liberia's President Charles Taylor, the first African head of state to face such a judicial process.

In both its intensity and effect, the 'conflict diamonds' campaign clearly qualifies as a highly successful social movement, a campaign which, though loosely organized and coordinated, was sustained over a significant period of time and was geared towards the specific social goals of economic and social justice, and peace.

This chapter examines how the campaign started, the role of African civilsociety groups in sustaining it, and why it was so successful. It resulted in sanctions against rebels in Sierra Leone and the Liberian government (thereby no doubt significantly helping the peace process in both countries), and the KPCS, the global UN Security Council-endorsed system requiring the tamper-proof certification of all rough diamonds (worth annually about US\$ 7 billion) before they are traded internationally.

\section{How it started}

The term 'conflict diamonds' has gained such currency and evokes such passion that it is hard to believe that the issue was first brought to public attention in late 1998 by Global Witness, a small British NGO operating from an untidy office in London. The group's chief campaigner was a young London former disc jockey with a taste for designer suits - Miami Vice rather than Savile Row. The group had been investigating the illegal timber trade in Cambodia - from which the murderous Khmer Rouge guerrillas were making US\$ 20 million a month at its height in the early 1990s - but in 1998 it turned its attention to Angola, a state ravaged by decades of bloody warfare. In a report entitled 'A Rough Trade' ${ }^{2}$ that was released in December 1998, Global Witness reported that the

2 Global Witness, 'A Rough Trade: The role of companies and governments in the Angolan conflict', 
National Union for the Total Independence of Angola (UNITA), a rebel group with a reputation for psychotic brutality that then controlled over $60 \%$ of Angola's rich diamond reserves, had generated US\$ 3.7 billion between 1992 and 1998 to underwrite its war effort, effectively making it one of the most profitable business enterprises in Africa. ${ }^{3}$

The disclosure was significant in more ways than one. The Angolan war had started as a war of liberation in the late 1960s and, after independence in 1975, morphed into a full-scale 'ideological' war with important Cold War implications. With the end of the Cold War and with it the loss of American and later South African support, UNITA, led by ex-Maoist Jonas Savimbi, seemed to have lost political justification and support for continued warfare. UNITA's campaigns effectively devolved into banditry, and Global Witness's findings made it clear that diamonds had become the main explanation for the continuing violence in Angola, as the principal source of funding for UNITA. Pillage rather than politics had become a goal of warfare. This violence had led to the deaths of nearly one million Angolans, the displacement of millions more, and had rendered a potentially wealthy country into one of the most miserable, not to say dangerous, in the world. ${ }^{4}$

At the time that Global Witness published its report, the South African-based De Beers, which controlled about $80 \%$ of the global rough diamond trade, had been boasting about its ability to mop up diamond supplies from even unstable areas like Angola, and continued to buy offices in Guinea, the Democratic Republic of the Congo (DRC) and elsewhere in Africa. This meant that technically it could not deny buying diamonds from a group like UNITA. Global Wit-

(http://www.globalwitness.org/media library detail.php/90/en/a rough trade,

December 1, 1998).

3 The US\$ 3.7 billion figure is, of course, a guesstimate, but a reasonable one. Christopher Cramer, who has attempted to present a more nuanced picture of the reasons for the continuation of the Angolan war (rather unsuccessfully, in my view) suggests that the cumulative revenue from diamonds traded by UNITA from 1989 to 1998 was 'probably US\$ 2-3.5 billion'. To put this figure into perspective, Cramer notes that the Reagan-era US aid to UNITA 'peaked around US\$ 40-60 million a year between 1989 and 1991'. Though critical of the overly economistic interpretation of the war, Cramer notes that even Angolan army officers (technically at war with UNITA) and 'running supply businesses in the Lundas would trade openly with UNITA diamond bosses, selling and exchanging goods across a river that was also a frontline'. See Cramer, Civil War is not a Stupid Thing: Accounting for violence in developing countries (Hurst and Co, London, 2006), p. 155.

4 On the devastating impact of the Angolan war, see Inge Brinkman, 'Angolan civilians in wartime, 1961-2002,' in John Laband (ed.), Daily Lives of Civilians in Wartime Africa: From slavery days to the Rwandan genocide (Greenwood Press, London, 2007), pp. 169-194. 
ness was unequivocal about the purpose of its publication. Its intention, it stated, was 'to stimulate debate and action on a well known and much reported issue: the key role that diamonds have played in the Angolan conflict in the last ten years'. It added that:

[there] is a dangerous acceptance amongst the international community that the mechanics of the trade in diamonds, particularly from UNITA controlled areas, are beyond any real controls. Global Witness investigations show that governments flout the United Nations Security Council (UNSC) embargo on unofficial Angolan diamonds (those not sold under the control of the Angolan government diamond parastatal, Endiama). ${ }^{5}$

Global Witness's report quickly elicited denials and prevarications and, because the Angolan war had complex origins, the objection that diamonds were only incidental appeared reasonable to some. ${ }^{6}$ The issue was, however, taken up by others and the focus was then on a war where criminality was easy to establish: the Revolutionary United Front's (RUF) war in Sierra Leone. This chapter focuses on this particular conflict and how it shaped (and was in turn shaped by) the 'conflict' diamonds campaign.

\section{The heart of the matter}

From 1991 Sierra Leone suffered devastating attacks by the Revolutionary United Front (RUF), a uniquely brutal rebel group that used terror tactics, like amputations, to force the mass displacement of people and the occupation of productive areas of the country for the sole purpose of pillage. The country's rich alluvial diamond reserves were among its early targets. By 1998, the RUF's

5 Global Witness, 'A Rough Trade'. The Global Witness report was supported by a UN Panel of Experts report on Angola less than two years later. Headed by Canadian diplomat Robert Fowler, the panel documented UNITA's extensive network of support and collaboration with shady business people and some African governments. The report, released in March 2001, estimated UNITA's diamond trade as being worth between US\$ 3 billion and US\$ 4 billion between 1992 and 1998. The report noted that diamonds played 'a uniquely important role within UNITA's political and military economy'. See Section 111 (1) 77 "The Significance of Diamonds for UNITA" (http://www.un.org/News/dh/latest/angolareport eng.htm, September 22, 2008).

6 Ibid. The Fowler Report noted three reasons why diamonds were so important to UNITA's ability to continue its deadly operations: 'First, UNITA's ongoing ability to sell rough diamonds for cash and to exchange rough diamonds for weapons provide the means for it to sustain its political and military activities. Second, diamonds have been and continue to be an important component of UNITA's strategy for acquiring friends and maintaining external support. Third, rough diamond caches rather than cash or bank deposits constitute the primary and the preferred means of stockpiling wealth for UNITA'. 
campaign had caused the death of upwards of 50,000 people, displaced twothirds of Sierra Leone's population of about 5 million and destroyed over half of the country's already limited infrastructure. Yet little was known of this war in the wider world. Throughout the 1990s the RUF was a mysterious, deadly force and its leader, a cashiered army corporal called Foday Saybanah Sankoh, only a disembodied and inarticulate voice that was occasionally heard on the BBC African Service. Areas under its control were inaccessible to outsiders, including journalists. Consequently, RUF violence was simply dismissed as 'senseless' and, therefore, incomprehensible.

After a particularly devastating attack on Freetown in 1999 by the RUF and its allies of renegade soldiers from the Sierra Leonean Army, Partnership Africa Canada (PAC) decided to do a study of the war for the purpose of policy advocacy. The group's three researchers adopted the methodology used by Global Witness to understand the Angolan conflict and focused on the RUF's looting of Sierra Leone's vast alluvial diamond fields. The reasoning behind this was that the rebel group had not articulated any coherent political platform, was completely devoid of ethnic or regional support, and appeared viable only because it had access to significant resources - as yet not fully determined - with which it was underwriting its campaign.

The result was 'The Heart of the Matter: Sierra Leone, Diamonds and Human Security', ${ }^{7}$ which was launched simultaneously in Ottawa (Canada) and Freetown (Sierra Leone) in January 2000. The launch was the result of an ingenious strategy that came to sustain the campaign and make it so effective: it involved active collaboration between the Canadian-based group and an influential Sierra Leonean-based NGO called the Network Movement for Justice and Development (NMJD). NMJD had been established in 1998 with the aim of 'promoting justice and sustainable development at all levels in society' and was coordinated by Abu Brima, an outspoken, not to say militant, long-term activist who hailed from Kono, Sierra Leone's main diamond district, and a place despoiled by largely unregulated mining activity. Collaboration between his group and the Canadian-based PAC was forged during the research, and continued throughout the campaign and beyond. The Canadian-based authors participated by telephone during the launch of the report in Freetown in a live radio discussion of the report and its recommendations. This was organized by NMJD

7 Ian Smillie, Lansana Gberie \& Ralph Hazleton, The Heart of the Matter: Sierra Leone, diamonds and human security (Partnership Africa Canada, Ottawa, 2000). The title is borrowed from the novel by Graham Greene, who was a British secret service agent posted in Sierra Leone during the Second World War. Greene investigated suspicions that diamonds from the then-British colony were being smuggled to Germany through Vichy French territory (neighbouring Guinea). 
and is an indication of the crucial role that the mass media can play in such campaigns.

The PAC report was an attempt to understand the war, not the diamond industry itself. However by examining the role of diamonds in the political economy of Sierra Leone in the context of the war, the report was able to trace the long and slow corruption of Sierra Leone's diamond industry since the stones were first commercially exploited in the country in the 1930s. It showed that mainly through illicit mining and smuggling, in which Sierra Leone's successive leaders from the British colonial overlords to the country's postindependence leaders colluded, diamond exports dropped from a peak of two million carats a year in the 1960 s to less than 50,000 carats by 1988 . Sierra Leone's populist president during most of this period, a former trade-union leader named Siaka Stevens, tacitly encouraged illicit mining and he himself became involved in criminal or near-criminal activities. The RUF's rebel war began in 1991 and, from the outset, Charles Taylor, the Liberian warlord and later president who helped train and launch the rebel group, acted as a supplier of weapons, diplomatic supporter, banker, trainer and mentor to the RUF.

The report claimed that the rich alluvial diamond fields of Kono District and Tongo Field were among the RUF's earliest and most prized targets and argued that diamonds were a key part of Taylor's calculation. 'The Heart of the Matter' concluded that:

... only the economic opportunity presented by the breakdown of law and order could sustain violence at levels that have plagued Sierra Leone since $1991 \ldots$ it is ironic that enormous profits have been made from diamonds throughout the conflict, but the only effect on the citizens of the country where they are mined has been terror, murder, dismemberment and poverty.

The PAC report showed conclusively that there was virtually no oversight of the international movement of diamonds and that, during the 1990s, billions of dollars worth of diamonds were imported into Belgium from Liberia, even though Liberia produces very few diamonds itself. Big companies and small were colluding in the laundering of stolen diamonds. The same was true of Congo Brazzaville, which is conveniently adjacent to Congo Kinshasa, and which also mysteriously became a major diamond producer. UNITA too, as Global Witness had noticed, financed much of its war in Angola through the sale of diamonds and traded with impunity throughout Africa and Europe.

The report's key argument was that diamonds had, in the course of the long war, become indispensable for the RUF: the gems in Sierra Leone were mainly of an alluvial nature which meant that they were widespread and easily mined. Their trade was highly unregulated internationally. Lacking political support and a motivating ideology, the RUF was able to enhance its power and political 
significance by criminally expropriating these valuable resources to acquire weapons and hire mercenaries.

By laying bare the political economy of Sierra Leone's decade-long war, the PAC report found an explanation for the dynamics of the conflict and the reasons for its intensity, apparent 'senselessness' and almost intractable nature. The explanation helped to shift discussion of the war, in academic, journalistic and policy-related circles, away from complacent and somewhat racialist explanations evoking notions of mindless African savagery and nihilism to more easily grasped and appreciated preoccupations: resource exploitation, criminal appropriation and power.

\section{NMJD and CENADEP}

While the international dimension of the trade was the galvanizing element for Western NGOs and researchers, the more immediately important and tangible issue for Brima's NMJD was related to internal governance: official corruption, the lack of proper regulatory mechanisms in Sierra Leone, and the tendency for local politicians to protect foreign companies or mining interests at the expense of the long-suffering indigenous population. NMJD declared its position on internal governance in Sierra Leone in these searing terms:

Corruption is endemic in Sierra Leonean society; all sectors ranging from the central government right down to local communities have been affected by high levels of corruption. This is manifested in mismanagement of national resources, weak capacity of service providers and lack of monitoring and punitive mechanisms to discourage perpetrators of corrupt practices. This has led to a culture of impunity. There is also an apparent lack of responsiveness of successive governments to the needs and aspirations of the populace (irresponsible leadership). ${ }^{8}$

In September 2000 and working through its Just Mining Campaign that had been launched immediately after the release of 'The Heart of the Matter', NMJD convened a National Consultative Conference on diamond mining in Sierra Leone. It brought together hundreds of civil-society activists from all over the country but particularly from the diamond-mining areas, dozens of artisanal miners, chiefs, journalists and some politicians. The main topics on the agenda were: security ('rebel control of major mining areas and how to gain control of those areas'); the role of the government in diamond mining; the impact of mining on the environment; the generation and distribution of revenue from mining; the role of civil society in framing mining policy; the cultural dimension of diamond mining; and, lastly, the international dimension of diamond mining (with 'a healthy international environment favourable to peace

8 Position paper issued by NMJD in 2000, shortly after the launch of 'The Heart of the Matter' (in this author's possession). 
and development'). Among the key resolutions was a ban on diamond mining for five years until all mining areas had been liberated from rebel control and proper regulations had been put in place; the declaration of a UN trusteeship over diamond-mining areas; the removal of all foreigners from mining areas and a new definition of citizenship for those who were to have access to diamondmining areas restricted 'by birth and not by ownership of Sierra Leonean passport'; and, the allocation of $10 \%$ of government royalties on diamonds to mining communities for 'community development programmes'. Civil society, led by the Just Mining Campaign, was to play an active role in shaping government policy towards mining. ${ }^{9}$

Brima explained what followed:

[Our] aim was ensuring that the Sierra Leone diamond industry operates legally, openly, and for the benefit of Sierra Leoneans - diamonds must become an asset, rather than a detriment, to peaceful long-term development. [We demand] that the country and the [diamond] industry adopt a human rights framework in mining policy formulation and implementation. In the past, mining was the preserve of government and a few individuals, mainly foreign nationals. The [Just Mining] Campaign had to develop new ways to incorporate civil society. This entailed innovative strategizing. To empower the people and make them owners and beneficiaries of their resources, we formed alliances with numerous sectors of civil society, educated the public, and confronted those with a vested interest in maintaining the status quo.

The first step was to establish task force coalitions of civil society groups all over the country. After significant outreach, task forces comprised of human rights groups, environmental organizations, academic institutions, the Bar Association, student and trade unions, community development organizations, individual activists, theatre groups, youth, nurses, and women's groups began to develop. The establishment of task forces - at the national, provincial, and ... district levels allows for participatory structures for education, mobilization, and action on mining issues. The rights of the people to participate fully in policies and decisions affecting their lives are essential to establishing accountability and social responsibility in the mining industry and to curtailing the abundance of weapons of war bought with the proceeds from minerals. ${ }^{10}$

In this effort, 'expanding and strengthening strategic alliances with international organizations was essential,' Brima wrote. 'The task force coalitions worked in close collaboration with international groups such as Partnership Africa Canada, Global Witness, International Peace Information Service, Action Aid, Oxfam, and Amnesty International. This collaboration focused international attention on the issue of conflict diamonds and elevated the struggle to an

9 See (http://www.sierra-leone.org/nmjd093000.html, January 2009).

10 Abu Brima, 'Mining for the People', Human Rights Dialogue, (http://www.cceia.org/resources/publications/dialogue/2 09/articles/945.html, February 9, 2003) 
international level.' Brima's account is a welcome corrective because the global coverage of the 'blood diamonds' issue - for example, the Hollywood production Blood Diamond featuring Leonardo DiCaprio, Djimon Hounsou and Jennifer Connelly - tended to portray the campaign as entirely Western-driven, with Africans appearing simply as props. As a result of the Just Mining Campaign, the Sierra Leone government established the Diamond Area Community Development Fund, assigning part of the proceeds from the export tax on diamonds to the development of mining communities, and legislated to streamline the cumbersome process for obtaining mining licenses and make the industry more transparent.

Thousands of miles away from Sierra Leone, in Central Africa, the Centre National d'Appui au Développement et à la Participation Populaire (CENADEP) was trying to grapple with the effects of the far more complicated and tragic conflict in Congo (Kinshasa). It was inspired by the work of PAC and NMJD to become the focal point for a civil-society Natural Resources Network. The group began in 2002 by monitoring the exploitation of natural resources, in particular diamonds, in Congo as well as investigating issues of transparency and (human) security in the extractive economy. ${ }^{11}$ The programme was financially supported by Partnership Africa Canada and aimed to contribute to 'the search for a lasting peace and the development of the Congo by combating illegal and criminal practices in sectors that have been at the root of conflicts in the country: extractive mining and the exploitation of natural resources'. Within two years, CENADEP was able to establish focal points in every province in the vast and logistically challenging Congo. It also developed an advocacy campaign at national and international levels. By 2003, it was undertaking activities, such as conferences, debates and roundtable discussions, with the government on issues relating to the management of natural resources. It was also leading missions to various provinces for research and the dissemination of information, as well as producing a documentary on diamond dealers in Kinshasa. ${ }^{12}$ In January 2009, when this author visited Hamuli in CENADEP's offices in Kinshasa, the group was still working on the issue of resource management and maintaining programmes around artisanal mining in two provinces in Congo. However in such a vast and complicated country, progress like that achieved in Sierra Leone by NMJD appeared to be elusive and parts of the country, in particular the diamond-rich eastern regions, were still enmeshed in war. Issues of governance appeared to be secondary to the more urgent task of ending the fighting, disarming tens of thousands of combatants and unifying the country.

11 Interview with Baudouin K. Hamuli, Director-General of CENADEP, Kinshasa, January 2009.

12 See Partnership Africa Canada's Year in Review 2002-2003 (www.pacweb.org, January 2009). 


\section{Britain, Canada and the UN}

The impact of 'The Heart of the Matter', mainly due to the widespread and compelling publicity it received in the international media, was especially dramatic in some Western capitals. Canadian Foreign Minister Lloyd Axworthy, who had made human security the linchpin of his policy, welcomed the report and used it in his extensive advocacy on behalf of Sierra Leone in the UN Security Council and elsewhere. In quick order, his department organized a oneday seminar on the economic dimensions of civil war, to which he invited the authors of 'The Heart of the Matter' (this author was the rapporteur) and leading scholars interested in the issue, and appointed David Pratt, an MP (and subsequently Defence Minister), as Special Envoy for Sierra Leone. This was a role that allowed the Canadian government to become more actively involved in the Sierra Leone peace process and play a central role in the debate about reforming the corrupt international diamond industry.

The British government, Sierra Leone's most important foreign ally and biggest aid donor, took the report equally seriously. Shortly after it was launched, British Foreign Office Minister Peter Hain visited Sierra Leone, where he referred to the report in a stirring speech to parliamentarians and civilsociety activists:

I am determined to look for ways to stamp out the theft of Sierra Leone's diamonds, and the way they have been used to fund conflict. [...] Why is it that the government of Sierra Leone derives almost no revenue from diamond sales? And why am I being told that the Liberian annual diamond exports are beyond its diamond mining capacity?

In London a week later, Hain told UK government officials that the RUF's access to the diamond fields was the key reason for the lack of progress in the Sierra Leone peace process and called for an aggressive UN military deployment in those areas:

I want to see the United Nations peacekeepers, in particular the Indian contingent which I saw camped at the main airport outside Freetown, deployed across the country where they ought to be, which is the eastern side of the country where the RUF rebel combatants have been, and are still in large numbers, where the diamonds are and where a lot of trouble has occurred. ${ }^{13}$

The first attempt by a UN contingent to deploy in the areas was botched a few months later, leading to the capture of hundreds of UN troops by the RUF. A UN Panel of Experts was appointed by the Security Council shortly after this debacle to investigate 'the link between trade in diamonds and trade in arms and

13 Quoted in Lansana Gberie, A Dirty War in West Africa: The RUF and the destruction of Sierra Leone (Hurst and Co., London, 2005), p. 186. Part of this section is drawn from Chapter 8 of this book. 
related materiel' that was helping to sustain the RUF war effort. It found conclusively that diamonds constituted 'a major and primary source of income for RUF' in 'sustaining and advancing its military ambitions'. The panel released its report in December 2000 stating that the 'bulk of the RUF diamonds leave Sierra Leone through Liberia', whose president, Charles Taylor, sold them to dubious contacts, pocketed most of the proceeds and arranged weapons and other deals (including drug purchases) for the RUF. The United Nations estimated the RUF's diamonds exports as being 'from as little as US\$ 25 million per annum to as much as US\$ 125 million per annum'. ${ }^{14}$

The UN report was solid amplification of the PAC findings, and after its release, the UN General Assembly immediately adopted the resolution with the aim of breaking the link between rough diamonds and conflict in Africa. The Security Council soon imposed targeted sanctions on Liberia and the RUF, and similar sanctions were also imposed on Sierra Leone's diamonds until a UNmonitored certification system was introduced in September 2000. Perhaps the most interesting finding in the PAC report, from the point of African activists and Western NGOs, was that there was virtually no oversight on the international movement of diamonds: the diamond business was shrouded in total secrecy that suggested massive levels of corruption. A previous report by a UN Panel of Experts on Angola - the Fowler Commission's report that was issued in March 2000 - had drawn similar conclusions. It noted that the diamond industry:

... [had] failed to establish an effective import identification regime with respect to diamonds. Nor has any effective effort been made to monitor the activities of suspect brokers, dealers and traders - virtually all of whom appear to be able to travel freely and operate without hindrance...

The unwillingness or inability of the diamond industry, particularly in Antwerp, to police its own ranks is a matter of special concern to the Panel. Persons known within the industry to be dealing in UNITA diamonds have as a general rule neither been exposed by the industry, nor subjected to any sanction by the industry ... Lax controls in some producing countries may enable UNITA diamonds to be passed off as diamonds of different origin, and a number of countries that do not produce any diamonds still export rough diamonds as originating from their territory. Moreover, diamonds on the open market have traditionally been handled without controls as to the origin, and it has been sufficient merely to record provenance, i.e. where the diamonds have been shipped from as they arrive at the markets. It can sometimes be difficult for the countries of destination to differentiate between the countries of provenance and origin. ${ }^{15}$

Liberia was one of the most glaring examples of a place where this kind of laundering was happening, but other countries were also apparently complicit.

14 Ibid., p. 186.

15 http://www.un.org/News/dh/latest/angolareport eng.htm, March 10, 2000. 
The Gambia, for example, was found by the UN panel on Sierra Leone to have been the source of diamonds worth US\$ 500 million traded on the Antwerp markets over the years, even though the country produces no diamonds whatsoever. Clearly a great deal of diamond laundering was going on. This finding, as suggested by the Fowler Report, triggered interesting arguments about the 'origin' and 'provenance' of diamonds, an issue settled only by the Kimberley Process Certification Scheme (KPCS), a system that significantly helped to curtail the flow of money to rebel and associated groups in the region and beyond, thereby helping to end the war.

\section{Primary resources and conflict}

It is important at this point to underline the intellectual context in which the 'conflict' diamonds campaign thrived. At the end of the 1990s, an interesting debate on the economic dimensions of violent conflict in Africa gained huge momentum. Perhaps the most influential product was 'Greed and Grievance: Economic Agendas in Civil Wars ${ }^{16}$ and a World Bank report ${ }^{17}$ that was a somewhat more detailed and dramatic illustration of the key points of 'Greed and Grievance' and argued that:

While objective grievances do not generate violent conflict, violent conflict generates subjective grievances. This is not just a by-product of conflict, but an essential activity of a rebel organization ... The task in post-conflict societies is partly, as in pre-conflict societies, to reduce the objective risk factors. However, post-conflict societies are much more at risk than implied by the inherited risk factors, because of this legacy of induced polarizing grievance. Either boundaries must be re-established between the political contest and violence, or the political contest must be resolved. Neither of these is easy, which is why, once a civil war has occurred, the chances of further conflict are so high.

Perhaps in no other conflict in Africa could Collier's depressing analysis better apply than to the bloody rebel war in Sierra Leone. Beginning as armed incursions from Liberia, the conflict devolved into a savage civil war in which the RUF, backed by Taylor, wreaked havoc primarily on civilians in the countryside and gained control of the alluvial diamond-rich regions of eastern and southern Sierra Leone. Understanding the predatory nature of the Sierra Leone war took some time but once this had happened, efforts to end it, including UN

16 Mats Berdal \& David Malone (eds) \& International Peace Academy (IPA), Greed and Grievance: Economic Agendas in Civil Wars (2000).

17 Paul Collier, 'Economic causes of civil conflict and their implications for policy', World Bank (www.worldbank.org/research/conflict/papers/civilconflict.htm). Collier has published a more nuanced version in The Bottom Billion: Why the poorest countries are failing and what can be done about it (Oxford University Press, Oxford, 2007). 
sanctions on diamonds and timber, accelerated. Thousands of UN troops had to be deployed to disarm the militia factions, help the state restore normative order and curb the widespread criminality the war had helped trigger.

William Reno was probably the first scholar to emphasize the economic motives of insurgents spearheading the war in Sierra Leone, which he correctly saw as being intimately linked to Charles Taylor's insurgency (preferring the term 'warlordism') in Liberia. He argued that the key driver of the conflicts was Taylor's continued looting of Liberia's hardwood timber, and his access to Sierra Leone's diamond reserves. Warfare in this view was simply profitable theft: pillage rather than politics was the key driver of the conflict. ${ }^{18}$

A number of salient issues tended to support this view. Firstly, although the corruption and irregularities of Sierra Leone clearly helped set the stage for its unravelling in the 1990s, the violent RUF was certainly not motivated by any evident desire for social justice or a wish to reconfigure the country in ways that would make it more responsive to its overall citizenry. In other words, governance and democracy were not the issues. The spread of violence and its perpetuation undoubtedly had more to do with the weaknesses and failure of the state the insurgents took on than with any mass appeal or intrinsic strength enjoyed by the RUF. The grievances of the majority of the people against the estranged elites in the capital city were real but there is no evidence that the insurgents represented those grievances in any meaningful sense.

Secondly, the RUF, as mentioned earlier, was desperate from the start to latch on to and exploit the diamonds, Sierra Leone's primary resource, that were abundant in the country's vast alluvial fields. This desperation became an obsession. In the end, whatever high ideals some of the insurgents might have held, the control and exploitation of diamonds became their primary motivation. According to the UN, the RUF made millions of dollars from the illegal exploitation of diamonds, money that served mainly to enrich the rebel leaders.

Perhaps most importantly, the RUF targeted mainly civilians, rather than any armed opponents, and there was little or no attempt to win over the general populace. There was no systematic political programme that would appeal to the general citizenry, nor any coherent ideology that might serve to provide insight into what the insurgents would do once they gained power. When they temporarily took power at the invitation of rogue soldiers in 1997, the result was continued pillage, violence and destruction, and a total inability to set up any stabilized form of governance. Indeed the behaviour of the RUF in power was so wanton and destructive that hundreds of thousands of Sierra Leoneans fled the country and there were mass protests and nationwide anti-government

18 William Reno, Warlord Politics and African States (Lynne Rienner Publishers, Boulder, CO, 1998). 
demonstrations. The regime was ostracized by the international community, with no country at all opting to recognize it. This gave Nigeria, as the regional power, the impetus to work with a growing civil defence group in February 1998 to oust the junta - the Armed Forces Ruling Council (AFRC) - of which the RUF was an integral part. Once out of power, the rebels regrouped and, aided by the capture of the diamond-rich Kono district, re-armed and launched a devastating attack on Freetown in January 1999. The attacks led to another round of negotiations with the government that were brokered by the UN and the US and led to the Lomé Peace Agreement in July 1999. This agreement instantly became notorious for granting general and unconditional amnesty to the RUF as well as, even more outrageously, control of the country's diamond mining to its leader, Foday Sankoh.

\section{The Kimberley Process}

The 'blood diamonds' campaign quickly came to include a wide and diverse cast of characters - academic researchers associated with Western NGOs and think tanks; freelance writers and journalists; traditional human-rights groups and Western NGOs and advocacy groups like Partnership Africa Canada (PAC), Global Witness, Amnesty International, Human Rights Watch, Oxfam, World Vision and Action Aid; African civil-society groups like NMJD and CENADEP; politicians and diplomats; and, later, movie stars and awardwinning musicians. The stakes, at least from the point of view of the campaigners and many others, were very high and involved the lives of millions of Africans. Ian Smillie, a Canadian development specialist who was research coordinator for Partnership Africa Canada, put it in these dramatic terms:

Conflict diamonds have contributed to the deaths of hundreds of thousands of people over the past decade. They have fuelled wars; they have led to massive civilian displacement and the destruction of entire countries. They have capitalized on the much larger traffic in illicit diamonds that are used for money laundering and tax evasion, or are simply stolen from their rightful owners. While conflict diamonds represent a small proportion of the diamond trade, illicit diamonds represent as much as 20 per cent of the annual world total ... This level of illegality created the opportunity and the space for conflict diamonds, and regardless of how current conflicts unfold, it will continue to present a threat to peace and stability in Africa. Conflict diamonds are a major human security problem, and illicit diamonds are their spawning ground. ${ }^{19}$

The sense of urgency that the campaign represented was captured even in the sedate language of the United Nations. At the height of the 'blood' diamonds

19 Ian Smillie, The Kimberley Process: The case for proper monitoring (Partnership Africa Canada, Ottawa, Occasional Paper 5), 2002. 
campaign, in December 2000, the United Nations General Assembly unanimously adopted Resolution 55/56 on the role of diamonds in fuelling armed conflict in Africa with a view to 'breaking the link between the illicit transaction of rough diamonds and armed conflict, as a contribution to prevention and settlement of conflicts'. It noted that the General Assembly:

recognize[s] that conflict diamonds are a crucial factor in prolonging brutal wars in parts of Africa, and underscored that legitimate diamonds contribute to prosperity and development elsewhere on the continent. In Angola and Sierra Leone, conflict diamonds continue to fund the rebel groups, the National Union for the Total Independence of Angola (UNITA) and the Revolutionary United Front (RUF), both of which are acting in contravention of the international community's objectives of restoring peace in the two countries. ${ }^{20}$

The UN defined 'conflict diamonds' as 'diamonds that originate from areas controlled by forces or factions opposed to legitimate and internationally recognized governments, and are used to fund military action in opposition to those governments, or in contravention of the decisions of the Security Council' ${ }^{21}$ Estimates of 'conflict diamonds' were put at between $4 \%$ and $15 \%$ of the world's total at different times. In purely financial terms, this was clearly important because even the low figure represented a significant volume of cash in impoverished Africa when set against the US\$ 7.5 billion annual trade in rough diamonds. In fact, it was estimated that as much as $20 \%$ of the world's rough diamond trade was illicit in nature and characterized by theft, tax evasion and money laundering. ${ }^{22}$

Meetings leading to the KPCS began in May 2000 when South Africa's Minister of Minerals and Energy, concerned about the threat to the legitimate industry posed by growing media and NGO publicity around 'blood' diamonds, convened a conference of interested parties, including De Beers, other diamond consortia, governments and NGOs, in Kimberley, the home of South Africa's first diamond mines. A month before the meeting, Minister Phumzile MlamboNgcuka (who later became Thabo Mbeki's deputy president) visited Canada and requested a meeting with the authors of 'The Heart of the Matter'. This author had an hour-long meeting with her and members of South Africa's powerful trade unions at the South African consulate in Toronto. The Minister, the embodiment of charm itself, stressed that her government was very concerned about the role that diamonds were playing in conflicts in parts of Africa but insisted that diamonds were playing a far more positive role in South Africa and Botswana. She mentioned that the livelihood of tens, if not hundreds, of thousands of people in her country and elsewhere depended on the diamond industry

20 http://www.un.org/peace/africa/Diamond.html, September 22, 2008.

21 Ibid.

22 Smillie, The Kimberley Process: The case for proper monitoring. 
(a point stressed by the trade-union representatives) and that, as a result of these two considerations, South Africa was spearheading a process to try and put an end to the 'conflict' diamond business and make the industry clean. 'Let's try this process first,' she urged, 'and if it doesn't work, you can then, as we say in South Africa, "go into the bush", ${ }^{23}$ The PAC report had, in fact, suggested this kind of engagement but raised the spectre of a consumer campaign, and not a boycott. This implicit threat appeared to be enough: an opening for engagement with governments and the industry had been sedulously created and it was now being taken up by a powerful player in the diamond industry.

PAC (as well as Global Witness) duly received an official invitation from the South African government to the May 2000 meetings in Kimberley. Negotiations were held with governments, the diamond industry and NGOs on the creation of a global certification and monitoring system. The Kimberley meeting was followed by another in Luanda (Angola) in June and a third in London in July. Although the NGO presence at these early meetings was at first limited to PAC and Global Witness, other far more powerful groups, like Amnesty International, Oxfam International, a European 'Fatal Transactions' consortium and representatives of a coalition of 80 American NGOs, including all the major US church organizations and led by World Vision and Physicians for Human Rights, began to attend the meetings of the Kimberley Process (as it came to be known).

In the year the process started, the international diamond industry produced more than 120 million carats of rough diamonds with a market value of US\$ 7.5 billion. At the end of the diamond chain this would be converted into 70 million pieces of jewellery worth close to US\$ 58 billion. The big South African company De Beers purchased by far the majority of the rough diamonds, and could more or less set the price. But other important players were emerging which made the process of regulation more urgent. In fact, it would emerge that countries engaged in cutting, polishing and trading polished (not just rough) diamonds needed to be brought on board as well. In 2000, for example, Israel exported US\$ 5.3 billion in polished diamonds to the US, India US\$ 2.5 billion and Belgium US\$ 2.4 billion. ${ }^{24}$

A month after the first Kimberley Process meeting, an iconoclastic diamond trader and publisher of an influential journal on diamonds, Martin Rapaport, visited Sierra Leone. A mercurial and flamboyant American with diamond

23 The expression was widely used during the struggle against apartheid to refer to guerrilla or violent conflict or insurgency, and the minister was alluding to threats by some NGOs - emphatically not including PAC - to mount a campaign for a consumer boycott of diamonds.

${ }^{24}$ Ian Smillie \& Lansana Gberie, 'Dirty Diamonds and Civil Society' (paper written for Civicus, 2001). 
interests in Israel, Antwerp and elsewhere, Rapaport published a feisty and widely circulated article entitled 'Guilt Trip' on his return in which he cursed 'the bastards [who are] not just stealing [Sierra Leone's] diamonds' but are also 'trading them for guns'. The real challenge facing Sierra Leone and the world diamond trade, he wrote, 'is how to stop this horrific murderous cycle of illegal diamond activity'. ${ }^{25}$ Rapaport posted 'The Heart of the Matter' report on his website in its entirety.

It was in this overheated climate that the RUF made the disastrous error, in May 2000, of attacking and capturing over 500 UN peacekeeping troops, killing some in the process. Civil-society groups in Sierra Leone, many of whom were now active in the campaign against the conflict and who had long been inflamed by the foolishness of the 1999 Lomé Peace Agreement that had given control of the diamond industry as a bribe to Foday Sankoh to encourage his participation in the peace process, mounted a massive demonstration in front of Foday Sankoh's villa. Sankoh's bodyguards responded by firing live bullets at the unarmed crowd, killing 19 people including a journalist. The world's media descended on Sierra Leone after this outrage and the forgotten war quickly dominated newspaper front pages and news broadcasts around the world. The events were almost unanimously described as 'The Diamond War'.

Pressure was also emerging from other powerful and influential sources. After a visit to Sierra Leone in December 1999, US Congressmen Tony Hall and Frank Wolf - a Democrat and a Republican respectively - introduced a bill in the House of Representatives aimed at preventing the flow of illicit or 'conflict' diamonds into the United States. And after the launch of the PAC report in January 2000, Canadian Foreign Minister Lloyd Axworthy decided to use Canada's position on the UN Security Council to expand the diamond discussion from a narrow focus on Angola to one that would embrace the issues in Sierra Leone as part of his focus on human security. Axworthy would himself make a well-publicized visit to Sierra Leone later.

Shortly after the Kimberley Process meetings started, a joint Belgian/UK/US mission to Sierra Leone was undertaken to develop an experimental tamperproof certification system for rough diamonds, the details of which were approved by the UN Security Council in August 2000. Just prior this, the World Diamond Congress was held in Antwerp from 17-19 July. Normally devoted to the technical and commercial aspects of the industry, this Congress was almost entirely given over to the issue of conflict diamonds. Representatives from governments and NGOs, including PAC, participated and the industry agreed on reforms that would represent the most fundamental set of changes it had ever tried. It called, for example, for 'redline' legislation in all countries that im-

25 Ibid., p. 4. 
ported diamonds as producers, manufacturers or dealers. Banks, insurance companies, shippers and others would be included in the system. A World Diamond Council was proposed and subsequently inaugurated to help move the process forward. The industry proposals were taken to government meetings in London in July 2002, the third in the Kimberley Process and, as before, NGOs were also present. The London meetings were followed by two days of hearings at the Security Council's Sierra Leone Sanctions Committee to explore the connection between diamonds and guns in the war. Of great significance was the fact that the hearings included testimony from governments, the diamond industry and individual experts. The Council refused to invite NGOs like PAC because some member nations objected to their presence but some of the strongest language up to that point on the issue of conflict diamonds was added to the record by 'individual experts' from PAC, Global Witness, Amnesty International and others. A noteworthy feature of the hearings was that, for the first time in the UN's history, a hearing of this nature was open to the public and was widely reported on.

About forty countries and dozens of NGOs continued to meet for a couple of years after the first meeting in Kimberley in 2000 but tensions between governments and NGOs became apparent at a meeting in Brussels in April 2001 when the NGOs expressed their frustration with delays in creating a global certification system in a widely circulated press release that noted disappointment over the 'lack of progress in efforts to end the trade in conflict diamonds'. The NGOs continued:

Further stalling and inaction will damage the credibility and the viability of the diamond industry, and the jobs it provides for hundreds of thousands of people. More importantly, it will allow rebel armies in Angola, Sierra Leone and the Democratic Republic of Congo to continue their brutal wars against innocent men, women and children. $^{26}$

Though the relationship between NGOs and governments had never been easy, it was the first time that such a rupture was made public. No one, least of all the NGOs, wanted conflict in the delicate process and soon afterwards the two parties were brought together.

Partnership Africa Canada and Global Witness continued to ratchet up interest in the issue by producing reports showing the various dimensions of the diamond trade: (i) on Guinea after RUF rebels and Taylor's mercenary army invaded the country in late 2000 and early 2001, striking at its rich alluvial fields in the forest regions; ${ }^{27}$ (ii) on Southern Africa, putting a question mark

26 Ibid., p. 6.

27 Lansana Gberie, Destabilizing Guinea: Diamonds, Charles Taylor and the potential for wider humanitarian catastrophe (Partnership Africa Canada, Ottawa, 2001). 
against the overall economic benefits of diamonds; ${ }^{28}$ (iii) the criminal nature of the diamond industry in Congo $;^{29}$ (iv) a study of the Kimberley Process itself, setting out a case for monitoring the rough diamond trade, ${ }^{30}$ and (v) on Sierra Leone following the UN intervention in late 1999 and the implementation of a diamond-certification scheme, showing how RUF diamond-mining interests were hampering the peace process there. ${ }^{31}$ Global Witness had earlier published a paper setting out the possibilities of identifying and certifying rough diamonds as an effective way of controlling the trade. ${ }^{32}$

A powerful impetus to the process came from a somewhat unexpected source. A major article in The Washington Post in November 2001 alleged that operatives from the Middle Eastern terrorist group, al Qaeda, had visited RUFheld diamond-mining areas several times and arranged to purchase diamonds in deals worth millions of dollars prior to the $9 / 11$ attacks in the US, implying that diamonds might have helped fund the attacks. Correspondent Douglas Farah stated in his article that the al Qaeda network 'reaped millions of dollars in the past three years from the illicit sale of diamonds mined by [RUF] rebels in Sierra Leone' and that one of the RUF's senior officials, Ibrahim Bah, of Senegalese origin, acted as 'a conduit between senior RUF commanders and the buyers from both al Qaeda and Hizbollah, a Shi'ite Muslim organization linked to Lebanese activists who have kidnapped numerous Americans, hijacked airplanes and carried out bomb attacks on US installations in Beirut'. The West African Shi'ite Lebanese community had always been suspected of having sympathies for Hizbollah, an organization that is 'active in all these countries and [is] deeply involved in many businesses across the [West African] region'. ${ }^{33}$ Interestingly, three months before $9 / 11$ and five months before the Washington Post article appeared, the names of two of those associated with the alleged relationship, Ossailly and Nassour, were placed on a travel ban announced by the United Nations Security Council. A member state had supplied these names to the Security Council. The ban also affected senior Liberian government officials and 'other individuals providing financial and military support to armed

28 Ralph Hazleton, Diamonds Forever or For Good? The economic impact of diamonds in Southern Africa (Partnership Africa Canada, Ottawa, 2002).

29 Christian Dietrich, Hard Currency: The criminalized diamond industry of the Democratic Republic of Congo and its neighbours (Partnership Africa Canada, Ottawa, 2002).

30 Smillie, The Kimberley Process.

31 Lansana Gberie, War and Peace in Sierra Leone: Diamonds, corruption and the Lebanese connection (Partnership Africa Canada, Ottawa, 2002).

32 Global Witness, Possibilities for the Identification, Certification and Control of Diamonds (London, 2000).

33 Douglas Farah, 'Al-Qaeda cash tied to diamond trade: sale of gems from Sierra Leone rebels raised millions, sources say’, Washington Post, 2 November 2001. 
rebel groups in countries neighbouring Liberia, in particular the RUF in Sierra Leone'. ${ }^{34}$ The 9/11 Commission, set up by the US government to investigate the forces behind the terrorist attacks in September 2001, would later play down any connection between the attackers and Sierra Leonean diamond interests. ${ }^{35}$ However for a time, the disclosures in The Washington Post significantly boosted the argument for tighter controls of the international diamond trade and, by implication, support for the Kimberley Process where it mattered most, namely in the US, which is by far the biggest consumer of diamond products (accounting for over half of jewellery sales worldwide).

The pressure could no longer be resisted and agreement was reached in March 2002 on the principles and most of the details of a system that would be introduced in January 2003. Provisions for the regular independent monitoring of national control mechanisms were not, however, agreed and remained an issue of serious contention for the NGOs concerned about the system's credibility and effectiveness. A final agreement was drawn up in Interlaken, Switzerland, in November 2003 requiring participating countries to ensure that all rough diamonds for export carry a Kimberley Process certificate of origin. The UN Security Council endorsed the agreement, making it international law.

The Kimberley Process is now backed by national legislation in more than 70 countries and, under it, each agrees to issue a certificate to accompany any and all rough diamonds to be exported from its territory and clearly certifies that the diamonds are 'conflict-free'. Technically, it requires each country to track the diamonds being offered for export back to the place where they were mined or to the point of import - a solution to the issue of provenance and origins and a set of standards for these internal controls must be met. All participating countries that import rough diamonds are bound by agreement not to allow any rough diamonds into their territory without an approved KP certificate. The Kimberley Process system requires the same levels of compliance in Belgium, the UK and Canada as it does in Sierra Leone, Guinea, China, Russia, Brazil and Congo, implying the same levels of technological and bureaucratic competence. This is probably its main flaw but in spite of this, however, Ian Smillie has suggested that the system has been a success:

We believe that the Kimberley Process is a success. It is a success because although there are still pockets of conflict diamonds in Côte d'Ivoire, the worst of the wars fuelled by conflict diamonds have now ended. It is also a success because it has forced a huge volume of illicit diamonds to the surface and out of the trade...

One of the reasons for the success of the KPCS, now acknowledged by everyone involved, is that it was a process, not a formula imposed from outside, and it was a

34 Lansana Gberie, War and Peace in Sierra Leone, pp. 14-22.

35 Farah has since continued to protest the truth of his claims. See Blood from Stones: The secret financial network of terror (Broadway Publishers, New York, 2004). 
process that involved governments, industry and civil society organizations like PAC. That is the good news. The KPCS has helped to consolidate the peace in several African countries... ${ }^{36}$

As further examples of this success, Smillie rightly cited the boom in diamond exports since the Kimberley System was introduced in Sierra Leone and Congo, the latter registering its best exports since the discovery of diamonds in the country about a century ago. A Diamond Certification system, anticipating the Kimberley System, was instituted in Sierra Leone in September 2000, four months after the UN Security Council passed Resolution 1306 that placed a ban on diamond exports from Sierra Leone. It was primarily meant to deny the RUF a market, and was complemented by a ban on Liberian diamond exports several months later. The certification system was created with the assistance of the Belgian Diamond High Council, which had been criticized in the PAC report for ignoring the problem of conflict diamonds. In addition to a Sierra Leonean diamond valuer, an independent valuer was also appointed. Official exports of Sierra Leonean diamonds have increased dramatically. In 1999, the country officially exported only US\$ 1.3 million worth of diamonds but in the 12 months after the certification system was introduced (i.e. between October 2000 and September 2001), legal exports jumped to US\$ 25.9 million $(210,675$ carats). Exports for the year 2001 (January to December) totalled 222,500 carats, which were valued at US\$26 million. This figure represented a monthly average export of US\$2.17 million, which was extraordinarily high compared to the years prior to the introduction of the system. This trajectory has since continued, with exports rising almost every year. Diamond exports in 2003 were worth US\$ 75 million, in 2004 the figure was US\$ 126 million; and in 2005, it was US\$ 142 million. The value of diamond exports dropped slightly in 2006 to US\$ 125 million but rose again in 2007 to US\$ 141 million.

\section{Conclusion}

Two US congressmen, Tony Hall (D-Ohio) and Frank Wolf (R-Va.), as well as Senator Patrick Leahy (D-Vt.), nominated PAC and Global Witness for the 2003 Nobel Prize. 'We are convinced that the goal of ending the scourge of conflict diamonds is achievable primarily because of the length to which Partnership Africa Canada and Global Witness have gone', the legislators wrote in their letter to the Nobel Committee of the Norwegian Parliament. They also noted that the groups:

36 Ian Smillie, 'Diamonds, Kimberley Process, and the Development Diamond Initiative' (http://www.ccafrica.ca/nrc/Ian\%20Smillie\%20Speach.pdf, November 28, 2006). 
succeeded because they have avoided polarizing campaign tactics that could have alienated the diamond industry and key governments, whose support is critical to a solution. They understood that, despite the shocking difference between the advertised image of diamonds and the often harsh reality of the trade, a boycott could result in a backlash against a product whose legitimate trade is the backbone of many economies. $^{37}$

The groups were not awarded the Nobel Prize - it went to an Iranian female activist in 2003 - but the fact that they were nominated at all for this prestigious award just three years after the campaign started is testimony to how effective and timely the 'conflict' diamonds campaign was deemed to have been.

As so often happens, the work of groups like NMJD and CENADEP that added a great deal of moral gravitas and energy to the campaign sadly went unrecognized. But because they were based at the scene of the devastation that propelled the campaign and worked tirelessly to sustain it, they were the true heroes. Too often campaigns of this nature, spearheaded by Western NGOs, appear as narcissistic indulgence, and fringe radical groups too often substitute doctrine for knowledge, and irritation with their own political and economic systems out of concern for the world's truly disadvantaged. The result can then be confusion and harm to the people they profess to represent. The lesson to be learnt from the 'conflict diamonds' campaign is that for advocacy to be taken seriously it has to be well-informed and sensitive, and should take on board the interested parties, particularly representatives of the people the advocates profess to be concerned about.

As for the countries, Sierra Leone, Angola and Congo, that inspired the 'conflict diamond' campaign, there has been significant progress in peace consolidation and infrastructural development although there are naturally still problems. The former Minister for Mineral Resources in Sierra Leone, Mohamed Swaray-Deen, appeared very pleased with efforts made by his government to better govern the diamond sector but frankly admitted that problems remained. 'Without doubt,' he said, '[the key] problems are illegal mining and smuggling, but especially smuggling. ${ }^{38}$ And illegal mining and smuggling, as the minister well knew, have been the key problems in the industry since the commercial exploitation of diamonds started in Sierra Leone in the 1930s. Importantly, government revenue from the increased diamond production remains minimal. Diamond exporters pay an export tax of $3 \%$ of the value of the goods. In addition, there is income tax, which is calculated for companies at $30 \%$ of their

37 Rob Bates, 'Conflict diamond NGOs nominated for Nobel Prize', JCK Online.com, see also (http://www.professionaljeweler.com/archives/news/2002/040402story.html, April 4, 2002).

38 Interview with Mohamed Swaray-Deen, Freetown, December 2005. 
income after other applicable deductions. But where the holder of a mining lease has yet to make a profit, or where the chargeable income is below $7 \%$ of the investment, the company pays a flat $3.5 \%$ rate of income tax. There are also the license fees paid for mining (minimal), dealing (also fairly insignificant) and exporting (at US\$ 500,000 annually, this is a significant sum). However all these taxes totalled less that US\$ 10 million in 2007. Still, the government considered it necessary to grant special tax concessions to some mining companies. For example, it granted the biggest diamond-mining venture in the country, Koidu Holdings Limited, duty-free facilities for the equipment and other mining-related goods it imports into the country, along with waivers regarding residential permits for dozens of its foreign employees. Such concessions are not limited to diamond companies. An internal government review of the mining industry estimated in 2006 that accumulated revenue losses from several concessions granted to the titanium mining company, Sierra Leone Rutile, will amount to US\$ 98 million from 2004 to 2016.

These concessions are part of the legacy of the war. Poor infrastructure and the image of a violent and unstable place have made the country unattractive to foreign investors and such concessions, the government argues, are needed to attract investments. The struggle continues in Sierra Leone. 


\title{
The Islamic Courts Union: The ebb and flow of a Somali Islamist movement
}

\author{
Jon Abbink
}

The Islamic Courts Union (ICU) in Somalia was a social-religious movement with a political programme. This internally diverse movement emerged from local Islamic courts active in Mogadishu in the late 1990s. In the absence of state authority and public security in 2004, it responded to the social needs of local people and grew into a large militia force that, by late 2006, controlled much of southern Somalia. In December 2006 a military campaign by Ethiopia, in support of the Somali Transitional Federal Government, ousted the ICU. The movement subsequently declined, split and withdrew to transform itself into a new military grouping. Its socio-religious programme waned, its violent militant agenda re-emerged and it morphed into a new nationalist movement.

This chapter considers the ICU as a social movement and questions its precedents, its social-reformist agenda and ideology, and its mobilizational procedures. The reasons for the rapid rise of the ICU in 2006 within the unstable and militarized society of southern Somalia have to be understood against the background of Muslim movements that existed in the country in earlier decades and unsuccessful attempts to establish a national government. This is marked by a mixture of political segmentation determined by the Somali clan-family system, socio-religious innovation, economic competition and local political manoeuvring in the stateless environment of southern Somalia since 1991. While local political dynamics are very important, the analysis also relates ongoing conflicts in Somali society to global geopolitics and Islamist radicalism. 


\section{Introduction: Locating the Somali case in social movement theory}

This chapter presents an interpretive case study of the Islamic Courts Union (Midowga Maxkamadaha Islaamiga in Somali) in southern Somalia, an Islamist movement that was active from c. 2004 to 2008 and had social and political aims reflecting both internal diversity (and division) and a new international positioning. A study of this movement reveals the crucial role of international contacts of all the actors on the Somali scene. This was not only evident in the persistent presence of neighbouring countries but also in the growing influence of transnational Islamic ideologies and networks, including that of Somali diaspora communities. ${ }^{1}$ These external sources provided funding, new narratives of nationalism and religious identity, and foreign-trained cohorts that impacted on socio-religious practices and ideologies in Somalia. It can be argued that seemingly local developments, like clan-militia fighting, religiously motivated battles, piracy, looting, terrorist actions and the work of Islamic charities are inextricably linked to global flows and thus highly relevant to politics and security developments in the region as a whole. ${ }^{2}$

Somalia has been in the midst of major societal transformation since 1991, not only due to the destructive civil war and the internal struggle that wrecked the country (at least its southern part), but also the transformation of customary religious life and social structures. One part of the story is the emergence of radical forms of Islam and these, although representing a minority of Somalis, seem to have become entrenched in society and redefined people's social and religious identification. The ICU, originally known as the 'Supreme Council of Islamic Courts of Somalia', was founded in $2004^{3}$ and is an intriguing example of a movement that emerged in extreme conditions of statelessness, civil war, humanitarian crisis and social disarray in southern Somalia. ${ }^{4}$ It was characterized by mobilization and recruitment on the basis of (a specific form of) Muslim

1 One in every ten Somalis lives in the diaspora, mainly in the US, Western Europe, the Middle East (Gulf States, Saudi Arabia) and neighbouring countries in the Horn.

2 Cf. Said S. Samatar, 'Unhappy masses and the challenge of political Islam in the Horn of Africa', Horn of Africa 20, (2002), pp. 1-10. See also Andre Le Sage \& Ken Menkhaus, 'The rise of Islamic charities in Somalia: An assessment of impact and agendas', Paper for the $45^{\text {th }}$ Annual International Studies Association Convention, Montreal, 17-20 March 2004.

3 In Somali: Golaha Sare ee Makhamaddaha Islaamiga ee Soomaaliya.

4 I do not discuss Somaliland here as it is a quite different story. See Seth Kaplan, 'The remarkable story of Somaliland', Journal of Democracy, 19, 3 (2008), pp. 143157, and Mark Abley, 'Successful country doesn't exist', Toronto Star, 11 September 2007. 
identity as expressed via local (clan-based) shari'a courts. In a comparative sense, the movement was challenging and perhaps puzzling to outsiders.

While social movements in Africa were present in the late-colonial and postcolonial era as nationalist insurgent groups, neo-traditional movements or in the more classic form of trade unions and civic organizations, variations based on a predominantly religious agenda have been rare ${ }^{5}$ and little studied. Compared to other parts of the world, similar ideas on recruitment, ideology and socio-political agendas around grievances or political aims in Africa were always present but cultural commitments and value orientations of movements as well as their strategies differed markedly. In Africa, movements with an allegedly religious identity basis are growing in importance, often as their adherents see the classical social movements, such as trade unions, parties and civic associations, as ineffective or conservative.

This plethora of new socio-political movements in Africa has broken the framework of social movement paradigms that we know from the mainstream literature and that have been developed on the basis of mainly European and American cases. ${ }^{6}$ New combinations of social, neo-ethnic, religious and criminal elements of collective self-definition have emerged and are taking shape in semi-collective, often opportunistic, alliances resonating with recent theories about 'low intensity conflicts' and 'new wars'. When studying these movements in Africa, the challenge is to explain their emergence, mobilization potential and evolving agendas as they unfold.

In much of the literature one comes across a conception of social movements as primarily grievance-based and democratically oriented collectivities of people or social groups, usually neglected by the state, that are striving for the public good. This idea of legitimate grievances and of democratic aspirations cannot, however, be part of the definition of social movements, as it would prejudge their nature. As the Somali case will illustrate, some movements are political groups aimed at imposing their agenda and exercising power in a coer-

5 The Kenyan Mungiki movement, which emerged in the 1990s, is another example of a complex, 'neo-ethnic' social movement based on a mixture of religious and sociopolitical elements. However subject to brutal government repression, it lost its leadership and has transformed into a movement where criminal and violent activities have undermined its socio-political agenda. See for a recent study, Awinda Atieno, 'Mungiki, 'Neo-Mau Mau' and the prospects for democracy in Kenya', Review of African Political Economy, 34, 13, 2007, pp. 526-531.

6 South Africa is the only country in Africa where social movements have occurred in significant measure and been studied in recent years. See for example, Richard Ballard, Adam Habib, Imraan Valodia \& Elke Zuern, 'Globalization, marginalization and contemporary social movements in South Africa', African Affairs, 104, 417 (2005), pp. 615-634. 
cive fashion, with social aims or issues as secondary. Others want to impose an exclusivist programme on society, merging the social and the political in a comprehensive religious cloak. The definition of social movements must, therefore, be more nominal and open, focusing on mobilization and public action towards an aim at variance with the state, other movements or forces in society. In this chapter I use the general definition offered by Olzak ${ }^{7}$ and define a social movement in its broader sense as a purposive collective movement voicing demands for fundamental change in society, mobilizing around one or more public causes and following a strategy of change. A broad variety of issues can be addressed by a movement, ranging from state discrimination, neglect, socioeconomic and political marginalization to perceived value differences.

In the case of the Islamic Courts Union (ICU), questions can be asked about whether it is, or was, a social movement and, if so, how it differs from those known from the literature. It was certainly a movement of people acting collectively with a social and political programme, claiming public causes and dressing their actions in a religious garb, sincere or otherwise. They addressed social problems that emerged in the vacuum of post-1991 Somalia and the collapse of its central state. However, according to sociologist Tilly, ${ }^{8}$ the ICU would probably not qualify as a social movement because in his strict definition, based on Western European experience, it seems to lack the specific complex of defining elements (campaigns against target authorities; action repertoires, public displays). ${ }^{9}$ However I claim that the ICU and its predecessors should be tested against historical examples and in this case it could be said to be a collective action movement adapted to the quite specific, stateless environment of a clandivided society. It is of prime importance here to look at the emergence and actions of movement elites.

A challenge when studying African cases is how to address cultural frameworks $^{10}$ and the - often disruptive - religious factor in social movement re-

7 See Susan Olzak, 'Ethnic and nationalist social movements', in: David A. Snow, Sarah A. Soule \& Hanspeter Kriesi (eds), The Blackwell Companion to Social Movements (Blackwell/Malden, Oxford/Carlton, 2004, p. 666.

8 Charles Tilly, Social Movements, 1768-2004 (Paradigm Publishers, London/Boulder, 2004), pp. 3-4, 7.

9 His definition of a social movement in his essay 'From interactions to outcomes in social movements' (in: M. Giugni et al. (eds), How Social Movements Matter, p. 257 ) is equally restrictive and although perhaps applicable to Europe may not be so for many other societies.

10 See Stephen Hart, 'The cultural dimension of social movements: A theoretical reassessment and literature review', Sociology of Religion, 57, 1 (1996), pp. 87-100. 
search. ${ }^{11}$ Cultural-religious factors are quite different and probably more important for social movements in Africa than elsewhere. A movement that observers may see as religious or social is often at the same time inherently political (or vice versa) because the domains are fused and drawn upon opportunistically. This is certainly true in the Somali case. It could be contended that religion was the 'master frame" 12 of the ICU for their view of Somali society and their course of action but it should not be forgotten that Somali clan-group thinking (i.e. social organization based on the segmentary patrilineal principle, or tol in Somali) interacted with this. I refrain here from fully answering the question about whether the ICU was really a social movement and instead aim to explain the movement with the help of insights from social movement theory (cf. van Stekelenburg's chapter in this volume). Within the various theoretical traditions of social movement research, a 'political process approach' ${ }^{13}$ seems promising in explaining the ICU, although a more comprehensive social-constructivist point of view would also be helpful in view of the strong identity aspects in the movement (Islamist ideology) that gave it additional mobilizing capacity.

The Somali civil conflict is fully connected to transnational global politics and can no longer be explained solely as a part of the country's socio-political crisis and its divisive clan system: the ICU was not only responding to a domestic agenda of social grievances. Somali actors have placed themselves in alliance with transnational flows of funds, organizational forms and ideologies. Indeed both the current Somali Transitional Federal Government (TFG) and the ICU were decisively influenced by foreign connections, with the ICU opting exclusively for those in the Muslim world.

\section{The Somali arena today:}

\section{Fragmentation, insecurity, persistent violence}

Somalia has been bad headline news in recent years: political disorder, persistent civil strife, ${ }^{14}$ terrorist actions, military abuse, a catastrophic humanitarian

11 Cf. Christian Smith, 'Correcting a curious neglect, or bringing religion back in', in: Christian Smith (ed.), Disruptive Religion. The Force of Faith in Social Movement Activism (Routledge, London/New York, 1996), pp. 1-25. The role of the symboliccultural dimension in social movement is treated well in: Donatella della Porta \& Marco Diani, Social Movements: an Introduction (Blackwell/Malden, Oxford/Carlton, $2^{\text {nd }}$ edition, 2006), but they do not touch on the role of religious elements.

12 Cf. Della Porta \& Diani, Social Movements, p. 79.

13 Ibid., pp. 16-18.

14 See Hussein Adam, From Tyranny to Anarchy: The Somali experience (Red Sea Press, Trenton, NJ/Asmara, 2008). 
situation for $30-40 \%$ of the population, ${ }^{15}$ extortion, the kidnapping and killing of aid workers, and a piracy-infested coastline unsafe for international shipping. ${ }^{16}$ While there are huge numbers of studies and reports on Somali and a good general understanding of the underlying problems of state failure, social (dis-)organization and economic life in the literature, the country's politics are exceedingly complex.

Although two parts of the former state of Somalia - self-declared independent Somaliland and the less-successful but fairly stable Puntland ${ }^{17}$ - are enjoying relative calm, southern Somalia and notably the capital Mogadishu and its environs have remained locked in insecurity and political fragmentation, first under warlords and clan militias (1991-2005) and since 2006 in devastating violence between parts of the ICU and TFG troops supported by Ethiopian forces that have been in the country since December that year. At least 10,000 people, about $60 \%$ of them civilians, have been killed since the December 2006 war, many more have been wounded and hundreds of thousands have become internally displaced persons (IDPs).

Since the collapse of the central state in Somalia, the various insurgent movements have not succeeded in forging a new state and have plunged the country into civil war and a predatory economy. The history of the ensuing civil conflict and war is too complex to cover here. ${ }^{18}$ However, communal conflicts and population movements have created deep antagonisms between various clan and sub-clan groups, opportunistic alliances for economic gain and massive victimization of minorities and non-clan Somalis. ${ }^{19}$ For example, in the wake of the expansion of the then-powerful USC militia of General Mohammed Farah 'Aydeed', Mogadishu was flooded with many Hawiye clan people (notably the Habr-Gedir sub-clans of Murosade, Suleimaan and 'Ayr) who replaced or

15 See the alarming report by the Food Security \& Nutrition Analysis Unit Somalia, Quarterly Brief (Nairobi, issued 12 September 2008. Online at: www.fsausomali.org, accessed on 1 September 2008.

16 Piracy along the Somali coast was already being recorded in 1998. A major action was the capture on 4 January 1999 of the MV Sea Johana by units of the radical Islamist Al Ittihad Al Islami group. See S. Coffen-Snout, 'Pirates, warlords and rogue fishing vessels in Somalia's unruly seas'.

(www.chebucto.ns.ca/ ar120/somalia.html, June 1, 1999); R. Middleton, Piracy in Somalia. London: Chatham House, Briefing Paper, October 2008.

17 Their armed border conflict in 2007, however, shows that one cannot speak of stability here either.

18 See Hussein Adam, From Tyranny to Anarchy, p. 81f.

19 The popular perception of Somalia as a homogeneous country is not true. There are significant minorities and groups falling outside the clan system (with its five major clan-families of Dir, Darod, Hawiye, Rahanweyn and Isaaq). 
chased out non-Hawiye inhabitants, a lot of whom were from the Darod clan. Similar displacement happened in the countryside, for example in the Rahanweyn agricultural areas. The many unresolved conflicts of interest and illegal appropriations constitute an important sub-text surrounding the perennial conflicts in Somalia today.

Heavily hit by repression and war in the final years of the rule of President Mohammed Siyad Barre who was in power from 1969-1991, Somaliland declared independence in 1991 and disassociated itself from the idea of a panSomali state. Puntland followed in 1998 by declaring autonomy but not independence. Southern Somalia has remained divided and stateless. In spite of the absence of a central state since 1991, not all has been chaos and mayhem. While Somali society fell back on clan territories, the rule of clan elders, local NGO activity and Islamic organizations, local self-governing units emerged and to a large extent stabilized the rural areas. In the cities, predatory militias and warlords were dominant and insecurity, especially in the large towns like Mogadishu, remained rampant. But even there, efforts at community regulation emerged, although largely within same-clan units.

Paradoxically, the Somali economy has had a mixed record over the past years. While poverty is deep-rooted, state services non-existent and the agropastoral sector in serious crisis, there is a free, mostly unregulated economy with a booming trade and telecom sector $^{20}$ as well as a transnational criminal/racketeering sector that brings in money. And in the last two years millions of dollars have also come from piracy off the coast. The qualified economic success of the entrepreneurial sector has allowed Somali businessmen and movements to tune in to global economic networks and forge new politicalideological connections. Not only are hundreds of millions of dollars being transferred from the Somali diaspora ${ }^{21}$ each year (flowing to all parties in the conflict but especially to the Islamic Courts movement) but religious funding and arms flows from Middle Eastern countries and Eritrea are also relatively easily arranged. ${ }^{22}$ The informal, trust-based and highly effective hawala money

20 See Bob Feldman, 'Somalia: amidst the rubble, a vibrant telecommunications infrastructure', Review of African Political Economy, 113 (2007), pp. 565-572.

21 A recent World Bank report mentions the very high amount of $\$ 1$ bn annually, or $71.4 \%$ of GNP. See Samuel M. Maimbo (ed.), Remittances and Economic Development in Somalia. An overview (World Bank, Washington, DC, 2006), p. 5. The UNDP in 2007 estimated half this sum.

22 Well-documented in the reports of the UN Monitoring Group on Somalia. See for instance the amazingly detailed report of November 2006

(www.fas.org/asmp/resources/govern/109th/S2006913.pdf, November 21, 2006). Eritrea's support was also admitted by the former ICU leader back in 2006, see 
transfer systems have undoubtedly contributed to the funding of militants and terrorists ${ }^{23}$ in Somalia as well, ${ }^{24}$ and economic interests are an important driver of the conflict. ${ }^{25}$

Over the past eighteen years, various efforts have been made to rebuild a nation state, often at the instigation of outsiders such as the UN. These efforts were perhaps premature and unduly top-down because they sidetracked the then-ongoing 'building blocks' approach to Somali political reconstitution, which was widely seen as the best way forward. ${ }^{26}$ The external state-building effort gave rise to the Transitional National Government (TNG) in 2000 which was constituted at a conference in Arta, Djibouti. After its collapse, it became a somewhat more representative Transitional Federal Government in 2004, with a five-year mandate. It was based on difficult negotiations in Mbagathi, Kenya, offering a compromise between clan-families on representation and the division of power. The TFG, led by the former Puntland president and veteran Somali politician/warlord Colonel Abdullahi Yusuf Ahmed (of the Omar Mahmud/Majerteen/Harti/Darod clan), was recognition, to an extent, that a future Somalia should be significantly federal in structure. ${ }^{27}$ However it soon ran into trouble and was not able to relocate to Mogadishu due to the insecurity and lack of authority there. One problem was that Abdullahi Yusuf, although experienced and strong, was controversial due to his authoritarian style and his close relationship with Ethiopia. He was not a conciliatory president.

The other forces providing alternative sources of survival and social order were Islamic movements, notably the Islamic Courts in Mogadishu. Before they appeared on the scene as an organized movement in early 2006, they had been building a constituency based on a range of service-oriented Islamic associa-

'Somalia: Islamists refuse talks, acknowledge Eritrea', Reuters news message, 26 July 2006.

23 Terrorism is defined in this chapter as unpredictable violent action against non-combatants and innocent people with the intent to kill and destroy, create existential fear and subvert the public order, usually with a stated political aim.

24 Robert Feldman, 'Fund transfers-African terrorists blend old and new: hawala and satellite telecommunications', Small Wars and Insurgencies, 17, 3 (2006), pp. 356366.

25 Cf. Sabine Grosse-Kettler, External Actors in Stateless Somalia. A war economy and it promoters (Bonn International Center for Conversion, Bonn, BICC paper 39, 2004).

26 Cf. Matt Bryden, 'No quick fixes: coming to terms with terrorism, Islam and statelessness in Somalia', Journal of Conflict Studies, 23, 2 (2003), pp. 24-56.

27 Incidentally, its Charter also recognized Islam as the state religion and shari' $a$ as an important source of national law. 
tions and charities that had existed in the country for decades (founded on the Muslim duty of zakāt).

\section{Earlier Muslim movements in Somalia: A religious infrastructure}

Somalia has been a Muslim country since at least the thirteenth century and has known a wide range of (mostly Sufi) ${ }^{28}$ Islamic associations with their important mystical orders and holy men as mediators and models of piety. Virtually all Somalis are nominally members of a Sufi order, the most important being the Qadiriyya, the Idrisiyya and the Salihiyya. Women are also members. These orders are usually non-political but can be used as organizational vehicles for resistance when faced with external enemies, as in the rebellion by Mohammed Abdulleh Hassan against colonial rule in 1900-1920. While Islam is a core element in the identity of Somalis, they also recognize clan affiliation and customary or contract law (heer) as defining elements in their heritage. The rise of the ICU was due to the long, organized presence of Islam in Somalia. A number of the organizations are mainstream Muslim associations of a social, educational and/or religious nature, and some are militant, with a programme of coercive or violent expansion and international connections and ambitions. Among the indigenous Somali organizations the most important are:

- Harakat al Islah (Movement for Revival) This movement was founded in 1978 with the aim of reconciling Islam and the modern world. It did not openly operate under the Siyad Barre regime but was more of a network of educated urban professionals and students. It ran social, humanitarian and educational activities and was said to opt for 'Islamic democracy'. Their programme rejects Salafism and the use of force, and the organization is known to be open to contact with foreign organizations, also those in the West. $^{29}$

- Ahl As-Sunna wal Jama'a (People of the Sunna and the Community) This was set up in 1991 and has its basis in Somali Sufism, to which it claims to provide national leadership. It is a movement with branches elsewhere, is opposed to militant/reformist Islam and claims to represent traditional, main-

28 See Lee V. Cassanelli, The Shaping of Somali Society: Reconstructing the history of a pastoral people, 1600-1900 (University of Pennsylvania Press, Philadelphia, 1982); Ioan M. Lewis, A Modern History of Somalia: Nation and state in the Horn of Africa (Westview Press, Boulder, CO, 1988).

29 International Crisis Group, Somalia's Islamists (ICG, Brussels, 2005, Africa Report no. 100), p. 14. A longer study of Al Islah is contained in Andre Le Sage, Somalia and the War on Terrorism. Political Islamic movements and US counter-terrorism efforts (Cambridge University Press, Cambridge, 2004, unpublished $\mathrm{PhD}$ thesis), pp. 159-184. 
stream Muslims in Somalia. ${ }^{30}$ They specifically tried to counter SalafistWahhabist versions of Islam, and thus inevitably became involved in politics. The group played a role in the peace negotiations in Mbagathi (Kenya) that led to the TFG in 2004. Its efforts to mediate between politics, radical Islam and Somali Muslim traditions have often placed it in a difficult position. In late 2008 it started to form militias to counter the al Shabaab insurgents.

- Al Ittihad al Islami (Islamic Unity) This movement was founded in 1984, bringing together the two earlier Islamic groups of al Takfir al Wahda (also called Wahda al-Shabaab al-Islaami) and the Somali branch of the Salafi Ikhwan al Muslimiin (Muslim Brotherhood) that were both formed in the 1960s but suppressed by former President Mohamed Siyad Barre. Al Ittihad al Islami was first led by the Somaliland sheikh Ali Warsame, a Saudieducated Wahhabist cleric still active today. ${ }^{31}$ While al Ittihad had a social component, it was primarily a political Islamist movement of militants, aiming to islamize Somali society, install an Islamic state in Somalia and agitate among Somali Muslims in Ethiopia. It became embroiled in violent disputes and battles with a variety of opponents in and outside Somalia and had a record of imposing its Islamist agenda (see below).

- There are also Islamic missionary groups like the Jama'at al-Tabligh, the Ansar as-Sunna ${ }^{32}$ and an association of Somali 'ulemas called Majma' 'Ulimadda Islaamka ee Soomaaliya. While these have no social or charitable programmes, their ideological influence is significant and impacts on traditional forms of Somali Islam.

These various groups are best considered as religious rather than social movements with a clear programme and agenda of social protest. They were primarily organizations bent on fostering Somalia's Islamic identity and furthering the interests of Somalis in a state where political opposition was impossible. The exception is perhaps Al Ittihad al Islami. Since the early 1980s it has been a constant presence in Somalia in various forms, both as a social movement with its own services and propagandist-educational activities and as a religiously motivated militant movement. ${ }^{33}$ It formed various opportunistic alliances with some of the Somali Muslim civil-society associations outlined above. It has a record of terrorist attacks within Ethiopia that were part of its attempt to stir up unrest among Ethiopian Somali Muslims. Its bases in the

\footnotetext{
Matt Bryden, 'No quick fixes', p. 34.

He is a member of the Somaliland Habr-Ja'elo/Isaaq clan.

International Crisis Group, Somalia's Islamists, pp. 16-18.

33 For a detailed account by an Ethiopian academic, see Medhane Tadesse, Al-Ittihad: Political Islam and Black Economy in Somalia (Mega Printing, Addis Ababa, 2002).
} 
Gedo region just across the Ethiopian border provoked a campaign by the Ethiopians in 1996-1997 that dislodged them and killed many of their leaders.

After this defeat, Al Ittihad Al Islami abandoned its international ambitions and developed a domestic agenda aimed at creating a semi-legal social network within Somali society, which was reminiscent of the National Islamic Front in Sudan before the 1989 coup. Though never renouncing its international links, it went into social projects, education and organizational activities to win a grassroots constituency and gain adherence for its views on Islam and society among the general population. ${ }^{34}$ It built up a network of sympathetic clerics, most of whom had trained in other Muslim countries and were asserting their views of 'proper Islam' as opposed to Somali variations, i.e. a rejection of saints and Sufism. Al Ittihad Al Islami became active not only in southern Somalia but also in Somaliland and Puntland, trying to gain a public presence by calling for stricter Islamic morality in the public sphere in the two countries. The assassination of various foreign humanitarian workers, teachers and civil-society figures were also attributed to the movement. Their actions were controversial and generated unrest, ${ }^{35}$ but they had a following. After the TNG's formation in 2000 they were close to the new government ${ }^{36}$ and are still around today although they have lost some of their momentum in the wider society.

\section{Filling the state vacuum: From Al Ittihad al Islami to the ICU}

The Islamic Courts Union, later called the Supreme Islamic Courts Council, emerged as an organized force in 2004 and, with a military wing, in early 2006. This marked their arrival on the political scene. The ICU's rapid rise and decline in the unstable and militarized society of southern Somalia are intriguing. The organization was led by several former Al Ittihad Al Islami figures, most importantly by former army colonel and al Ittihad leader Hassan Dahir 'Aweys', (of the Ayanle/'Ayr/Haber-Gidir/Hawiye clan) who became chairman of its Shura or Advisory Council. Sheikh Sharif Sheikh Ahmed (of the Agonyare/Abgal/Hawiye clan), a former teacher and an Ahlu as Sunna wal Jama'a member, has been its Executive Council head since 2004 and has always been presented as a moderate leader. When it was set up, the ICU was internally

34 Cf. Andre Le Sage, 'Prospects for Al Itihad and Islamist radicalism in Somalia,' Review of African Political Economy, 28, 89 (2001), p. 475.

35 See Somali journalist Bashir Goth's interesting article, 'Thwarting the menace of Islamism in the Horn of Africa', on the Somaliland website (www.awdalnews.com/wmview.php?ArtID=4146, November 8, 2004).

36 According to Medhane Tadesse, (Al Ittihad, pp. 113 and 126), the TNG was dominated by al Ittihad people. 
diverse and had radicals, (ex-)terrorists, Salafists and mainstream Muslims within its ranks. Islamist clerics like Sheikh Fuad Mohamed Qalaf were its ideologues. ${ }^{37}$ As stated above, the ICU emerged from a number of shari'a courts in the Mogadishu region and its predominant clan base was Hawiye/Habr-Gidir. In the course of late 2005-2006 it evolved into a movement with a large militia force with its own 'technicals' (pick-up trucks with machine guns mounted in the back) and other weaponry. It acted as another armed force, rejecting the TFG and planning its military downfall. The ICU could thus in many respects be compared with the warlord/clan militia forces, pursuing a similar armed struggle to power but in this case in the name of Islam.

Their significance can be explained by the practical concerns of ordinary Somalis and business people with improving public safety and eliminating the predatory warlords and loose militias. While many ordinary people had cooperated with and profited from warlord or militia activities (if they were of the same clan), the general perception was that the warlords and militias had overplayed their hand by holding with impunity the city of Mogadishu in a stranglehold of violence, abuse and extortion. The Islamic Courts responded to an increasingly felt need among Somalis for public order and an end to the wholesale insecurity that had become a serious impediment for business and progress. To consider the ICU from its start as a front for radical Islam is, therefore, a mistake.

New modes of national governance and judicial structures in the clanordered anarchy of Somalia had constantly been sought since 1991, with at least a dozen attempts to constitute a national government. It should not be forgotten though that in the meanwhile many local solutions to the problems of instability and state absence were also developed. Indeed before the formation of both the TNG in 2000 and the TFG in 2004, Somalia had already gone a long way to creating working local/regional units based on a combination of clan-elder rule, deep-rooted customary law (heer), Islamic law and NGO activity (mainly those of Somali women). This was the so-called 'building blocks' approach. ${ }^{38}$ However, the hotspot of Mogadishu remained violent. In the socio-political and legal vacuum of the city - and several other towns like Beledweyn and Kismayo the Islamic Courts emerged as the only force with authority, providing a pragmatic regulation of disputes, combating street crime and protecting business deals. In the urban context, clan elders and customary law had lost much of their relevance as sources of judicial regulation.

37 Remarkably, he had worked in Sweden for 12 year as the imam of a Stockholm (Rinkeby) mosque before returning to Somalia in 2004.

38 Cf. Patrick Gilkes, 'Briefing: Somalia', African Affairs, 98, 1999, p. 577. 
The courts were originally regular shari'a courts, like those found all over the Muslim world. The first phase of the courts' movement began just after the collapse of the state in 1991 when the Islamic group Al Ansar as-Sunna set up the first court in the Madina neighbourhood of northern Mogadishu, and was active within the Abgal sub-clan of Hawiye. Others followed, in Mogadishu and elsewhere, like the Hawadle clan court in Beledweyn, but this first wave of courts declined in the late 1990s due in large part to intra-Abgal clan competition, radical elements trying to take them over and a growing resentment to harsh shari'a punishments like the amputation of limbs. After a few years, a second wave of courts emerged in Mogadishu and Merca, and in 2000 they formed a shari'a Implementation Council, on which Hassan Dahir 'Aweys' reappeared. He was chairman of the Ifka Halane court (predominantly of the 'Ayr sub-clan), which was founded in 1998 and was known to be a hard-line court.

At the Arta peace conference in Djibouti in 2000, the Islamic Courts were represented as a movement. ${ }^{39}$ In the next few years, eleven courts appeared in Mogadishu: ten from Hawiye sub-clans and one from the Jareer-Bantu people. They tried to transcend clan interests and appeal to wider principles of conflict regulation and justice 'on the basis of Islam', and partly succeeded. Their spokesmen often drew explicit parallels with the time of the Prophet Mohammed who, when establishing Islam as the dominant religion, had agitated against Arab clan divisions. The courts forged an alliance, thus increasing their relevance as an incipient social movement, and the ICU found support among a growing number of local businessmen, some of whom became the movement's core financiers. Members of the individual courts were Muslim clerics but also business people and clan elders and they became popular by creating order, cleaning up the streets and finding solutions to the problems of crime and insecurity caused by the warlords and criminal bands. That an Islamic message was part of the deal was accepted for the time being. As Ken Menkhaus noted, 'Though many Somalis were deeply uneasy with the radical and reckless direction the ICU leadership gradually took, they were willing to tolerate almost anything in return for public safety'. ${ }^{40}$ This was realized by mediation in intraclan dispute resolution, a furthering of inter-clan cooperation, the imposition of fines and compensation payments, and the enforcement of judgements and agreements, for which militia were used. Most of the courts, interestingly, took

39 See 'Interview with Islamic Courts chairman Hassan Sheikh Mohamed Abdi', in the In-Depth IRIN report 'Somali National Peace Conference' (www.irinnews.org/InDepthMain.aspx?InDepthId=54\&ReportId=72096\& country=y es, July 2000).

40 Ken Menkhaus, 'Who broke Mogadishu?', The Guardian, 17 January 2007. 
care not to go against the principles of Somali customary law (heer), certainly not before their takeover of power in Mogadishu. They were usually supported in local communities and received voluntary financial contributions from both businessmen and the general population.

The ICU was formed in 2004 and sought an extension of the authority of the courts that morphed into a social movement with a more structured leadership and wider socio-political aims derived, in part, from Islamic charities and movements that existed before the Courts' movement emerged. They tried to bring the entire country under their influence, stabilize it and form a new structure of (religious) authority to replace the state.

This success, having responded to social needs and built up momentum, attracted Islamist militants, activists and former Al Ittihad leaders who saw in the Islamic identity and popular acceptance of the courts a way to move forward with their agenda of islamization, denying the relevance of Somali customary law and other sources of legislation. In addition, they saw the chance to subvert their main opponent, namely the TFG and its strongly anti-al Ittihad president Abdullahi Yusuf (who had prevented an Al Ittihad coup in Puntland in 1992). ${ }^{41}$ At this juncture and fuelled by former Al Ittihad members, the expansion of the courts, by taking on militias as their executive arm and enforcing their rule, went beyond its regular jurisdiction and brought them to the threshold of politics. It was a crucial moment in recent Somali history when a potentially positive social movement turned into a political force, but one jeopardizing the chances of its own success by embarking on expansion using violent means. This was also a development that most Somalis did not appear to approve of, although it was indicative of the fundamental changes in Somali society and Somali Islam.

\section{ICU rule: June-December 2006}

The ICU was a heterogeneous alliance of Islamic groups, Islamic courts and radical-Islamists in opposition to the TFG. As noted, it had its roots in the earlier Al Ittihad al Islami that was formed in $1984,{ }^{42}$ which explains why parts of the ICU were already geared to a radical Islamist agenda. The ICU took over power in Mogadishu in June 2006 after it chased out a coalition of clan-militia leaders and warlords from Mogadishu. These warlords had divided southern Somalia and Mogadishu into personal business fiefs and were responsible for the road blocks, arbitrary rules, the extortions and most of the violence against

41 For a good survey, see International Crisis Group, Somalia's Islamists, pp. 5-6.

42 See Matt Bryden, 'No quick fixes', p. 28, and Sunguta West, 'Somalia's ICU and its roots in al-Ittihad al-Islami', Terrorism Monitor, 4, 15, 27 July 2006. 
civilians. Some of them had loosely declared their allegiance to the TFG but did not submit to its authority. ${ }^{43}$ In a notoriously ill-judged policy, the US government, concerned about terrorist al Qa'eda operatives in Somalia, had been supporting an alliance of such warlords with logistics and funds since early $2006 .{ }^{44}$ Surrealistically called the Alliance for the Restoration of Peace and CounterTerrorism (ARPCT), the US believed them to be a bulwark against terrorist elements within the ICU. ${ }^{45}$

After the ICU defeated the ARPCT in June 2006, it reigned in Mogadishu for six months and extended its rule to most of southern Somalia, bringing increased security and public order. Road blocks were removed, garbage was collected and many criminal gangs were taken off the streets. Its ideology had, however, become clearer in its leaders' pronouncements ${ }^{46}$ and was unambiguous. As the Islamic Courts' first vice-chairperson Abdelrahman M. Jinikow said in September 2006: 'We will only approve a constitution based on theology because an Islamic constitution is the only one that serves all of us justly'. He added that the TFG government's current 'man-written constitution has nothing to do with Islam' and that '[a] secular constitution, whether it is democratic or any other, is never fair and right, and Muslims have only one constitution which is entirely based on Allah's Koran that will avail all Muslims in the world now and Hereafter'. ${ }^{47}$ They tried to impose strict shari'a-based rule, which soon evoked resentment. The idea that the ICU was a benign and fully accepted regime has to be dismissed in view of the violence they inflicted ${ }^{48}$ and the un-

43 Many warlords, notably in the countryside and the smaller cities, remained outside the ARPCT. An example is the notorious Yusuf Mohammed Siyad 'Indha'adde (Hawiye, 'Ayr sub-clan), who had established himself in Merca and appropriated plantations and other property there. In 2006 he joined the ICU and became one of its most uncompromising spokesmen.

44 See 'U.S. secretly backing warlords in Somalia', Washington Post, 17 May 2006.

45 See also Matt Bryden, 'Washington's self-defeating Somalia policy', CSIS, Africa Policy Forum comment (http://forums.csis.org/africa/?p=18, December 6, 2006).

46 See for example an interview with Hassan Dahir 'Aweys' in Rod Norland, 'Heroes, terrorists and Osama', Newsweek, 22 July 2006, and also 'Militia leader calls for Islamic rule in Somalia' (AP news message, 13 October 2005). An interesting confidential document on their programme is a letter by Hassan Dahir 'Aweys' (http://wikileaks.org/wiki/Category:series/Inside_Somalia_and the_Union_of_Islam ic- Courts , November 9, 2005).

47 See 'Somalia: we accept no constitution other than Islamic - Islamic courts', Shabelle News Media message (www.benadir-watch.com/2006\%20News/0906_Islamic_courts.pdf, September 6, 2006).

48 A few examples: after they took over they had women without veils publicly lashed, they introduced shari'a law punishments literally, like amputations and stonings, 
popular measures they took. ${ }^{49}$ The independent media and women's NGOs were threatened as well and is evidence of how the ICU quickly marginalized the role of civil society.

With inflammatory rhetoric, the ICU set out its wider political ambitions in the region: 'uniting all Somalis in the Horn of Africa, ${ }^{50}$ '[the] installation of a shari'a-based Islamic state' and 'jihad against Ethiopia'. ${ }^{51}$ This reflected the ICU's immaturity as a movement.

An important result of the ICU victory was its takeover and appropriation of many of Somalia's economic activities. Some of the ICU's major financial backers were indeed important businessmen, like Ahmed Nur Jim'ale, former chairman of the telecom/remittance company Al Barakat, and trader Abukar Omar Adani who had his own militia. ${ }^{52}$ In fact, the start of the ICU offensive in 2006 may have been sparked by a conflict over the control of the profitable El Ma'an port (30 km north of Mogadishu) between Adani, calling in ICU militias, and militia leader Bashir Raghe. ${ }^{53}$ In addition, in late 2006 many of the thousands of former warlord militia members of the defeated ARPCT, the moryaan (marauding armed youths), turned up in ICU militias, perhaps less out of religious conviction than because of perceived economic prospects (a fixed salary of US\$ 70 to US\$ 150 per month).

they shot and killed people watching television, and in one incident they dragged wounded, loyal TFG supporters in Bu'ale from their hospital beds and killed them (cf. United Nations Joint Logistics Center, NGO-SPAS, 'Somalia - security update, report no. 44/06', 26 Oct. - 01 Nov. 2006). The Al-Shabaab militia, the main perpetrator, had already built up a record of abuse and violence in previous years, including targeted abductions, the assassination of aid workers and civil-society activists, and other grave desecrations. This fits with the record of terrorist actions of its predecessor Al-Ittihad al-Islami.

49 This led Somali researcher Said S. Samatar to note that if Somalia were to be left to sort itself out alone, the movement would be absorbed by clan-based politics and lose its prominence and radicalism. See his 'Why Somalia is no territory for Islamic terrorists'

(http://wardheernews.com/Articles_06/August_06/15_somalia_no_territory_for_terr orists_samatar.html, August 16, 2006).

50 For example, they also threatened Somaliland and made pronouncements against its budding democracy and relative stability.

51 For example, 'Somali militia declares jihad against Ethiopia', International Herald Tribune, 9 October 2006, and 'Somali hardliner calls for foreign jihadists', The Observer, 24 December 2006.

52 See: Report of the Monitoring Group on Somalia pursuant to Security Council resolution 1676 (2006), UN document S/2006/913, p. 10.

53 Both men were members of the Warsangeli/Abgal/Hawiye sub-clan. 
In the six months up to December 2006 there were half-hearted negotiations between the ICU and the TFG on power-sharing. When in December that year the ICU threatened to conquer Baidoa, the town where the weak but internationally recognized TFG of Somalia was entrenched, the Ethiopians, who were fearful of an Islamist government on their doorstep and committed to the IGAD peace process ${ }^{54}$ moved in 'at the request of the TFG' with thousands of soldiers and defended the TFG. A quick push towards Mogadishu ousted the ICU from the capital, forced them to disperse and go back to their (mainly Hawiye) clan territories where they were reproached by clan elders for having provoked the Ethiopian intervention with their armed campaigns.

\section{International dimensions: Impact of the Ethiopian intervention}

Before 2006 Ethiopia had followed developments in Somalia with an apprehensive eye, wary of the ICU's Islamist element. Ethiopia sees itself as having legitimate security concerns regarding Somalia in view of two previous wars and a possible radicalization of its own Muslim population (ca. $38 \%$ of the total). While its role has not always been positive, Ethiopia appears to be working for a stable and manageable Somalia. Its relations with Somaliland and Puntland are good but the South is a problem. The Addis Ababa government also fears ethno-nationalist sentiments among the Ogaden Somalis, some of whom had links with Al Ittihad al Islami in the 1990s and have been waging an armed rebellion against the Ethiopian administration in Somali Region 5, which intensified in 2007 with a terrorist attack by the ONLF (Ogaden National Liberation Front founded in 1984) on an oil exploration site in eastern Ethiopia in which 65 people were killed.

Ethiopia has consistently supported the Somali Salvation Democratic Front (SSDF) of the current TFG president Abdullahi Yusuf and various non-Islamist groups among the Digil-Rahanweyn in the Bay-Bakool regions bordering Ethiopia. It rejected the previous transitional national government that emerged from the 2000 'Arta Process' in Djibouti and gave rise to an even weaker government with less legitimacy than the current TFG.

Within the IGAD framework, Ethiopia supported Abdullahi Yusuf's bid for the presidency in 2004 and made itself 'guarantor' for the newly constituted TFG. The seat of this government in Baidoa was protected in part by Ethiopian troops, as was the case when the ICU forces, having refused meaningful nego-

54 This process of negotiations under the auspices of the IGAD (International Governmental Authority on Development, an organization of states in the region) in Kenya in 2002-2004 involving Somalia's various clan factions led to the Mbagathi agreement to establish the TFG in October 2004. 
tiations with the TFG, advanced on Baidoa in December 2006 with the intention of conquering it. Their ultimatum to the TFG and the Ethiopians, made in the same reckless manner as most of their other actions, was met with a rapid offensive by the TFG and the Ethiopians that militarily cleared out the ICU from Mogadishu, destroyed much of their militia and infrastructure, and allowed the TFG (but not Parliament) to enter Mogadishu.

Ethiopia was aware of the (still ongoing) support that Eritrea was providing to those opposed to the TFG and their own forces, including al Shabaab and other militant groups. The UN Somalia Monitoring Group reports of 2006 and 2007 documented the arms flows and other foreign assistance in remarkable detail. ${ }^{55}$ A proxy war is thus still being fought out, preventing easy domestic resolution of the conflict.

The impact of the Ethiopian intervention on the domestic scene since early 2007 has been substantial. It has led to the ICU dividing into at least three sections, reflecting the various social bases and ideological currents of Somali Islam, as well as different responses to the military defeat and offers by the TFG to negotiate.

\section{ICU defeat and transformation}

In addition to the military campaign by the TFG and the allied Ethiopian armed forces, there are also underlying societal reasons for the ICU's fragmentation, like centrifugal political segmentation (determined by the complex and everpresent Somali clan-family system), problems resulting from economic competition (land grabs, extortion and control over export products), local political manoeuvring in the stateless environment, and ideological differences rooted in ambivalent Somali nationalism and cultural identities.

While the ICU as such has been dissolved since its defeat, some remnants centred on the militias have slowly reconstituted themselves in the countryside with foreign and local support. And as the ICG noted in 2007, the 'grassroots network of mosques, schools and private enterprises' that was part of the ICU movement and had spread 'the Salafist teachings and their extremist variants remains in place and continues to expand' ${ }^{56}$ This includes Somaliland where

55 Report of the Monitoring Group on Somalia pursuant to Security Council resolution 1676 (2006), UN document S/2006/913, pp. 11-17; Report of the Monitoring Group on Somalia pursuant to Security Council resolution 1676 (2006), UN document S/2007/436; Report of the Monitoring Group on Somalia pursuant to Security Council resolution 1766 (2007), UN document S/2008/274, pp. 20-21.

56 International Crisis Group, Somalia: The tough part is ahead (ICG, Brussels, 2007, Africa Briefing no. 45), pp. 1, 9. 
several of the Al Ittihad and ICU leaders came from ${ }^{57}$ and where Islamists have been working underground to disrupt the prevailing political system.

In January 2007, core remnants of the ICU militias renamed themselves the Popular Resistance Movement in the Land of the Two Migrations (PRM). Two other names also surfaced: the Brigades of Tawhid and the Jihad in the Land of Somalia. They were committed to armed resistance by every possible means and, in the meantime, also developed their commitment to a radical, though not well-elaborated Islamist ideology.

On the political front, the ICU leadership, including what the media always calls the 'moderates', reorganized in Asmara, Eritrea, and formed the Alliance for the Re-Liberation of Somalia (ARS). After being released from Kenyan custody and debriefed by the Americans in early 2007, former ICU head Sheikh Sharif Sheikh Ahmed became the leader, but with Hassan Dahir 'Aweys' still in the background. Initially supporting any kind of armed action against the TFG forces, government officials and the Ethiopians, including shellings, ambushes, targeted killings and suicide attacks, they later chose to negotiate. On 9 June 2008 a deal was struck at a conference in Djibouti by the TFG and the ARS. They agreed to end all violence (on condition that there was a timetable for the departure of Ethiopian troops) and work towards power-sharing and reconciliation. ${ }^{58}$ But this approach lacked significance among the radicalized militias.

The ICU's legacy was notably claimed by a radical sub-group led by the $A l$ Ittihad Al Islami veteran Hassan Dahir 'Aweys', and younger activists like Afghanistan veterans Aden Hashi Farah 'Ayro',59 (of the Ayanle/'Ayr/HabrGidir/Hawiye clan), Mukhtar Robow (Leysan/Sideed/Mirifle/Rahanweyn clan) and Mukhtar Abdirahman (probably a Habr-Ja'elo/Isaaq). The latter three were leaders of a militant group known by the name of Harakat al-Shabaab (or Mujahidiinta/Hizb al-Shabaab, i.e. Fighters/Party of the Youth). This group engaged in systematic attacks on Ethiopian troops and Somalis loyal to the TFG. A campaign of classic urban terrorism was unleashed, resulting in hundreds of civilian victims. al Shabaab was in many respects a continuation of the $A l$

57 When working on this chapter in late 2008, news was received of a fivefold suicide bombing by $A l$ Shabaab-affiliated militants in Somaliland that had left 28 civilians dead and dozens wounded. See 'Suicide bombers kill at least 28 in Somalia' (www.africanews.com/site/Suicide_bombers_kill_28_in_Somaliland/list_messages/ 21336).

58 See 'Agreement between Transitional Federal Government and the Alliance for Reliberation of Somalia (www.iss.co.za/dynamic/administration/file_manager/file_links/SOMALIPAX9JUN 08.PDF?link_id=29\&slink_id=6044\&link_type=12\&slink_type=13\&tmpl_id=3, June 9, 2008).

59 He was killed in an American air strike on 1 May 2008. 
Ittihaad Al Islami movement, and had originally been a militia allied to two radical Islamic courts in Mogadishu (Sherkoolo and Ifka Halane). After defeat in December 2006 it turned to a violent, non-compromising insurrection, led by the figures mentioned above as well as other Islamists. Former warlord Yusuf Mohammed 'Indha'adde' and jihadist Hassan Hersi 'al Turki' followed the same path, although they are not formally part of al Shabaab. They were able to draw support from a network of radical Somali Salafist clerics known for their jihadist pronouncements and statements against westerners, non-Muslims and dissidents. ${ }^{60}$

Al Shabaab-affiliated leaders in the 1990s undoubtedly served as contact men and protectors of (non-Somali) al Qa'eda operatives, ${ }^{61}$ amongst whom were the three involved in the 1998 and 2002 bomb attacks in Kenya. ${ }^{62}$ Al Shabaab thrives on foreign funding from Arab countries and a radicalized/nationalist Somali diaspora. ${ }^{63}$ They thus flout the domestic Somali constituency and feel accountability to no one except Allah. ${ }^{64}$

Despite the pounding the ICU and its militias received from the Ethiopians and the TFG and the unpopularity of their violent political agenda among large sections of the Somali public, including many of the (divided) Hawiye clanfamily, the presence of a radical Islamist social movement in Somalia has now been established. This is in no small part due to support from foreign players, such as Eritrea and some Middle-Eastern Muslim countries, and will be a feature of the Somali political scene for years to come. In the process of their

60 See, for instance, the statements of sheikh Nur Barud Gurhan, chairman of the Kulanka Culimaada, a Salafist group in Mogadishu, in 'Western aid workers accused of conversion', Reuters news message, 22 April 2004.

61 For al Qa'eda's presence in East Africa, see Andre Le Sage, Somalia and the War on Terrorism, Chapter 3.

62 Fazul A. Muhammed (who narrowly escaped arrest in Kenya in September 2008), Saleh Ali Saleh Nabhan, and Tariq Abdullah (Abu Talha 'al-Sudani'). Other alQa'eda men include Ali Swedhan, Samir Said Salim Ba'amir, Mohamed Mwakuza Kuza, Issa Osman Issa and (probably) the Somali Ahmed Abdi Godane. Cf. International Crisis Group, Somalia: Countering terrorism in a failed state (ICG, Brussels, 2002). See also a report on Gouled Hassan Dourad, a Somali detainee in Guantanamo (www.dni.gov/announcements/content/DetaineeBiographies.pdf, September 15, 2008). See also Roland Marchal, 'Islamic political dynamics in the Somali civil war', in A. de Waal (ed.), Islamism and its Enemies in the Horn of Africa (C. Hurst \& Co., London, 2004), p. 139.

63 Cf. Stig Jarle Hansen, 'Misspent youth - Somalia's Shabab insurgents', in Jane's Intelligence Review (http://jir.janes.com/public/jir/terrorism.shtml, September 1, 2008).

64 Cf. Robert Walker, 'Meeting Somalia's Islamist insurgents', BBC news item, (http://news.bbc.co.uk/2/hi/africa/7365047.stm, April 28, 2008). 
(re-)emergence, the social agenda of Muslim movements, including that of the Islamic Courts, has been pushed aside in favour of a religious-political one that is bent on exclusive power and the coercive institution of a new 'moral regime', subverting the civic dynamics of Somali social forces and the agency of established grassroots interest groups.

The ICU and its associates have thus been militarized and transformed by a radical Islamist section that has defeated the aims of the social movement that established it. No doubt the brazen Ethiopian campaign and US anti-terrorism actions like air strikes on militants have contributed to this. But it is also a sign of the fundamental transformations that Somali Islam and its social infrastructure have been going through in the last decade: the decline of authority structures based on clan law and elders, the fragmentation of clans, the emergence of new independent economic power bases, and the rise of a new generation of foreign-funded and supported activists and religious men combating Somali culture, customary law and mainstream Islam dominated by Sufi orders. Apart from the subversion of customary law and the clan elders' influence, this development has marked the weakening of other social forces like traditional socioreligious associations and locally rooted Muslim movements, such as Al Islah and the Ahl as-Sunna wal Jama'a, that recognized the traditional dual nature of power in Somalia ${ }^{65}$ and rejected an exclusivist, politicized Islam, as well as a decline in the fortunes of local NGOs, notably women's groups.

\section{ICU fragmentation and the growth of the jihadist movement}

The dominant insurgent force today is again the al Shabaab which, despite showing some internal diversity, is committed to an al-Qa'eda-type ideology. It has been the most important movement on the ground (up to mid-2009) and has done most of the fighting. It is organized in regional, relatively autonomous units and is becoming rooted in local communities that contribute funds and supplies, either on a forced or voluntary basis. Al Shabaab is trying to fuse Somali nationalism, which appeals to many (provoked by the presence of Ethiopian forces in the country), and radical Islamism conceived in global terms. In 2007, in a script well-known in global jihadist discourse, the PRM started showing suicide-bomber videos online. And in September 2008, some al

65 See Ioan M. Lewis, 'Dualism in Somali notions of power', Journal of the Royal Anthropological Institute, 93 (1963), pp. 109-116. While religious leaders could become involved in (armed) struggle against a perceived external threat, within Somalia this duality was respected and reflected the socio-political organization of society, and political power was not translated or validated in religious terms (Ibid., p. 115). 
Shabaab spokesmen publicly admitted their affinity to al-Qa'eda ideology and were clearly set on the road to terrorism. ${ }^{66}$ Their subsequent shelling of Mogadishu airport and the Ugandan and Burundian AMISOM forces, in which many civilians were killed, confirmed the trend.

Global militant-jihadist discourse has taken root among Somalis and is being spread by foreign-educated clerics and activists (in Saudi Arabia, Sudan, Egypt and the Gulf States), leading many of these groups to propagate a 'pure Islam' and an anti-clan and anti-Somali policy. Several Muslim countries and private individuals are providing funds for Islamic charities, mosques, madrasas and private universities, not to mention other material support including arms and supplies (from Iran, Libya and Syria). ${ }^{67}$ Predictably, the above-mentioned Islamist fighting groups, following the global discourse of jihadist Islamism, started propagandist Internet $\operatorname{sites}^{68}$ calling for jihad and the 'liberation' of Somalia.

The deal made by the ARS with the TFG in June 2008 is evidence of a careful road to rapprochement, but the chance that the radicalized past of the ICU will accept it is slim. It appears to be too late because militant armed elements, such as al Shabaab and related Islamist militias that follow a narrow and uncompromising agenda, are likely to fight on using terror tactics. ${ }^{69}$ They have faced criticism from many of their own clan members, with parts of the Hawiye and Rahanweyn clan-families (where key leaders of al Shahaab come from) disavowing their violent tactics. ${ }^{70}$ In response, al Shabaab activists have targeted those who speak out and assassinated several of them, including clan elders. This development shows that clan dynamics are again impinging on the Islamist agenda and may limit its appeal. Despite this, radical Islamist opposi-

${ }^{66}$ Cf. one of the most notorious al Shabaab leaders, Mukhtar Robow, cited in Ed Sanders, 'Conditions may be ripe for Al Qaeda in Somalia', Los Angeles Times, 25 August 2008.

67 See the report cited in footnote 38, pp. 21-26.

68 See (www.qaadisiya.com), announcing the PRM's formation on 19 January 2007. It soon appeared they were al-Shabaab and were regrouping. Other websites were: www.kataaib.net (the official Al Shabaab site until 23-01-2009, when it was closed down) and www.abushabaab.worldpress.com (in English), also closed down in early 2009.

69 In March 2007 they summarily executed and mutilated several captured TFG soldiers. See 'Somalia, Events of 2007', in Human Rights Watch Report 2008 (Human Rights Watch, Washington, DC, 2008). (http://hrw.org/englishwr2k8/docs/2008/01/31/somali17757.htm, 2008).

70 See for instance, 'Somalia - Mogadishu community leaders appeal to al Shabaab', a news message (www.garoweonline.com/artman2/publish/Somalia_27/Somalia_Mogadishu_comm unity_leaders_appeal_to_al_Shabaab.shtml, October 7, 2008). 
tion forces have been regaining the upper hand on the battlefield as a result of their international connections with other Muslim countries and networks in terms of funds and other support. In late 2008 they occupied the major city of Kismayo and installed an Islamist regime there, including shari'a criminal law. ${ }^{71}$ In December 2008 the announced withdrawal of Ethiopian troops materialized and in early 2009 al Shabaab forces took Baidoa as well. The reluctance of the Ethiopians to perpetually buttress the TFG is explained by the fact that the TFG did not meet their expectations of forming a government, and without the promised support from the AU and the international community, they with drew. The TFG did not succumb to the pressure but saw the resignation of Abdullahi Yusuf and, in a surprise move, the election by an extended Somali parliament of Sheikh Sharif Sheikh Ahmed of the ARS-Djibouti as the new Somali president. His more moderate and conciliatory tone has invited support from Somalis and undermined the support base of the radicals. But the TFG will remain vulnerable, if not succumb, at some point, ${ }^{72}$ and there may still be an Islamist regime in Mogadishu. In March 2009 the new president declared that shari' $a$ would be the main law of Somalia, giving in to another demand by the Islamist radicals. But al Shabaab showed themselves to be rejectionist by not accepting the new TFG under the leadership of their erstwhile ally. Hassan Dahir 'Aweys' of the ARS-Asmara initially rejected the new TFG but in April 2009 announced his intention to return to Mogadishu and conditionally work with the new TFG. However, when he had returned in May, he denounced contacts with the Sheikh Sharif government and called for its removal. As leader of the Hizbul Islam coalition of four smaller radical-Islamist factions, he clearly aimed to become government leader himself. Violence fuelled by al Shabaab and Hizbul Islam actions has continued. It also provoked the formation of militias under the banner of the mainstream Sufist-oriented Ahl as-Sunna wal Jama' $a$ who in early 2009 chased al Shabaab out of several towns in central Somalia. Thus a new round of fighting began, indicating that al Shabaab had reconfigured itself as a militant movement superseding the ICU and was aiming

71 On 28 October 2008 it was reported that they had started to stone Somali women for committing adultery. BBC news message, 'Somali woman executed by stoning' (http://news.bbc.co.uk/2/hi/africa/7694397.stm, October 28, 2008) and 'Rape victim, 13, stoned to death in Somalia', The Guardian, 2 November 2008, (www.guardian.co.uk/world/2008/nov/03/somalia-rape-amnesty, November 2, 2008).

72 See Steve Bloomfield, 'Troop pull-out leaves government on brink', Sunday Herald, 11 October 2008. The ongoing offensive of the al Shabaab, supported by terror attacks, brought this moment near in June 2009. 
to achieve its goals (of gaining power and installing a theocratic state) through violent means rather than a broad social programme.

\section{Conclusion: The transformation of a social movement}

The ICU and its constituent parts undoubtedly had traits of a grassroots social movement by being involved in dispute resolution and exercises in social justice and attempts to restore some degree of social order. It certainly was, to cite Olzak's definition, 'a purposive collective movement voicing demands for fundamental changes in society, mobilizing around one or more public causes and following a strategy of change'. ICU activities could be claimed to have been beneficial to an urban constituency and came to stake claims for fundamental change in a wider national arena, although they were not al all democratic. The fact that in 2006 this movement quickly went on to take economic and political functions and violently claim exclusive socio-political space was because the state in Somalia had not only collapsed but had effectively dissolved so that the movement - and its religious currents - had no political structures or powerful state adversary to confront, unlike social movements in Europe, Latin America or South Africa. The ICU had to fill a vacuum to not only provide services but also create new narratives of legitimacy and authority. It decided to seek a basis in Islam, offered as an encompassing, absolutist ideology claiming to fill civic space and ground people's social identity. But any social movement, as an invented institution, is prone to change and metamorphosis, as Tilly noted. ${ }^{73}$ That the ICU allowed itself - perhaps having no choice on a playing field dominated by violent competition for power and allegiance and no other 'unifying' discourse than Islam available - to be taken over and dominated by radical Islamists as to leadership and political ideology was a result of its inexperience and its unclear, perhaps underdeveloped, socio-political programme. It was likely also a reflection of the basic impossibility of developing a real political Islam. Many in Somalia feel this to be a contradiction in terms, notably in view of the deeply engrained duality of notions of power in Somali culture - the religious people (wadaad) versus the politicians or warriors (waranle). ${ }^{74}$ Political power is, furthermore, usually seen as corrupting religious values, and perhaps vice versa. It is the old problem that beset Sayyid Mohammed Abdulleh Hassan back in the early 1900 s. $^{75}$

73 Tilly, Social Movements, p. 14.

74 Cf. Lewis, 'Dualism in Somali notions of power', p. 114.

75 Cf. J. Abbink, 'Dervishes, moryaan and freedom fighters: cycles of rebellion and the fragmentation of Somali society, 1900-2000' in J. Abbink et al. (eds), Rethinking 
The social movement of the ICU has fragmented and lost direction. The broader-based ARS has taken its place since 2007 as a political opposition force but as such was not present in Somalia. The courts could regain legitimacy and make an impact by refocusing on what they do best, namely dispensing justice in local social and other disputes, seeking reconciliation and accommodation between different groups and clan units, and refraining from politicizing their role. In these domains they can still do more than the perennially weak, erratic and unreliable TFG, which has not been able either to institutionalize itself or gain sufficient loyalty ${ }^{76}$ and work towards national inclusiveness. It has the character of a phantom government without a social presence and with its various units like the army, police or security forces often operating fully on their own and not responding to the cabinet ministers who are nominally in charge. Its record of abuse and the bad name its Ethiopian allies have inevitably received in Somalia due to the ongoing violence are preventing progress. A compromise formula between the two - the TFG and the ARS - is inevitable but realities on the ground have so far prevented this.

The ICU movement yielded various moderate as well as militant/violent parts in 2008, with the latter subverting anything good that the ICU had achieved when in power in Mogadishu. Among them, al Shabaab turned in fact into an 'anti-social movement', targeting its own people and predictably rigidifying its policies with, as the core issue, the unconditional withdrawal of the Ethiopians (thereby hoping that an implosion of the TFG would follow) and the coercive establishment of shari'a rule in a theocratic state. Beyond this, no specific political ideas have been voiced. For them, all means to these ends are justified. The following incident is characteristic:

On 7 October 2008 the chairman of a traditional elders' council in the Hiraan region, Mr Da'ar Hersi Hoshow, was shot and killed. Hundreds of protesters took to the streets in Beletwein, the capital of Hiran, following the assassination. The protest turned violent with demonstrators throwing rocks at Islamic Courts fighters, who effectively control Beletwein and the surrounding regions after Ethiopian troops withdrew last month [September 2008]. No group claimed responsibility for the murder, but the assassination came a day after he publicly renounced the al Shabaab insurgents' threats against the aid agencies CARE International and International

Resistance: Revolt and Violence in African History (Brill, Leiden, 2003), pp. 328365; and Hussein, From Tyranny to Anarchy, p. 76, 221.

76 Although it probably commands the nominal allegiance of the majority of southern Somalis: the Darod and Rahanweyn clan-families, the larger part of the AbgalHawiye clan, and many minority groups. 
Medical Corps. He had also suggested that al Shabaab's threat was intended to 'starve' the local people. ${ }^{77}$

This killing, not the first to be directed against a legitimate social current in Somali society, namely the clan elders who represent legitimacy and authority in the local context, confirms that Islamist radicals have taken over the struggle and annexed the social-movement element in Somali insurgency. Clan-family divisions and competition for power and resources of any kind (money, guns, land, water and women) have come to dominate the struggle in southern Somalia based on earlier struggles in the 1990s and are not easily resolved. ${ }^{78}$ This is reminiscent of the deep divisions and violence left by Sayyid Mohammed Abdulle Hassan, the anti-colonial militant and proto-nationalist of the early twentieth century. ${ }^{79}$ It took decades to overcome the damage done by his Islamist armed movement and the current antagonisms in Somalia may indeed have revived the conflict and memories of the divisions he generated.

The present conflict shows that the ICU, which originally emerged as a partial solution to the challenges of social disorder and the problems of degenerated clan mediation mechanisms and failing social support systems in Somalia, has been overtaken by a radical Islamist ideology based on foreign models. This ideology is carried by certain clan groups and elites within those clan groups more than by others. The clan system is not, as often alleged, inherently divisive (see the experiences in Somaliland and Puntland) but only becomes so when Islamist ideology is let loose on it. The Islamist politicization of the country's problems has subverted the courts' potential and their socially reconstitutive role. It has made a particular form of Islam dominant: the Salafistjihadist version that fuses religion and politics in a violent narrative, presenting armed force and terror as the apocalyptic means to the goal of Islamist theocratic rule, and which is not popular among most Somalis. This has prevented authentic social movements from developing.

The result appears to be a Somali society more divided than ever and one burdened by a discourse of violence and revenge. There is a Somali saying that

77 Based on the news story 'Somalia: chairman of elders' council assassinated in central Somalia' (http://allafrica.com/stories/200810080085.html, October 7, 2008). Since October 2008 and in a fully predictable scenario, there have been many other reports of the stoning of rape victims, the cutting off of thieves' hands and even the beheading of sheikhs by Al Shabaab forces. One example is Abdi Sheikh and Abdi Guled, 'Somali Islamists behead two sheikhs' group', Reuters news message, 20 March 2009.

78 See Ken Menkhaus, Somalia. A Country in Peril, a Policy Nightmare (ENOUGH Project, Washington, DC, 2008) (www.enoughproject.org/files/reports/somalia_rep090308.pdf).

79 See Abbink, 'Dervishes, moryaan and freedom fighters', p. 346. 
goes as follows: Nabar doogi ma haro ('An old wound will not go away'). If this is true, the Somalia conundrum, which is following a historically familiar cyclical pattern of group rivalry and violence, will probably be with us for another generation at least. 


\title{
Liberia's women acting for peace: Collective action in a war-affected country
}

\author{
Veronika Fuest
}

This chapter explores the historical and socio-political factors that have facilitated the emergence of the women's peace movement in Liberia, which has been credited with the election of the first female African head of state. It highlights specifics of the country's settler history, of autochthonous/indigenous constellations of gender relations, and precursors of women's collective action. On the one hand, shared experiences of the civil conflict have activated the potential for female modes of organization. On the other hand, 'identity work' by the leadership of the movement, which was instrumental and indispensable in bridging internal class, ethnic and other divides, has also been informed by international feminist discourse. Special attention is devoted to the role of the international community and the national government in shaping the structure of political opportunities, allowing for the emergence, maintenance and transformation of the movement.

\section{Introduction}

In 2005, Liberian voters chose a woman, Ellen Johnson-Sirleaf, to be their president. This has generated worldwide interest. The first-ever election of a female head of state in Africa can be seen as a sign of a wider social movement associated with peace. Indeed, a number of scholars have credited women's organizations with exceptional social inclusiveness and a concomitant potential for peace-building.

The fact that gender identities play an important role in determining levels of trust with much higher levels of trust in women-dominated organizations than in those 
dominated by men - has important implications for the potential role of different organizations in rebuilding social capital ...

This chapter explores the factors that have facilitated the emergence of the women's peace movement in Liberia, including specifics of the country's history and processes of 'identity work', ${ }^{2}$ and discusses some of the aspects of its social range and internal divisions. Special attention is devoted to the role of the international community and the national government in shaping the 'structure of political opportunities ${ }^{3}$ concerning the emergence, maintenance and transformation of the movement.

After the outbreak of civil war at the beginning of the 1990s, Liberia witnessed the formation of a number of women's organizations. These appear to have increased exponentially particularly since the end of the conflict in 2003. Various informal women's organizations at the local level have emerged in response to local problems and offer self-help in areas of, for example, joint production, reconstruction, marketing, security, 'trauma healing' and traditional skills training. To some extent, the flourishing of women's groups reflects entrepreneurial attempts to gain access to donor funding in general, and some of the local organizations have been established in response to aid agencies' frequent preference to channel funding to women's groups. In Monrovia and other cities in the centre and northwest during the war, women were highly visible 'as activists for peace and as agents of reconciliation'. ${ }^{4}$ Leaders and members of these organizations worked across faction lines and acted as mediators, often at great personal risk. They organized marches, formulated petitions and attended national and international conferences. ${ }^{5}$

1 C.O.N. Moser \& F.C. Clark (eds), Victims, Perpetrators or Actors? Gender, armed conflict and political violence (Zed Books, London/New York, 2001), p. 10. Cf. also Swanee Hunt \& Cristine Posa, 'Women waging peace', Foreign Policy, May/June (2001), pp. 38-47; and K.H. Karamé (ed.), Gender and Peacebuilding in Africa (Norsk Utenrikspolitisk Institutt, Oslo, 2004).

2 David A. Snow \& Doug McAdam, 'Identity work processes in the context of social movements: Clarifying the identity/movement nexus' in: Sheldon Stryker et al. (eds), Self, Identity and Social Movements (University of Minnesota Press, Minneapolis, 2000), pp. 41-67.

3 Cf. Jacquelien van Stekelenburg \& Bert Klandermans, 'Social movement theory: Past, presence and prospects', in this volume.

4 Mary H. Moran \& M. Anne Pitcher, "The "basket case" and the "poster child": Explaining the end of civil conflicts in Liberia and Mozambique', Third World Quarterly, 25, 3 (2004), p. 506.

5 Nadine Puechgirbal, 'Involving women in peace processes: Lessons learnt from four African countries (Burundi, DRC, Liberia and Sierra Leone)', in K. Karamé (ed.), Gender and Peacebuilding in Africa, pp. 47-66; African Women and Peace Support Group, Liberian Women Peacemakers: Fighting for the right to be seen, heard, and counted (World Press, Trenton, NJ, 2004). 
When considering the emergence of Liberian women's groups, it can be seen that, according to Tilly, there are three main elements to a social movement: campaigns (a sustained, organized public effort making collective claims on target authorities); a repertoire (the employment of different forms of political action involving associations and coalitions, public meetings, processions, vigils, rallies, demonstrations, petition drives, statements to and in the public media, and/or pamphleteering); and the concerted public representation by participants of unity, numbers and commitment. ${ }^{6}$ These elements were all operative in the organized actions of Liberian women during and after the civil war. ${ }^{7}$ Various external observers have agreed that, compared to other countries, there has been an extraordinary degree of determination and militancy in the Liberian women's peace movement. And this was years before Ellen Johnson-Sirleaf was elected as Africa's first female head of state in 2005. For example, Moran reports that anthropologists in the 1990s were struck by the democratic nature of the gender dialogue and the 'empowered females'. ${ }^{8}$ In a comparative article, Moran and Pitcher noted 'that there was far more peace-oriented activity by explicitly women's organisations going on in Liberia; furthermore, these organisations existed at all levels from the most powerful urban elites to illiterate villagers'. ${ }^{9}$ More recently, the Liberian women's peace movement was given international recognition in the film entitled Pray the Devil Back to Hell. ${ }^{10}$

Research was undertaken in the capital, Monrovia, and in urban and rural locations in the northwest, centre and southeast of Liberia (in Bong and Lofa counties from 2005 to 2007, and in Grand Gedeh and Sinoe counties in 2008). Participant observation was used at village meetings, gender workshops and at a women's conference, and interviews were held with business women, male and female farmers, urban residents of all ages and key informants such as leaders of women's organizations, local and national politicians, development agencies and staff working for non-governmental organizations (NGOs). ${ }^{11}$

The results presented here acknowledge the complexities of the social differences and divisions in Liberian society. Firstly, the people living in Liberia's north, centre and west can be distinguished as being socio-politically, ecologically, agriculturally, linguistically and demographically different from the

6 C. Tilly, Social Movements, 1768-2004 (Paradigm Publishers, Boulder, CO, 2004).

Cf. African Women and Peace Support Group, Liberian Women Peacemakers.

8 M.H. Moran, Liberia. The Violence of democracy (University of Pennsylvania Press, Philadelphia, 2006), p. 43.

9 Moran \& Pitcher, "The "basket case" and the "poster child", p. 504.

10 Fork Films (http://www.praythedevilbacktohell.com/nonflash/about.htm, October $22,2008)$.

11 The author is grateful to the Max Planck Institute for Social Anthropology, Halle/Saale, Germany, and to the Welthungerhilfe for providing funding for field research. 
population in the southeast. ${ }^{12}$ Liberia's northwest and centre constitute the socalled Mande-speaking 'Poro complex' of secret societies, a region historically marked by a distinct socio-political system of ranked lineages with powerful elders or chiefs and gendered, mutually exclusive, secret societies, colloquially known as Poro (for the male society) and Sande (for the female society). By contrast, the Kruan-speaking groups in the southeast are characterized by acephalous communities, less important secret societies and the institutionalized participation of women in traditional government. ${ }^{13} \mathrm{~A}$ second important dimension of socio-political variation is constituted by Liberia's history of 'black colonialism', which is considered unique in Africa. Descendants of freed slaves that were resettled from the US and elsewhere in the nineteenth century founded Africa's first republic in 1847 and, as a small minority, they dominated the country's political, social and economic life for more than 130 years. These socalled Americo-Liberians and 'Congos' (the name originally given to slaves intercepted while being illegally transported on the high seas, and put ashore in Liberia) fought, suppressed, exploited, traded and mixed with various African groups and constituted the country's ruling elite. A coup d'état in 1980 brought Afro-Liberians to power and the ensuing corrupt and repressive government, dominated by the president's ethnic group, was overthrown by 'rebel' forces that invaded Liberia under Charles Taylor in 1989 and ignited a civil war that would last for fourteen years.

Social and political antagonisms between Americo- and Afro-Liberians in the twentieth century were reflected in the social distinctions that emerged involving the label 'civilized', which is a notion loaded with religious and moral meanings and became an important identity marker of contextual claims to elite membership. ${ }^{14}$ Thus historically, Liberia's women, and men for that matter, were both divided and united by a dichotomy juxtaposing educated/'civilized'/ 'Congo' (Americo-Liberian) with 'country'/'traditional'/'native' identities. Indigenous Africans had limited access to certain elite positions through formal education and assimilation into the Christian settler community, as a result of which they too could acquire a 'civilized' identity.

Thirdly, the war resulted in an emphasis on religious antagonisms between the Christian and Muslim sections of the population, and ethnic polarization.

12 For example, Warren L. d'Azevedo, 'Some historical problems in the delineation of a central west Atlantic region', Annals New York Academy of Sciences, 96 (1962), pp. 512-538.

13 Moran, The Violence of Democracy.

14 Elizabeth Tonkin, 'Model and ideology: Dimensions of being civilized in Liberia', in L. Holy \& M. Stuchlik (eds), The Structure of Folk Models (Academic Press, London, 1981, ASA Monograph 20), pp. 307-330. 
Two of the major warring factions were constituted by an ethnic group with a predominantly Muslim identity.

\section{Concerns of women's organizations}

Social movements offer an important vehicle for ordinary people's participation in public politics. In the sense of 'politics by other means', they may constitute the only means open for relatively powerless groups to challenge the dominant political structures or processes and the distribution of resources. ${ }^{15}$ The distinction between the practical and strategic needs of women, first delineated by Molyneux, ${ }^{16}$ seems useful in capturing the heterogeneous currents and concerns of the movement under discussion here. 'Practical needs' addressed by the selfhelp organizations (and many NGOs) include the most pressing basic needs for safe shelter, adequate nutrition, health care, clean water etc. By contrast, strategic needs address women's institutional opportunities and status in society, such as legal protection, access to education, employment and land rights, and an end to gender violence. By extension, they include the end of fighting in times of war. The organizations devoted to peace activism and later to political advocacy have been the motors of the women's peace movement. The following sections illustrate the scope and activities of the movement.

The Association of Female Lawyers in Liberia (AFELL), the Mano River Union Women Peace Network (MARWOPNET), and the Women in Peace Building Network (WIPNET) are among the most influential and visible organizations. ${ }^{17}$ AFELL was established in 1994 to offer legal assistance to women and children who had suffered from violence and has effected the passing of two laws: the Act to Govern the Devolution of Estates and Establish the Rights of Inheritance for Spouses of Both Statutory and Customary Marriages (2003), in short the 'inheritance law' that aims to regulate women's marriage rights, rights to property and access to their children after divorce or the death of their spouse, and the 'rape law' (2006), which has turned rape into an non-bailable offence. MARWOPNET was established in 2000 by women peace activists from Guinea, Sierra Leone and Liberia on the occasion of a conference in Conakry of the regional economic grouping, the Economic Community of West

15 Cf. the contribution by Habib \& Opoku-Mensah in this volume.

16 M. Molyneux, 'Mobilization without emancipation? Women's interests, the state, and revolution in Nicaragua', Feminist Studies, 11, 2 (1985), pp. 227-254.

17 Other organizations are the Liberian Women's Initiative (LWI), the Women of Liberia Peace Network (WOLPNET), Concerned Women for Liberia (CWO), Women in Action for Good Will, the Muslim Women's Federation, the United Muslim Women's Advocacy and Empowerment Organization (UMWAEO), the Muslim Women's Association for Peace and Social Justice, and the Coalition of Women of Political Parties in Liberia (CWPPL). 
African States (ECOWAS). Internationally, it has been the most visible of Liberia's women's organizations as it was given considerable attention by the media and international agencies, and was awarded the United Nations Prize in the Field of Human Rights. ${ }^{18}$ Without invitation, this organization produced a declaration during the peace negotiations in Accra in 2003. The women demanded inclusion in peace negotiations in line with the Resolution on Women, Peace and Security (SC Resolution 1325) adopted by the UN Security Council in 2000, which formally recognizes women's particular vulnerability in wartime and calls for their equal participation and full involvement in peace-making. WIPNET was founded in 2002 under the auspices of the West African Network for Peacebuilding (WANEP) and has been Liberia's most comprehensive women's organization with over 5,000 members in all of the counties involved in it. WIPNET's strategic goals have dominated from the start and its activists are acutely aware that external aid projects differ in their objectives or in the strategies they employ to achieve improvements in women's lives. They question well-meaning training programmes for women that pass on traditionally Western female skills and occupations.

WIPNET and MARWOPNET are umbrella organizations that have both made a special effort to embrace women from all ethnic and socioeconomic backgrounds to expand their basis for mass action, especially at the famous peace demonstrations in April and May 2003. Some activists have taken steps to narrow the social gap, for example by discouraging the use of 'big English' at meetings, workshops and conferences, which the 'civilized' habitually use to distinguish themselves from the 'country people'. Representatives of rural women have been consciously included, facilitation methods have been adapted to the needs of illiterate participants and interpreters provided for those lacking a good command of English. MARWOPNET's leaders determinedly took illiterate rural women to the Mano River Union conference in Conakry in 2001, to the astonishment of representatives from other countries, and WIPNET has also pointedly included women of different religious denominations in its organization in an attempt to reduce the dominance of Christian activists in NGOs. In practical terms, for example, Muslim women leaders have frequently been asked to deliver the opening and/or closing prayers at workshops and conferences.

The movement has commanded a range of symbolic resources on which the existence of shared identities depends. ${ }^{19}$ In addition to slogans and songs, the women wear white T-shirts and white head-ties as symbols of their unity during their peace campaigns. Liberia's 'women in white' or 'white women' have been

18 Puechgirbal, 'Involving women in peace processes'.

19 Snow \& McAdam, 'Identity work processes in the context of social movements'. 
active conflict mediators in the years since the war and are widely recognized beyond national boundaries. At the WIPNET conference in May 2006, the founder of WANEP, a key speaker, stressed that whenever he travelled outside Liberia, he felt 'proud of being recognized by the white T-shirt women and the football star George Weah'. On International Women's Day in March 2007 and in 2008 the white T-shirts could still be seen at marches in Monrovia and in the distant coastal city of Greenville.

After the 2003 peace agreement, the main goal of the movement shifted to demands for the institutionalized political and economic participation of women, and the radical stance taken by organizations such as WIPNET in favour of strategic needs seems to have been accepted by the Ministry of Gender and Development (MGD). Women activists have lobbied for legislative reforms to reserve at least 33 per cent of all seats in local and national elections for women. They have demanded balanced employment, law enforcement, access to and ownership of land, and training for legal staff such as land commissioners. They advocate special leadership training programmes for women and girls and are encouraging more female candidates to contest local elections that are scheduled for 2009. An emergent class of business women, which formed in the entrepreneurial vacuum during the $w a r,{ }^{20}$ seems to be accommodating its interests within the movement too. Credit programmes and training to advance female entrepreneurship are also being called for. Pointing specifically at the constraints women face in the lucrative cross-border trade, a recent policy paper addressed the harassment women face from customs and immigration officers and demanded that gender-sensitive training manuals be developed for all officials working at border posts. ${ }^{21}$

\section{Formative and supporting factors}

The formation of novel gender stereotypes, the maintenance of a collective female identity and the organization of activities have been nurtured by factors including internal identity politics and external markets. An obvious example is that the pattern, speed and spread of a movement depend on a functioning communications network. Communication has been vastly facilitated by the

20 V. Fuest, "This is the time to get in front". Changing roles and opportunities for women in Liberia', African Affairs, 107, 427 (2008), pp. 201-224.

21 WANEP \& WIPNET, Women's National Agenda for Peace, Security and Development in Post-War Liberia. Adopted 30 March 2006, presented to the Government of the Republic of Liberia (Women in Peacebuilding Network, Monrovia, Liberia); Ministry of Gender and Development and the United Nations, National Women's Conference Report: Advancing women in peacebuilding, recovery and development in Liberia (Monrovia, 5-9 May 2008). 
exponential spread of mobile phones since the end of the war. Social networking in general has been dramatically transformed by this technology and is an area of study that merits further investigation. However, as a social category, women have had reasons for relating to the war in particular ways. The following sections differentiate for heuristic purposes three domains that intersect both conceptually and in (social) practice and that have contributed to the forming and maintaining of the movement.

The socioeconomic and political roles of Liberian women vary in many ways, the most obvious dimensions being generation, lineage status in the northwest, age-group identity in the southeast, and ethnic belonging including the Americo-Liberian sub-sections of society. However, images and practices central to the movement - of women as leaders and female collective action have been built on traditionally cultural and social capital. As many scholars have demonstrated, ${ }^{22}$ social movements typically emerge out of existing organizations and associational networks.

Firstly, Liberian society has always conceived women's agency and their collective action as being essentially separate from the realm of men. Moran stressed the importance of the traditional 'dual-sex' organization in Liberia, and for that matter in West African societies:

Women simply do not view men as capable of representing them and their interests. At one level, this conviction may stem from the highly segregated nature of women's and men's productive activities in West African farming systems. Although complementary, these separate tasks may bring women and men into competition for such resources as land and labor. More important, however, may be the cultural constructions of women and men as radically different kinds of beings, manifest in such structures as the dual-sex political system, which underlies the belief that men cannot adequately represent women and vice versa. ${ }^{23}$

This dual organization of the sexes has not prevented women's organizations from the time-consuming consultation of powerful and knowledgeable senior males in times of need either in the past or the present. (Leaders of the women's secret society have also been accountable to male seniors of the Poro.) The fact that one of WIPNET's founders is male can be attributed to his network connections within West Africa, which have been useful in eliciting support from the West African Network for Peacebuilding (WANEP).

Secondly, Liberian women historically organized a wide range of collective activities in different contexts. The most influential traditional organization, which involved trans-ethnic inclusive activities, was the Sande in the country's northwest. In southeastern Liberia women organized themselves traditionally

22 Cf. Snow et al., 'Identity work processes in the context of social movements'.

23 Moran, 'Collective action and the "representation" of African women: A Liberian case study’, Feminist Studies, 15, 3 (1989), p. 444. 
and supported their women's chief and councils of female elders, which are parallel institutions to the male-dominated structures in local politics.

Thirdly, notwithstanding ideologies of male dominance and corresponding institutions of social control, Liberian history has encompassed powerful women in both 'traditional' and 'modern' settings. Looking at the historicity of the status of women in other African countries, it could be suggested that the colonial 'disempowerment' that women suffered in other countries was not present in Liberia.

Female power in local public realms has, therefore, been a traditional feature in Liberia, notwithstanding women's structural constraints within a traditional system that has generally been labelled 'wealth-in-people' in a generalizing perspective inspired by political economy. Where labour has been a crucial political and economic resource in environments with a relative abundance of land, powerful men have accumulated women, the major workforce, and controlled and redistributed women's sexual and reproductive services to establish political alliances and win clients. Accordingly in Afro-Liberian societies, women's reproductive capacities and labour have been controlled by their lineage elders and their husbands' lineages. ${ }^{24}$

Women in the southeast of Liberia tend to perceive men and women as different and complementary instead of the latter being inferior. The 'cultural ideal woman is the hardworking wife and mother, the provider for her household. The ideal husband is generous and is expected to provide his wife or wives with gifts .... ${ }^{25}$ In the southeast, parallel political structures for men and women in village governance have existed and survived, ${ }^{26}$ involving institutions like 'women's chiefs' and councils of female elders with a deliberative role and the power of veto over certain decisions made by male councils. (For example, over-enthusiastic warriors in the past could reportedly be checked by the women's council.) ${ }^{27}$ Such institutions have been absent in the more hierarchically organized societies of the north and west. Evidence suggests that among the Kpelle, for example, women have always been considered inferior to men. The dominant ideology of male superiority has centred on the male role of protection, support for women and provision for their children. ${ }^{28}$

24 C.N. Bledsoe, Women and Marriage in Kpelle Society (Stanford University Press, Stanford, 1980).

25 Moran, 'Collective action and the "representation" of African women', p. 453.

26 V. Fuest, Contexts of Conflict in Southeast Liberia. A study report (Welthungerhilfe, Bonn, 2008).

27 Moran, The Violence of Democracy, pp. 40-48, 147-148.

28 S. David, "You become one in marriage": Domestic budgeting among Kpelle of Liberia', Canadian Journal of African Studies, 30, 2 (1996), pp. 157-182. 
In the northwest, traditionally gender-specific codes of behaviour have been transmitted by the secret societies. Boys' and girls' initiation, involving circumcision, was compulsory, with seclusion in so-called 'bush schools' that were separated by gender and originally lasted for several years. Sande and Poro leaders cast themselves as brokers and exclusive ritual managers between the realms of male and female and between the supernatural and daily life. Marriage and reproduction were mediated by the elder female leaders of secret societies who claimed to be in spiritual control of the well-being and reproductive capacities of initiated girls. Sande leaders and important members, such as midwives, could extract considerable fees and labour services from senior relatives of the initiates and their prospective husbands. Such entitlements were based on claims to command esoteric skills and knowledge enabling them to control a girl's fertility and health. ${ }^{29}$ Although women as a class could not adopt any public political roles, individuals and particularly those belonging to ruling lineages could command space for socio-political manoeuvring. They could, for instance, generate considerable power by playing 'the male game' of controlling male and female junior dependents and securing male labour and allegiance. ${ }^{30}$

The traditional principles of hierarchical organization - gerontocracy, lineage status, patriarchy - became increasingly negotiable as they were crosscut by other principles evolving from the differentiation of Liberian society in the course of the twentieth century, such as formal education, employment in the public sector and access to the higher echelons of Liberian networks of patronage. Notwithstanding the dominant patriarchal ideology in Liberia, there was a comparatively large population of educated, professional women when the war broke out. Probably due to the heritage of matrifocality in the (former) slave families from the United States, Liberia's settler women enjoyed social and economic privileges/rights unheard of in the Western world of the nineteenth century. And since the middle of the twentieth century Liberia has revealed a striking representation of women in public office. ${ }^{31}$ From the 1950 s onwards, President Tubman carefully cultivated a new constituency among women, extended suffrage to women and appointed some to positions of authority, ${ }^{32}$ and his supporters organized a women's political and social movement.

There have been precedents for collective female action as well as inclusive organizations. The historical experience of female pressure groups concerned with the good of the community can be seen as being grounded in a tradition of

29 C.N. Bledsoe, 'Stratification and Sande politics', Ethnologische Zeitschrift Zürich, 1 (1980), pp. 143-150.

30 Bledsoe, Women and Marriage.

31 For details cf. Fuest, "“This is the time to get in front"”.

32 A. Sawyer, The Emergence of Autocracy in Liberia. Tragedy and challenge (Institute for Contemporary Studies, San Francisco, 1992), pp. 280, 371. 
women's collective action/mass protest in Liberia's southeast since pre-war times. The position of women chiefs has required support from collective female action; having a voice but not an equal voice requires women to act collectively to counteract the power of a political hierarchy in which they are junior partners. ${ }^{33}$

The Sande seem to have fostered an ideology of solidarity among women and female strength in the face of male harassment, inasmuch as certain skills for manipulating men were passed on at initiation and consolidated action was mobilized against men who transgressed society's rules. Initiated peers (of the same status) are reported to have practised mutual help in times of need. However, it is doubtful that the Sande asserted anything like local 'women's rights' in any institutional sense. Occasional enactments of solidarity seem to have been counterbalanced by the hierarchical cleavages within society and the interests of the leaders in enriching themselves, including the fabrication of charges of wrongdoing against men to create occasions for fines. ${ }^{34}$

Women's organizations with their various tasks in the agricultural cycle have existed since time immemorial. All over Liberia there are seasonal work cooperatives, for which the Kpelle term kúu has become a generic designation in Liberian English. Women's associations have long been a traditional feature of urban social life and women's savings and marketing cooperatives have been recorded since the middle of the twentieth century. In particular, church-based women's organizations of different denominations have provided an important site of cross-class, interethnic contact and collaboration. In Liberia's southeast, voluntary associations have generally been of greater significance than in the northwest. Beyond savings and loan cooperatives (susu), women's clubs also meet to save for entertainment, funerals and social insurance..$^{35}$ Evangelical and independent churches engaging in charitable and self-help activities multiplied in the 1980 s as a result of increasing poverty and social polarization, with the majority of members being recruited from among the increasing numbers of urban women in the informal sector. ${ }^{36}$

33 Moran, The Violence of Democracy, p. 48.

34 C. Bledsoe, 'The political use of Sande ideology and symbolism', American Ethnologist, 11 (1984), pp. 455-467.

35 Hans D. Seibel \& Andreas Massing, Traditional Organizations and Economic Development. Studies in indigenous cooperatives in Liberia (Praeger Publishers, New York, 1974).

36 Paul Gifford, Christianity and Politics in Doe's Liberia (Cambridge University Press, Cambridge, 1993), pp. 288-291. 


\section{Shared experiences of the war: Identity enhancement and identity politics}

Experiences of gender-specific violence have become a collective concern requiring measures to mobilize mutual help and external support. Different sources agree that about 70 per cent of women and girls experienced sexual violence during the war. ${ }^{37}$ The peculiar paradox that increasing numbers of incidences of rape may correlate with a growth in women's organizations and women's status has been noted by Ibeanu with respect to Nigeria. In her study, many Ogoni men and women ( $61 \%$ and $82 \%$ of respondents) felt that a violent crisis raised the profile of women and their confidence to deal with problems confronting them and their community, and generally enhanced respect for women who are praised for their positive contributions. As a result, a number of traditional stereotypes about women have been challenged, such as their weakness and submissiveness. ${ }^{38}$

Liberian women's self-confidence seems to have increased too, challenging the traditional ideology of male superiority. ${ }^{39}$ Urban as well as rural women stress that the experience of war made them realize that they were 'in the dark' before and are now 'waking up to the issue of leadership'. Many women are conscious, if not proud, of having coped during the war with crises without male support. They assumed responsibility for tasks previously performed only by men and they learned new skills such as brick making, building and roofing houses, and clearing farms. The war opened up new spaces for collective action. Local narratives refer to women who organized themselves to ensure their community's survival, mediated conflicts involving local (war) leaders, and/or calmed trigger-happy fighters. Women appear to have developed special negotiating powers with commanders, who could have perceived them as less threatening than men. Women were certainly able to organize crossing the lines of fighting more easily than men. And most significantly, an increase in women's political ambitions and in the legitimacy of women's political participation at national and local level seems to have been increasingly accepted by the male sector of the population. In view of what has been perceived (and constructed) as overwhelming evidence of men's multiple failures during the

37 See, for example, Simone Lindorfer, Assessment Report Liberia. Sexual and genderbased violence in Grand Gedeh, River Gee and Sinoe (Medica Mondiale, Monrovia, 2005).

38 Okechukwu Ibeanu, 'Healing and changing: The changing identity of women in the aftermath of the Ogoni crisis in Nigeria', in Sheila Meintjes et al. (eds), The Aftermath. Women in post-conflict transformation (Zed Books, London, 2001), pp. 189209.

39 Cf. also F. Olonisakin, 'Women and the Liberian civil war', African Woman, MarchSeptember (1995), pp. 19-24. 
conflict, women's social and economic achievements and their impressive contributions to the common good during the war are discursively being emphasized. Female refugees were exposed to novel practices and ideas during their time in exile in other West African countries. ${ }^{40}$ As an essay in informed speculation, I suggest that the sheer spatial extension and intensity of the Liberian civil war as well as the long-term displacement of at least half of the population resulted in particularly extensive experiences in new female roles.

As with social movements elsewhere, Liberia's women's movement is constituted by a bundle of narratives. Positive, binding functions demand audiences to concur and respond emotionally and produce comparable stories. Shared experiences are traditionalized through discourse grounded in moral expression. The recognition of a set of shared, repeated and meaningful references results in a collective identity that facilitates collective action. ${ }^{41}$ Discourses around the experience of rape have contributed to the conceptualization of women as victims and as a group in need of special assistance. This aspect of humanitarian aid and solidarity (involving the formation of victim-perpetrator dichotomies) has been nurtured by support from the churches and by international NGOs since the early 1990s. Other references include stories of mutually achieved success as single providers for their families, and constructions from the past and present in terms of power structures characterized by gendered suppression. Women are not only the victims of rape: Liberian women are, retrospectively, also construed to have been mere objects of exploitation by men and treated like chattels in traditional society. ${ }^{42}$ Their capabilities as (better) leaders surfaced during the war. (Women activists rarely mention particularistic interests or divisive practices such as the suppression and exploitation of young women by female elders.) In principle, groups and individuals can be seen to be drawing on a repertoire of positions and arguments. The traditional image of the modest, pious, unthreatening woman, the role of the peaceful mother and the caring household provider may be discursively emphasized in certain public situations, and the image of women as political animals with legitimate claims to power

40 V. Fuest, Fruits of war? Refigurations and Contestations of Female Identities in Liberia. Working Paper of the Max Planck Institute for Social Anthropology (Max Planck Institute for Social Anthropology, Halle/Saale, forthcoming); Fuest, "'This is the time to get in front"'.

41 Gary A. Fine, 'Public narration and group culture: Discerning discourse in social movements', in H. Johnston \& B. Klandermans (eds), Social Movements and Culture (University of Minnesota Press, Minneapolis, 1995), pp. 127-143.

42 Cf. Government of Liberia, Act to Govern the Devolution of Estates and Establish the Rights of Inheritance for Spouses of Both Statutory and Customary Marriages (Monrovia, 2003). 
(based on human rights) in others. Most of these images resonate with those of the 'civilized' woman, which have been analyzed by Moran. ${ }^{43}$

The point of departure of the women in the peace movement was the realization that 'men were at the root of the war'. ${ }^{44}$ The Minister of Gender and Development argued at a conference in June 2005 that:

... evidence has shown that women's participation in political decision-making bodies improves the quality of governance. Studies have also shown a positive correlation between increased women's participation in public life and a reduction in the level of corruption. ${ }^{45}$

The image of peaceful women-in-leadership - which is also essentializing in substance - is being activated to support claims to political leadership: women are needed as leaders to secure enduring peace and good governance. MARWOPNET, like other actors in this arena, tends to stress the propensity of mothers as 'natural' experts in the reintegration of child soldiers, not threatening the traditional patterns of gender dominance but capitalizing on an essentializing image of women as providers/caring mothers. A prominent member of AFELL stated that:

Women are ... a bedrock of any society whether educated or uneducated. ... The women artfully cross all lines of the various warring factions in search of food, water and medical services for their families as well as others who could not make it, and to earn an income to support the families. ... In war torn societies and out of war torn societies, it is the women who keep the society going...

At another conference in 2006, it was stressed that 'the challenge that we must face is to realise that women in other parts of the world happen to be far ahead from where we are ${ }^{46}$ In the words of a prominent activist:

... for us, the task is far from over. This is only the beginning..... The women's movement must continue to be the watchdogs for the government and must continue to work towards the attainment of gender equality and women's empowerment at all levels and all areas ... and strategise on how to promote women's leadership in postconflict peacebuilding in Liberia....

43 M.H. Moran, Civilized Women: Gender and prestige in Southeastern Liberia (Cornell University Press, Ithaka, NY, 1990).

44 Interview at the Ministry of Gender and Development, Monrovia, March 2007.

45 Varbah Gayflor quoted in: European Commission and Konrad Adenauer Foundation, Gender Awareness and Gender Equity in Liberia. The Gbarnga Conference 2005 (European Commission/Konrad Adenauer Foundation, Monrovia, 2005).

46 This and the following quote are from WANET and WIPNET, Women's National Agenda for Peace, Security and Development, adopted 30 March 2006 (Women in Peace Network, Monrovia, 2006). 


\section{Support from international agencies}

Studies of women's movements have often omitted the role of foreign actors, notably multilateral and bilateral aid and peace-building agencies. Reports on Liberia's 'women in peace' movement have usually stressed the indigenous agency of Liberian women. While I do not wish to diminish the important role and intrinsic motivation of the committed women who have participated in the movement, the possibility that without external support the women might not have been mobilized to such an extent should not be overlooked. Since the civil conflict, international support for women's organizations has gained momentum, particularly in those parts of Liberia that have constituted the major catchment areas of national and international aid, namely the urban centres and the counties or districts that are relatively easy to access by road from the capital. The peace movement was reportedly initiated in 1994 by a group of women who had been trained extensively in peace-building processes by international NGOs. A UN organization facilitated the participation of a comprehensive delegation of Liberian women at the Fourth Women's World Conference in Beijing in 1994, with this international experience working as a trigger in the unfolding of the Liberian women's movement. The endeavours of AFELL and other female activists in the field of legislation concerning women's rights have been supported by international consultants, organizations in the US and the UN Human Rights Office in Liberia. MARWOPNET's foundation was supported by the international NGO Femmes Africa Solidarité. Multilateral agencies have continued engaging women's organizations in demobilization, disarmament, reconstruction and rehabilitation programmes, and in the civic education projects preceding the 2005 national elections.

International agencies have provided, on the one hand, symbolic and material resources for the movement and, on the other, fora of communication which are essential to any kind of social movement. The most pertinent social spaces in the women's movement have been the leagues of conferences and workshops supported by the UN offices in charge of gender affairs in Liberia and international NGOs. Many of the recent policies pursued by the UN resonate with the measures proposed by Hunt and Posa within a policy framework of 'inclusive security'. ${ }^{47}$ The so-called international community has been a particularly forceful factor and seems to dictate the direction that the movement is taking.

As elsewhere, the peace-building policies of the international community in Liberia include efforts at restructuring social relationships. International actors have been heavily engaged not only in areas of practical need - an estimated

47 Hunt \& Posa, 'Women waging peace'. 
180 foreign charities are said to be active in Liberia today ${ }^{48}$ - but also in gender mainstreaming activities either directly or indirectly by sponsoring local NGOs. Concepts of gender equality and women's human rights have been transferred to Liberia from a variety of external sources. In recent years, UNIFEM, the United Nations Development Programme (UNDP) and other international agencies have provided funding for projects to integrate gender concerns into the government's national reconstruction and peace-building programmes. Aid is often only meted out to so-called 'community-based organizations' that can prove they have support from 50 per cent of the female representation in their leadership. Male and female staff in local NGOs employed by UN agencies or international NGOs have been exposed to gender mainstreaming workshops. Male and female Liberians have been trained as facilitators in peace-building, usually in other African countries (but sometimes in Europe) since the beginning of the 1990s. Such courses invariably involve gender issues, in particular the topics of leadership and gender-based violence, the concomitant discourse that contributes to polarizing the roles of perpetrator and victim according to gender. Members of local women's organizations, including those from rural communities, have been trained in the subject matter by different NGOs. Civiceducation projects funded by international agencies have emphasized women's potential for leadership, ${ }^{49}$ and workshops have been backed up by corresponding messages in media broadcasts with regional or nationwide coverage, in particular by UNMIL Radio and county-based radio stations sponsored by international organizations. With external support, WIPNET, for example, has run a Voices of Women radio programme in three counties for a number of years and the messages put across are reinforced by interactive theatre performances in some regions. Slogans and songs about gender equality and women's empowerment seem to be activated, often teasingly, as a kind of 'folk' wisdom in semiurban contexts even in the country's interior. Not surprisingly since the election of the female president, gender issues have become an even more pervasive topic in the media, and various government affirmative action programmes are targeting girls and women directly. WIPNET, supported by UNDP, continues to be very involved, moving from women in peace building and women in leadership to civic education on women's human rights.

US-based agencies in particular support the strategic needs of Liberian women and President Johnson Sirleaf even received an award from the National Democratic Institute (NDI) for her work in promoting democracy in Liberia.

48 'Liberia. With a little help from her friends', The Economist, 23 August 2008, p. 34.

49 For example, in November 2007, a programme was launched by UNDP and the MGD to conduct leadership training for 300 women leaders in all counties; 'Liberia: LIPA, Gender Ministry Sign Agreement', The Inquirer (Monrovia), 6 November 2007. 
The encouragement of gender equality has been linked discursively to the 'building of democratic strength in your nation for years to come' by the Speaker of the US House of Representatives. ${ }^{50}$ Liberian women have reportedly participated in training programmes run by the Women and Politics Institute at the American University to learn the tricks of the trade from top political leaders. However Liberia's women do not need to leave their home country to receive training. For example, the NDI and Women's Campaign International train women in how to become more politically empowered in their own countries. ${ }^{51}$ Women in rural Liberia are being encouraged to actively fight for their rights with support from the National Endowment for Democracy, an American organization, in a project that seeks to strengthen the advocacy capacity of rural women and sensitize them in their participation in local and national politics. ${ }^{52}$ The UN mission in Liberia, UNMIL, is working closely with the Women's NGO Secretariat, the MGD and AFELL to disseminate the laws and policies for the protection and promotion of women and girls' rights in the country.

\section{Constraints and divisions}

As with any type of collective identity, gender identities do not constitute stable entities. They are flexible, subject to intra-group variation and intersect with ethnic, religious, class and other shared identities. Depending on the context, any one of these differences may be attenuated by groups or individuals. ${ }^{53}$ In war-affected societies one may want to distinguish women analytically according to their differential access to economic resources, information, wealth and status, old from young women, women in remote rural areas and women in urban centres, but also according to new or recently emphasized roles (combatants, women who did not take up arms, 'bush wives', refugees, internally displaced people etc.), widows from married women, women intent on lasting change in gender relations and those who want to return to what they perceive as the stability of their pre-war arrangements. To complicate matters, the relative values and importance of those identities may be relevant only at certain stages in any woman's life. In addition to the ethnic, religious and class divides, the unity within the women's movement is jeopardized by yet further lines of

50 Courtney Hess, Washington, DC, 'West Africa: U.S. group honors women leaders' (www.allAfrica.com, October 27, 2007).

51 Nancy Bocskor, 'The changing global face of politics: training tomorrow's female leaders'. Women's Democracy Network

(http://www.wdn.org/Newscenter/Detail.aspx?ID=6, January, 2007).

52 See, for example, 'Rural women fighting for their rights' (www.allAfrica.com, June 16, 2008).

53 Henrietta Moore, 'The differences within and the differences between', in T. del Valle (ed.), Gendered Anthropology (Routledge, London, 1993), pp. 193-219. 
division. As Hebert ${ }^{54}$ has argued, feminist scholars have usefully offered explanations as to why women's social movements emerge but rarely have they explored why the goals of these movements remain out of reach. Many theorists acknowledge that the formation and functioning of social movements inevitably entail exclusionary practices concerning the collective identity that is identified as underlying these movements. Hebert has demonstrated that multiple lines of inclusion and exclusion associated with women's movements have occurred most notably along lines of ethnicity/race, class and gender. In addition, she mentions competitiveness among movement activists. Anecdotal evidence does indeed attest to problems within the movement under consideration that are arising from conflicts among the leaders of the various organizations and from the fact that the women's movement is run by members of the social elite.

Questions are also emerging about the inclusive range of the movement. Women certainly do not benefit from the gender discourse and affirmative actions if they do not have access to workshops, do not listen to the radio and/or do not understand English and live in an area where there are few programmes in local languages. In the remote southeastern border towns or the northwest of the country, discourse on gender equality is perceived as being 'something of the city', as respondents in the distant villages in Lofa and Grand Gedeh counties put it.

Here I want to focus on the religious/civilized identity which also includes aspects of a class and urban-rural divide in Liberia. It appears to entail not only the exclusion of Muslim women, notwithstanding efforts like those mentioned above to involve them, at least symbolically, but also implies conflict with uneducated women, in particular those non-Christian 'native' women with a stake in Sande society. In a variety of contexts both Americo- and AfroLiberian women have been able to claim status as social seniors. In particular, the prestige of civilized status was enhanced by the Christian churches and their affiliated women's clubs and organizations that are open only to civilized women. ${ }^{55}$ Significantly, Americo-Liberian women, women raised by AmericoLiberian families or by Christian missionaries have been crucial functionaries in the movement. Since before the war, Christian NGOs have played a major role in educating girls and given women leadership positions in their organizations, for example in the Christian Health Association of Liberia. A report on the movement states:

54 Laura Hebert, 'Women's social movements, territorialism and gender transformation: A case study of South Africa', Paper presented at the annual meeting of the American Political Science Association, Marriott Wardman Park, Omni Shoreham, Washington Hilton, Washington, DC, 1 September 2005

(http://www.allacademic.com/meta/p41242 index.html, September 5, 2008).

55 Moran, The Violence of Democracy, p. 83. 
... religious beliefs, reflected in extremely high levels of affiliation to churches and mosques, are the foundation of many Liberian women's commitments to peacemaking and their conviction that peace must start with the individual. As threats to survival grew and the need for personal peace intensified, non-traditional spiritual movements [emphasis mine, VF] became stronger and were often led by powerful women whose followers crossed ethnic and class lines. That these leaders were 'persons of God, who can be trusted' was an additional basis for solidarity among women. $^{56}$

Women were particularly mobilized in the cities and funds were raised by establishing or employing international connections. (More than ever today, literacy is a crucial leadership skill, even in the rural areas. The leaders of the new Muslim women's organizations are literate because they have attended government schools in addition to their Qur'anic education.) Although rural and uneducated urban women have been impressively active members of the peace movement, there appear to have been serious 'class' divisions among them. In a sense the social and cultural capital that the movement was been built on and the religious identity of the majority of activists are harbouring seeds of dissention.

Since 1994 when educated women activists founded the network, there has reportedly been major conflict between the uneducated/'country' and educated/ 'Congo' women. It would seem that the uneducated have to some extent been instrumentalized by their leaders. It was not the elite women who were reported to have been seen 'sitting on the airfield', in other words performing the tedious task of daily peace demonstrations and praying in the rain and sun for hours, but rather 'the common women' in their white T-shirts. Educated members of the movement may also indirectly associate being 'civilized' with claims of being 'emancipated' or 'empowered'. 'We have seen the light' is one of many religious idioms used to express a new feminist consciousness in public discourse. What may be called a maternalistic attitude is surfacing concerning the agency of change, which is reminiscent of the historical commitment to the old 'civilizing mission' as an important dimension of the settlers' identity. In public contexts, 'civilized' activists may emphasize the necessity to 'lift up' their uneducated sisters who 'are still in darkness'. Rural women are construed to be in dire need of education and sensitization about 'their' women's rights in order to be delivered from male suppression. Christian women tend to stress their religiosity and perform as respectable members of society (perhaps to neutralize fears of the conservative men in power). The support of church leaders is being sought to build legitimacy. WIPNET women, after their march through the city

56 African Women and Peace Support Group, Liberian Women Peacemakers, pp. 3435. There may be a connection between the movement and the mushrooming of Pentecostal churches in the wake of the war. 
of Monrovia following their May 2006 conference, presented a peace torch to the President of Liberia, announcing that it had previously been blessed by the Catholic Church's archbishop. Even though WIPNET has made special efforts to be inclusive as a network, the traditional Christian-Muslim divide is maintained in practice for political expediency.

Many, if not all, leaders have capitalized on the training they have received in workshops and on the cultural and social capital they have gained as participants at international conferences. Women qualified in this way constitute a small minority of the well-educated who have become the coveted experts, trainers and managers employed by the international agencies that are constantly in search of female project partners (for reasons of political correctness). A decline in commitment to the women's collective cause has been observed among the elite women who are said to have found new pastures in government or in positions with international agencies. This appears to have weakened the movement. This process of concentration may even have reinforced class distinctions within the movement.

It should be mentioned that, ironically, the policies related to the law on rape whereby an increasing number of rape cases have been taken to court (albeit with dubious outcomes) throughout the country in the last two years and the ensuing debates may turn out to be a possible divider. First, women disagree about the reason for the increase in rape cases. The young urban women may be blamed by more traditionally minded female elders for their provocative ways of dressing and lack of morals. Secondly, women's concepts of female personhood differ. In the traditional rural context, rape tends to be perceived as a violation of property (of the family or the husband), which is shameful in principle and is therefore glossed over, particularly if the perpetrator is a relative. Or it is treated as a family affair, involving indemnification fees to the family concerned. Such practices do not match the conceptions of urban female humanrights activists who put the physical and psychological damage of the victim centre stage. Ideological debates about this issue can be heard even in the country's remotest villages.

Unwittingly, the international community seems to be contributing to divisions in the movement in yet another direction. The centralized organization of Sande society, which, like the Poro, had been courted and to some degree incorporated in Liberian government since the time of President Tubman, ${ }^{57}$ served to organize self-help activities (meeting 'practical needs') for thousands of Li-

57 S. Ellis, 'The mutual assimilation of elites: The development of secret societies in twentieth-century Liberian politics', paper presented at the conference 'The Powerful Presence of the Past' (Halle/Saale, Max Planck Institute for Social Anthropology, October 2006). 
berian women during the war. ${ }^{58}$ The society was mobilized to join the peace marches but in a wider societal context, the Sande appears to have suffered a crisis of legitimacy in the wake of the war. Its activities were disrupted in many regions and a significant group of women in Liberia's north and west no longer consider membership of the Sande as being important in their lives (like men with respect to the Poro). In this domain, Liberian society has become divided down to the family level. Many urban girls - and the great majority of the urban population is female ${ }^{59}$ - would not consider being initiated. Mothers refuse to send their daughters to the 'Sande bush' (often opposing the wishes of elder rural kin). Before the war such challenges were only heard of in the context of isolated incidents of Christian fundamentalism in missionary contexts. ${ }^{60}$

The fact that traditional institutions, in particular the Sande and Poro societies, have been weakened or even dissolved is discursively linked by elders, both male and female, to the perceived lack of respect and loss of discipline in young women, especially in the urban areas of the interior. ('The war has turned their minds.') Elders and leaders returning from exile have lobbied for the revival of initiations camps (bush schools) and praised the virtues of the secret societies regarding their (purported) regulatory and stabilizing functions but this spiritual vocation may of course be linked with the motivation of generating income from initiates' families. In many parts of the northwest, the secret societies are reported to have resumed their activities, sometimes with external support from NGOs in a (perhaps misconceived) effort to promote indigenous authorities that are assumed to hold legitimate offices in conflict regulation. It is worth mentioning that the re-legitimization of the Sande in Liberian society has been fostered by the current president, Ellen Johnson-Sirleaf, who courted the Sande network as one of her constituencies in the run-up to the elections in 2005. In this context, it is significant that one of the outcomes of a women's conference in May 2008 has been an appeal to the donor community to support the Ministry of Education and to schools and community leaders 'to develop innovative strategies ... to harmonize traditional and academic schools schedules to encourage girls (sic) retention in schools'. ${ }^{61}$ This indicates that 'bush

58 Interview with Mama Tumah Sieh, Executive Director for Women Affairs of the Ministry of Internal Affairs for twenty-five years and national representative of the Sande society (also in the Truth and Reconciliation Committee) in her 'village' near Monrovia, March 2007.

59 Government of Liberia, 2008 National Population and Housing Census: Preliminary results (Liberia Institute of Statistics and Geo-Information Services (LISGIS), Monrovia, 2008).

60 Ellis, 'The mutual assimilation of elites'.

61 Ministry of Gender and Development and United Nations, National Women's Conference Report. 
school' sessions have been resumed on a large scale because, as before the war, the sessions compete with the annual cycle of schooling times and parents often take their children out of school to have them initiated.

As an example of disjointed measures of donor support, other NGOs have tried to raise awareness about the damage caused by female genital mutilation (FGM) which is an integral part of initiation into the Sande. Apparently under pressure from the international community, the Ministry of Internal Affairs is working towards banning the practice but Sande leaders reportedly walk out of meetings whenever the issue of FGM is raised; considering it outrageous to discuss it with men or non-members. The oath they took obliges them to keep secret the circumstances surrounding the circumcision ritual and it prevents them from discussing the topic with non-members. Even though some Sande leaders are said to be very aware of the consequences of FGM, they cannot apparently stop the practice. They fear the punishment that will befall them if they do not fulfil their duty, as the penalty expected from the spirits is death, disgrace or life-long suffering. I cannot even begin to judge whether this is their personal/social 'truth' or whether it is a spiritual discourse employed to defend the order that privileges them. For the women's movement, it is politically expedient to embrace the Sande leaders as representatives of both traditional leaders and rural women at any public performance, such as a conference. Backstage, however, 'enlightened' (urban) women leaders are very critical of the revitalization of 'bush schools': they reject the transmission of traditionally submissive female roles and the practice of FGM.

\section{Moving where? Conclusion and prospects}

African women's participation in national politics has often been based in women's movements, even in the wake of civil conflict. ${ }^{62}$ Liberia's women's movement, which is clearly a child of the civil war, contributed significantly to the election of Ellen Johnson-Sirleaf, and the movement has certainly enhanced the self-confidence of many women. While educated women cultivate new identities as agents of change, peace makers and professional or political leaders, the movement also appears to have brought about non-adherent potential beneficiaries in many sectors. School girls and illiterate women struggling to survive in the fields, streets and markets have expressed pride in the achievements of visibly powerful women, particularly the president.

However, the women's movement in Liberia seems to be crumbling. It has never been a united network of heterogeneous groups of actors united to serve

62 Gretchen Bauer \& Hannah E. Britton, 'Women in African parliaments: A continental shift?' in G. Bauer et al. (eds), Women in African Parliaments (Lynne Rienner Publications, Boulder, Col., 2006), pp. 1-30. 
the cause of peace. Since 2003 the differences in interests among its members have become ever more important and, having been promoted by the international community since the early 1990 s, the movement appears to have turned into a branch of the peace-building and development business. Many of its leaders are using their skills to engage in politics, international trade and business, and/or they are acting as 'development brokers' on behalf of their communities.

The movement has been led by women from national and local social elites who have successfully mobilized a range of women's organizations for peace activism, and subsequently for individual political participation. International agencies have offered massive support to institutionalize women's human rights. The big Monrovia-based organizations are still riding on the ticket of 'inclusive security' as promoted by the international community, particularly in the context of activities surrounding the 'rape law' and the pending local elections. Another crucial strategic need has recently been addressed by AFELL and the UN: women's rights to land. Local organizations, however, continue to be concerned with practical needs, where possible using the movement's network to mobilize external funding.

The perceived benefits of the women's movement seem to be recognized by many Liberian men, albeit selectively. As a force promoting security, peace, moral communities and conflict regulation, the movement is considered as a common good. In public discourse, the fact taken for granted in pre-war Liberian society that women were the sole providers for their families is generating more explicit respect today. Women's new opportunities for access to international resources are welcomed as assets for households, families and their communities. However, the emergence of new public domains of female activities, women's rights and women's direct competition for political resources is disconcerting for male asset-holders. The women's movement has also provided symbolic resources for girls and women striving to escape the control of their social seniors. In the cities, they are following well-established pre-war strategies of multiple partnerships, ${ }^{63}$ and novel gender discourses are adding a new dimension to conflicts with the authority of the elders. They refuse to be told what to do by rhetorically referring to their rights. (To what extent this development is related to the observed dramatic increase in domestic violence is an issue still to be investigated.)

The movement's future continuity will depend on coherence between institutional reform, practical experience and the narratives and ideologies in place.

63 V. Fuest, 'A Job, a Shop, and Loving Business'. Lebensweisen gebildeter Frauen in Liberia (LIT Verlag, Münster, 1996); Olonisakin, 'Women and the Liberian Civil war'. 
The efforts of committed women activists and affirmative action, represented by the Liberian president as well as the policies, resources and discourses offered by the international community and US-based organizations in particular, will contribute to upholding the women's movement. 


\title{
Nurtured from the pulpit: The emergence and growth of Malawi's democracy movement
}

\author{
Boniface Dulani
}

\begin{abstract}
Most accounts of the wave of democratization that swept across the African continent in the early to mid-1990s point to the pivotal role played by movements that successfully forced authoritarian regimes to embrace democracy. But how did these movements emerge in an environment where the political space was closed or severely limited? Drawing on Malawi's transition from authoritarian to democratic rule in the early 1990s, this chapter discusses how democracy movements in Africa came about through a process of regime rupturing after the intervention of exogenous actors in the political arena. In the case of Malawi, the Catholic Church was such an actor when, in 1992, it intervened in the political arena by issuing a highly critical pastoral letter that challenged the legitimacy of the thirty-year dictatorship of the then president-for-life, Hastings Kamuzu Banda.
\end{abstract}

\section{Social movements and the democratization process in Africa}

The history of post-independence African politics can be divided into two periods. The first, coming immediately after independence, was dominated by authoritarian forms of government that ranged from military to civilian dictatorships while the second is the era of democratization that started in the last decade of the twentieth century.

During the authoritarian era, African leaders devoted a great deal of energy to suppressing political dissent at both group and individual levels. Political parties were often completely outlawed, which was common practice in military 
dictatorships, and opposition parties were banned in one-party states. ${ }^{1}$ Individuals who expressed even the mildest forms of dissent were imprisoned, frequently without trial. Some were assassinated or murdered by state security agents while the (few) lucky ones managed to escape and live in exile. In other instances, the business interests of individuals who were perceived to hold critical views were frustrated, in some cases, being expropriated by the state. ${ }^{2}$

The disbursement of patronage to supporters and opponents of the regime served as another instrument for the ruling elites to entrench power. As Medard notes, 'through patronage, the leaders [were able to] co-opt potential opponents and regulate the recruitment of the ruling class'. ${ }^{3}$ Patronage networks thus served to undercut civil society by blocking opportunities for the emergence of strong and well-organized pro-democracy groups. Popular associations and organized groups, such as trade unions, that were considered to be hotbeds of dissent and to pose a potential challenge to the ruling elites were subsequently eradicated or emasculated. The only civic structures that were spared during the authoritarian era were those headed by hand-picked loyalists and that therefore posed no significant threat to the ruling elite As a result, political opposition was either wholly undermined and/or so weakened that the continent's authoritarian rulers were able to enjoy long years of unchallenged authority. Notable African leaders in this category include Malawi's Hastings Banda, Ivory Coast's Felix Houphouët-Boigny, Omar Bongo of Gabon, Paul Biya of Cameroon, Kenneth Kaunda in Zambia, Daniel arap Moi in Kenya and Robert Mugabe in Zimbabwe, to name but a few.

By its very nature, authoritarian rule created a lot of losers. Individuals who fell foul of the regime were either sent to prison, went into exile or were allowed to operate but in a severely restricted environment. These groups, together with other sympathizers, served as a latent opposition even if they faced significant obstacles to organizing and operating publicly.

The 1990s marked a new era in African politics that was characterized by the introduction of democratic politics. Between 1990 and 1993 for example, 27 of the continent's 53 countries made the transition from a one-party system or a military dictatorship to a multi-party democratic system. By 1994, single-party

1 See R. Jackson \& C. Rosberg, Personal Rule in Black Africa: Prince, autocrat, prophet and tyrant (University of California Press, Berkeley, CA, 1982).

2 B. Muluzi, Y. Juwayeyi, M. Makhambera \& D. Phiri, Democracy with a Price: The history of Malawi since 1900 (Jhango Heinemann, Blantyre, 1999).

3 J-F. Medard, 'The underdeveloped state in tropical Africa: Political clientelism or neo-patrimonialism?', in C. Clapham (ed), Private Patronage and Public Power: Political clientelism in the modern state (Frances Pinter, London, 1982), p. 167. 
authoritarianism had been formally abolished and replaced by multi-party democracy throughout almost the entire Sub-Saharan African region. ${ }^{4}$

The democratic transitions of the 1990 s were, in most cases, contested events. On the one hand, the long-serving political elites resisted the introduction of democratic politics and used a variety of strategies to suppress any challenge to their hold on power. On the other hand however, there were the democracy movements - loose coalitions of groups that were united in their opposition to authoritarian rule - that emerged to play a decisive role in forcing the continent's numerous authoritarian regimes to democratize. ${ }^{5}$

As a social force, Africa's democracy movements were coalitions of groups united in their shared antipathy towards authoritarianism. They included women's movements, trade unions, university student groups, farmers' associations, university staff, civil servants, political exiles, underground opposition groups, business and lawyers' associations and other professional groups. ${ }^{6}$ While the interests and backgrounds of these groups differed, they had a common denominator in seeking democratic change.

The potency of the democracy movements across Africa in forcing a transition to democratic forms of governance is demonstrated by Bratton and Van de Walle, who point out that out of the 21 cases of democratic transition that took place between November 1989 and 1991, sixteen (representing 76\% of the total) were initiated by pro-democracy protest groups. ${ }^{7}$ The critical role played

4 M. Bratton \& N. van de Walle, Democratic Experiments in Africa: Regime transitions in comparative perspective (Cambridge University Press, Cambridge, 1997).

5 D. McAdam, J. McCarthy \& M. Zald, Comparative Perspectives on Social Movements (Cambridge University Press, Cambridge, 1996); D. McAdam, S. Tarrow \& C. Tilly, Dynamics of Contention (Cambridge University Press, Cambridge, 2001); L. Diamond, 'Beyond autocracy: Prospects for democracy in Africa', in Working Papers for the Inaugural Seminar of the Governance in Africa Program (The Carter Centre of Emory University, Atlanta, GA, 1989); K. Mengisteab \& C. Daddieh, State Building and Democratization in Africa: Faith, hope, and realities (Praeger, London, 1999); Earl Conteh-Morgan, Democratization in Africa: The theory and dynamics of political transitions (Praeger, London, 1997); G. Nzogola-Ntalaja, 'Citizenship, political violence and democratization in Africa', Global Governance, 10 (2004), pp. 403-409; R. Joseph, State, Conflict and Democracy in Africa (Praeger, London, 1999); R. Press, Peaceful Resistance: Advancing human rights and democratic freedoms (Ashgate, Aldershot, 2006); A. Ngoma-Leslie, Social Movements and Democracy in Africa (Routledge, New York, 2006).

6 Ngoma-Leslie, Social Movements and Democracy in Africa; Press, Peaceful Resistance; Bratton and Van de Walle, Democratic Experiments.

7 M. Bratton \& N. van de Walle, 'Neopatrimonial regimes and political transitions in Africa', MSU Working Papers on Political Reform in Africa, Working Paper No. 1 (Department of Political Science East Lansing: MI, 1993); See also Press, Peaceful Resistance. 
by the democracy movements in forcing regime change in Africa suggests that the wave of democratization in Africa in the 1990s was a bottom-up process that was forced upon reluctant elites by social movements united in their demands for political change.

This bottom-up process of democratization challenges some of the leading theories that try to explain how regime change occurs and how social movements emerge. With regards to the literature on regime change, studies of democratization in Latin America and Eastern Europe have tended to emphasize the role of the ruling elites in initiating the process of change. In their groundbreaking work on democratic transition in the Americas, O'Donnell and Schmitter argued that regime change occurs through a process of elite fracturing. They went on to assert that 'there is no transition whose beginning is not the consequence - direct or indirect - of important divisions within the authoritarian regime itself'. ${ }^{8}$ The African cases, however, fail to fit into this 'elite fracturing' model of democratization. Instead, the social-movement-driven process suggested a process of system rupturing from below, with the elites being compelled to introduce institutional change without any internal divisions.

Meanwhile the literature on social movements tends to locate their emergence within the framework of political opportunity structures, which emerge from institutional changes by the ruling elites that open up the political space to other actors. McAdam, for instance, argues that the emergence of widespread protest activities is the result of 'a combination of expanding opportunities and indigenous organization, as mediated through a process of collective organization'. ${ }^{9}$ This position is shared by Tarrow who contends that opportunities for collective action against contentious politics emerge 'when institutional access opens, rifts appear within elites, allies become available and state capacity for repression declines'. ${ }^{10}$ In more recent work, Ngoma-Leslie also embraces this institutional perspective, arguing that the emergence of the women's movement

8 G. O'Donnell, Ph. Schmitter \& L. Whitehead (eds), Transitions from Authoritarian Rule: Tentative conclusions about uncertain democracies (John Hopkins University Press, Baltimore, 1986), p. 19.

9 D. McAdam, Political Process and the Development of Black Insurgency, 19301970 (University of Chicago Press, Chicago, 1982), p. 20; see also P. Eisinger, 'The conditions of protest behavior in American cities', American Political Science Review, 67 (1973), pp. 11-28; McAdam, Political Process and the Development of Black Insurgency; C. Tilly, From Mobilization to Revolution (Addison-Wesley, Reading, 1978); J. Gusfield, Protest, Reform and Revolt: A reader in social movements (John Wiley, New York, 1970).

10 S. Tarrow, Power in Movement: Social movements and contentious politics (Cambridge University Press, Cambridge, 1998), p. 71. 
in Botswana politics was 'dependent on the receptivity of the political process'. ${ }^{11}$

While structural accounts offer a powerful framework for understanding the rise of democracy movements, they do not give sufficient information as to why the ruling elites would consent to introducing those structural changes in the first place, especially since they undermine their ability to remain in power. It is precisely because those who are entrusted with the responsibility to initiate any institutional changes are also often those with the most to lose that the North contends that, once created, institutions become sticky and only change incrementally. ${ }^{12}$ The introduction of the institutional changes that enabled democratic movements to emerge and effectively challenge authoritarian regimes in Africa poses a major puzzle that I seek to address in this chapter. Why would authoritarian regimes make changes that create opportunities for the emergence of organized movements that threaten their own political survival? The discussion that follows attempts to unravel this by examining the emergence of the democracy movement in Malawi and the role played by the Catholic Church there in the process. I demonstrate that the origins of the democracy movements lay not in a process of wilful concessions by the ruling elites but instead were a result of the rupturing of the state apparatus that happened after the intervention of an exogenous actor in the political arena. In the case of Malawi, the rupturing resulted from a pivotal decision by the Catholic Church's hierarchy to intervene in the political arena by challenging the legitimacy of the one-party authoritarian regime in a way that served as a catalyst for the emergence of a democracy movement that subsequently went on to force the authoritarian regime to accept the introduction of institutional changes that led to the introduction of democracy.

\section{'Living our Faith' and the birth of the democracy movement in Malawi}

The period between Malawi's independence in 1964 and 1992 was characterized by tight control of the political space by the ruling elites. Under the 1966 Constitution, the Malawi Congress Party (MCP) was designated as Malawi's only legal political party, thus closing off any avenues for organized political opposition. The designation of Malawi as a constitutional one-party state was followed by a constitutional amendment in 1971 that conferred the status of President for Life on President Hastings Banda.

11 Ngoma-Leslie, Social Movements and Democracy in Africa, p. 29.

12 D. North, Institutions, Institutional Change and Economic Performance (Cambridge University Press, New York, 1990). 
In the ensuing years, Banda embarked on a systematic and sustained process of consolidation of his hold on power by ruthlessly suppressing opposition voices. Membership of the MCP was made compulsory and was enforced by the party machinery. Meanwhile, the state's coercive institutions, the army and the police were frequently used to silence critical voices, detaining, torturing and sometimes even murdering individuals thought to hold anti-government views. Sindima, for example, captures the extent to which the Banda regime dealt with any opposition when he pointed out that:

those who crossed paths with Dr. Banda and his MCP ... suffered untold physical and emotional pain inflicted on them and their family members ... a good number of political detainees spent many years in prison ... and some were never again heard of after they had been picked by the [Police] Special Branch or the Malawi Young Pioneers. ${ }^{13}$

In addition to the harsh treatment that was meted out on critics, the Banda regime had tight control of the media as part of its broader strategy of ensuring that the public would only have access to government-controlled propaganda. Private media sources were banned, while the censorship board became very active in restricting access to publications perceived as having contaminating political content. Meanwhile the trade unions, which had supported the Bandaled nationalist movement in the struggle for independence, were either legislated out of existence or brought under MCP control. Within six months of gaining independence, fourteen trade unions had been deregistered and all the civil-service unions were banned. At the same time, a number of the more firebrand union leaders were co-opted and offered positions in government. ${ }^{14}$

It was within this tightly controlled political space that the country's Catholic bishops issued their historic pastoral letter entitled 'Living Our Faith' ${ }^{15}$ on 8 March 1992. Although ostensibly addressed to the Catholic faithful, the pastoral letter clearly targeted a wider audience and was written in a language designed to provoke public action for political change. A total of 16,000 copies of the letter were distributed nationwide. In a bid to reach the largest possible audience, 10,000 were printed in Malawi's national language, Chichewa, which is spoken by more than $65 \%$ of the country's population, a further 5,000 were

13 H. Sindima, Malawi's First Republic: An economic and political analysis (University Press of America, New York, 2002). See also J. Lwanda, Kamuzu Banda of Malawi: A study in promise, power, and paralysis (Dudu Nsomba Publications, Glasgow, 1993); Muluzi et al., Democracy with a Price.

14 See L. Dzimbiri, 'The State and Labour Control in Malawi: Continuities and discontinuities between one-party and multiparty Systems', Africa Development, XXX, 4 (2005), pp. 53-85.

15 Episcopal Conference of Malawi (ECM), Living our Faith: Lenten letter of the Catholic bishops to their faithful (Montfort Media, Balaka, 1992). 
printed in Tumbuka which is the main language spoken in northern Malawi, and the other thousand copies were printed in English. The pastoral letter was read out in all the Catholic churches across the country, with members being encouraged to get copies for discussion in their communities and villages. ${ }^{16}$ All this combined to ensure that the message of political change advocated in the letter reached a significant proportion of the country's citizens.

Through references to Biblical texts and a language of freedom and justice, 'Living our Faith' identified some of the key weaknesses and failings of oneparty, one-man rule. Specifically addressing what were considered the key socio-economic and political failings of authoritarian rule, the letter highlighted Malawi's need to move beyond one-man rule by making allusions to traditional proverbs that emphasized the benefits of shared leadership:

[The strength] of African society ... resides in recognizing the gifts of all and in allowing these gifts to flourish and be used for the building of the community. 'Mutu umodzi susenza denga' - no one person can claim to have monopoly of truth and wisdom. No individual - or group of individuals - can pretend to have all the resources needed to guarantee the progress of a nation ... the contribution of the most humble members is often necessary for the good running of a group. ${ }^{17}$

It is noteworthy that the pastoral letter's language did not portray the bishops or the Church as the agents of change. Instead, 'Living our Faith' was framed as a call for action, requiring Malawians to rise up and 'respond to this state of affairs and work towards a change of climate ... participation in the life of the country is not only a right; it is also a duty that each Christian should be proud of'. ${ }^{18}$ 'Living our Faith' was a critique of authoritarian rule and a call for the emergence of a democracy movement to challenge the status quo.

Suffice to say, 'Living our Faith' marked the first time that the Banda regime had faced a domestic challenge of any magnitude. The atmosphere of fearful and silent acquiescence that had limited Malawian political discourse for three decades had been challenged, not by a small circle of activists and political exiles but from the pulpits in churches in every district in the country. 'Living our Faith' was subsequently seen as an invitation for bottom-up mobilization for regime change. In the words of Chirwa et al., the pastoral letter:

... served as ferment, challenging various groups, especially the workers to organize and go on strike ... while at the same time, the exiled opposition felt emboldened

16 P. O’Maille, Living Dangerously: A memoir of political change in Malawi (Dudu Nsomba, Glasgow, 1999).

17 ECM, Living our Faith, p. 3.

18 Ibid., p. 6. 
and saw the Letter as offering much needed moral support for their agitation for political change. ${ }^{19}$

The 1992 pastoral letter almost instantaneously emboldened the anti-authoritarian movement in Malawi. As Lwanda puts it, 'Living our Faith' served as 'a spark that ignited Malawi's democracy revolution'. ${ }^{20}$ The letter's ability to elicit such public response was due in large part to the fact that its overall message of change touched on issues that most of the public identified with and had longed for someone to voice. Within a week, students from the University of Malawi issued their own letter of solidarity, observing that the bishops had become the 'mouthpiece for the voiceless and powerless ... [and that] the people of Malawi needed more than just political freedom at independence, they also needed a social and economic emancipation'. ${ }^{21}$ This was followed by a march by university students to the residence of the Catholic Bishop of Zomba Diocese to demonstrate their solidarity. When the government responded to this demonstration by closing Chancellor College campus in Zomba, students from two other constituent colleges of the University of Malawi in Blantyre and Lilongwe staged their own street demonstrations in support of the bishops and their fellow students and called for the introduction of democracy. ${ }^{22}$

Other leading churches also weighed in embracing the message of 'Living our Faith' and echoing calls for urgent political reform. Among the churches that supported the Catholic prelates were the Church of Central Africa Presbyterian (CCAP) Blantyre and Livingstonia Synods, which issued their own statement on 4 June 1992 reiterating calls for social, political and judicial reform. $^{23}$ The decision by these two CCAP synods to show solidarity with the Catholic Church and the pro-democracy movement magnified the potency of

19 W. Chirwa, N. Patel \& F. Kanyongolo, 'Malawi: Democracy factfile' (Research report to the Southern African Research and Documentation Centre, SARDC, mimeo, 1998), p. 2; see also L. Mitchell, 'Living our Faith: The Lenten letter of the bishops of Malawi and the shift to multi party democracy, 1992-1993', Journal for the Scientific Study of Religion, 41, 1 (2002), pp. 5-18; J. Newell, 'A moment of truth? The Church and political change in Malawi', Journal of Modern African Studies, 33, 2 (1995), pp. 243-262; M. Nzunda \& K. Ross, Church, Law and Political Transformation in Malawi, 1992-1994 (Mambo Press, Gweru, 1995).

20 J. Lwanda, Promises, Politics and Poverty: Democratic transition in Malawi (Dudu Nsomba Publications, Glasgow, 1996), p. 104.

21 University of Malawi Catholic Studies Association, letter of 13 March 1992.

22 O'Maille, Living Dangerously, offers a personal account of how university students and faculty embraced the pastoral letter and brought its contents to the attention of the international community.

23 Nkhoma Synod, one of the three CCAP synods, did not support this statement. Banda himself and some of the senior MCP members belonged to the Nkhoma Synod. 
the demands for political change because these church groups together accounted for more than half of Malawi's entire population.

For their part, private- and public-sector workers seized the opening created by the pastoral letter and staged a series of unprecedented wild-cat strikes that began in April 1992 and continued into the following year. ${ }^{24}$ As with the university students, the strikers referenced their actions on the Catholic bishops' calls for the equitable distribution of the benefits of development through improved wages and better working conditions. Elsewhere, democracy activists, who until then had been operating underground, emerged and formed pressure groups that began to campaign openly for the introduction of democracy. These included the United Democratic Front (UDF) that had been formed in October 1991 as an underground group of influential Malawians who were disillusioned with authoritarian rule. The extent to which the 1992 pastoral letter provided the opportunity for the UDF to surface was captured by one of the group's founding members, Aleke Banda, who pointed out that the pastoral letter 'was a source of great strength to the pressure group and probably brought forward its existence by at least ten years'. ${ }^{25}$

The immediate aftermath of 'Living our Faith' saw the creation of new civilsociety groups that aimed to promote and advance a democracy agenda. One of the most influential civil-society organizations to emerge during this period was the Public Affairs Committee (PAC), in September 1992, with its primary objective of taking a strategic lead in socio-political initiatives in the country. ${ }^{26}$ Operating as an umbrella organization for the nascent pro-democracy groups, PAC drew its membership from the major religious groups in Malawi including the Catholics, the CCAP, the Anglican Church, the Muslim Association of Malawi and the Christian Council of Malawi. Other members included the two leading political pressure groups, the UDF and the Alliance for Democracy (Aford), which was formed in Zambia by a group of Malawian political exiles and intellectuals at the end of March 1992. Influential professional groups, such as the Associated Chambers of Commerce and Industry and the Malawi Law Society, were also among PAC's founder members. Elsewhere, non-governmental organizations focusing on issues of governance began to emerge as key players in the democracy movement. Notable in this period were the Civil

24 K. College, Trade Unions and the Struggle for Quality Services in Malawi (PSI, Johannesburg, 2004).

25 T. Cullen, Malawi: A Turning Point (Pentland Press, Durham, 1994), p. 58.

26 K. Ross, 'The Transformation of Power in Malawi, 1992-94: The role of the Christian churches,' in K. Ross (ed.), God, People and Power in Malawi: Democratization in theological perspective (CLAIM, Blantyre, 1996). 
Liberties Committee (CILIC), the Human Rights Consultative Committee and the CCAP 'Church and Society' programmes, to mention but a few. ${ }^{27}$

In addition to rousing and energizing domestic opposition to one-party rule, 'Living our Faith' made another important contribution by bringing together for the first time domestic and exiled political opposition groups to work as one united front. Although the exiled opposition had long been in existence, it had failed to establish a domestic presence within Malawi, which had allowed Banda to dismiss it as an isolated group of disaffected individuals that had no domestic support. However the 1992 pastoral letter gave the opposition in exile a measure of credibility as well as a moral rallying point for regime change. ${ }^{28}$ Long years of political activism meant that they had the experience to give the fledgling democracy movement a big lift once domestic opposition surfaced. They brought with them new ideas for political organization that helped reshape and re-energize the democracy movement.

The extent to which the 1992 pastoral letter helped to galvanize the exiled opposition was demonstrated by the formation of Aford in Zambia towards the end of March 1992 by a group of Malawian exiles who were responding to the reformist message of 'Living our Faith'. Aford's objectives included campaigning for human rights and democracy in Malawi and the group chose Chakufwa Chihana, a former secretary-general of the Southern African Trade Union Coordinating Council, as its chairman. Capitalizing on the weakness of the one-party state that had resulted from the stinging criticism in 'Living our Faith', Chihana returned to Malawi on 6 April 1992 and immediately used the pastoral letter as the moral justification for political reform. ${ }^{29}$

The rupturing effect of the 1992 letter was further reflected in the emergence of a new and critical media. A total of sixteen newspapers were launched onto the market between March 1992 and early 1993, with the majority supporting the nascent democracy movement. Among the most vocal to emerge were the Malawi Democrat, Michiru Sun, the Monitor and the Nation. In addition to these new newspapers, pro-democracy groups used shortwave radio to broadcast messages from outside the country to the Malawian public via the South

27 W. Chirwa, 'Civil society in Malawi's democratic politics', in M. Ott, K. Phiri \& N. Patel (eds), Malawi's Second Democratic Elections: Process, problems and prospects (Kachere, Zomba, 2000).

28 See J. Chakanza, 'The pro-democracy movement in Malawi: The Catholic church's contribution', in Nzunda \& Ross (eds), Church, Law and Political Transition in Malawi, 1992-1994 (Mambo Press, Gweru, 1995).

29 K. Ross, 'The Transformation of power in Malawi'. 
African Broadcasting Corporation (SABC), the BBC and Voice of America. ${ }^{30}$ These new media forms offered Malawians a more critical perspective of their country's politics for the first time.

Although the Banda regime tried to fight a rearguard battle to discredit the Catholic hierarchy and the now resurgent democracy movement, it was unable to contain the mounting pressure for change that was being unleashed by 'Living our Faith'. The democracy movement continued to gather momentum and became increasingly independent of its religious origins. As a last act, the Banda government called for a referendum in June 1993 to decide whether Malawi should maintain the one-party system or adopt multi-party democracy. The mere fact that the authoritarian regime was forced to take this measure demonstrated that President Banda and the MCP no longer enjoyed the absolute power that had characterized Malawian politics for the previous three decades.

The democracy movement's ultimate victory came in June 1993 when the electorate voted by a margin of two to one in favour of multi-party democracy. Faced with this result, the government was finally forced to open up the political space by legalizing opposition party politics as well as relaxing the rules that had been used to silence dissenting voices. The 1993 referendum was followed by democratic elections on 20 May 1994. In a further repudiation of Banda, the UDF's Bakili Muluzi won a majority share of the presidential vote to become the country's first democratically elected president while his party scooped a majority of the seats in the new National Assembly. ${ }^{31}$ Within two years of the release of 'Living our Faith', Malawi had abandoned authoritarian rule and embraced democratic politics, sweeping the old guard out of power.

From the preceding discussion it is clear why the democratization process in Malawi can be considered a three-actor game. The first player, the authoritarian regime, employed strategies to maintain its hold on power. Through its historic intervention, the Catholic Church became the second major player in the game, challenging the authority and legitimacy of one-party rule in a way that created opportunities for the emergence of the democracy movement. Combined, the Church and the democracy movement were able to compel the ruling elites to open up the political space, which culminated in the 1993/1994 transition to democracy. The sequence is illustrated in Figure 1.

30 N. Patel, 'Media in Malawi's democratic transition', in M. Ott, K. Phiri \& N. Patel (eds), Malawi's Second Democratic Elections: Process, problems and prospects (Kachere Series, Zomba, 2000).

31 For a discussion of the 1994 election results, see L. Dzimbiri, 'Democracy and chameleon like leaders', in Kings Phiri et al. (eds), Democratisation in Malawi: A stocktaking (CLAIM, Blantyre, 1998). 
Figure 1 Model of the transition to democracy in Malawi

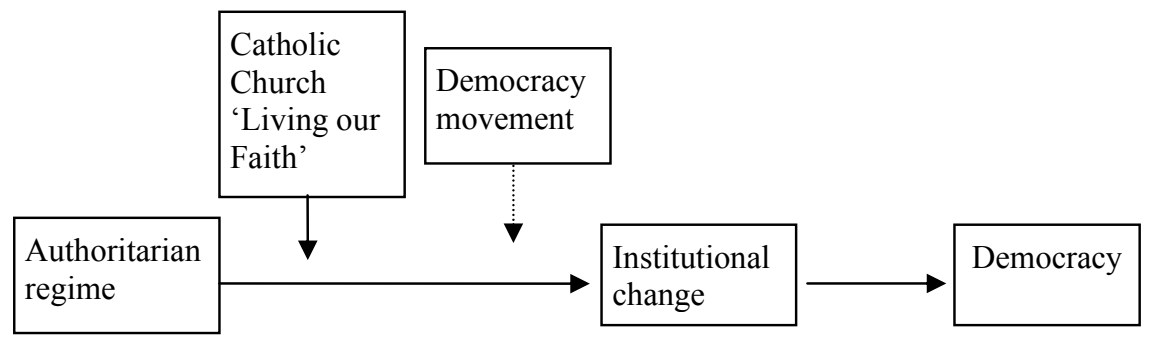

Without the Catholic Church's intervention, it would have been very difficult for the democracy movement to organize against Malawi's authoritarian regime. The Church's challenge to authoritarian rule played a critical role in preparing the way for the emergence of the democracy movement, which then pressurized the authoritarian regime to embark on a process of institutional change. This eventually led to the transition to democratic rule. Unlike the predictions in the literature that social movements are preceded by institutional change that leads to their creation, the Malawian case suggests that the process of institutional change only came about after the new democracy movement had already emerged.

\section{Beyond 'Living our Faith':}

The Catholic Church and the democracy movement after 1992

In addition to its pointed criticism of the legacy of authoritarian rule, a central message in the 1992 pastoral letter was self-admonition by the Catholic clergy of their silence during the thirty years of one-party rule. The bishops described this silence during Banda's dictatorial rule as 'a failure on the Church's spiritual mission as proponents of the common good and that ... it is no longer "pastoral" to sit back and pretend not to see problems in our society'. ${ }^{32}$ The Church's silence during one of Malawi's darkest political periods was, therefore, portrayed as a sign of acquiescence on the part of the Church to the dictatorship and human-rights abuses that characterized this time.

As well as offering a moral impetus for the emergence of the democracy movement, 'Living our Faith' signalled a new direction for the Catholic Church, shifting from an entity that focused exclusively on the spiritual realm to a new mission that sought an active role in the political arena. This new interventionist mission has been demonstrated by the issuance of pastoral letters that comment

32 ECM, Living our Faith, p. 2, 12. 
on current socio-political affairs. Between 1992 and 2008, Malawian prelates issued a total of eighteen pastoral letters, most of which offered some sort of political content. The most frequently recurring themes involved urging the Malawian public to exercise their right to vote, reducing corruption; advocacy for equitable development; information about the meaning of freedom and democracy; and criticism of anti-democratic traits in government.

To demonstrate that the Catholic Church's political engagement after 1992 had taken on a more permanent form, it established a number of bodies that would play an active role in the socio-political arena. These included the Catholic Commission for Justice and Peace (CCJP), which was established in the second half of 1992 to contribute 'to the common effort of the Episcopal conference and the whole Catholic Church ... in the creation of a just and peaceful Malawian society that promotes integral development and lasting peace ${ }^{33}$ With branches in every Catholic parish across the country, the CCJP provides the Catholic Church with a grassroots network that can be easily mobilized to promote democratic governance. The significance of this grassroots network was arguably best illustrated between 2001 and 2003 when the ruling UDF party attempted to remove the constitutional provision that limits any sitting president to serving a maximum of two five-year terms. While the Catholic bishops expressed their opposition to the proposal in their 2001 and 2002 pastoral letters, the CCJP took the matter further by taking the lead in a public debate against the proposal and claiming that it would 'bring Malawi back to the dark age of dictatorship'. ${ }^{34}$ As part of the campaign, the CCJP mobilized other pro-democracy actors under the common banner of the ChurchNGO Consortium that went on to run a series of public demonstrations and lobbied MPs to vote against the proposals. The sustained lobbying and public demonstrations eventually contributed to the defeat of the proposal when it came before Parliament in July $2002 .{ }^{35}$

The Malawi Catholic Church's quest to identify with the democracy movement was also demonstrated through the establishment of media 'houses' that offer a faith-based perspective on contemporary socio-political issues. These include three radio stations and a printing press that specializes in publishing newspapers, magazines, books and political literature. One of these is the

33 ECM, Walking Together in Faith, Hope and Love (Montfort Media, Balaka, 1999).

34 CCJP, 'Statement of the CCJP in Malawi and the third term debate', The Nation, 6 April 2002.

35 For a discussion of the third-term debates, see B. Dulani \& J. K. van Donge, 'A decade of legislature-executive squabble in Malawi (1994 - 2004)', in M. Salih (ed), African Parliaments: Between governments and governance (Palgrave Macmillan, London, 2005). 
Lamp,$^{36}$ a monthly magazine that publishes semi-academic articles on Malawi's democratic process, as well as pamphlets on themes such as 'building the country under democracy' and 'lessons on democracy. ${ }^{37}$ The overall impact of these contributions is difficult to quantify but they have undoubtedly had a positive effect in nurturing democracy in Malawi.

While this socio-political engagement continues to offer Malawians important lessons about democracy, the Catholic Church's engagement since 'Living our Faith' has not elicited the same level of public action as its 1992 pastoral letter did, with the possible exception of the interventions during the third-term proposals. This is perhaps not entirely surprising. After nearly three decades of sustained and unrelenting suppression of critical voices, the Church was uniquely placed in 1992 as one of the few platforms from which criticism of the one-party regime could be made without being silenced. Much of the power of the 1992 pastoral letter, therefore, lay in the fact that it voiced what everyone knew but few dared to say. Given the nature of democracy as a public good, ${ }^{38}$ it was not surprising that very few people were prepared to risk the wrath of the authoritarian regime by organizing for political change. The Catholic Church's institutional autonomy from the one-party state, on the other hand, provided an enabling context for it to challenge the hitherto invulnerable face of authoritarian rule and create opportunities for the emergence of a strong democracy movement. Although the clergy continue to occupy a respected place in Malawian politics, they are now just one of many actors in the liberalized political arena. The fact that the interventions by the Malawi Catholic Church after 1992 did not elicit the same level of response as 'Living our Faith' can be attributed to the success of the original intervention. Having created the space for the democracy movement to emerge, the Church was able to take more of a back seat in the democratic arena.

\section{Explaining the Malawi Catholic Church's shift from a passive to an active political mission}

While the important role the Catholic Church played in the emergence of the democracy movement in Malawi has been demonstrated, the question still remains as to why, given the long years of authoritarianism, the bishops only intervened in 1992 to spark off the process that led to the eventual rupturing of authoritarian rule. In taking on the might of the Banda regime, the Catholic

36 Lamp takes its title from the symbol of democracy proponents during the 1993 referendum.

37 See http://www.montfortmedia.org/, June 28, 2009.

38 Once available, democracy can be enjoyed by all citizens, including those who did not participate in its introduction. 
bishops obviously put themselves at significant risk. As Chakanza and Mitchell observed, the ruling party's initial response to the 1992 pastoral letter was one of defiance. ${ }^{39}$ The bishops were immediately arrested by the state police and placed under house arrest and an emergency session of the ruling MCP suggested that the bishops be killed and the Catholic Church banned.

Various circumstances, I would argue, combined to enable the Church to step in and challenge the Banda regime in 1992 in a way that had not been possible before. The first point to note is that the Catholic Church's intervention in the Malawian political arena in 1992 was partly a reflection of new theological developments within the Catholic Church worldwide: the Church was starting to embrace political engagement as part of its overall mission. Tracing its origins to the events of Vatican II, this new theology represented a transformation of the Church's understanding of its role in politics, shifting from a largely passive political entity to one of engagement in the quest for the promotion of the common good. ${ }^{40}$ Rejecting the notion that the Church should restrict its actions only to the religious field, Vatican II advocated 'acts of resistance when the rule of law is to be defended against abuses perpetrated by those who exercise public authority'. ${ }^{41}$ In the 1980 s, this position was reiterated by Pope John Paul II, who urged the clergy to advocate for the 'reform of unjust structures - in particular their political institutions', and to 'replace corrupt, dictatorial and authoritarian forms of government by democratic and participatory ones' ${ }^{42}$ In the Malawian case, the Catholic clergy were similarly called upon by John Paul II to stand up against 'injustice and oppression' when the pontiff visited the country in May $1989 .{ }^{43}$

Embracing this new political activism, Catholic clergy in various parts of the world played a central role in nurturing movements that helped to bring down dictatorial regimes. In Latin America, for example, Catholic 'liberation theology' was influential in the democracy movements that ousted the military re-

39 Chakanza, 'The pro-democracy movement in Malawi'; Mitchell, 'Living our Faith'.

40 A. Gill, 'Rendering unto Caesar? Religious competition and Catholic political strategy in Latin America, 1962-79', American Journal of Political Science, 38, 2 (1994), pp. 403-425; see also S. Bate, 'One mission, two Churches: the Catholic Church in southern Africa, 1947-1997', in J. Brain \& P. Denis (eds), The Catholic Church in Contemporary South Africa (Cluster, Pietermaritzburg, 1999), pp. 5-36.

41 Pope Paul VI, Gaudium et Spes: Pastoral constitution of the Church in the modern world, Encyclical, (www.vatican.va/archive/hist council/documents/vatii_cons 19651207 gaudium-et-spes_en.html, July 12,1965).

42 John Paul II, Sollicitudo Rei Socialis, Encyclical, (http://www.vatican.va/holy father/john paul ii/encyclicals/documents/hf ipii_enc_30121987_sollicitudo-rei-socialis_en.html, December 30, 1987).

43 Chakanza, 'The pro-democracy movement in Malawi'. 
gimes in the region. ${ }^{44}$ On the African continent, Catholic clergy played similar roles in challenging authoritarianism in countries such as Zambia, Ivory Coast, the former Zaire, Congo Brazzaville, Togo and Mali, to mention but a few examples. ${ }^{45}$ Criticism of authoritarian rule by the Catholic prelates in Malawi in the early 1990s was therefore part of a global activism by the Catholic Church, whose strength and influence had already been demonstrated in other parts of the world, as well as elsewhere in Africa.

While these developments were taking place within the Catholic Church, events on the international stage, particularly the end of the Cold War, combined to further weaken authoritarian rule in Africa and in the developing world in general. In the post-Cold-War era, authoritarian regimes could no longer be supported for simply favouring one side in the Cold War. Western aid donors made the introduction of democratic reforms a condition for the continued receipt of aid. In the case of Malawi, the Paris Donor Club's meeting of 11-13 May 1992, exactly two months after the release of 'Living our Faith', decided to withhold all budgetary aid pending the introduction of political reform and a greater respect for human rights. ${ }^{46}$ This suspension of aid weakened the authoritarian regime still further and increased opportunities for democracy groups to mobilize for institutional change. While it could be argued that the suspension of aid alone could have precipitated the emergence of a democracy movement, the sequencing of events in Malawi, where the suspension of aid came after the clergy had already intervened, meant that the donors' decision could only buttress a process that had been initiated by the Catholic prelates.

The importance of the Church in acting as the initiator of political change has to be understood within the context of authoritarian rule itself. While the authoritarian regime went to great lengths to insulate itself by eliminating independent centres of power, the Church, especially the Catholic Church, remained one of the few independent centres left. Indeed, in the run-up to the 1961 elections when the majority black population were allowed to vote for the first time, the Catholic Church did not side with the MCP, the then main nationalist movement, preferring instead to support the Christian Democratic Party (CDP) whose leader, Chester Katsonga, was himself a practising Catholic. ${ }^{47}$ Although it would be simplistic to suggest that the Catholic Church always had a fractious relationship with the Banda regime, it nonetheless enjoyed a

44 See P. Gifford (ed), The Christian Churches and Democratization in Africa (Brill, Leiden, 1995).

45 See J. Haynes, 'Religion and democratization in Africa', Democratization, 11, 4 (2004), pp. 66-89.

46 Muluzi et al., Democracy with a Price.

47 C. Baker, Revolt of the Ministers: The Malawi cabinet crisis, 1964-1965 (I.B. Taurus, London, 2001). 
higher level of autonomy from the state than other mainstream churches did in this period. For example, the CCAP Church, to which Banda and some of his senior lieutenants belonged, was more supportive of Banda as a person and of his government. ${ }^{48}$ The power of the Catholic Church as a key player in the political arena was buoyed by the growth in its membership over time. Although the Catholics were not the first Christian missionaries to arrive in what is present-day Malawi, the Catholic Church's membership has grown to three million out of a total population of about thirteen million, making it the country's single largest Christian denomination. ${ }^{49}$

The relative autonomy and independence of Malawi's Catholic Church as a countervailing force to authoritarianism was bolstered by its international character. The sense of belonging and accountability within a wider community of faith gave it an enhanced sense of independence within the highly totalitarian social and political structures prevailing in Malawi at the time. The significance of this international support was well demonstrated in the aftermath of 'Living our Faith' when messages of support for the bishops came from sister churches and interest groups in Malawi, Africa as a whole, the Vatican, the UK, the US, Canada and Europe. ${ }^{50}$ Not only did these messages express solidarity with Malawi's bishops, they also implored Banda to desist from using the draconian methods that he had relied on for so long to eliminate his opponents.

\section{The downside of the Catholic Church's political activism}

While the Catholic Church's socio-political activism initially contributed a great deal to the process of democratization in Malawi, its high-profile presence in the political arena since 1992 seems to have exacted some costs, particularly regarding developments in the democracy movement. A number of the key prodemocracy actors always now appear to wait and to take their cue from the Church before initiating any meaningful political action of their own because the Church, in the past, was seen to be at the heart of the movement. So dominant was the role of the Catholic Church in the political arena that Immink and Chigona suggest that 'it has become accepted that the participation [of the Catholic Church] is almost essential to the process of consolidating democracy in Malawi'. ${ }^{51}$ This over-reliance on the Church was demonstrated, for example,

48 See M. Kansilanga, 'Church and politics in Malawi today' (Address to the CCAP General Synod Human Rights Workshop, Chongoni, 8 November 1995, mimeo).

49 World Council of Churches, (http://www.oikoumene.org/en/member-churches/ regions/africa/malawi.html).

50 Chakanza, 'The pro-democracy movement'.

51 B. Immink \& G. Chigona, 'Between Apathy and Participation: The role of civil society and faith communities', in M. Ott, B. Immink, B. Mhango \& C. Peters- 
during the third-term debates between 2001 and 2003. Although the discussion on a possible third term for Muluzi started way back in 2000, civil-society organizations only began to seriously mobilize against the proposal after the Catholic prelates issued their 2001 pastoral letter criticizing the proposed constitutional amendments. And where the Catholic Church has remained silent on controversial political issues, such as the constitutional violations by Bingu wa Mutharika (President Muluzi's successor and a practising Catholic himself), the rest of the democracy movement has been equally silent.

\section{Conclusion}

This chapter has attempted to demonstrate how the Catholic Church served as an important stakeholder in precipitating the events that led to the emergence of the democracy movement in Malawi in 1992. While it would be a gross oversimplification to attribute the entire transition to democracy and its survival solely to the Catholic Church's political engagement between 1992 and 2008, no account of the process of democratization can ignore the significance of the Catholic Church's interventions, which began with the release of the historic 1992 'Living our Faith' pastoral letter. In a tightly controlled political system where political opposition was likely to result in a violent death, the pulpit became a powerful platform for criticism of authoritarian rule.

This chapter has also discussed the concept of 'path dependence' in the sense that if a democracy movement has received support from the pulpit, the men of robes remain central in nurturing it despite claims that the Church is apolitical and regardless of the emergence of new civil-society players, including political parties. Democratic progress in Malawi continues to be closely linked to the Catholic Church and the key challenge for the Catholic prelates remains when to let go and allow the democracy movement to wean itself from its spiritual origins. While the Church remains an active participant in the political arena, its participation is stunting the growth and maturity of democracy in Malawi.

Berries (eds), The Power of the Vote: Malawi's 2004 parliamentary and presidential elections (Kachere, Zomba, 2005), p. 139. 


\title{
8
}

\section{Bare-foot activists: Transformations in the Haratine movement in Mauritania*}

\author{
Zekeria Ould Ahmed Salem
}

Slavery was a widespread phenomenon in much of pre-colonial Africa but Mauritania stands out as one of the few African countries where it persisted as an entrenched institution even in post-colonial times. Mauritania also offers a rare example of an emancipation movement founded and run by slaves, ex-slaves and descendants of slaves. ${ }^{1}$ This pioneering social movement enabled people of servile origins to carve out a place for their protest actions in the public sphere. Previously, there had been isolated cases of slave revolts but El-Hor, an organization founded in March 1978 by activists of slave descent, developed into a social and political movement that ultimately entered the corridors of political power. El-Hor ('freeman' or 'emancipated' in Arabic) aimed to further the 'liberation and emancipation' of the 'heirs of slavery'.

This chapter does not intend to primarily document the history of this struggle as such, even though it is not widely known. Instead, it analyzes the transformations undergone by the Haratine movement since its first actions in 1980. To this end, I describe the trajectory of the collective action as it developed at the interface between society, politics and the struggle for civil

Article translated from French by Noal Mellott (CNRS, Paris).

1 Roger Botte, 'De l'esclavage et du daltonisme dans les sciences sociales. Avantpropos', Journal des Africanistes, 70, 1-2 (2000), p. 13; Éric Komlavi Hahonou, 'Cultures politiques, esclavage et décentralisation. La revanche politique des descendants d'esclaves au Bénin et au Niger', Politique africaine, 111 (2008), pp. 169186.

2 A. Daddah, 'Les héritiers de l'esclavage. La longue marche des Haratines', Le Monde Diplomatique, November 1998. 
and human rights. The focus is on the movement's origins and the successive changes in its form of organization, types of actions and the outcome of its activism.

\section{Context and origins}

Located between the Western Sahara to the north and the Senegal River to the south, the Islamic Republic of Mauritania has a population of about three million. ${ }^{3}$ Its geographical position between the Arab world of North Africa and Black Africa explains some of the ambiguities in Mauritania's complex national identity: Arab or/and African? Mauritanians are divided along lines of race and ethnicity as well as social status. In terms of race, the main division is between Black African Mauritanians or Afro-Mauritanians and so-called 'White' ArabBerbers or Moors. Given the lack of official up-to-date statistics, it is assumed that nearly $30 \%$ are ethnic Black Africans (in particular, Haalpulaar, Soninke and Wolof). Arab-Berber Moors make up the majority of the population and refer to themselves as bidhân ('Whites') even though more than half of them are, in fact, Black Moors.

In terms of social status, the legacy of slavery is still a crucial factor in the social hierarchy of Mauritanian society today. Among both the Afro-Mauritanians and the Moors, there is a clear divide between the masters and the slaves or people of slave descent. Although this social division is often expressed in racial terms - white masters and black slaves - race and class do not fully coincide. More than half of the Moors are Black Moors or Haratine, a group primarily made up of slaves ( $\hat{a} b i d$; singular: ' $a b d$ ) and of persons freed from slavery (hratîn, singular: hartâni) and their descendants. In Afro-Mauritanian society, masters and slaves have the same skin colour and servitude is less visible than in Moorish society. Activists claim that more than half of the total population is of servile origins, but this remains disputed.

Moorish society has always practised 'chattel slavery', ${ }^{4}$ usually based on racial differences (Black slaves with Arab-Berber masters) and covered by a conservative interpretation of Islamic law. The considerable number of former slaves is evidence that slavery prevailed on a large scale and for a long time. This chapter focuses on the emancipation movement among the Haratine. Moor slaves and ex-slaves have no common cause with the Afro-Mauritanian slaves and although they share the stigma of servile status, they are divided by language and historical experience. Among Afro-Mauritanians, slavery is less

3 Zekeria Ould Ahmed Salem, 'Mauritania, a Saharan frontier state', Journal of North African Studies, 10, $3 / 4$ (2005), pp. 491-506.

4 Joel Quirk, Unfinished Business: A comparative survey of historical and contemporary slavery (UNESCO, Paris, 2008), pp. 105-107. 
visible and the main features of servitude have been more or less successfully challenged by the authorities since the colonial period. Being of slave status carries a social and cultural stigma but it is not formally entrenched in the same way as in Moorish society. Paradoxically, this makes it more difficult for AfroMauritanians to organize in an emancipatory movement. The Haratine not only had the advantage of carrying more demographic weight but also had a more tangible cause as their subordinate status was an overt, undeniable fact.

\section{Slavery past and present}

In the traditional nomadic environment, slaves were ineluctably assigned the hardest tasks. ${ }^{5}$ They experienced 'social death ${ }^{6}$ and total economic exploitation and in terms of Islamic law were considered legal minors. ${ }^{7}$ Questioning the legitimacy of slavery has often been considered going against the national religion. Under Islamic law, slaves are not free to marry, cannot own goods in their own name or inherit property. Nor can they dispose of their own children or bear testimony before a court of law. Freedom and emancipation are valid only if duly granted by the master. The sale or conveyance of slaves as well as jus primae noctis were practised until recently. Slaves laboured under a kinship system that was all the more fictive since they belonged - in both senses of the word - to their master's family. ${ }^{8}$

Slaves and former slaves do not exist in the Arab-Berber group alone. Servitude was solidly rooted in the rigid social hierarchy of all groups in Mauritanian society regardless of ethnic origin. ${ }^{9}$ The stigma of enslavement represented a widespread symbolic form of violence. When asked about this, El-Hor's historic leader, Messaoud Ould Boulkhier, declared:

5 Abdel Wedoud Ould Cheikh, Nomadisme, islam et pouvoir dans la société maure précoloniale (XIe-XIXe siècles). Essai sur quelques aspects du tribalisme (University of Paris V, Paris, PhD dissertation, 1985), p. 453.

6 Orlando Patterson, Slavery and Social Death (Harvard University Press, Cambridge, MA, 1982).

7 Meskerem Brhane, Narratives of the Past, Politics of the Present: Identity, subordination and the Haratines of Mauritania (University of Chicago, Chicago, $\mathrm{PhD}$ Dissertation in Political Science, 1997).

8 Benjamin Acloque, Identité et statut de dépendant en Mauritanie. L'exemple de l'identité sociale des Hratin dans le système segmentaire et hiérarchique Bidan (University of Paris X-Nanterre, Paris, Masters thesis, 1995), p. 41.

9 Ousmane Kamara, 'Les divisions statutaires des descendants d'esclaves au Fuuta Tooro mauritanien', Journal des Africanistes, 70, 1-2 (2000), pp. 265-289; Yaya Sy, 'L'esclavage chez les Soninkés: du village Paris', Journal des Africanistes, 70, 1-2 (2000), pp. 43-69; and Olivier Leservoisier, "Nous voulons notre part!” Les ambivalences du mouvement d'émancipation des Saafaalbe Hormankoobe de Djéol (Mauritanie)', Cahiers d'études africaines, 179-180 (2005), pp. 987-1014. 
Slavery also exists among Black Africans [...] I prefer my condition to theirs. The Black African slave, in his society and mind, is forced to die a slave; and his children too. Whereas I, a Haratine, am fighting to break out of this condition, they prefer presenting it as a specifically Moorish case and refuse to talk about what is happening among themselves. ${ }^{10}$

The country's successive governments have never addressed the issue of slavery as such regardless of the ethnic groups involved. The colonial administration widely tolerated such practices ${ }^{11}$ and traditional slavery survived for a long time in post-colonial Mauritania. The public authorities have always adopted an ambiguous stance, combining denial, embarrassment and laisserfaire. $^{12}$

Year after year, organizations involved in the fight against slavery are still reporting dozens of cases, although they usually refrain from estimating the number of victims. Mauritania is presented as an extreme case when it comes to slavery ${ }^{13}$ and sometimes, in a simplified manner, ${ }^{14}$ as an absolute counter example. ${ }^{15}$ The aspiration to freedom still encounters barriers in odd situations in a country where, despite laws on abolition, the Constitution's preamble recognizes Sharia law as the main legal system. As applied by the customary courts, the pro-slavery interpretation of a not very codified Islamic law has led to litigation and disputes, sometimes inextricably in matters of inheritance, marriage, child custody, land ownership and salaries. ${ }^{16}$

The sizeable community that is descended from slaves still forms the country's most underprivileged social category. ${ }^{17}$ The Haratine experience inferior economic, social and political conditions and if they are free, their freedom is

10 Interview with Messaoud Ould Boulkhier in L'Autre Afrique, 57, 6 August 1997, p. 26.

11 El Kehel Ould Mohamed El Abd, Colonisation française et mutations sociales en Mauritanie: Cas de l'esclavage en milieu maure, 1900-1960 (University of Nouakchott, Nouakchott, Master's thesis in History, 1987).

12 Mohamed Lemine Ould Ahmed, L'abolition de l'esclavage en Mauritanie (University of Dakar, Dakar, Master's thesis in International Relations, 1983), pp. 5-6.

13 Amnesty International, Mauritania: A future free from slavery? (Amnesty International, London, 2002).

14 Thierry Desjardins, 'Mauritanie: 700.000 esclaves qui veulent le rester', Le Figaro, 8 December 1995; Samuel Coton, Silent Terror: A journey into contemporary African slavery (Harlem River Press, New York, 1998).

15 Kevin Bales, Disposable People: New slavery in the global economy (University of California Press, Berkeley, CA, 1999).

16 Zekeria Ould Ahmed Salem, 'Droit du statut personnel et équivalence citoyenne en République Islamique de Mauritanie. Le cas du mariage’, La Pensée, 336 (2003), pp. 37-53.

17 E. Ann McDougall, 'Living the legacy of slavery: between discourse and reality', Cahiers d'études africaines, 179-180 (2005), pp. 957-986. 
usually meaningless owing to their low economic status since they have subaltern jobs in urban or rural areas. Strongly marked by current and past slavery, their emancipation is limited due to the poverty in which most of them still live. Since political or legal emancipation has never been fully enforced, other factors have rekindled the debate about the abolition of slavery and bringing the Haratine issue to public attention. ${ }^{18}$ The Haratine community has been politically shaped through struggles that have developed out of social, political and even ecological changes that need to be studied. ${ }^{19}$

\section{An unlikely cause?}

It is usually, and rightly, claimed that several factors have contributed to the emergence of the Haratine cause. Severe droughts in the 1970s undermined the conditions underlying both slavery and the agro-pastoral economy that corresponded to the traditional way of life. ${ }^{20}$ By forcing most of the nomads to move to urban areas, this environmental catastrophe left many slaves destitute. Then the war in the Sahara, in which Mauritania was involved from 1975 to 1978, levied a large number of troops from among the Haratine who, in turn, gained a degree of collective emancipation. Finally but to a lesser degree, several young Haratine graduates decisively increased their group's social visibility. It was no accident that El-Hor came into being in 1978, the year in which all these processes came to a head.

Collective demands on behalf of both slaves and former slaves were voiced in a society used to the liberation of individual slaves as they were manumitted or ran away. Apart from a few isolated and sporadic revolts, an organized challenge had never been mounted to the institution of slavery. It had barely figured on the leftist agenda advanced by young political activists during the period of unrest between 1968 and 1974; and the arguments used by local Marxist groups usually omitted it. Preferring the classical dichotomy bourgeoisie/proletariat, the major underground movements at the time - the Parti des Kadihines (PKM) and Mouvement national démocratique (MND) - mainly sought to provoke the neo-colonial authorities. However, the few people with

18 Zekeria Ould Ahmed Salem (ed.), Les trajectoires d'un État-frontière. Espaces, évolutions politiques et transformations sociales en Mauritanie (Codesria, Dakar, 2004).

19 Abdel Wedoud Ould Cheikh, 'L'évolution de l'esclavage dans la société maure', in E. Bernus \& P. Boilley (eds), Nomades et commandants. Administration et sociétés nomades dans l'ancienne AOF (Karthala, Paris, 1994), pp. 181-193.

20 Urs Peter Ruf, Ending Slavery: Hierarchy, dependency and gender in central Mauritania (Transcript Verlag, Bielefeld, 1999). 
slave origins who became involved in these movements gained basic training in methods of collective organization.

The educated members of the Haratine elite established El-Hor on 5 March 1978. Among its best-known leaders were Messaoud Ould Boulkheir (a civil servant), Boubacar Ould Messaoud (an architect), Mohamed Ould Haimer (a primary-school teacher), Boydiel Ould Houmeid and Achour Ould Samba (who would later be civil servants) and Mohamed Lemine Ould Ahmed and El Kehel Ould Mohamed El Abd (who would become academics). The movement also received support from several school teachers and students.

Before examining the organization's initial actions and transformations, let us take a look at its founding charter that formulated a sense of identity and set a political agenda.

\section{Haratine nationalism: El-Hor's charter}

El-Hor's charter (a preamble and three articles) was circulated clandestinely, like many other political tracts at that time. In addition to demands concerning the abolition of slavery, it offered a genuine plan for an infranational 'imagined community ${ }^{21}$ founded on a 'moral ethnicity'. ${ }^{22}$ According to the preamble, 'the Haratine of Mauritania are still subject to forms of domination, oppression and exploitation' in spite of national and international legal measures. There was therefore the 'necessity of their collective consciousness and unified struggle'. This moral ethnicity did not aim to include all Mauritanians of slave descent, only those who shared a common Moorish ethnicity as well as a knowledge of Arabic. The key to liberation was to develop awareness among the Haratine: cognitive liberation was a precondition for social action.

After the first article stating the movement's name, the two other articles were devoted respectively to 'general political orientations' and 'objectives'. In proclaiming their movement's absolute autonomy - 'El-Hor does not identify itself with any other organization or movement' - the authors claimed that their actions were 'national, non-racial, anti-segregationist and anti-chauvinistic'. ElHor called upon 'all persons of goodwill, individual, collective, national, foreign and international, for support in the just struggle to uphold inalienable human rights' (II-3). Article III states the reasons underlying the movement's existence:

21 B. Anderson, Imagined Communities: Reflections on the origin and spread of nationalism (Verso, London, 1983).

22 J. Lonsdale, 'Moral ethnicity and political tribalism', in P. Kaarsholm \& J. Hultin (eds), Inventions and Boundaries: Historical and anthropological approaches to the study of ethnicity and nationalism (Roskilde University, Institute of Development Studies, Roskilde, Occasional Paper 11, 1994), pp. 131-150. 
Fundamentally inspired by religion, exacerbated by an abusive interpretation of this religion by the privileged social strata, and maintained owing to the ambiguity or even the nearly complete silence in the country's legislation, the inequalities from which the Haratine suffer are not just economic, social, political and religious. They are also, and above all, inherent in a mentality with deep roots due to centuries of psychological conditioning. Fighting against all that is El-Hor's raison d'être.

Regarding the system of land tenure, the manifesto calls for reform so that those who work the land (i.e. the Haratine) own it themselves. Secondly, El-Hor announced its intention to fight slavery and all forms of unpaid labour, promising to focus on combating discrimination in education, which was especially important for the Haratine, and in particular those in rural slave ghettos (adwa$b a$, singular: adabay). Blaming the government for its 'policy of obstruction' that kept the Haratine out of decision making, El-Hor demanded an 'actual participation in the exercise of power at all levels', starting with the (then single) party, the civil service and elective offices.

What stands out in this charter is the rejection of an Islam that endorsed slavery and justified the inferiority of the Haratine. It thus asked the Haratine to categorically oppose this religious conception. El-Hor demanded the abolition of slavery and devoted its efforts to modernizing Islamic law and jurisprudence. It asked the government to 'remove all the contradictions that exist between Muslim and modern law, in particular those having to do with the slave status, namely: the problems related to the incapacitation of slaves (property rights, testimony, inheritance) and to matrimony (marriage, concubinage)'. This represented ultimately a twofold form of subversion. The movement not only claimed to propose its own interpretation of Koranic law - one squarely opposed to the jurisprudence used in local Islamic circles - but did so from a social position - slave or freed slave - that was the least 'qualified' to make such an interpretation.

The charter's final article focused on the Haratine identity. The Haratine were 'insoluble' in any other ethnic group in Mauritania even though they belong, it is clearly stated, to the Moorish community. El-Hor opposed dividing the Haratine into sub-groups according to their degree of bondage or freedom, in particular the difference between those emancipated long ago (khadhara), recently (hratîn) and those who were still slaves (abid). The nascent organization deliberately used general language in an effort to be inclusive and claimed to represent a homogeneous community that saw status differences as secondary in comparison to an identity labelled 'Haratine'. However this label was not chosen at random since it refers literally to emancipated slaves. In fact, the charter uses the word 'slavery' only once, to categorically reject slavery. After explaining how the Haratine identity set this group apart from other Mauritanians, it concluded by proclaiming the cultural and historical specificity of the 
Haratine. It was El-Hor's duty, through its programme, to consolidate this specificity and obtain recognition for it. ${ }^{23}$

El-Hor intended less to overturn Mauritania's power structure or society than to become a full-fledged active part of it. The Haratine movement did not develop a radical or revolutionary vision. In later texts, El-Hor glorified fraternity with the Haratine, stating that it did not intend to seize power, even though its demands upset traditional and established holders of power. ${ }^{24}$

The charter galvanized Mauritanian society. Having successfully carved out a place for itself in the public sphere, El-Hor advanced its cause in the field through actions. It diffused its slogans in areas traditionally settled with slaves $(a d w a b a)$ and on the impoverished margins of the urban areas where the Haratine were concentrated. It organized demonstrations and, by setting up 'cells', built up a territorial network through its work of conscientization (wake-up campaigns). Meanwhile, El-Hor was explaining the conditions of the Haratine to political organizations and officials although raising the taboo on talking about slavery met with circumspection and sometimes even hostility.

\section{A subversive movement: El-Hor as seen by others}

The Mouvement de libération et d'émancipation des Haratines was launched while a single party was in power. The Parti du peuple mauritanian had managed to incorporate nearly all protest movements since 1974 and given that the major political issue at the time was the country's involvement in the war in the Sahara, domestic politics were relatively calm. In this context, the public authorities wondered whether the time was ripe for a debate on the Haratine cause. However politicians were all baffled by, or even fearful of, an endogenous movement that was led by, and based on, an elite drawn exclusively from within the Haratine community. Small political groups saw the movement as serious competitor in a potential segment of the political market place.

What irritated people even more was the movement's claim that it had authentic roots in Mauritania, whereas most of the underground 'parties' (the MND as well as Black African or Arab-Mauritanian nationalists) embraced imported ideologies (proletarian internationalism, pan-Africanism, Nasserism, Baathism). El-Hor accused certain rivals of being ideological foreigners without any attachment to a genuinely national cause.

Another annoyance was that the Haratine wanted to assert themselves as a new autonomous national force in a context where political groups formed on an ethnic basis were vying for this community's support. The Moorish elite saw

23 El-Hor, 'Charte constitutive' (Nouakchott, 5 March 1978) quoted in L'Ouest saharien-Cahiers d'études pluridisciplinaires 4 (L'Harmattan, Paris, 2004), pp. 183-188.

24 Mouvement El Hor, Hartani, mon Frère (Akhukal Hartani), tract (1978). 
El-Hor as a threat of discord within a purportedly unified community. In their view, the formation of a movement of Moors of servile descent undermined the automatic majority of the Arab-Berber group. They did not perceive the issue in terms of an oppressive ruling class and a subjected underclass campaigning for full civil and social rights. In this perspective, El-Hor disadvantageously complicated the situation given the delicate ethnic balance in a country where the only noteworthy cleavage in their eyes was between Moors and Black Mauritanians. ${ }^{25}$ The Haratine movement arose at a time when Black Mauritanian nationalists were not very active, and the latter did not accept the creation of an organization for a group that they had hoped to rally so as to tip the population's racial balance in their favour. Their concern was even more justified since ElHor was established during a war to acquire territory inhabited by White Moors in the Western Sahara. With the obvious demographic consequences, Black Africans were rightly fearful in case they definitively remained a minority in the country.

This generally hostile reception did not hinder the new movement. Due to the relative diversity of the Haratine, the utopia of a unified community had, of course, limited appeal and the majority of the people targeted were not particularly influenced by El-Hor's arguments. Through a window of opportunity, the organization managed to obtain results, sometimes because of its sweeping actions during the first years of its existence.

\section{A successful movement: Time to act}

The Haratine movement emerged as the regime of Moktar Ould Daddah, Mauritania's first president, was drawing to a close. The president was ousted by a coup on 10 July 1978, an event that overshadowed the slave revolts that were being quelled in various localities. ${ }^{26}$ Like other small political groups, El-Hor organized a demonstration in favour of the new authorities and even signed, in the name of the Haratine community, a petition supporting them. It thus presented itself as a player on the national scene.

Meanwhile, El-Hor's activists were making themselves heard internationally. An awareness campaign was launched to reach out to the media and relevant NGOs, and it soon bore fruit. Anti-Slavery International, based in London,

25 Philippe Marchesin, Tribus, ethnies et pouvoirs en Mauritanie (Karthala, Paris, 1992).

26 Ould Ahmed, L'abolition de l'esclavage en Mauritanie, pp. 57-60. 
started to work with El-Hor to assess the scope of slavery, ${ }^{27}$ as can be seen in its report on Mauritania. ${ }^{28}$

However the real opportunity to go public came two years after the organization's creation, in July 1980, when the power of the state was shaken due to difficulties ending the country's involvement in the war in the Western Sahara. In April 1979, Colonel Mohamed Khouna Ould Haidalla had replaced colonels Moustapha Ould Mohamed Saleck and Mohamed Mahmoud Ould Mohamed Louly, the two successive heads of state since 1978. A specific event pushed El-Hor to organize protest demonstrations in several big towns including Nouakchott, Rosso and Nouadhibou after news broke of the sale of a slave named M'Barka in the town of Atar (Adrar) in February 1980. After activists were arrested, El-Hor were taken to court in Rosso in March 1980.

In this famous case and in line with argumentation frequently used afterwards, the Mauritanian authorities made it a crime to raise the issue of slavery. El-Hor's founding members (Boubacar Ould Messaoud, Boydiel Ould Houmeid, Achour Ould Samba and Samory Ould Beye as well as several other persons) were arrested, imprisoned, interrogated and finally arraigned before a military tribunal that held special hearings in Rosso. Most of the accused willingly admitted what they had done and that they had belonged to the movement. ${ }^{29}$ They managed to turn the trial into a grandstand for their cause and it became an opportunity far beyond anything the anti-slavery activists could have hoped for and made a strong impact on the media. El-Hor's leaders received prison sentences of up to three months but the publicity surrounding around the trial would soon have spectacular effects both nationally and internationally.

\section{The march towards abolition}

The government of Ould Haidalla seemed to have decided to respond to Haratine demands and, in addition to the trial's impact and international support, the campaigns launched by El-Hor soon proved effective. In June 1980, the organization published a tract listing the major problems related to the continuation of slavery and asked the government to address these grievances.

As a result of international pressure and instability on the domestic front, the government responded rapidly and forcefully. ${ }^{30}$ Hardly able to do otherwise, it

27 Ibid., p. 61.

28 John Mercer, Slavery in Mauritania today (Anti-Slavery International, London, 1981).

29 I would like to thank R. Botte for providing me with copies of the proceedings of this trial.

30 Interview with Mohamed Khouna Ould Haidallah in Espaces Calame, 3, March 1994, p. 6. 
was moving towards the formal abolition of slavery. It started by consulting ulemas. Their approval was less than outright and their fatwas were reserved. None proclaimed that slavery was illegal under Islam, but neither did any go so far as to advise against the proposed measure. Given the ambiguity of the doctors of Sharia law, the Home Office issued a statement on 3 June 1980 that instructed the regional authorities to combat an 'anachronistic practice'. On 5 June 1980, the Comité militaire de salut national, the governing body at the time, adopted a declaration abolishing slavery. The government newspaper enthusiastically explained the measure by borrowing from El-Hor: 'Since all Muslims are equal before Allah, there is no reason some of them should be enslaved by others'.

Activists criticized all these efforts as being legally worthless and the authorities were forced, sixteen months later, to go a step farther and issue a decree abolishing slavery on 9 November $1981 .^{32}$ Its four short articles were ambiguous, oddly providing for state compensation for the 'persons entitled', i.e. the masters. Nonetheless, this order clearly signalled a victory for El-Hor. The law recognized that there were still slaves being treated like someone else's personal property since their owners were to be compensated for their losses. ${ }^{33}$

Later, Ould Haidallah's government issued its famous order for land reform in June 1983. Since land was to be held by individuals, the tribal authorities' traditional property rights were to be abolished. This law was supposed to allow slaves to own the land they worked ${ }^{34}$ and was one of President Haidalla's last political acts before he was ousted by Colonel Mâaouya Ould Sid'Ahmed Taya on 12 December 1984. Taking into account the momentum gathered by the movement in the Haratine community, the new head of state appointed Messaoud Ould Boulkhier as Minister of Rural Development. This founding member of El-Hor received, it was claimed, the symbolically important assignment of land reform because there was to be a new policy of improving the conditions of the Haratine at the local level.

Beyond its symbolism, this appointment marked a turning point. First of all, it opened up access to decision-making positions to the Haratine elite. Secondly, it was evidence of the determination to endorse at least some of the conclusions drawn up by El-Hor. And finally, it signalled government recognition of El-Hor as a legitimate representative and spokesman of the Haratine community. Since then, no government has been formed without including at least some persons

31 Chaab, 7 July 1980.

32 Ordonnance n. 81.234 of 9 November 1981.

33 Mohamed Lemine Ould Ahmed, L'abolition de l'esclavage en Mauritanie, pp. $67 \mathrm{ff}$.

34 Bernard Crousse, 'La réforme foncière mauritanienne de 1983, étatisation ou individualisation', Politique africaine, 21 (March 1986), pp. 63-76. 
from this community, ${ }^{35}$ preferably from among El-Hor's founding members. This involvement in government considerably affected the movement's institutionalization and political prospects during Mâaouya Ould Taya's long term in office (1984-2005) and even beyond.

\section{'Slaves' in power, 'slaves' of power}

A major objective of El-Hor's founding charter seemed to have been achieved: persons from among the Haratine were now holding top positions. The process of turning the Haratine leadership into 'officials' was seen literally and the movement's request to share the national pie among the country's ethnic, tribal and social constituents started to be realized. ${ }^{36}$ Since then, nearly all of the movement's outstanding members have held important positions in government and the Haratine movement can lay claim to considerable political advances. During the experimental municipal elections organized by Ould Taya in late 1986, El-Hor was less successful but was able to measure the support it had in the country. By sponsoring candidates, it gained electoral experience that would prove useful later. ${ }^{37}$ Beyond the pursuit of personal careers, what was important about this involvement in politics was the position that the Haratine were working out in the recurring debates on Mauritania's national identity.

The experience gained in management and political office-holding spawned rivalries for the control of a movement increasingly involved in politics in the second half of the 1980s when the racial divide between Arab-Berbers and Afro-Mauritanians resurfaced along with the related issues of power-sharing and national identity.

\section{Identity politics and the Haratine cause}

The Forces de libération africaines de Mauritanie (FLAM), formed in 1986, signalled a radicalization of the claims made by Black African nationalists. In its famous 'Manifesto of the Oppressed Negro-Mauritanian', this new group called for armed struggle against Ould Taya's regime. The resurgence of the question of Black African minorities and their hostility towards the government, which was accused of being racist and of being monopolized by the White

35 Zekeria Ould Ahmed Salem, 'Sur la formation des élites politiques et la mobilité sociale en Mauritanie', Nomadic Peoples, 2, 1-2 (1998), pp. 253-276.

36 Zekeria Ould Ahmed Salem, 'La Centralité de la mobilisation tribale dans l'action politique en Mauritanie: Une illusion bien fondée?', L'Ouest Saharien, 2 (1999), pp. 127-156.

37 El Arby Ould Saleck, Les Haratins. Le paysage politique mauritanien (L'Harmattan, Paris, 2003). 
Moors, took a decisive turn in October 1987 with the failed coup by Haalpulaar officers. The three major instigators were tried by a military tribunal, sentenced to death and executed shortly afterwards. Dozens of presumed accomplices were thrown into prison and the Black African peril was declared a 'menace to state security'.

During all this, the long-standing debate on the country's identity was still raging. Two radical groups - the Moors and the Black African Mauritanians were trying to win the Haratine community's support. An Arab nationalism of many forms (Nasserism, Baathism, etc.) was thriving, even in the military, opposing the idea of an African identity for Mauritania. In this tense atmosphere, El-Hor tried to present itself as separate from these competing nationalisms that were trying to recuperate the Haratine movement. From its very foundation, the organization had, in principle, adopted a position on the question of identity that was reflected in its well-known slogan: 'Arab but Black, Black but Arab'. Nevertheless, a debate flared up within the organization. Among El-Hor's few official declarations on this question was one from Boubacar Ould Messaoud (who would later head SOS Esclaves) to a Senegalese newspaper: ${ }^{38}$

My skin is not a political programme [...] They are trying to establish a link between the activism of a few persons who have proclaimed themselves the spokesmen of a Black Mauritanian pseudo-community and the problem of slavery [...] In 1980, the fight against slavery was [led by] El-Hor, not them.

This heated controversy took a new turn following the clash between Mauritania and Senegal in April 1989, as citizens from each county living in the other were targeted. During these so-called 'events', as was the case during similar riots in 1966, the Haratine were accused of taking part in acts of violence against Black Africans, Senegalese and Mauritanians. It was even claimed that some Haratine had joined in the riots because of the aggression in Dakar against Bilal Ould Werzeg, a diplomat at the embassy and a founding member of ElHor. ${ }^{39}$ Whatever the case, the expulsion of nearly 80,000 Black African Mauritanians to Senegal and Mali caused unprecedented humanitarian problems while shortly afterwards, in 1990/1991, about 300 Black African soldiers fell vicitm during a bloody purge when they were accused of being antinationalistic and of supporting FLAM's 'extremist' doctrines. The death toll continued to rise. Black African nationalists did not give up on recruiting the Haratine for their combat. In 1990 FLAM's newspaper was tellingly called Bilaal after the first

38 Sud Magazine 4, January 1987, p. 1.

39 Charles C. Stewart, 'Une interprétation du conflit sénégalo-mauritanien', Revue du Monde Musulman et de la Méditerranée, 54, 1 (1989), pp. 161-170. 
slave to convert to Islam and who became a well-known follower of the Prophet. $^{40}$

Contradictions were emerging within El-Hor at this time. Some of the leaders supported the regime while others did not want to have anything to do with the military. The movement was also suffering from rivalries based on regions (east vs. southwest), language education (Arabic vs. French) or even ideologies. The desertion in 1990 of some of the leaders to join a group of Baathist Moors was seen as a defeat by some Haratine activists who wanted to remain equidistant from both Arab and Black African nationalisms.

The Haratine leadership remained divided over the question of whether to carry forward the symbolic issue of slavery. Since its foundation, the movement had often discussed if it should have a political or a social calling and this question was emerging once again. A rift was opening between a so-called radical wing that advocated pursuing this struggle and a more moderate wing for whom the Haratine issue was no longer political but social and economic. Positions hardened as a political strategy was hammered out and regardless of whether or not most of the Haratine felt represented by El-Hor (a hard-toanswer question), the organization turned out to be less of a federating, unifying force when circumstances forced it to position itself in a new political arena.

\section{El-Hor, power holder or democratic opposition?}

Before democratic fever broke out in Africa, part of El-Hor was increasingly at odds with Ould Taya's regime. In late 1990, certain members of the radical wing demanded political pluralism, blaming the authorities for undermining ElHor's ticket (led by Messaoud Ould Boulkheir) during the 1990 municipal elections in Nouakchott. While several founding members sided with the regime (Boydiel Ould Houmeid, Mohamed Lemine Ould Ahmed, Sghair Ould Mbareck and Mohamed Ould Haimer), an active minority (Messaoud Ould Boulkheir, Boubacar Ould Messaoud and Omar Ould Yali) did not. The latter were among the leaders who sent open letters ('from 50', then 'from 150') to the head of state asking him to open political doors. Boubacar Ould Messaoud, who was thought to be close to the authorities, paid the price for this and was immediately dismissed from the official position he held.

Under mounting pressure from within and outside the country, President Ould Taya declared a pluralistic democracy on 15 April 1991. After laws installing a multiparty system were passed, Ould Taya's opponents joined the Front démocratique uni pour le changement (FDUC) in July 1991. This party included most of the political forces that wanted to put an end to the military

40 Marianne Marty, 'Les multiples usages de l'Islam dans le champ politique mauritanien', in L'Afrique politique 2002 (Karthala, Paris, 2003), p. 57. 
regime and, once legalized under its new name of Union des forces démocratiques (UFD), the front became the principal opposition party. Created for the presidential and legislative elections in 1992, the UFD was co-directed by Messaoud Ould Boulkheir, which was undoubtedly the reason why the issue of slavery had a place on the party's platform and it condemned violations of the human rights of Black African Mauritanians, civilians and soldiers.

The UFD supported an independent candidate, Ahmed Ould Daddah, for the presidential election on 24 January 1992 since support for Ould Boulkheir's candidacy had not been unanimous. The UFD did not survive Ould Daddah's defeat in an election that was only just won by Ould Taya under tense and dubious conditions. A new party, Union des forces démocratiques/Ère nouvelle (UFD/EN), formed around Ould Daddah but the leaders of El-Hor felt cramped in this new organization and, in 1993, dissatisfied with the handling of the Haratine question, El-Hor published a long document recounting its fight and discussing its uncomfortable position inside the party. ${ }^{41}$ However its representatives did not quit the UFD/EN until 1994 and they created Action pour le changement (AC) in August 1995 with Messaoud Ould Boulkheir as president. ${ }^{42}$

\section{Autonomy in party politics and the rekindled debate on slavery}

The Haratine movement was now deeply entrenched in party politics. Though founded by persons of different origins, the $\mathrm{AC}$ was the first party actually controlled by Haratine. Since it accepted forming an alliance with Black African nationalists who had previously been activists in the UFD, its creation was seen as a radicalization of El-Hor. The AC was the first party to present a platform that gave priority to the fight against slavery and the advancement of the Haratine. Given the context, the party's creation was hugely significant and as an authoritarian restoration was taking place, the regime was cleverly manoeuvring to 'pass the democratic test' and enhance its image outside the country. Above all, it was acquiring a reputation of stability in a region that was relatively less secure. ${ }^{43}$ Mauritania established diplomatic relations with Israel, thus improving its relations with the United States and muting the frequent criticism directed at it from America.

El-Hor apparently realized that its cause had not only been watered down owing to its involvement in party politics inside the country but had also been

41 El-Hor, 'Les Haratines. Contribution à une compréhension juste de leur problématique', Nouakchott (5 March 1993), 28 typed pages.

42 El Arby Ould Saleck, 'Les Haratin comme enjeu pour les partis politiques en Mauritanie', Journal des Africanistes, 70, 1 (2000), pp. 255-263.

43 Zekeria Ould Ahmed Salem, 'La démocratisation en Mauritanie, une illusion postcoloniale?’ Politique africaine, 75 (October 1999), pp. 131-146. 
hijacked by political groups outside the country, in particular Black African Mauritanians in the USA. ${ }^{44}$ The creation of the AC and, in the same year, of SOS Esclaves has to be understood in this context. The Confédération libre des travailleurs de Mauritanie (CLTM) was also set up under the leadership of Samory Ould Bèye, one of El-Hor's founding members.

These political changes were occurring while the terms of the debate about the Haratine problem and slavery were slowly shifting. Since democratization in 1991, two opposite positions on slavery had formed in the country's independent media. According to El-Hor activists in opposition, slavery still existed as a practice and as a system of values fostered by a lack of action by the authorities. According to the regime's supporters, slavery had vanished and any actions should be directed at its mainly economic and social after-effects. Mentioning the existence of slavery amounted to an attack on national unity. The activists who adopted the first position were accused of manufacturing a fake problem for political purposes. The El-Hor faction that had joined the regime was even assigned the task of confronting their brothers in arms about this question. A Comité pour l'éradication des séquelles de l'esclavage en Mauritanie (CRESEM) was formed for this purpose in the mid 1990s and in 1997 it received the public support of the head of state who, during a famous speech, criticized politicians' exploitation of slavery's after-effects, setting off a major national debate that reflected, once again, a hardening of positions on the issue. ${ }^{45}$

This tension eventually affected the AC's political prospects. Having won but a single seat (Kébé Abdoulaye) in the 1996 parliamentary elections, the party was not represented in the National Assembly by anyone from El-Hor. In the more legitimate 2001 legislative elections however, it won four seats in parliament, including that of the charismatic Messaoud Ould Boulkheir.

The UN conference in Durban on racism and xenophobia (August-September 2001) provided El-Hor activists with a platform for reaching the international media. Since the early 1990s, the issue of slavery in Mauritania had been monopolized by Afro-Mauritanian activists abroad who had presented the issue in black-and-white terms. In their simplified version, in which all AfroMauritanians were the slaves of the Arabs, there was obviously no role for ElHor. ${ }^{46}$ El-Hor activists used the Durban conference to censor the regime's

44 Alice Bullard, 'From colonization to globalization: The vicissitudes of slavery in Mauritania', Cahiers d'études africaines, 179-180 (2005), pp. 751-769.

45 Mohamed Lemine Ould Ahmed, Mauritanie-Nouvelles, 236, 28 January 1997, pp. 12-13.

46 Interview with Messaoud Ould Boulkheir in Le Calame 351, 8 May 2002; Michele Stephenson, Faces of Change, a documentary (Firelight Media Production, New York, 2002), $22 \mathrm{~min}$. http://www.firelightmedia.org. 
authoritarian restoration in Mauritania and its treatment of 'bare-foot activists', as Messaoud Ould Boulkheir and his comrades referred to themselves. ${ }^{47}$ Reelected in 1997 for a new six-year term, Ould Taya spared his opponents no pity. The UFD/EN was outlawed in January 2001. The AC's turn came in January 2002 after Ould Boulkheir railed in parliament against the persistence of slavery and criticized the lack of development programmes targeting the Haratine population.

Feeling the brunt of the government's harsh decisions, party leaders began looking for a new framework for action. The creation of a new party, the Convention pour le changement, was refused and it was not until 2003 that the proLibyan Arab nationalists of the Alliance populaire progressiste (APP), an elitist party that was losing momentum, proposed that Messaoud Ould Boulkheir and his Haratine companions join it along with Black Africans. This improbable alliance of usually competing micronationalisms had two consequences. On the one hand, it enabled El-Hor to present itself as a bridge between all the political persuasions in Mauritania and, on the other, it allowed 'Arabists', who automatically became a minority in the party's leadership, to change their ideology and appeal. Messaoud Ould Boulkheir became the APP's president, and El-Hor its driving force.

From 2003 to 2005, the political climate in Mauritania deteriorated. Ould Taya was re-elected president in controversial conditions for a third term in November 2003. Several attempted coups were foiled between June 2003 and August 2004 and Ould Taya was not ousted until 3 August 2005 by Colonel Ely Ould Mohamed Vall and his Comité militaire pour la justice et la démocratie.

\section{The democratic revival and El-Hor's prospects}

After removing Ould Taya, Colonel Ely Ould Mohamed Vall managed an exemplary transition towards democracy by March 2007. A coalition headed by an elected president, Sidi Ould Cheikh Abdellahi, came to power. Messaoud Ould Boulkheir and his party, the APP, held a special place in this coalition. The APP had won only five seats in the 2006 parliamentary elections and did not score well in the presidential elections, winning only $7 \%$ of the votes. Nevertheless, Messaoud Ould Boulkheir unexpectedly decided to endorse Sidi Ould Cheikh Abdellahi during the run-off in the presidential election in exchange for a few ministerial positions for the APP and the speakership in the National Assembly for himself. He also demanded that parliament adopt as its very first text a law criminalizing slavery with sanctions against those guilty of it. In compliance with this pre-election deal, the new government passed a bill

47 Interview with Messaoud Ould Boulkheir, Le Calame, 351, 8 May 2002. 
on 9 August 2007 that made slavery a crime. ${ }^{48}$ The APP immediately held a meeting at which Ould Boulkheir declared, 'After this act, only someone who wants to be a slave will be!'

This controversial statement shocked the leaders of SOS Esclaves, who had actively lobbied for this law against slavery, but with little success. They had failed to amend it and so to allow NGOs to be party to lawsuits about slavery. In fact, during all this, the leadership of SOS Esclaves proved that it was technically competent and endowed with a fighting spirit that only a few of El-Hor's leaders could match. It became obvious that politicians from the Haratine community were no longer the driving force for progress on this hugely symbolic question.

The Haratine social movement was shifting away from politics and political parties and towards advocacy and activism. This remarkable shift mainly affected SOS Esclaves, as my current research on this NGO shows.

\section{From politics to advocacy, the ultimate transformation?}

The development of the activism characteristic of SOS Esclaves represents one of the most important transformations undergone by the Haratine movement. By dramatizing the issue of slavery, this humanitarian human-rights NGO took the campaign back to its roots. Absorbed by politics, El-Hor was no longer the sole standard-bearer of the Haratine cause. SOS Esclaves came into being in February 1995 when, as we have already seen, political protest was more or less stifled due to the vigorous authoritarian restoration. The same process led both to the creation of the AC and underlined the commitment of Boubacar Ould Messaoud, the founding president of SOS Esclaves, to the struggle for human rights in Mauritanian society.

With the support of Messaoud Ould Boulkheir (El-Hor's charismatic leader and moral authority), Boubacar Ould Messaoud, an architect by education and a key figure in the struggle against slavery, wanted to launch a fight distinct from El-Hor's. And with encouragement from various s political sources, he thought an NGO could best broaden the struggle against slavery beyond the category of the Haratine. SOS Esclaves was a suitable name because it expressed a sense of urgency and danger. ${ }^{49}$ The issue of slavery had to be moved out of the constrained game of politics and the intention was to bring together the descendants of masters and of slaves and place the issue on the national agenda.

However this NGO's founding took place amid suspicion and prohibitions. Some of El-Hor's original leaders did not accept this new project, seeing it as a means whereby Boubacar Ould Messaoud would take control of an agenda that

48 Loi n. 2007-048 of 3 September 2007.

49 Interviews with Boubacar Ould Messaoud, May-September 2008, Nouakchott. 
had been jointly drawn up, and orient it in a different direction. As for the government, it was opposed to the new NGO and SOS Esclaves's first press conference was banned. ${ }^{50}$ The only genuinely positive response came from outside the country, where the defence of human rights and the 'actions of civil society' were current catch-phrases.

\section{New methods in a new framework of action}

From the start, SOS Esclaves wanted its actions to be different from the familiar forms of mobilization. A natural action was to update information about clear and indisputable cases of slavery, with the goal being to present names and faces to personify the Haratine problem. The organization helped victims, contacted lawyers to defend them and inveighed against the judicial system's 'complicity'. It undertook and supported court actions and awareness campaigns and, in 1995, it circulated a 'note of information on slavery in Mauritania', which prefigured its annual reports. As of 1996 every report mentioned between thirty and forty cases ranging from servile, unpaid labour to fugitive slaves, land seizures, undue influence in matters of inheritance and separated families whose members were divided among 'masters'. The reports even mentioned acts of kidnapping, illegal restraint, usurpation and physical violence. Some cases were settled through the organization's interventions but the government was usually blamed for its lack of determination to eradicate these phenomena, punish offenders or protect victims in compliance with the many, already enacted, laws and legal measures.

The reports also contained analyses and concrete proposals for eradicating slavery. ${ }^{51}$ It is interesting that the arguments used by SOS Esclaves reformulate the fundamental issues at stake. For them, emancipation does not mean an end to servitude insofar as other sorts of bonds still chain freed slaves to their former masters. Officially freed slaves are even more enslaved if society provides no means of guaranteeing real economic, social and psychological emancipation. $^{52}$

SOS Esclaves owes part of its audience to the suits that the authorities brought against it after French television (FR3) broadcast a documentary about slavery in Mauritania. Boubacar Ould Mesaaoud presented presumed slaves to the cameras and, as a result of this, was arrested, judged and, in early 1998, sentenced to thirteen months imprisonment for 'belonging to an unrecognized association' along with Fatimata Mbaye (a lawyer), Cheikh Saad Bouh Kamara

50 Interviews with Jemal Ould Yessa, September 2008, Dakar/Nouakchott.

51 S.O.S Esclaves (www.sosesclaves.org., March, 2004)

52 Boubacar Messaoud, 'Esclavage en Mauritanie: De l'idéologie du silence la mise en question', Journal des Africanistes, 70, 1 (2000), pp. 291-337. 
(a teacher) and Ibrahim Ould Ebetty (a lawyer). Although the Court of Appeals upheld the sentence on 24 March 1998, the accused were granted remission following pressure from various international organizations. SOS Esclaves gained visibility in the international media.

International backing has in fact always been a strategic point in the organization's support and legitimacy. SOS Esclaves has benefited from its alliance with Conscience et résistance, an organization in exile whose founder and leader, Jemal Ould Yessa, headed the European chapter of SOS Esclaves for a long time. Born into an emir's family in Tagant in central Mauritania, Ould Yessa is very active on the international scene and his support has lent credibility to the organization as he is one of the very few descendants of the Moor nobility to become an activist in an anti-slavery organization. ${ }^{53}$

At the national level, very few Haratine activists have rallied around Boubacar Ould Messaoud, whose personality has strongly marked SOS Esclaves and spurred criticism. For the president of this NGO, activism seems to have become a life-time career and he has repeatedly emphasized that 'Slavery is not a hobby horse but a personal obsession'. ${ }^{54}$ El-Hor's long-time activists seldom join SOS Esclaves, which they see as the business of a comrade who has turned commitment into a solitary fight. Nonetheless, criticism of Ould Messaoud's motivations or sincerity has not stopped the organization from obtaining recognition and registering successes.

\section{Recognition}

The national and international recognition now enjoyed by SOS Esclaves is out of proportion with El-Hor's. The latter has remained an informal organization that has splintered into sub-groups and is deeply involved in politics. It is no accident that, while on a trip to the US in March 2008, the president of SOS Esclaves was asked to speak in the prestigious Woodrow Wilson Center for International Scholars (Washington, DC) and the Open Society Institute (New York). The Washington Post devoted a whole page to him under the headline 'How one brave man helped end slavery in his country'. ${ }^{55}$ In its 2007 report on trafficking in human beings, the US State Department presented Ould Messaoud as one of the world's seventeen 'heroes' working to put an end to modern forms of slavery. ${ }^{56}$ This recognition came but a few weeks after SOS Esclaves was nominated for Anti-Slavery International's 2008 award.

53 Interviews with Jemal Ould Yessa, September/October 2008, Nouakchott/Dakar.

54 Interview with Boubacar Ould Messaoud, Mauritanie-Nouvelles, 235, 23 January 1997 and La Tribune 297, 16 March 2006.

55 Washington Post, 23 March 2008.

56 www.america.gov/st/hrenglish/2008/June/20080604163846ajesrom 
Since 2003 requests from abroad for alternative human-rights reports to those coming from the government have led to SOS Esclaves becoming increasingly indispensable. Under pressure from different international sources, Ould Taya's government was forced to grant it authorization in May 2005 and, as we have seen, SOS Esclaves was, after the military putsch of 3 August 2005 that ousted Ould Taya, associated with policies to extend rights and freedom. Since 2007, its president and its secretary-general have been members of the Commission nationale des Droits de l'Homme (CNDH) that is funded by the government and reports to the prime minister. The CNDH has not only inveighed against the persistence of problems related to slavery but also helped settle several cases. ${ }^{57}$ Ironically, this official commission is chaired by the wellknown and respected Mohamed Said Ould Hamody, a journalist and former ambassador who is none other than the son of the famous Hamody Ould Mahmoud. The latter, who died in 1969, was one of the very few Haratine who made a fortune in the 1940s and 1950s and naturally - like any wealthy man of his day - owned several slaves. ${ }^{58}$

SOS Esclaves may not, however, be the final form of mobilization for the Haratine cause. Groups of this sort are now proliferating and claim to be reviving and radicalizing the cause. Internationally, there is Moctar Teyeb's hyperactivism in the United States. ${ }^{59}$ Claiming to be from El-Hor, he has become associated, under ambiguous circumstances, with an organization called the American Antislavery Group, which is active in Sudan. He even held the title of outreach director in this NGO in 2000 before being heard by the US Senate's Committee on Foreign Relations. ${ }^{60} \mathrm{He}$ set up the Haratine Institute, and persons with similar claims have set up another institute of this sort in France. In Mauritania, young activists, some of them previously from El-Hor or SOS Esclaves, recently created small groups with names such as Conscience haratine or IRA. They are trying to adapt their message to trends in the country or, at least, to advance their personal careers in politics. It is too soon to say anything about their impact or prospects. However they are evidence of the resilience of the Haratine movement and its ability to innovate.

0.3565332.html, June 4, 2008.

57 Commission Nationale des Droits de l'Homme, Rapport Annuel 2007-2008 (CNDH, Nouakchott, June 2008), pp. 21-23.

58 E. Ann McDougall, 'A topsy-turvy world: Slaves and freed slaves in the Mauritanian Adrar, 1910-1950', in S. Miers \& R. Roberts (eds), The End of Slavery in Africa (University of Wisconsin Press, Madison, WI, 2005), pp. 362-390.

59 See the interview with Moctar Teyeb, 'Slavery is a state of mind', Middle East Quarterly, December 1999.

60 William Finnegan, 'A slave in New York: From Africa to the Bronx, one man's long journey to freedom', The New Yorker, 24 January 2000, pp. 50-61. 


\section{Conclusion}

All things considered, the actions taken by the Haratine movement have finally placed the question of improving the situation of the social strata made up of slaves and their descendants on the national political agenda. The movement's itinerary has been deeply shaped over the years by a confluence of factors and shifts of positions in Mauritanian politics. Both El-Hor and SOS Esclaves have played a crucial role in increasing awareness of the cause they defend and have managed to obtain recognition for this social category in politics. Despite its institutional weakness as a result of its emergence as an underground movement, the Haratine movement has been institutionalized by labour unions, political parties and society in general.

Nowadays, there are doubts about whether the Haratine movement is a single cause since ever more diverse actors are now conveying its themes and messages. In addition, the diversified Haratine community has changed independently of the political struggles centred on it. As a consequence, and despite the prestige that El-Hor's founding members enjoy in national politics, it cannot be concluded that they have fully succeeded in creating a 'moral ethnicity' unified around an identity in the pursuit of a common cause. And in spite of the current promotion of the Haratine cause as an outstanding example of a humanrights struggle, these changes are not likely to depoliticize an issue that runs so deep in debates about Mauritania's identity, current situation and prospects. 


\title{
An Islamic social movement in contemporary West Africa: NASFAT of Nigeria'
}

\author{
Benjamin Soares
}

Much recent scholarship about Islam among youth has tended to privilege so-called political Islam or Islamism and the radicalization of Muslim youth. In this chapter, I shift the focus away from such objects of study to consider a new Islamic organization in Nigeria called NASFAT (Nasr Allah al-Fatih Society of Nigeria) that exhibits some features of a social movement. NASFAT also clearly illustrates the influence of Pentecostalism on Muslim religious practice with some even referring to the organization as 'Islamic Pentecostalism'. NASFAT'S founders intended the organization to be both non-sectarian and non-political. Like some other modern Islamic movements, NASFAT has focused on questions of piety and ethics and has been very active in social and economic activities. However, NASFAT's development of business activities, which it has sought to explicitly link with Islam, has been rather distinctive, helping to define it as an Islamic social movement. Given the limited attention to such contemporary Islamic organizations and social movements, which challenge some conventional terms and categories of analysis of Islam, Muslim youth and social movements, the chapter is a preliminary attempt to trace

1 I am most grateful to Professor Amidu Sanni of Lagos State University for introducing me to members of the NASFAT leadership. I am also grateful to Lateef Oladimeji for introducing me to NASFAT members in Abuja and would like to thank Ruth Marshall for her insightful analyses of Pentecostalism and Nigeria that helped me develop some of the ideas discussed in this chapter. Amidu Sanni, Rosalind Hackett, Rüdiger Seesemann, and LaRay Denzer offered useful commentary on earlier drafts. I remain responsible for any deficiencies. 
the history of NASFAT and set it within the larger social and historical context.

Young people - whether considered as a demographic group, a generation or a segment of consumer society - have captured the imagination and, not infrequently, the opprobrium of social and political commentators for several decades now. At least since the Iranian Revolution, there has also been considerable interest in Muslim youth in the world. From the time of the Palestinian intifada when young people were key actors to the events of September 11, 2001 when young Arab hijackers engaged in spectacular acts of terrorism, Islam and especially young Muslims have been key objects of attention and have faced heightened levels of scrutiny. ${ }^{2}$ This degree of interest in young Muslims and their activities is unlikely to abate any time soon.

Given this excessive interest in young Muslims, it is not surprising that much recent scholarship about Islam among youth has tended to privilege so-called political Islam or Islamism and various trajectories of the radicalization of Muslim youth in volatile and unstable settings in the world. ${ }^{3}$ This is not least the case for Nigeria, especially in the predominantly Muslim north of the country where, for several decades, Muslim youth have been prominent religious and political activists. ${ }^{4}$ Since the 1980 s, there have been waves of Muslim radicalism in Nigeria from the millenarian Maitatsine movement to the more recent self-styled Nigerian Taliban. Following the extension of sharia to cover criminal law in twelve northern states beginning in 1999, scholars and other commentators have focused with great intensity on Islam and Muslims in northern Nigeria.

In this chapter, I shift the focus away from such objects of study, which are, of course, not without interest or importance, ${ }^{5}$ to consider a new Islamic orga-

2 See Ted Swedenburg, 'Imagined youths', Middle East Report, 245 (http://www.merip.org/mer/mer245/swedenburg.html, 2007).

3 See, for example, Olivier Roy, Globalised Islam: The search for a new ummah (Hurst, London, 2004); cf. Linda Herrera \& Asef Bayat (eds), Being Young and Muslim (Oxford University Press, Oxford, forthcoming in 2010).

4 See, e.g., Roman Loimeier, Islamic Reform and Political Change in Northern Nigeria (Northwestern University Press, Evanston, IL, 1997); Ousmane Kane, Muslim Modernity in Postcolonial Nigeria: A study of the society for the removal of innovation and reinstatement of tradition (Brill, Leiden, 2003); Murray Last, 'Towards a political history of youth in Muslim Northern Nigeria 1750-2000', in Jon Abbink \& Ineke van Kessel (eds), Vanguard or Vandals: Youth, politics and conflict in Africa (Brill, Leiden, 2005), pp. 37-54; Conerly Casey, 'Marginal Muslims: Politics and the perceptual bounds of Islamic authenticity in northern Nigeria', Africa Today, 54, 3 (2008), pp. 67-92.

5 See Jon Abbink's contribution in this volume. 
nization in Nigeria called NASFAT that exhibits some features of a social movement. As sociologist Charles Kurzman has noted, social movement theorists have until recently largely ignored the Muslim world (with the possible exception of Iran) since social movements defined in relation to Islam generally 'appear to be, and [might even] claim to be, so different from the secular, Western, left-liberal norms that social movement theorists generally espouse' ${ }^{6}$ In turn, scholars of Islam and contemporary Muslim societies have almost completely ignored research on social movements. ${ }^{7}$

I suggest that the study of new Islamic movements and social movement theory could be brought together for mutual benefit. The founders of the new Islamic organization of NASFAT were involved in one of Nigeria's largest and oldest Islamic organizations, which has been an important conduit for Muslim activism and proselytizing as well as occasional radical trends. NASFAT's founders launched an Islamic organization that has become dynamic, influential and perhaps one of the largest in contemporary Nigeria. They intended NASFAT to be both non-sectarian and non-political. Over time and like some other modern Islamic movements, NASFAT has focused on questions of piety and ethics and has been deeply involved in social and economic activities. However, NASFAT's recent development of business activities, which it has sought to explicitly link with Islam, has been rather distinctive, helping to define it as an Islamic social movement. Given the limited attention to these kinds of Islamic organizations and social movements, which clearly challenge some conventional terms and categories of analysis of Islam, Muslim youth and social movements, the following is a preliminary attempt to trace the history of NASFAT and set it within the larger social and historical context.

\section{The context for a new organization}

Nigeria currently has a population estimated at more than 140 million, with many claiming that it is about evenly divided between Christians and Muslims. Some even aver that Muslims might constitute a slight majority. Commentators are nevertheless nearly unanimous in noting the importance of religion in contemporary Nigeria. Numerous reports of Muslim-Christian tensions and conflict

6 Charles Kurzman, 'Conclusion: Social movement theory and Islamic studies' in Quintan Wiktorowicz (ed.), Islamic Activism: A social movement theory approach (Indiana University Press, Bloomington, 2004), pp. 289-303.

7 For notable exceptions, see Quintan Wiktorowicz (ed.), Islamic Activism: A social movement theory approach (Indiana University Press, Bloomington, 2004). None of the contributors, however, considers Sub-Saharan Africa. 
in various parts of the country notwithstanding, ${ }^{8}$ Muslims and Christians have long lived side by side in many places in Nigeria and one can sometimes even find Muslims and Christians within the same family. Some Nigerians have tried to fuse Islam and Christianity, as the name of the religious group 'Chrislam' in the southwest of the country suggests. But such efforts towards religious fusion or synthesis seem to be rather exceptional and increasingly so. In many places, there has been intense competition and higher levels of tension within and between different confessional groups. Given the mutual demonization by certain Christians and Muslims in Nigeria in recent years, such competition and tensions contribute to what Murray Last has called 'an economy of panic' that has been rather volatile. ${ }^{9}$

The 1970s oil boom, the subsequent massive investments in education, the unprecedented spread of the mass media and increased urbanization have all had a profound effect on Nigerian society and the practice of religion in particular. Although political liberalization came relatively late to Nigeria in the late 1990s, Muslim and Christian associational life flourished under the long periods of repressive military rule. While there has been considerable research on recent Christian developments in the country and in the historically Muslim north, particularly in the major urban centre of Kano, there has been much less research on Muslims living outside northern Nigeria. ${ }^{10}$

The new Muslim organization founded in 1995 is known as NASFAT; ${ }^{11}$ an acronym of the Arabic portion of the organization's full name, Nasr Allah alFatih Society of Nigeria. Nasr Allah means literally 'the help of God' and is a phrase that occurs several times in the Qur'an. ${ }^{12}$ Al-Fatih, means 'the victorious'. The entire phrase in Arabic could be translated into English as 'the help of

8 See Toyin Falola, Violence in Nigeria: The crisis of religious politics and secular ideologies (University of Rochester Press, Rochester, NY, 1998); Rosalind I.J. Hackett, 'Managing or manipulating religious conflict in the Nigerian media', in Jolyon Mitchell \& Sophia Marriage (eds), Mediating Religion: Conversations in media, religion and culture (T. \& T. Clark, Edinburgh, 2003), pp. 47-64; Murray Last, 'Muslims and Christians in Nigeria: An economy of political panic', The Round Table: The Commonwealth Journal of International Affairs, 96, 392 (2007), pp. 605-616; Adam Higazi, 'Violence urbaine et politique à Jos (Nigeria), de la période coloniale aux élections de 2007', Politique africaine, 106 (2007), pp. 69-91.

9 Murray Last, 'Muslims and Christians in Nigeria'.

10 There has also been little research on Muslim-Christian relations in Africa more generally. See Benjamin F. Soares (ed.), Muslim-Christian encounters in Africa (Brill, Leiden, 2006).

11 See Amidu Sanni's brief discussion of NASFAT in Amidu Sanni, 'Challenges and realities in the healing and power accession custom of the Yoruba Muslims of Nigeria', Journal of Oriental and African Studies, 15 (2006), pp. 145-156.

12 It occurs in sura 10 of the Quran, which most commentators agree refers to the surrender of Mecca to Muhammad. 
God is victorious'. However, in NASFAT's print media it is translated as 'there is no help except from Allah'.

It is useful to think of this new Islamic organization as a social movement and a specifically Islamic social movement, which can only be understood within Nigeria's plural and complex religious landscape and in relation to some of the socio-economic changes over the past two decades. The organization-cumsocial-movement NASFAT was founded away from the historically Muslim northern part of Nigeria in the religiously plural southwestern region of the country that today is called Yorubaland. Southwestern Nigeria is a region where Muslims, Christians and practitioners of African traditional religions have lived together since the nineteenth century with the rise of Christianity. During that period, Christianity and Islam spread simultaneously. ${ }^{13}$ Over time, Muslims, Christians and practitioners of African traditional religion - so-called Yoruba religion in this particular setting - have borrowed and appropriated from each other in ways that have invited admiration or scorn depending on one's perspective. Although Yoruba religion ${ }^{14}$ and Christianity are both well-developed fields of study, Islam among the Yoruba - half of whom are estimated to be Muslims - remains curiously understudied. ${ }^{15}$

While the boundaries between different religious groups in southwestern Nigeria have been shifting and unstable over time, there are several important developments in relation to which NASFAT's rise must be understood. First, given the religiously plural landscape of southwestern Nigeria, Muslims from elsewhere in the country along with some Yoruba Muslims have at times disparaged the practice of Islam in Yorubaland as less 'pure' than elsewhere, more prone to 'mixing' with non- or un-Islamic elements, and so forth. For example, Muslims in northern Nigeria make constant reference to the nineteenth century - the jihad led by Uthman dan Fodio with his allegedly unwavering commitment to extirpate the un-Islamic and the polity, the Sokoto Caliphate that ensued

13 See J.D.Y. Peel, 'The pastor and the babalawo: The interaction of religions in nineteenth-century Yorubaland', Africa, 60, 3 (1990), pp. 338-369; Ibid., Religious Encounter and the Making of the Yoruba (Indiana University Press, Bloomington, 2000).

14 For some of the most recent studies of Yoruba religion, see Jacob K. Olupona \& Terry Rey (eds), Orisa Devotion as World Religion: The globalization of Yoruba religious culture (University of Wisconsin Press, Madison, 2008).

15 For exceptions, see T.G.O. Gbadamosi, Growth of Islam among the Yoruba, 18411908 (Longman, London, 1978); Patrick J. Ryan, Imale: Yoruba participation in the Muslim tradition, a study of clerical piety (Scholars Press, Missoula, MT, 1978); and H.O. Danmole, 'Religious encounter in southwestern Nigeria: The domestication of Islam among the Yoruba', in Jacob K. Olupona \& Terry Rey (eds), Orisa Devotion as World Religion: The globalization of Yoruba religious culture (University of Wisconsin Press, Madison, 2008), pp. 202-220. 
- when they talk about Islam and being Muslim today. And many Nigerian Muslims think that Uthman dan Fodio and his legacy (however it may be interpreted) should be the model applied across the board, also in places such as Yorubaland. But Islam has been present for a very long time in southwestern Nigeria and many Muslims there, including many Yoruba, are proud and not infrequently defensive of their religious traditions. They are also sometimes resentful that Muslims from elsewhere would deign to impose a model on them or denigrate the way they practise Islam. Be that as it may, many Muslims in southwestern Nigeria have been at the forefront of efforts to change or 'reform' the practice of Islam from within their own communities. As Stefan Reichmuth has observed, 'many educated Yoruba Muslims have been striving [especially] since the seventies to establish distinctly Islamic patterns of personal and communal life'. ${ }^{16}$ Many Yoruba Muslims have wanted to affirm Islam and being Muslim. In doing so, they have frequently sought to distance themselves from Yoruba 'traditional' religion, as well as the Christianity of Christian Yoruba, many of whose followers embraced and benefited from Western education much earlier than Muslims.

Second, in recent years the rapid rise and spread of Pentecostalism in Nigeria and its increased presence in the public sphere have fundamentally altered the country's religious landscape. As we know from the work of various scholars, ${ }^{17}$ Pentecostalism has drawn many people in southwestern Nigeria away from the mainline Protestant churches, the Roman Catholic Church as well as from African independent churches. Muslims in southwestern Nigeria have been in constant contact with Pentecostalism, which now saturates public life. Many, particularly young Muslims, have been attracted to Pentecostal services and activities with their lively worship, leadership roles and the health and wealth gospel. The appeal of Pentecostalism makes quite a number of Nigerian Muslims uneasy. In some ways, one could speak about the pentecostalization of Christianity in Nigeria. Other Christian churches, including the Roman Catholic Church, have revitalized their own charismatic traditions and appropriated Pentecostal styles and techniques to various degrees. This is also the case for some Muslims in Nigeria. Many Nigerians - Muslims and Christians alike - actually

16 See Stefan Reichmuth, 'Education and the growth of religious associations among Yoruba Muslims: the Ansar-Ud-Deen Society of Nigeria', Journal of Religion in Africa, 26, 4 (1996), pp. 365-405, quoted on p. 387.

17 See Ruth Marshall-Fratani, 'Mediating the global and the local in Nigerian Pentecostalism', Journal of Religion in Africa, 28 (1998), pp. 278-315; Rosalind I.J. Hackett, 'Radical Christian revivalism in Nigeria and Ghana: Recent patterns of conflict and intolerance', in Abdullahi A. An-Na'im (ed.), Proselytization and Communal Self-Determination in Africa (Orbis Books, Maryknoll, NY, 1999), pp. 246267. 
refer to organizations like NASFAT (sometimes with derision) as 'Pentecostal Islam' or 'Islamic Pentecostalism' and its members as 'Born-Again Muslims', and NASFAT helps to illustrate quite clearly some of the influence of Pentecostalism on Muslims, their religious practices and organizations.

\section{Beginnings and raison d'être}

In 1995 a group of ten young Yoruba men founded NASFAT, which they had originally conceived of as a prayer group for Muslim men who regularly met to pray together. In the following year, they decided to incorporate NASFAT as a formal organization. It is important to note that only one of the original founders, Abdullah Akinbode (b. 1957), seems to have had any formal, advanced Islamic religious training, or what we might call Islamic scholarly credentials. He obtained a BA in Islamic Studies from the University of Lagos (UNILAG), the massive state university in Lagos, Nigeria's most important economic centre and possibly its largest city, and then subsequently went on to complete MA studies in international law and diplomacy there too. Like Akinbode, the other founders of NASFAT were also Yoruba Muslims and university graduates and were all professionals working in banking and other modern sectors of the economy.

It is striking how NASFAT's founders are sociologically quite similar to some of the other new Muslim intellectuals ${ }^{18}$ elsewhere in Africa and further afield in the Muslim world whose educational training in modern subjects often sets them apart from existing Muslim scholars - the 'ulama - whose classical training is frequently restricted to traditional religious subjects, curricula and methods. ${ }^{19}$ However, unlike the lumpenintelligentsia, Olivier Roy's rather disparaging moniker for some of the new Muslim intellectuals in the world today, the group of Yoruba Muslims who founded NASFAT were either solidly mid-

18 On new Muslim intellectuals, see René Otayek, 'Introduction: des nouveaux intellectuels musulmans d'Afrique noire', in René Otayek (ed.), Le radicalisme islamique au sud du Sahara: Da'wa, arabisation et critique de l'Occident (Karthala, Paris, 1993), pp. 8-18; Olivier Roy, The Failure of Political Islam, Trans. C. Volk (Harvard University Press, Cambridge, MA, 1994).

19 There have been many important transformations in 'traditional' Islamic education in Nigeria that are beyond the scope of this chapter. See, for example, Stefan Reichmuth, 'The modernization of Islamic education: Islamic learning and its interaction with "Western" education in Ilorin, Nigeria', in Louis Brenner (ed.), Muslim Identity and Social Change in Sub-Saharan Africa (Indiana University Press, Bloomington, 1993), pp. 179-197; Muhammad Sani Umar, 'Education and Islamic trends in Northern Nigeria: 1970s-1990s', Africa Today, 48, 2 (2001), pp. 127-150; Ibid., 'Profiles of new Islamic schools in Northern Nigeria', The Maghreb Review, 28, 2-3 (2003), pp. 145-169. 
dle class or, like most Western-style educated Nigerians and regardless of their religious background, aspired to the kind of middle-class lifestyle for which their modern Western-style university education prepared them, and to which they usually felt entitled.

With the serious economic decline following the fall in oil prices in the 1980 s, the failure of the developmentalist model of the state and the further economic downtown during the years of chaotic military rule in 1990s, many Nigerians yearned for some semblance of normality and prosperity. Ruth Marshall has argued that 'Pentecostalism and new Islamic movements ... [have] pose[d] one of the greatest threats ever to its [the Nigerian state's] goal of national unity and ideologies of development'. ${ }^{20}$ Islamic movements such as NASFAT (like Pentecostalism) have certainly become much more visible in the Nigerian public sphere. As the state has cut back on or stopped providing certain services, some religious organizations have stepped in to provide key services in the areas of health, social welfare, education and even security. ${ }^{21}$ Rather than posing any kind of threat to national unity or even to state-promulgated ideologies of development, NASFAT has not only assisted in providing some of the much-needed and desired social services (see below) but has also helped to nurture and sustain ideologies of development and promote ideals of national unity.

Abdullah Akinbode, the one founder with Islamic scholarly credentials, who now has the title of NASFAT's 'Chief Missioner' and is the general overseer of the organization's activities, has explained that he and his friends wanted to found a new organization that met their own needs after leaving university. While they were students, they had been active in the Muslim Students' Society (MSS) of Nigeria, the major Muslim students' group that Yoruba Muslims founded in the 1950s. It subsequently spread to university campuses throughout the country and, in the process, students helped to transform the MSS into a national Muslim students' association, thereby shedding any identification solely with the Yoruba. Various Muslim activist groups have emerged from the MSS, including the Muslim Brothers, a large group that sought inspiration from the Iranian Revolution to transform Nigerian society, as well as various other groups that have splintered from the Muslim Brothers. ${ }^{22}$

20 See Marshall-Fratani, 'Mediating the global and the local in Nigerian Pentecostalism', p. 282.

21 For case studies of such processes among Muslims in Africa, see Benjamin F. Soares \& René Otayek (eds), Islam and Muslim Politics in Africa (Palgrave Macmillan, New York, 2007).

22 On the MSS, see Stefan Reichmuth, Islamische Bildung und soziale Integration in Ilorin (Nigeria) seit ca. 1800 (LIT Verlag, Münster, 1998). Although the history of 
The founders of NASFAT have stated that they wanted to found a modern organization that specifically addressed the needs and interests of Muslim youth. In a recent interview with a Nigerian journalist, Akinbode explained:

At a point, we realised that it is not always easy for young people to comfortably be with older people with their peculiar ideas. I for one, cannot be in the same group with somebody who is 60,70 or even 80 years old and you want me to be saying no to certain things he wants to do. He is used to the old fashion. The best thing for me is to come out of those societies and form my own with people who share the same values as me so that I will not be disrespectful to the elders. I will have more affinity with people of like minds and without condemning what the elders are doing we can carry on with our own ways. It is more of a way of conforming to modernity without losing trend with the dictates of Islam. ${ }^{23}$

As this clearly indicates, Akinbode and his peers saw their elders as being out of step with modernity. They were actively seeking a way to reconcile Islam and being Muslim with the modern society - frenetic, urban southwestern Nigeria - in which they were living. In founding a new Islamic organization, they were actually following the well-trodden path taken by many Muslims in this part of the country. There are many existing Islamic organizations in Nigeria, including the large and diverse modernist Islamic educational institutions and organizations that usually promote Western education, which have been active in Yorubaland since the first half of the twentieth century. Such organizations include the modernist Ansar-Ud-Deen Society of Nigeria ('Helpers of the Religion' Society) founded in Lagos in the $1920 \mathrm{~s}^{24}$ and Anwar-Ul-Islam ('The Lights of Islam'), an organization for members of the Indian Ahmadiyya sect, which has been around in West Africa since the first decades of the twentieth century. ${ }^{25}$ Like its predecessors, NASFAT was also a new organization that targeted, at least initially, Muslim youth who fashioned themselves as modern, aspiring to achieve what NASFAT considers 'conformity with modernity'. Unlike those Nigerians of a more uncompromising 'maximalist' or radical bent, ${ }^{26}$ they aim not to be 'disrespectful' of their elders. In other words, they try not to

these other Islamic organizations in Nigeria remains to be written, see the references in note 4

23 Ernest Omoarelojie, 'Why NASFAT is growing', The News

(http://thenewsng.com/interview/why-nasfat-is-growing/2009/02, February 9, 2009).

24 See Reichmuth, 'Education and the growth of religious associations among Yoruba Muslims'.

25 Although the study of the Ahmadiyya in Africa remains to be written, see Humphrey Fisher, The Ahmadiyya: A study in contemporary Islam on the West African coast (Oxford University Press for the Nigerian Institute of Social and Economic Research, London, 1963).

26 On 'maximalist' styles of religion, see Bruce Lincoln, Holy Terrors: Thinking about religion after September 11 (University of Chicago Press, Chicago, 2003). 
publicly condemn or malign elders whose views and practices they might not like. Moreover, unlike more radical Muslim (and also some Christian) individuals, groups and organizations, NASFAT does not expect its members to reject or anathematize fellow Muslims who do not share their views. ${ }^{27}$ In fact, some of NASFAT's officially stated 'moral imperatives' and 'shared values' include 'being caring, humane and tolerant' towards others. NASFAT members are enjoined to 'protect human dignity, and maintain and uphold the human rights of all persons' and 'respect the diversity of all cultures and religions' ${ }^{28}$ Such ideas about tolerance, human rights and respect for cultural and religious diversity are clearly unlike some of the Pentecostal and Islamic discourse in Nigeria that displays a marked tendency to demonize the religious other as well as African traditional religion and its practitioners.

At the same time, NASFAT's founders have emphasized how they wanted to found an Islamic organization that was non-hierarchical in nature. Today, its leaders and publications note that they want to avoid practices such as 'heroworship' and 'ostentation', which they claim 'can hinder the attainment of our collective aspirations' ${ }^{29}$ Given Nigeria's reputation - indeed notoriety - for its 'big men' with their great wealth (however amassed), lavish lifestyles and coterie of clients, not to mention rampant and often brazen corruption, it is perhaps not surprising to see members of a new religious organization such as NASFAT rejecting the 'worship' of such persons and their public ostentation, as well as warning of the dangers and temptations of corruption. This eschewing of ostentation (and, by extension, corruption) is not unlike the rejection of materialism associated with Pentecostalism in earlier periods in Nigeria. ${ }^{30}$ One might also read it as an overt rejection of the ostentation associated with the so-called gospel of prosperity and public displays of excessive consumption that have recently spread among Pentecostals in Nigeria and elsewhere. As already noted, NASFAT was founded at a time when the Pentecostal presence in the public sphere was increasingly pronounced. Moreover, Pentecostals' extensive use of mass media and their organizational acumen have helped to infuse urban land-

27 This is one reason why it would be not only imprecise but also misleading to call NASFAT 'fundamentalist' as some have. See, for example, Kate Meagher, 'Manufacturing disorder: Liberalization, informal enterprise and economic "ungovernance" in African small firm clusters', Development and Change, 38, 3 (2007), pp. 473-503.

28 These themes are repeated in NASFAT's promotional materials. See also NASFAT's Code of Conduct (NASFAT Society, Lagos, 2005).

29 I have heard NASFAT members and leaders make such statements. The quotations are from the webpage 'About NASFAT', on NASFAT Nigeria's website (http://www.nasfat.org/about.php). See also NASFAT's Code of Conduct (NASFAT Society, Lagos, 2005).

30 See Marshall-Fratani, 'Mediating the global and the local in Nigerian Pentecostalism'. 
scapes with their presence. ${ }^{31}$ Many young Muslims have been exposed to and, without necessarily 'converting', have participated in the ostentatious activities of Pentecostals that have helped to index their success.

It is noteworthy, however, how NASFAT's stated aversion to ostentation and so-called hero-worship is also directed in part towards existing Islamic religious practices and Muslim religious leaders, some of whom have earned a reputation for ostentation and conspicuous consumption. In launching NASFAT, its founders were consciously seeking to distance their organization from the Sufi orders, which have long had a prominent place in Nigeria and in the southwestern part of the country in particular. ${ }^{32}$ In general, Sufi orders are organizations that are premised on a hierarchy along with the notion that certain Muslims - often called saints - are closer or have special access to God and his favour. Ordinary Muslims frequently take the founder of a Sufi order or a branch of such an order, his descendants and/or deputies as potential intermediaries with God or as possessors of special, secret knowledge. Many Muslims treat Sufi leaders with great respect and accord them all sorts of privileges, including considerable material resources. Indeed, this is the case for the Tijaniyya, including the branch of the Tijaniyya in Africa propagated by Ibrahima Niasse (d. 1975), who hailed from Kaolack in Senegal. Ibrahima Niasse's branch of the Tijaniyya - variously called the Tijaniyya Niassène or the Ibrahimiyya - has been the most prominent branch of the Tijaniyya in Nigeria, including southwestern Nigeria, and in Africa more generally for decades. Critics of the Sufi orders and the Tijaniyya in particular frequently condemn those involved in Sufi orders of encouraging 'saint-worship', which they explicitly equate with 'hero-worship'. Such hero-worship is precisely what NASFAT states it would like to avoid in its modern version of Islam.

In contrast to Sufi-informed ideas about religious hierarchy, the presumed need to defer to others higher up in such a hierarchy, and the special training one ostensibly requires from a Sufi master to advance within the hierarchy, NASFAT's founders explicitly talk about the 'equality of all Muslims' or at least the potential equality of all Muslims. ${ }^{33}$ This emphasis on the equality of all Muslims would seem to be an attempt to downplay potential differences between Muslims, whether linguistic, ethnic, regional or sectarian. Such differen-

31 See Ibid.; Hackett, 'Radical Christian revivalism in Nigeria and Ghana'.

32 See, for example, Abner Cohen's classic study of Hausa migrants in southwestern Nigeria. Abner Cohen, Custom and Politics in Urban Africa: a study of Hausa migrants in Yoruba towns (Routledge \& Kegan Paul, London, 1969).

33 This theme recurs in much of the NASFAT literature and on the NASFAT Nigeria website. It is noteworthy that there is no explicit rejection of Sufism or Sufi orders in NASFAT's literature. 
ces have sometimes been key factors in various intra-Muslim debates and conflicts that have played out in the country. ${ }^{34}$

Taken together, the challenge to existing religious hierarchies, the implicit rejection of Sufi orders, the assertion of the equality of all Muslims and the rejection of ostentation, along with its ideas about rights and respect, illustrate how NASFAT as an organization is advocating modernist and reformist views of Islam. Such views have become increasingly popular throughout the Muslim world, including elsewhere in Africa. However as Roman Loimeier has argued, local and regional contexts invariably influence modernist and reformist positions and their development over time. ${ }^{35}$ Indeed, the form that such modernism and reformism has taken bears the imprint of the Nigerian context and southwestern Nigeria in particular. In many places in the contemporary world, modernist and reformist Muslims are vehemently opposed to celebrations of the mawlid, the birthday of the Prophet Muhammad. Reformists usually argue that such practices are not Islamic. In their way of thinking, they are unlawful innovations that diverge from correct Islamic practice (Arabic: bid'a). This is, for example, the perspective of the massive Nigerian reformist Islamic organization, the Society for the Removal of Innovation and Reinstatement of Tradition, better known as Izala, which has been particularly active in northern Nigeria. Interestingly, NASFAT, unlike other organizations such as Izala, is not explicitly opposed to celebrations of the mawlid. In fact, like Sufi orders in Nigeria and elsewhere, NASFAT actually organizes gatherings for communal prayer during the mawlid where speakers emphasize the Prophet Muhammad and his exemplary life, which, they claim, all Muslims should strive to emulate in their own lives.

Much like the Sufi orders and other modernist and reformist organizations, NASFAT places great emphasis on piety and the correct practice of Islam. In contrast to the Sufi orders, there are no special, secret practices for initiates. NASFAT considers all Muslims as equal and therefore potentially perfectible. Each individual NASFAT member is enjoined to adhere to 'the Holy Qur'an and the sunnah', that is, the traditions of Prophet Muhammad. Although this is stated to be a collective endeavour for the organization's members, in practice it is a form of personal piety that is incumbent upon individual members. Indeed, it takes the form of individual obligations to apply Islam in one's life and by extension to encourage those around one to do the same. Such Islamization

34 This is an area that requires much more research. See, for example, Murray Last, 'Muslims and Christians in Nigeria: An economy of political panic'; Susan O'Brien, 'La charia contestée: Démocratie, débat et diversité; musulmane dans les "États charia” du Nigeria', Politique africaine, 106 (2007), pp. 46-68.

35 Roman Loimeier, 'Patterns and peculiarities of Islamic reform in Africa', Journal of Religion in Africa, 33, 3 (2003), pp. 237-262. 
'from below' contrasts sharply with efforts to impose Islam from above as, for example, in the so-called sharia states in northern Nigeria and other self-styled Islamic states around the world. Although the individual Muslim is a key focus of NASFAT, being a member of the organization is also important, an issue to which we now turn.

\section{Membership and activities}

Several commentators, including the NASFAT leadership, readily point out that NASFAT's membership is largely comprised of members of the elite, including well-educated Muslims who are professionals, business leaders, government officials, doctors, lawyers and engineers. ${ }^{36}$ This might even be the impression one has if one attends, for example, NASFAT services in Abuja, the federal capital of Nigeria where one can encounter many middle-class professionals, businessmen, civil servants working in government ministries and educators in attendance. However, in other places where I have attended NASFAT meetings, for example in neighbourhoods of Lagos, members and attendees clearly come from a wider array of socio-economic backgrounds.

Today, NASFAT claims more than one million members in Nigeria in more than 180 chapters throughout the country but also abroad in such places as Atlanta, Houston, London, Seville and The Hague. ${ }^{37}$ Since NASFAT's founding, dense networks of relations have developed between members of the organization. Although NASFAT has spread rapidly and widely since it was founded in the mid-1990s, ${ }^{38}$ it remains very much a Yoruba Muslim organization, arguably even a form of Yoruba Muslim cultural nationalism. It can be found anywhere where there are large concentrations of Yoruba in Nigeria and in the diaspora, and most members seem to be Yoruba. The Yoruba focus of the NASFAT is evident in some of the organization's publications, for example, its official prayer book that contains prayers in Arabic, presented in Latin transliteration alongside Yoruba translations. No African languages other than Yoruba seem to be used in NASFAT's official publications.

In some ways, NASFAT has become a veritable social movement though perhaps not as conventionally understood in social movement theory. Given the secular and Western orientation of most social movements' theorizing, Islamic social movements with their anti-secular and sometimes outright illiberal goals

36 See Ernest Omoarelojie, 'Why NASFAT is growing'.

37 A list of chapters is available on the NASFAT website (www.nasfat.org).

38 A splinter group, led by the organization's first chief missioner, broke away from NASFAT and founded Al-Fatih Ul-Quareeb Islamic Society of Nigeria, and another organization emerged in turn from that organization. Such developments are beyond the scope of this chapter. 
have been difficult to incorporate into such theory and therefore have usually been ignored. While not espousing explicitly illiberal goals, NASFAT nevertheless challenges the secular and Western biases of social movement theory with its restrictive understanding of what might constitute a social movement and the goals and objectives of group social action.

It is striking that NASFAT has goals and objectives that are at once modest and yet far-reaching. NASFAT's promotional materials repeatedly stress that the organization intends to be 'pace-setting'. Its stated mission is: 'To develop an enlightened Muslim Society nurtured by a true understanding of Islam for the spiritual upliftment and welfare of mankind'. ${ }^{39}$ According to Nigerian observers of NASFAT, the organization appears to have no distinct creed or doctrine and, in fact, seems to advocate what Dale Eickelman has called a 'generic' Islam of universals - prayer, fasting, charity and so forth. ${ }^{40}$ This generic Islam is compatible with modernity and living in a society in which there has been incredible political, social and economic uncertainty over the past few decades. It almost seems to follow that the organization focuses considerable attention on promoting its code of conduct, ethics and lifestyle. In this way, NASFAT is in keeping with some wider trends in the Muslim world where many Muslims have been increasingly concerned with questions about ethics and piety. ${ }^{41}$

NASFAT is involved in activities that are ostensibly a means to reach the goal of 'an enlightened Muslim society'. These activities include $d a$ 'wa (Arabic), that is, the call or invitation to Islam, including instruction in the basics of Islam (prayer, fasting during Ramadan, the paying of alms or tithing, etc.), Islamic educational and Arabic language classes for children and adults, and allnight prayer sessions (which are also associated with Sufi orders and Pentecostalism). There is nothing particularly unusual about any of these religious activities for the promotion of a generic Islam of assumed universals, not least for a modern Islamic organization or Islamic movement beginning with the Muslim Brotherhood founded in Egypt in the 1920s. Indeed, such religious activities are a good illustration of Islamization 'from below'. It is also not out

39 The quotes are from 'Profile' (n.p., n.d.), a glossy promotional flyer obtained from the NASFAT World Headquarters in Ilupeju, Ikeja in January 2008. On Yoruba conceptions of enlightenment and related ideas, see J.D.Y. Peel, 'Olaju: A Yoruba concept of development', The Journal of Development Studies, 14 (1978), pp. 135165.

40 Dale F. Eickelman, 'National identity and religious discourse in contemporary Oman', International Journal of Islamic and Arabic Studies, 6, 1 (1989), pp. 1-20.

41 Cf. Roy, Globalised Islam; René Otayek \& Benjamin F. Soares, 'Introduction: Islam and Muslim politics in Africa', in Benjamin F. Soares \& René Otayek (eds), Islam and Muslim Politics in Africa (Palgrave Macmillan, New York, 2007); Benjamin Soares \& Filippo Osella, 'Islam, politics, anthropology', Journal of the Royal Anthropological Institute (N.S.), 15, S1 (2009), pp. 1-23. 
of the ordinary that NASFAT's $d a$ 'wa activities are on the whole specifically geared towards other Muslims. In other words, $d a$ ' $w a$ activities do not appear to target Christians but are undoubtedly aimed at those Muslims who might be interested in Pentecostalism and might even convert from Islam to Christianity. As mentioned earlier, some Yoruba Muslims worry about the exposure of fellow Muslims to Pentecostalism.

In addition to such religious activities with the ultimate goal of 'spiritual upliftment and [the] welfare of mankind', in NASFAT's way of thinking da' $w a$ is also felt to encompass economic empowerment. In fact, one of the organization's explicitly stated and oft-repeated 'strategic objectives' is 'to promote [the] economic empowerment of our members' ${ }^{42}$ Such economic objectives are somewhat unusual for an Islamic organization, and especially for an Islamic social movement in the Nigerian context. However, it is not unlike the trend towards what some have called 'market Islam' in places such as Indonesia where Muslims are enjoined to discipline themselves in accordance with the demands of the market in neoliberal capitalism. ${ }^{43}$ In an official NASFAT publication, 'economic empowerment' is actually listed second - after 'recitation of a prayer book' - in a list of da'wa activities. The $d a$ ' $w a$ activities around economic empowerment actually come in the list prior to 'usrah [Arabic: family] classes' where the 'basic fundamental of Islaam [sic] are discussed on a weekly basis'. ${ }^{44}$ Commenting on Nigeria's economic problems, NASFAT indicated that 'Due to [the] high rate of joblessness among Muslims, our secretariat [NASFAT] took it upon itself to source for employment vacancies from various companies for members and Muslims in general'. ${ }^{45}$ It seems that economic empowerment comes prior to and is imperative for spiritual 'upliftment' and general welfare. In this way, NASFAT explicitly links economics with questions of ethics. Despite its reputation for having many well-connected and welleducated members with good, well-paid jobs, the vast majority of NASFAT's current members in Nigeria seem to be, like many Nigerians, facing daunting economic obstacles and high levels of insecurity. However, NASFAT seems to hold out the promise to its members that individual ethical reform and economic empowerment go hand in hand.

42 'Profile' (n.p., n.d.).

43 Cf. Daromir Rudnyckyj, 'Market Islam in Indonesia', Journal of the Royal Anthropological Institute (N.S.), 15, S1 (2009), pp. 182-200, and Patrick Haenni, Islam de marché: L'autre révolution conservatrice (Seuil, Paris, 2005).

44 'Profile of Nasrul-lahi-l-Fathi Society' (n.p., n.d.), a four-page document printed on NASFAT letterhead, obtained from the NASFAT World Headquarters in Ilupeju, Ikeja in January 2008.

45 Ibid. 
What makes NASFAT somewhat atypical at least as an Islamic organization in the broader Nigerian context is its active involvement in social welfare and health-related activities. In addition to the free medical services that it provides its members, NASFAT also organizes regular health initiatives - for example, blood-pressure monitoring and diabetes tests - that its members need and want. NASFAT is also known as a venue for people to deal with 'spiritual afflictions', to use the Nigerian language for spiritual insecurity and crises, which might be as much socio-economic as individual. Members are cautioned against resorting to 'magical practices', 'occult knowledge', sorcery and charms. While this is similar to widespread Pentecostal discourse in Nigeria, NASFAT articulates such warnings less vehemently than Pentecostals, for whom these practices are a major preoccupation. Instead of using 'magical practices', members are encouraged to engage in prayer and modern health-seeking behaviour via the services NASFAT provides. ${ }^{46}$ It also organizes vocational training for its members, as well as marriage counselling services. Like many other religious organizations in Nigeria, NASFAT is thus involved in realms - such as health, and social and economic welfare - that transcend the narrowly religious.

One feature that certainly distinguishes NASFAT from other Islamic organizations in Nigeria and other Islamic social movements is the active and serious business plan that its leaders and promotional materials frequently highlight. Such plans have evolved over time and the organization has recently started to engage in large-scale income-generating activities. According to Akinbode:

But the bottom line is that we don't want to be stereotypical by doing things the old fashioned way. We don't want to go cap in hand as we did before for alms. The alms we are collecting could be invested and with the profit we make from it we can do certain other things. That is why we took the option of going into business. ${ }^{47}$

Here, Akinbode is pointing to the insufficiency of relying solely on the compulsory alms (Arabic: zakat) that Muslims are supposed to give and the need for active investments that generate profits for reinvestment in the organization. Massive numbers of Nigerian Muslims perform the hajj every year, and NASFAT has launched a travel agency, Tafsan (NASFAT spelled backwards), that arranges travel for the pilgrimage. Aside from providing such potentially profitable services that are specifically religious, NASFAT also produces and markets a non-alcoholic malt beverage, Nasmalt, the profits from which are destined for da'wa, which includes economic empowerment. In accordance with the ban in Islamic jurisprudence on charging interest on loans, NASFAT had a cooperative bank that was subsequently transformed into a community

46 These references to magic and the occult come from NASFAT's Code of Conduct (NASFAT Society, Lagos, 2005).

47 Ernest Omoarelojie, 'Why NASFAT is growing'. 
bank, Tafsan. With more than 150,000 depositors, Tafsan Community Bank offers interest-free loans. ${ }^{48}$ There is a potentially large and lucrative market among Muslims in Nigeria for such Islamic banking services. NASFAT has also recently founded its own university, Fountain University, a name that does not clearly index that it is Islamic. The university, just one of many in the burgeoning private educational sphere amid public-sector educational decline, is located in Osogbo in Osun State and has recently received accreditation from the Nigerian government.

Central to all of NASFAT's business plans has been a sophisticated marketing plan that has helped to turn NASFAT into a known brand, recognizable in the crowded religious and media landscapes in southwestern Nigeria. Over the past few years, the branding and extensive marketing that NASFAT has developed has been a key element in its success in gaining public recognition. The branding of NASFAT includes a stylized logo with the NASFAT acronym in black typeface and the Islamic star and crescent motif in green. This appears on nearly everything NASFAT produces, distributes and sells. The NASFAT logo is becoming ubiquitous and is prominently placed on all media associated with the organization, as well as on all of the organization's promotional materials, signboards, posters, newspaper columns, bumper stickers, books, pamphlets, clothing, caps, key chains and handkerchiefs. Although the commercially marketed and profit-seeking venture Nasmalt beverage, Tafsan Tours \& Travels and Fountain University do not feature the NASFAT logo, they often appear alongside the NASFAT logo in NASFAT promotional materials. The branding of NASFAT seems to be so important - and potentially profitable - that improper use of the brand and logo is clearly spelled out in NASFAT's 2005 Code of Conduct.

To accommodate the busy work schedules of most Nigerian Muslims and to compete with or offer an alternative to church services, NASFAT holds weekly meetings on Sundays. This is of course quite unusual for a Muslim group since most Muslims gather for communal prayers at midday on Fridays. Although there are other Muslim organizations in Nigeria (e.g. Al-Usrah based in Port Harcourt) that also hold Sunday-morning services, NASFAT seems to be the largest Muslim organization to do so. Like their Christian neighbours, NASFAT members also meet on Sunday mornings. The children learn the Qur'an while the adults listen to sermons and recite praise of the Prophet Muhammad, with their Sunday worship culminating in a communal prayer (salat). The weekly meetings also include prayer requests and testimonials, which are not ordinarily associated with Muslim religious activities and public worship in particular. After the communal prayer, people return home for Sunday lunch. NASFAT

48 ، Profile of Nasrul-lahi-1-Fathi Society’ (n.p., n.d.). 
members are enjoined to wear white garments at the weekly services, something reminiscent of the hajj where people are required to wear white, showing that all Muslims are equal. However their white clothing looks similar to the 'white garment' worn by members of some African independent churches in Nigeria, and many Nigerians readily point this out. Those attending NASFAT services dressed all in white are, nevertheless, clearly distinct from many Nigerian Christians (men and women) who take great care to dress up in their finest clothes for church services at mainline Protestant, Pentecostal and Roman Catholic churches.

It is perhaps NASFAT's decision to hold its largest weekly gatherings on Sundays that has invited so much attention from non-members. As I noted earlier, many Muslims in Nigeria question Yoruba Muslims' ways of being Muslim. In fact, some non-Yoruba Nigeria Muslims look down on NASFAT, and its members are aware of this. The following remarks from a northern Nigerian Muslim intellectual are fairly typical. He told me that NASFAT is 'not very orthodox'. He claimed that NASFAT is essentially a Muslim Yoruba 'response to Christianity', whose members dress all in white, meet on Sundays and behave like Christians. In his view, NASFAT was too anchored in the Yoruba context and too mimetic of Christianity to be able to create and sustain universal appeal. In his view, NASFAT was destined to remain an exclusively Yoruba Muslim movement. Indeed, I have heard many Nigerians readily state that NASFAT is largely a Yoruba Muslim phenomenon and possibly even an atavistic form of 'Islamic Pentecostalism'.

\section{Conclusion}

NASFAT cannot be reduced to a 'response' to Christianity among the Yoruba or to trends in Pentecostalism. Its rise and rapid spread can only be understood within the recent social, political and economic context of Nigeria and the history of Yorubaland in particular. As I have shown, there is a very long tradition of Muslim youth founding new modern Islamic organizations in which they seek to distance themselves from their elders and partake in modernity and the opportunities it affords. Founded at a particular historical moment, NASFAT brought together Yoruba Muslims who sought to distinguish themselves from various others. These include fellow Yoruba who are Christians in all their denominational diversity but especially Pentecostals, other Muslims, Yoruba and non-Yoruba, including those who have called loudly for the implementation of sharia, and, last but not least, the ostentatious, that is, those social actors who are ubiquitous in contemporary Nigeria. Cognizant of the challenging circumstances most Nigerians face, NASFAT's leadership has devoted considerable attention to promoting ideas of unity, tolerance of one's fellow Muslims and 
non-Muslims, the provision of services the state has been unable or unwilling to provide, and an active engagement in business ventures with a view to facing the difficult economic conditions in the country, especially the chronic un- and underemployment of Nigeria's thwarted middle classes. NASFAT has been able to mobilize many people, combining individual attempts to reform the self ethically and advance economically. This particular case study illustrates how a new Islamic movement has been able to successfully organize and mobilize many Nigerian Muslims and seems to be helping them manage some of the serious social and economic challenges they face without necessarily leading to the kind of headline-grabbing social action that we have come to expect as evidence of a social movement and effective collective action. Given the paucity of interest on the part of social movement theorists in Islam, Muslim youth and Africa for that matter, such a case study of a new Islamic organization in Nigeria has much to teach these theorists about social movements in which religion is a key factor in social mobilization and action. At the same time, scholars of Islam and contemporary Muslim societies should accept the challenge to more actively engage with social movement theory from which they also stand to benefit, not least in the important endeavour of comparative reflection and theorizing. 


\title{
The United Democratic Front's legacy in South Africa: Mission accomplished or vision betrayed?
}

\author{
Ineke van Kessel
}

The United Democratic Front, formed in South Africa in 1983 to coordinate protest against a new constitution that co-opted Coloureds and Indians but excluded Africans from political representation, has been lauded as a model of a successful social movement. The UDF served as an umbrella forum for hundreds of organisations, including student movements, youth, women, churches, trade unions as well as community based organisations. While the affiliates pursued their own agenda, the UDF infused these struggles with a broader meaning. The UDF's vision of a new society was not limited to 'one man, one vote' and legal equality: it aspired to an egalitarian, non-racial society in which participation would be more important than the political pluralism of liberal democracy.

South Africa's post-apartheid constitution has been praised worldwide as a state-of-the-art model of liberal democracy, but it is quite remote from the grassroots democracy envisaged in the 1980s. Inequality has increased post-1994, in spite of considerable accomplishments in sectors such as infrastructure, housing, water and electricity and social welfare. Did the leaders of the UDF and the ANC betray the goals of the liberation struggle when they joined the comfortable life of the middle class and the business elite? Or did South Africa realistically have no other options available amidst the triumphant neo-liberalism of a rapidly globalizing world? This chapter explores the legacy of the UDF: how do former activists make sense of present-day South African society? 


\section{Introduction}

The United Democratic Front, formed in South Africa in 1983 to coordinate protest against a new constitution that co-opted Coloureds and Indians but excluded Africans from political representation, was the most inclusive social movement in South African history. The UDF served as an umbrella forum for hundreds of organizations involving youth, women, churches and trade unions, community-based organizations and student movements. These organizations each pursued their own agenda, ranging from free text books in schools to liberation theology and campaigns for lower rents and safer streets, but affiliation with the UDF infused these issues with a broader meaning. While tackling bread-and-butter matters, millions of South Africans felt themselves part of the liberation movement against apartheid. The UDF's vision of a just society was not limited to 'one man, one vote' and legal equality but aspired to a non-racial, egalitarian society in which participation and communalism would be the key values rather than the political pluralism and free-market principles of liberal democracy.

The UDF leadership emphasized that the Front was not a substitute for the banned liberation movements but it would hold the fort until the African National Congress could resume its rightful position. The ANC leadership in exile had given its blessing to the formation of the UDF as a broad front to coordinate the anti-apartheid struggle inside South Africa, while the ANC continued its underground activities as well as the armed struggle. However during the 1980s, the UDF developed its own distinct political culture. Its major goals were shared by all affiliates but modes of expression and political action varied considerably between affiliates as well as between the different geographical regions.

The ban on the African National Congress was lifted in 1990 and the UDF was disbanded in the following year. Its activists joined the scramble for positions within the ANC and subsequently in the government of the post-apartheid South Africa, at national, provincial and local level. While their primary goal the abolition of apartheid - has been accomplished, post-apartheid South Africa is a far cry from the erstwhile ideal of an egalitarian non-racial society. The 1996 constitution has been praised worldwide as a state-of-the-art model of liberal democracy, but it is quite remote from the egalitarian grassroots democracy envisaged in the 1980s. Inequality has increased since 1994 in spite of considerable accomplishments in areas such as infrastructure, housing, water, electricity and social welfare.

Did the leaders of the UDF and the ANC betray the goals of the liberation struggle when they joined the comfortable life of the middle classes and the business elite? Or did South Africa realistically have no other options available 
amid the triumphant neo-liberalism of a rapidly globalizing world? This chapter explores the UDF's legacy and considers how former activists are making sense of present-day South African society. There is a burgeoning academic and popular literature on the subject ranging from political economy perspectives to cultural studies. The case for 'betrayal' is argued by Patrick Bond, John Saul and many others, ${ }^{1}$ while authors like John and Jean Comaroff and Steven Robins take a different perspective and focus on the upsurge of identity politics in post-apartheid South Africa. ${ }^{2}$

I have opted here to focus on the perspectives and interpretations formulated by former UDF activists. The chapter is based on a research project in which I am revisiting the people and places that feature in my book on the United Democratic Front. ${ }^{3}$ Interviews for the book were conducted in 1990-1991 with the national leadership of the UDF in Johannesburg and with local activists in three case studies in the Western Cape, Sekhukhuneland (then part of the Lebowa Bantustan and now a rural area in Limpopo Province) and Kagiso and Munsieville, twin African townships to the west of Johannesburg. The interviews in the follow-up project were conducted in the same locations between 2006 and 2008.

\section{Mission accomplished or vision betrayed?}

The $25^{\text {th }}$ anniversary of the founding of the UDF on 20 August 2008 provided an excellent opportunity to gauge a range of opinions on the Front's legacy. Founding members profoundly disagreed on the crucial question about whether the UDF's mission had been accomplished or whether the ANC-in-government has betrayed their vision of a just society. Significantly, the commemorations were not only used to express nostalgia but also to voice a widely felt need for a new type of social movement, in the tradition of the UDF, to tackle current

1 John S. Saul, The Next Liberation struggle: Capitalism, Socialism and Democracy in: Southern Africa (University of KwaZulu-Natal Press, Scotsville, 2005); John S. Saul, 'The Strange Death of Liberated Southern Africa', paper presented at a seminar at the University of KwaZulu/Natal, 3 April 2007; Patrick Bond, Elite Transition: From apartheid to neoliberalism in South Africa (Pluto, London, 2000).

2 Steven L. Robins (ed.), Limits to Liberation after Apartheid: Citizenship, Governance and Culture (James Currey, Oxford, 2005); John Comaroff \& Jean Comaroff, 'Reflections on liberalism, policulturalism \& ID-ology: Citizenship \& difference in South Africa', in Robins (ed.), pp. 33-56; Jean \& John Comaroff, 'The struggle between the constitution and "things African"”, in The Wiser Review, July 2004.

3 Ineke van Kessel, 'Beyond our Wildest Dreams': The United Democratic Front and the Transformation of South Africa (University Press of Virginia, Charlottesville/ London, 2000). 
concerns such as HIV/AIDS, xenophobia, poverty, housing, public safety, health care and the crisis in education.

On the day of the anniversary, the Rocklands Civic Centre in Mitchells Plain, a largely Coloured working-class town near Cape Town, filled with a nostalgic crowd that came to pay tribute to the ideals and values of the UDF. It was at exactly this place that some 12,000 people had gathered 25 years earlier for the UDF's launch under the slogan 'Apartheid divides, UDF unites'. The launch of the UDF was the largest political gathering since the 1950s. In the course of the 1980s the UDF would develop into a very inclusive movement accommodating a wide range of activists and activities from prayer services, militant marches, strikes and boycotts to attempts at an insurrectionary takeover of power.

Those who gathered at Rocklands in 1983 saw themselves as part of the liberation movement that would free South Africa from apartheid. By contrast, the 2008 gathering was organized by the provincial government of the Western Cape, which invited eminent speakers such as the Minister of Finance Trevor Manuel who had been prominent in the UDF leadership in the 1980s. Among the notable absentees was Dr Allan Boesak, a patron of the UDF, and in the 1980s one of its most eloquent spokesmen. In newspaper interviews, Boesak explained why he boycotted the anniversary celebrations:

The celebrations (...) are not so much about the achievements of the UDF, since those achievements have all but disappeared from our political life, but more about campaigning for the next elections. I am uncomfortable with the thought that the same political party which moved with such unseemly haste to disband the UDF soon after the return of the exiles now celebrates the UDF as if it still existed. ${ }^{4}$

However another UDF founding member Minister of Defence Mosiuoa 'Terror' Lekota retorted that the UDF had achieved all of its goals. The UDF was launched to oppose the 1983 constitution and 'to appeal for the release of the prisoners, the return of the exiles and to start negotiations. There was nothing else that the UDF was supposed to achieve. ${ }^{5}$

Allan Boesak chose his own platform to lambaste the ANC for its betrayal of the UDF's legacy. In his keynote address at the annual Ashley Kriel Memorial Youth Lecture at the University of the Western Cape, Boesak received rousing applause when he described South Africa's political situation as a 'real and ticking time bomb' fuelled by the anger and frustration of those who had become disillusioned by unfulfilled promises and the greed of 'drunk with power' politicians. He accused leading members of South Africa's new elite of aban-

Cape Argus, 21 August 2008.

Die Burger, 22 August 2008. 
doning non-racialism 'for selfish politics and lust for power'. ${ }^{6}$ A crowd of over 2,000 largely middle-aged former activists chanted the familiar 'Boesak, Boesak' when the cleric entered the hall. Allan Boesak has a longstanding lovehate relationship with the ANC that dates from his conviction on charges of fraud and theft. He served one year of his six-year sentence and was released on parole in May 2001. Boesak then returned to a career in the church. Questions and comments after his speech made it clear that there was considerable pressure on Boesak to take up a leadership position once again. ${ }^{7}$ In a series of recent speeches and interviews, he spoke of a sense of alienation among Coloured people. While the UDF accommodated cultural diversity, thus providing a political home for African, Coloured, Indian and White South Africans, the ANC today is widely perceived as being a bastion of a more exclusive brand of African nationalism.

In his keynote speech at the official anniversary celebrations in Mitchells' Plain, Trevor Manuel also struck a critical note while painting a rather romantic picture of comradely solidarity and unity of purpose during the days of struggle in the 1980s. Manuel referred to the commitment, sacrifice and comradeship of the 1980s and regretted the demobilization of popular organizations in the 1990s. By relying excessively on the institutions of the state to deliver development, community organizations had 'sat back and allowed ourselves to be paralysed'. He criticized the lack of commitment in crucial sectors of the public service, notably education and health, and noted that 'the bulk of what we started remains incomplete'. Reminding his audience that revolutions are an ongoing process, he warned that 'revolutionary flames are extinguished by selfserving individuals and greed. We must know this and stop the hatred, bullying and personal enrichment.'

Manuel's speech was delivered during an episode of unprecedented factional quarrelling and backstabbing within the ANC, which in the following month (September 2008) would result in the ousting of President Thabo Mbeki and the ascent to power of Jacob Zuma's faction. It is perhaps against this background that his overly romantic notions of comradeship in the UDF can be explained:

We were armed with an unbreakable trust in each other - the trust had a name 'comradeship'. It allowed us to believe in each other and know that our backs would always be covered by those whom we called 'comrade'. Beyond that fundamental trust in each other, we were armed with self-belief - the path we were pursuing had never been walked.

6 Ibid.

7 Ryland Fisher, 'The rehabilitation of Allan Boesak'

(http://www.thoughtleader.co.za/rylandfisher, July 7, 2008). 
The phrase lauding the 'unbreakable trust' had other former UDF Western Cape activists sniggering. Although there is considerable nostalgia for the UDF days, activists acutely remember the factionalism and rivalry. Unlike Boesak, Manuel did not blame the ANC for disbanding the UDF but noted that UDF organizations had 'erred in giving up real power' after the exhilarating times of South Africa's first democratic elections in 1994.

Organizations began to whither away. Our means, the street committees and the civics were replaced with a false belief that elected councils were sufficient, and that the legislation calling for participatory democracy would be adequate. (...) We must now realise that the dream of a developmental state cannot ever be attained merely by parliament - we need public servants as the agents for transformation. (...) Laws alone are insufficient. We must get the institutions of the people to work. We must change the relationship between the state and public servants from one shaped by industrial relations to one where the measure is transformation for development.

In conclusion, Manuel stressed that the power won through the ballot box 'needs to be supplemented by the means of organized communities acting with government. Our power will mean nothing if we fail to reignite the self-belief in our people. ${ }^{, 8}$

Trevor Manuel and Johnny Issel were the two delegates from the Western Cape who travelled to Johannesburg in July 1983 to discuss the launch of the UDF with activists from Johannesburg and Durban. The factionalism in the UDF Western Cape is sometimes linked with their names: Isselites versus Trevorites. Tensions focused on the display of ANC symbols at public gatherings and later on recruitment in the armed struggle. ${ }^{9}$ Issel insisted on the public display of ANC symbols, while Manuel wanted to proceed more cautiously. Similar disagreements occurred elsewhere about whether priority should be given to building strong grassroots organizations or flag waving and popularizing the ANC. If the UDF openly identified with the ANC, it ran the risk of being banned before it properly took off. Issel is clear about his priorities: 'I was building the ANC: nothing would stand in my way. I used whatever was available. (...) I was a commander.' ${ }^{10}$

While Trevor Manuel embarked on a highly successful career, serving in every cabinet after 1994, Johnny Issel could not find a place for himself in postapartheid society. Issel, who describes himself as a professional activist, had expected the anti-apartheid struggle to culminate in an insurrection and not in

8 Trevor Manuel, 'Address to the $25^{\text {th }}$ anniversary of the UDF', Rocklands Civic Centre, Mitchells Plain, 20 August 2008; Cape Times, 21 August 2008; Cape Argus, 21 August 2008.

9 Interview with Johnny Issel, 2003 (http://www.sahistory.org.za/pages/libraryresources/interviews/2003 interview_jonny_issel.htm)

10 Interview with Johnny Issel, 10 September 2008, Cape Town. 
liberal democracy. He served for a while in the provincial legislature of the Western Cape but could not cope with party discipline. Subsequently he went into business but left South Africa in 2004 to spend a few years in Europe. 'I did not succeed in politics and neither in business. That challenged me to take stock of myself.' After suffering a couple of strokes and other health problems in London in 2006, he embarked on a 'spiritual journey that has given me calmness'.

At the time of my interview in Cape Town (September 2008), Johnny Issel, once a fiery activist steeped in Marx and Lenin, was into Buddhism. He had recovered sufficiently to be able to walk and suggested that I take him to Kirstenbosch Botanical Garden for the interview. Walking in these spectacularly beautiful gardens, we stopped to look at a framed photograph of Nelson Mandela. Stooping over the picture, Issel murmured: 'Is that not a pity that a man like Mandela is associated with the ANC?' I could not help laughing, and remarked that Mandela's entire life had been devoted to the ANC. He replied that he was not joking: 'It is a pity, what would Mandela think about the ANC today?' Johnny Issel, a lifelong professional activist, is no longer a member of the ANC and did not attend the UDF's $25^{\text {th }}$ anniversary celebrations in Mitchells Plain: 'I was not invited, while I single-handedly organized the launch of the UDF'. He now believes that the UDF should have continued after 1990 as it was a 'wonderfully broad movement' and that the ANC forced the UDF to disband because the ANC leadership, on their return from exile, saw the internal mass movement as a threat. ${ }^{11}$

For a cabinet minister, Trevor Manuel was, and still is, unusually frank in acknowledging the shortcomings of the ANC-in-government and in criticizing the complacency, self-interest, corruption, greed and self-enrichment that have characterized much of the public sector and significant sections of the ANC leadership since 1994. A common element in Manuel and Boesak's speeches is the need for a reinvigoration of civil society. While some dream of a renewed United Democratic Front, many more former activists are discussing the need for new social movements that are not adversarial to the ANC government but generate sufficient popular pressure to keep the government on track while encouraging more initiatives from below.

The need for a new UDF type of social movement was discussed in more detail at yet another commemorative event. Speaking at Belgravia High School in Athlone, another largely Coloured suburb of Cape Town, Andrew Boraine, treasurer of the UDF Western Cape from 1983 to 1985, member of the UDF National Executive and underground ANC activist in the late 1980s, stressed the need for a new United Front. The UDF stood for inclusive politics, non-

11 Ibid. 
racialism and alliances with all kinds of different partners who could further the anti-apartheid cause.

Today, the situation is different. We have a more narrow, exclusive, racially-based politics. There is extreme intolerance for dissenting views. There is an acute hostility in the ANC towards civil society. The government is not focused on building nonracialism. There is a widespread sense of alienation, of exclusion from the political process. We are now living through the disaster of factional politics. People are chosen because they belong to the right camp, not on the basis of any merit. Nothing can be more dangerous for South Africa's future. The sense of accountability that characterized the UDF gave way to an attitude of arrogance towards communities. Honest criticism is deflected.

Summing up the conclusion of his speech, Boraine recalled how he stressed the need for a new United Front to unite forces against poverty, and for jobs and skills. He believed that the disbanding of the UDF in 1991 had been inevitable. In other parts of South Africa, the UDF had dissolved spontaneously as activists flocked to the ANC. It was only in the Western Cape that its disbanding had been contentious but maintaining the UDF Western Cape would have meant in practice that it would have become a Coloured wing of the ANC, which would have been irreconcilable with its principle of non-racialism.

The problem was that civil society was disbanded. The ANC saw no need for an autonomous civil society, because it assumed that 'the ANC was the people', but that was true for only a short while.

In retrospect, Andrew Boraine believes that UDF activists made a fundamental mistake when they allowed the ANC to impose its hegemonic project and bring all organizations into line with the ANC.

The internal movement gave in too easily to the exiles returning. And who were these people? Essop Pahad was for ten years the editor of the Marxist Review in Prague. We used to read it religiously, but it was rubbish of course. (...) But we were so much in awe of the ANC leadership that we did not question any of it. ${ }^{12}$

Boraine was not calling for a resurrection of the UDF but for new networks and a more inclusive and cooperative mentality. However, calls for a new type of United Front reverberated even after the commemorations were over. After the dramatic ousting of Thabo Mbeki from the presidency, rumours about initiatives to launch a new party or movement in the tradition of the UDF kept appearing in the media. ${ }^{13}$ In October, a new party was indeed formed under the name Congress of the People (COPE), after the historic meeting in Kliptown where the Freedom Charter was adopted in 1955. Terror Lekota, UDF publicity secretary in the 1980s and Minister of Defence in Mbeki's cabinet, became the

12 Interview with Andrew Boraine, 15 September 2008, Cape Town.

13 Mail \& Guardian, 26 Sept-2 Oct. 2008, p. 2. 
chairman, while Allen Boesak agreed to campaign for COPE in the Western Cape. However, COPE does not seem to want to cast itself as the UDF's successor.

As is evident from the above, core UDF activists hold different perspectives about what constitutes the legacy of the UDF. While Johnny Issel was aiming for insurrection and a socialist revolution, Trevor Manuel and Andrew Boraine speak of the need to safeguard liberal democracy. Moreover, former UDF activists in the Western Cape are fairly unique in their nostalgia for the 1980s. The UDF Western Cape was dominated by Coloured and White activists, while Africans were not very prominent. In most other regions, the African activists in the UDF saw little or no distinction between the UDF and the ANC. For them, the UDF was founded as a temporary front for the banned ANC. Although I found widespread discontent about unfulfilled promises, there was little disagreement about the ANC's hegemonic project.

The different perspectives on the nature of the UDF can, in part, be explained by the demographics of the Western Cape. As a consequence of the Coloured Labour Preference policies, Africans formed a small minority in the Western Cape. In terms of apartheid policies, the Western Cape was to become an unofficial homeland for Coloured people: in 1980, Coloureds made up 54\% of the population of the Western Cape, while Whites constituted 32\%. The Coloured working class remained politically aloof, while Coloured intellectuals were more inclined towards Trotskyite organizations such as the Unity Movement. The ANC did have a presence in the African townships but the African population of the Western Cape formed a small minority of largely unskilled labour for a long time.

With the massive influx of Africans from the impoverished Eastern Cape, the Western Cape experienced a rapid Africanization, a process that continued at an accelerated pace in the 1990s and beyond. Stark changes in the demographic balance have no doubt contributed to a sense of alienation among Coloured people. This has been exacerbated by the ANC's affirmative action policies, which demand that the demographic profile be reflected in the employment profile in both the public and the private sector. In practice, this means that Coloured jobseekers in the Western Cape are now often bypassed in favour of African applicants.

The sense of frustration and alienation expressed by former UDF activists in the Western Cape has to be put into a wider perspective. The Western Cape is not representative of South Africa as a whole. Trevor Manuel, Allan Boesak and Johnny Issel were all classified as 'Coloureds' in apartheid terminology, while Andrew Boraine was a white student leader. My interviews with former UDF activists from Cape Town's African townships did not reveal similar levels of dissatisfaction. Although discontent is rife in other parts of South 
Africa too, this is expressed in different ways. Before analyzing the different perspectives of the UDF's legacy in more detail, I will briefly sketch its history and adhere to a somewhat chronological order while specifically addressing the themes outlined in the introduction: (i) the UDF's historical origins; (ii) the way it mobilized support and its support base; (iii) how the Front framed its message; (iv) the way the UDF related to other social movements; and finally (v) why it ceased to exist.

\section{What was the UDF?}

Origins

After the banning of the African National Congress and the Pan Africanist Congress in 1960, the ANC leadership regrouped in exile. The armed struggle and campaigns to isolate apartheid South Africa through boycotts and sanctions dominated its strategy for the first two decades of its existence. In the 1980s however, the leadership in exile took the strategic decision to rebuild massbased organizations inside the country. The UDF grew out of locally based initiatives but consultations were held with the leadership in exile as well as with the ANC underground.

During the 1970s, collective protest in South Africa was undertaken by two distinct social categories: black workers and black students. Their protest actions remained isolated phenomena rather than part of a coordinated rebellion. The 1980s however witnessed the growth of a broad-based social movement that mounted a sustained challenge to the apartheid state. From 1979 onwards, student activists actively sought to link up with community and workers' protests. School boycotts, rent and bus boycotts and the campaign against the imposed 'independence' of the Ciskei Bantustan all contributed to a new sense of optimism about the potential for mass mobilization and organization. Protest politics was shifting from uncompromising non-collaborationism to a more pragmatic result-oriented approach. By taking up the bread-and-butter issues that occupied people's minds at the local community level, activists succeeded in broadening popular organizations and involving a wide range of residents who would otherwise have been reluctant to become involved in overtly confrontational politics.

In the Western Cape, 1979 was a legendary turning point in popular politics. During a strike at a pasta factory, African and Coloured workers joined forces and linked up with community activists to organize a seven-month nationwide consumer boycott of the company's products. Students were drawn into the workers' struggle and workers became more politicized. This pattern of action, which brought victory for the unions, became a model for subsequent action, although another strike in 1980 in the meat industry ended in defeat for the 
unions. Elsewhere in South Africa, civic organizations began to emerge around 1980. 'Civics', as they came to be known, were local neighbourhood associations that took up residents' concerns about rents, electricity, transport, safety on the streets and education.

Around 1980 only the churches, the emerging independent trade unions and the (racially segregated) student organizations had a nationwide following. Student organizations proved important as recruiting and training grounds for activists. The Congress of South African Students (COSAS), formed in 1979, initially aimed to draw high-school students into community issues but after 1983 focused solely on school and student matters and limited its membership to high-school students. The now-excluded older and more experienced former students were instrumental in forming youth congresses, which took off in mid1983 with the youth playing a crucial role in the rebellion of the 1980s.

From 1981-1982, many of these organizations became involved in discussions on the formation of a United Front to counter government plans for limited constitutional reforms. However, problems arose during these discussions regarding non-racial organizations that included white members, such as the South African Council of Churches (SACC) and the recently formed Federation of South African Trade Unions (FOSATU). The role of the white student organization NUSAS, a UDF affiliate, was also contentious.

Ultimately, it was a call by Allan Boesak in early 1983 that would be remembered as the impetus to form the United Democratic Front. The UDF was set up as an $a d$ hoc alliance with the limited goal of countering the constitutional proposals of the governing National Party. The new constitution envisaged a tricameral parliament that would incorporate Indians and Coloureds in separate chambers, while whites would retain ultimate control. Africans would remain excluded from national politics: their separate ethnic 'national destinies' were to be pursued in the context of the Bantustans. As the government had come to accept the presence of Africans in urban areas as a permanent feature of a modern, industrialized state, urban Africans were to be given a very limited form of self-rule by elected town councils. These Black Local Authorities were responsible for raising their own revenue and the resulting rises in rents and service charges proved instrumental in igniting the township revolts of the mid 1980s.

FOSATU decided against affiliation with the UDF, wanting to maintain the autonomy of workers' organizations and to be able to take part in wider popular struggles on its own terms. The United Front formula posed the risk of workers being swamped by populist politics, as had happened to ANC-aligned unions in the 1950s. The smaller Council of Unions of South Africa (CUSA) affiliated to both the UDF and the Black Consciousness-oriented National Forum but ceased active participation in 1985, giving priority to merger negotiations with 
FOSATU. Most community unions, which were organized along community rather than industry-sector lines, did however join the UDF.

The national launch of the UDF on 20 August 1983 in Mitchells Plain was attended by about a thousand delegates, representing some 575 community organizations, trade unions, sporting bodies and women's and youth organizations. As more organizations joined, UDF spokespersons measured the strength of the Front in a convenient shorthand: 600 organizations representing 2 million people. However, of the 575 organizations represented at the launch, 235 were branches of the Western Cape Inter Church Youth, a recently founded body of which not much was heard in subsequent years. The formula was eminently suitable for public-relations purposes and the UDF would stick in popular memory as a front representing some 600 organizations and 2 million people.

The UDF's first test of strength was the campaign for a boycott of the tricameral elections and the municipal elections for the Black Local Authorities. The boycotts were a resounding success. The state's efforts to co-opt Coloureds and Indians and a small elite of urban Africans had evidently failed. Widespread school boycotts accompanied the campaigns. Running parallel to the election boycotts and school protests, a third source of unrest was locally based community protest against increases in bus fares and rents. A series of township revolts began on 3 September 1984 with a two-day stay-away from work in the townships of the Vaal Triangle, a heavily industrialized region south of Johannesburg, in protest against rent increases. The Vaal uprising left 26 people dead and more than 300 injured. By the end of the 1980s the number of 'victims of the unrest' had exceeded 5,000.

These disparate strands of protest came together in a major stay-away from school and work in the Pretoria-Witwatersrand-Vereeniging area on 5 and 6 November 1984. Significantly, FOSATU and CUSA participated in an overtly political protest action for the first time. COSAS activists were instrumental in the preparations. This joint effort by students and workers provided the basis for optimistic strategizing about the emerging student-worker alliance. By the end of 1984 it was clear that South Africa had entered a phase of unrest that would be more serious than the Soweto Uprising of 1976.

After the successful boycott campaigns of the tricameral elections, the UDF transformed itself from being an ad hoc alliance into a more permanent movement that addressed a broad range of issues. It took the Front about six months to reorientate itself and develop a new agenda. Meanwhile, dozens of townships were the scene of escalating and sometimes violent protests against the Black Local Authorities and their attempts to raise revenue to cover their administrative costs. Local protest was mostly led by civic associations. Although most - but by no means all - civics were affiliated to the UDF, the Front had little control over local protest actions. From 1985 onwards however, the UDF leadership began to realize more clearly the mobilizing potential of bread-and-butter issues. Civics that dealt with everyday con- 
cerns could attract large numbers of not strongly politicized township residents. But political guidance was needed to infuse local struggles with a broader meaning. Through the UDF, disparate struggles regarding housing, transport, education and the cost of living could be seen as part of the fight against both apartheid and capitalism.

In July 1985, the funerals of three assassinated civic leaders from the small town of Cradock in the Eastern Cape drew a crowd of around 40,000 amid a massive display of ANC and SACP (South African Communist Party) flags. On 21 July 1985, the government declared a partial state of emergency and thousands of people were detained. In August, COSAS became the first UDF affiliate to be declared an unlawful organization. Two major treason trials ensured that a substantial part of the UDF leadership was taken out of circulation.

During the first two years, the Front was largely reactive but after 1985 the UDF no longer limited itself to reacting to and protesting against government policy. In numerous places, activists started undertaking a far more ambitious project: the construction of a new, egalitarian and morally just society. Civics were transformed into 'organs of people power'.

The first State of Emergency (July 1985 - March 1986) did not crush the rebellion but instead inspired new tactics. Consumer boycotts were introduced as a new political weapon, and with mass gatherings prohibited, street committees proliferated. Boycotts were hailed as an essentially peaceful Gandhian tactic of passive resistance but the enforcement of boycotts frequently entailed the use of physical force and harsh punishments. Successful boycott campaigns conducted by broad-based township organizations relying on participatory structures of decision-making served to reinforce the political and moral authority of the civics and other movements that stood for an alternative social order. Conversely, coercion, intimidation and abuse by undisciplined youth weakened support for boycotts. In several places, white-owned businesses proved ready to negotiate but local victories were necessarily limited without back-up from central or local government.

With school boycotts becoming a chronic rather than intermittent means of protest, the Soweto Parents' Crisis Committee was formed in September 1985 with the aim of encouraging high-school students back into school. Eventually, in December 1985, the ANC gave its blessing to the parents' initiative, which later widened into a nationwide campaign under the banner of the National Education Crisis Committee (NECC). The NECC supported the students' demands but transformed the slogan 'No Education before Liberation' into 'People's Education for People's Power'. Its efforts met with only partial success.

Boycotts gave ordinary people a sense of power. Many activists believed that a phase of 'dual power' had arrived and that a revolutionary takeover was imminent. But the pattern of resistance was uneven and coordination was lack- 
ing. It was not the UDF itself but local affiliates and people loosely associated with the UDF that wielded power in the townships. Officially, the UDF stuck to non-violent methods but the leadership was reluctant to condemn excesses such as the 'necklacing' (a car tyre doused with petrol) of suspected informers. On the one hand it feared alienating militant youth but on the other the leadership doubted its own capacity to exercise control over its unruly followers. When ANC President Oliver Tambo finally condemned necklace executions in 1986, his pronouncement had no visible impact inside South Africa.

More durable than the fledgling structures of people's power was the workers' power that manifested itself in a new giant federation of trade unions, the Congress of South African Trade Unions (COSATU). On 1 December 1985, over 10,000 people attended the launch of COSATU in Durban. In contrast to its predecessor FOSATU, the leadership of the 33 COSATU unions held that unions ought to be involved in community struggles and the wider political arena.

People's Power

The State of Emergency was lifted in March 1986. With rebellion spreading to remote corners of South Africa, boycotts flaring up intermittently, mounting international solidarity campaigns and increasing signs of nervousness among white businesses, the UDF felt confident that 'the people' would soon be empowered to shape their own destiny. 1986 marks the height of 'People's Power', of the belief that representatives of the people, even 'the people themselves', were marching to take control of 'liberated areas'. Liberated areas were defined in geographical terms and, as with townships, became no-go areas for the police. But the term could equally apply to spheres of life where 'the people' were taking over, such as schools, the community media or organs of popular justice. People's courts signified perhaps the most fundamental challenge to state authority as they exposed the lack of legitimacy of the apartheid state's criminal justice system. In some townships, people's courts were widely appreciated for their role in curbing crime, disciplining unruly youth and solving domestic conflicts. But elsewhere, these courts were resented for their harsh and arbitrary punishments and, if they were run by youth, they lacked legitimacy in the eyes of older residents.

The second State of Emergency, imposed nationwide on 12 June 1986 and lifted only in 1990, virtually amounted to military rule. Dozens of national and regional UDF leaders were detained, along with some 25,000 other South Africans, many under the age of 18 . State repression was combined with a shady system of unofficial repression and activists became targets of faceless death squads and vigilantes. In October 1986, the UDF was declared an 'affected organization' and was thus prohibited from receiving overseas funds. Many 
affiliates and sympathetic organizations (churches, human-rights organizations, etc.) were, however, able to maintain access to foreign funding.

Although the UDF was badly hit, the State of Emergency did not bring township life back to 'normal'. Rent boycotts continued and provided a key rallying point for township activists. Street committees organized youth brigades to prevent the eviction of rent defaulters and where electricity had been cut off, volunteers moved in to reconnect township houses. Rent boycotts acquired their own momentum. Even without its political content, this tactic had obvious advantages as it augmented family income. Consumer and bus boycotts flared up intermittently but township residents began to show signs of exhaustion and a loss of patience with the 'rule of the comrades', young militants who often used heavy-handed and coercive methods. The fate of the UDF seemed sealed when it was effectively banned in February 1988. UDF leaders not in detention went into hiding. Youth organizations adapted to a semi-underground existence, but most civics ceased to function.

This period of despair and forced inactivity had a sobering effect on leading activists. When new political space opened up in 1989, they emerged from detention and hiding with a new realism. No longer intoxicated by views of imminent liberation and insurrectionary bids for power, they set out to rebuild organizations.

In the early months of 1989, the Mass Democratic Movement (MDM) asserted itself on the streets of the big cities. The main components of this flexible alliance were the UDF, COSATU and church leaders. The MDM and the remnants of the Black Consciousness Movement organized the Conference for a Democratic Future in December 1989, which called for a non-racial constituent assembly to draw up a new constitution. This year of transition from semi-legality to a fully legalized status for the ANC, SACP and the PAC was characterized by a new mood of pragmatism and a series of local negotiations prepared the way for talks on the central issue of state power.

\section{Disbanding the UDF}

After the lifting of the ban on the ANC in January 1990, the release of Nelson Mandela and his co-accused from prison and the return of the ANC leaders from exile, UDF activists deferred to the leadership of the historic liberation movement. In popular imagination, the ANC leaders in exile and those on Robben Island had acquired the status of larger-than-life heroes. Two sections of the UDF - youth congresses and women's' organizations - merged almost immediately with the ANC Women's League and the ANC Youth League. Within the UDF, three options were discussed: (i) disbanding; (ii) transforming itself into a coordinating structure for civil-society organizations; or (iii) waiting and making a decision later. 
The argument for disbanding the UDF was that the Front had served its purpose and the ANC could now resume its rightful place. The UDF's continued existence would only cause duplication and confusion. The second option was to transform the UDF into a coordinating structure for civics, student organizations, religious bodies and those youth and women's organizations that decided against merging with the Women's' League and the Youth League. This position was favoured both by activists, who argued that an umbrella structure was needed to exercise hegemonic control, and by the proponents of an autonomous civil society. The wait-and-see option prevailed in 1990 but in 1991 the UDF decided to disband. Dissolution had become a foregone conclusion, as the UDF's most capable activists had been absorbed into the ANC. Paradoxically, the lifting of the ban on the ANC had a demobilizing effect: many people believed that they could now rely on the ANC to solve their problems. The UDF officially disbanded on 20 August 1991, exactly eight years after it had been launched. A dissenting voice came from Allen Boesak who believed that Coloured people in the Western Cape would be left without a political home as they saw the ANC as an African-dominated movement. The exiles and former prisoners who dominated the ANC Western Cape showed little understanding of local dynamics. His position that the UDF should be dissolved gradually as the need for it disappeared was not shared by other UDF activists.

\section{Mobilizing a mass following: Methods and means}

One of the characteristics of the UDF was its adroit use of a broad variety of media. Links with student organizations on campus and different resource centres offered access to facilities for printing, photocopying, printing T-shirts etc. The UDF and its affiliates produced vast numbers of posters, newsletters, community newspapers, ideological treatises, banners and T-shirts, which resulted in a high level of visibility.

The UDF leadership displayed a keen awareness of the importance of public relations. It was able to count on sympathetic coverage in many domestic publiccations and in the international press. Where the ANC had a mixed reception due to its commitment to armed struggle, the UDF gained nearly universal popularity in the world's media.

The use of low-threshold campaigns that focused on people's immediate daily concerns rather than on high-brow politics proved appropriate when organizing large numbers of township residents. In the second half of the 1980s, violent repression by the security forces angered many ordinary people who until then had not been particularly politicized. Feeling under threat from a vindictive police and faceless death squads, township residents developed a strong sense of community. 
In the early years, the UDF was largely dependent on local donations but from 1985 foreign funding started flowing, transforming the UDF from a movement that relied on volunteers and spontaneity to a more bureaucratically run organization employing considerable numbers of organizers. Foreign funding paid for some of the members' transport and accommodation costs at national and regional conferences, and for telephone and fax bills. The availability of (overseas) funding was thus crucial to the project of building a nationwide political movement. According to Azhar Cachalia, the UDF's treasurer, 'a lot more than half' of the UDF's funding came from abroad. ${ }^{14}$

Inevitably, control over resources, notably funding, was a source of dispute between UDF regions and UDF Head Office, as well as between and within affiliates. Compared to trade unions or the ANC after the ban on it was lifted, the UDF was run on a very modest budget. In 1989-1990, the UDF had an income of about R.1.7 m, excluding grants for specific expenses such as the Conference for a Democratic Future. Numerous affiliates, like community newspapers, advisory offices and civic organizations, had their own sources of local and/or foreign funding, allowing them a considerable degree of autonomy.

\section{Making sense: Framing the message}

The UDF not only coordinated and directed internal resistance to apartheid but also provided a cultural framework that lent a wider meaning to a variety of local struggles. By participating in rent boycotts, stay-aways, boycotts of whiteowned businesses and school protests, people not only addressed their immediate concerns but played their own part in the struggle for a new social, political and economic order.

The UDF's vision was for an egalitarian, non-racial society with a strong emphasis on grassroots participation. Participation was more important than pluralism. This vision of a just society also had a strong moral component and religious inspiration and legitimation were characteristics of many activities. UDF followers were not only engaged in a struggle against apartheid and capitalism but also against the forces of evil.

Although its leadership clearly identified with the banned ANC, they initially decided against adopting the Freedom Charter. Advocating the Freedom Charter would probably have invited state repression and limited the Front's possibilities of expanding beyond the known Charterist organizations. Only in August 1987 after COSATU had adopted the Freedom Charter did the UDF follow suit. Oliver Tambo's message on 8 January, broadcast on the anniversary of the founding of the ANC, provided a sense of direction to UDF activists who religiously tuned in for the latest guidelines. Affiliates and regions maintained

14 Interview with Azhar Cachalia, 25 January 1992, Rotterdam. 
their own lines of communication with the ANC centres in exile. They all claimed to be toeing the line prescribed by the organization.

\section{Alliances: Inclusion and exclusion}

The UDF never had a constitution, only a set of Working Principles that stated that affiliates would retain their organizational autonomy. The UDF's umbrella formula proved eminently suitable for combining a broad range of organizations, from middle-class whites to rural African youth. The Front's formula enabled people to identify with the banned ANC but without exposing themselves to state repression. It allowed for organizational flexibility and accommodated a range of manifestations of protest and rebellion, from prayer services to militant youth actions. The UDF configured visions of an alternative social, political and economic order without imposing a political orthodoxy on its heterodox following.

Although the UDF as a multi-racial, multi-class alliance was undoubtedly the most inclusive movement in South African history, it could not claim to represent all the peoples of South Africa. In terms of race and ethnicity, it was truly inclusive. The main trade unions however opted to remain outside the UDF ambit, even though a fairly good working relationship developed in the second half of the 1980s. Liberal whites were reluctant to fully associate with this increasingly radical social movement but found a common platform on human-rights issues. Big business (which was, by definition, white business) could not be an ally in view of the UDF's anti-capitalist platform. However the Front did attempt, with some success, to lure business away from the apartheid government's disastrous policies.

Some sections of South African society were notably absent from both UDF structures and discussions on organizational strategy. The independent African churches, domestic workers, farm workers, migrant workers and squatters remained on the margins. The UDF's own principles excluded Bantustan-based structures, such as Inkatha. Some of the heirs of the Black Consciousness Movement, notably AZAPO (Azanian People's Organization) formed their own platform in the National Forum, but this never developed into a mass movement.

\section{UDF legacies}

From universalism to particularism: What happened to non-racialism?

The struggle against apartheid was framed in terms of universal values. The ANC-in-exile campaigned to have apartheid condemned as a crime against humanity. Nowadays ANC politicians make frequent recourse to the particularist values of Africanist ideologies, advocating 'African solutions for African 
problems' or invoking 'African traditions'. In the case of Zimbabwe, the call for 'African solutions' - meant to delegitimize policy interventions from the West often comes from the very same politicians who once campaigned for sanctions and boycotts of apartheid South Africa.

A recent example is a statement by Cassel Mathale, the ANC's candidate for the Limpopo premiership. As the Mail \& Guardian reported, Mathale is a director of at least ten companies in the mining, construction, farming and hospitality sectors, some of which have benefited from lucrative government contracts in Limpopo. 'This thing of conflict of interest is just a fabrication', Mathale said. 'As Africans we must not allow that. We should allow everyone to go into government. (...) The most important thing for us [as politicians] is to disclose our business interests to the public. ${ }^{15}$ In the 1980s, activists claimed their rights as South Africans and as fellow human beings. Now apparently, a prospective premier claims that 'as an African' he cannot be bothered with concerns about conflicts of interest.

African nationalism seems set to become the new hegemonic discourse. It may indeed provide the glue by securing the loyalty of the ANC's main constituency but in the process another cherished principle of the liberation struggle, non-racialism, is increasingly coming under pressure. Numerous Coloured, Indian and White UDF activists have become disillusioned with the exclusive brand of African nationalism that has succeeded Mandela's Rainbow Nation. Although they may be quite content with their careers and current status in society, they are no longer active members of the ANC. The UDF provided them with a political home but their initial enthusiasm for the ANC was dampened by a sense of non-belonging. In 2007, journalist Ryland Fisher, a former UDF activist in the Western Cape, published a book entitled Race. In the introduction, he argues that issues of race, racism and race-consciousness continue to pervade every corner of South African society. Like many Coloured students of his generation, Fisher adopted the identity of 'black', influenced by the writings of Steve Biko.

Recently, however, I have noticed that people who used to accept me as black now refer to me as coloured and, by that action, exclude me and others who may or may not look like me from the majority of South Africans once again. ${ }^{16}$

Have the erstwhile ideals of a participatory, egalitarian society been betrayed? Whatever happened to socialism?

The participatory ethos is no longer as central as it was in the 1980s, although there are numerous interesting initiatives ranging from ward committees to PPP

15 Mail \&Guardian, 29 July 2008.

16 Ryland Fisher, Race (Jacana Publishers, Johannesburg, 2007), p. 5. 
(Public Participation and Petitions) units at provincial government level to the recently introduced community development workers. In many cases, however, these lines of communication amount to a top-down exercise in the management of public opinion.

As in the 1980s, I encountered a profound distrust of pluralism in my recent interviews in 2006-2008. ANC politicians in Sekhukhuneland tend to view opposition as illegitimate. It is acceptable to have the Democratic Alliance in Cape Town as that is something for whites, anyway. However, in one's own district, municipality or constituency, rival political parties such as the PAC and AZAPO ought to be silenced, sidelined or even 'crushed'. The distinct historical traditions in different parts of South Africa have produced different understandings of the concept of 'democracy'. The ANC has been deeply rooted in Sekhukhuneland for at least half a century. When I conducted my research in 19901991 into UDF affiliates such as the Sekhukhune Youth Organization (SEYO), I found that many activists had never heard of the UDF. Through their activities in youth movements, they belonged to 'the organization', and 'the organization' was the ANC.

Activists in Kagiso in the 1980s were organized in a civic association called the Krugersdorp Residents' Organization (KRO) that was affiliated to the UDF. Most township activists saw themselves as KRO activists. The Africanist tendency in Kagiso organized a rival civic association. The Western Cape lacks a strong ANC tradition but has a long history of fragmented political opposition as well as religious diversity. In the 1980s, UDF activists in the Western Cape were not inclined to accommodate political rivals in the anti-apartheid struggle but nowadays most former activists here view political pluralism as an essential characteristic of constitutional democracy.

About 1990, activists framed their aspirations in Marxist terms. When asked about his vision for South Africa, Maurice Nchabeleng, a youth leader in Sekhukhuneland, stated: 'I want the dictatorship of the proletariat'. Looking back, he now reformulates his ambitions at the time as: 'We wanted to go to the place of the whites'. ${ }^{17}$

Activists wanted a better life modelled on the comfortable lifestyle of white South Africans. This aspiration was framed in the dominant discourse of the liberation struggle at that time, i.e. a mix of Marxism and African nationalism. Marxism seemed to make eminent sense as an analysis of South African society and it also assured, with scientific certainty, that the class struggle would lead the workers to victory. Being versed in Marxism added to one's prestige as an 'advanced cadre'.

17 Interview with Maurice Nchabeleng, 10 March 2007, Apel. 
Nowadays, becoming rich and focusing on individual advancement have become acceptable aspirations in ANC circles. Former activists frame their hopes in today's dominant terminology. But have the aspirations really changed? Or is it the mode of expression that has changed?

Egalitarian ideals are currently out of fashion. Among various former activists, Mrs Thatcher's TINA (There Is No Alternative - to the free market and liberal orthodoxy) has become received wisdom. Others do indeed speak of betrayal but more often than not they feel betrayed by former comrades rather than by more abstract ANC policies. Some critics of the neo-liberal order seem genuinely committed to their belief in a more just society but others just want a share of the riches. A former youth leader in Sekhukhuneland eloquently expressed his frustrations:

Self-proclaimed communists have become capitalists. The ANC has become a bourgeois national democratic movement. Only people with money own the ANC. The SACP has become a forum for people who missed out on opportunities and positions. Some of them know nothing about communism. ${ }^{18}$

Still versed in Marxism, Moss Mabotha had a ready explanation: 'one's world outlook is determined by one's class position'. But in spite of all the articulate criticism, the bottom line of his resentment is that he wanted to be part of the good life. He admitted to being jealous: 'I also want to be rich'.

Although many former activists expressed a sense of dissatisfaction, their discontent was more often than not focused on former comrades in the struggle rather than on ANC policies per se. Youth leader Silas Mabotha, now a highschool principal in Sekhukhune, remarked that relations of trust among former comrades have been undermined: 'We cannot even advise former comrades because they suffer from paranoia. They think you are after their job.' Silas Mabotha, a respected militant and articulate youth activist, is no longer active in the ANC, 'just like most of us'. The ANC government, he complains, follows a capitalist agenda:

The BEE (Black Economic Empowerment) is nothing else but building a black bourgeoisie. Unemployment is growing while some people become super rich. We see privatization, and casualization of labour. That is not what we fought for, privatization. They are trying to do away with government altogether.

However Silas Mabotha also wants to share in the fruits of liberation: 'We are worried that they will have run out of Mercedes before our turn has come'. ${ }^{19}$

Activists' networks in the 1980s were characterized by strong bonds of solidarity, and differences in socio-economic status between activists were generally quite modest. The stark increase in socio-economic differentiation since

18 Interview with Moss Mabotha, 15 March 2007, Polokwane.

19 Interview with Silas Mabotha, November 2006, Apel. 
1994 has put considerable strain on comrades' networks. Can solidarity networks survive when members find themselves in vastly different positions? Is jealousy perhaps a means of keeping members in check and reminding them of their obligations towards group members?

\section{Whatever happened to constitutionalism?}

Why would the ANC want to undermine the very constitution that it fought for? In the political crisis that unfolded in the wake of ANC President Jacob Zuma's corruption trial, attacks on the courts by leading ANC personalities were fairly common place. Newspaper editorials and political analysts warned that the independence of the judiciary was at stake and wondered why the ANC would want to undermine the very constitution that it had fought for. ${ }^{20}$ But this argument is based on incorrect assumptions.

The ANC accepted the constitution as part of the negotiated transfer of power but a liberal democratic constitution was not among the goals of the liberation struggle. Neither the ANC nor the UDF envisaged a system of liberal democracy. In the 1980s, 'liberal' was a term of abuse. The UDF's preferred mode of governance was popular democracy, modelled on that in Cuba, the German Democratic Republic or Frelimo's Mozambique.

The present South African constitution has been praised worldwide as a model of liberal democracy but liberal democracy was not what spurred on the masses who took to the streets in the 1980s. The clauses about gender equality, gay rights, the abolition of the death penalty and the legalization of abortion would in all likelihood not survive a referendum. However, the fundamental flaw in the view of many black South Africans is the property clause: a constitution that protects the ill-gotten gains of centuries of dispossession and apartheid lacks legitimacy. Did the Freedom Charter not promise that South Africa's national wealth, 'the heritage of all South Africans, shall be restored to the people'?

\section{New social movements}

While former activists met in late August 2008 to share nostalgic reminiscences of struggle solidarity, unity and clarity of purpose in UDF days, the ANC went through its worst crisis since 1994. In the aftermath of Thabo Mbeki's forced resignation as president on 20 September 2008, disgruntled ANC members discussed their options: to break away and found a new party or to attempt to recapture the ANC? Others spoke of the need for new social movements. One

20 For example in the Mail \& Guardian, 11 July 2008. 
such initiative, which aspires to operating in the tradition of the UDF, is the Coalition for Social Justice.

The Coalition for Social Justice was formally launched on 25 June 2008 in Saltriver, a suburb of Cape Town, in response to a series of xenophobic attacks on foreign nationals in the Western Cape. When the government's reaction to the refugee crisis was slow and haphazard, individuals and local organizations began providing humanitarian relief. As the announcement of the public launch of the Social Justice Coalition (SJC) stated:

Lack of faith in the government, city, big business and even civil society has led us to respond individually and voluntarily. The Social Justice Coalition is an independent group that believes in freedom, equality, non-violence and [a] human rights framework that respects among others, the right of every person to life, dignity and access to health care. We commit ourselves to build a Social Justice Coalition that promotes a 'Marshall Plan' for development in South and Southern Africa based on prioritizing and meeting the needs of the poor and steadily and visibly reducing social inequality.

The core organization in this new coalition is the Treatment Action Campaign (TAC), itself a coalition of individuals and organizations that have successfully campaigned for adequate health care and access to anti-retrovirals for those with HIV. The TAC's campaign strategies were modelled on the UDF model of social activism, employing a broad range of tactics including mass protests, petitions, recourse to the courts, expert lobbies and international pressure on the South African government.

SJC meetings have attracted sizable crowds of young people as well as a number of prominent South Africans with good track records in human rights and anti-apartheid activism. Apart from the refugee crisis, the SJC has also highlighted the perceived laxity of the Mbeki government in addressing the crisis in Zimbabwe and the attacks on the judicial system following Jacob Zuma's court case. $^{21}$

Media reports on the SJC often associate this new broad-based initiative with the legacy of the UDF. The SJC is of course not the only new social movement to spring up in post-apartheid South Africa. As described by Richard Ballard et al., three overlapping but distinct types of struggle emerged when the honeymoon period of Mandela's presidency was over: ${ }^{22}$

21 Public Launch of the Social Justice Coalition (http://www.tac.org.za/community/node/2356, June 20, 2008); Mail \&Guardian ,14 September 2008.

22 Richard Ballard, Adam Habib \& Imraan Valodia (eds), Voices of Protest: Social movements in post-apartheid South Africa (University of Kwazulu-Natal Press, Scotsville, 2006), p. 2. 
- Initiatives were directed against various government policies. The classic case here is the opposition by the Congress of South African Trade Unions (COSATU) to the Growth, Employment and Redistribution (GEAR) strategy that represented the post-apartheid government's decision to engage with trade liberalization and pursue economic growth as the mechanism for facilitating employment, and thereby promote redistribution.

- Other struggles focused on government failures to meet basic needs and address socio-economic rights. The most noted examples are the Landless People's Movement and the Treatment Action Campaign (TAC) that respectively address the slow pace of land redistribution and the government's failure to respond adequately to the HIV/AIDS crisis.

- Some struggles emerged to directly challenge the local enforcement of government policies and to resist government attempts at repression. The Soweto Electricity Crisis Committee, the Concerned Citizens Group and the Anti-Eviction Campaign are all attempts to organize poor and marginalized communities to resist local, provincial and national government attempts to cut off electricity and water, and evict residents.

In most cases however, these movements and organizations address a single issue. Attempts at building a broader platform that addresses a range of issues have been few and far between. Here the Social Justice Coalition may possibly provide an impetus towards a broader-based movement. 


\title{
'Campus Cults' in Nigeria: The development of an anti-social movement
}

\author{
Stephen Ellis
}

Nigerians have become concerned by the problem of 'campus cults' - initiation societies rooted in the country's university and college campuses that are part-student club and part criminal gang. Some religious authorities regard certain of the campus cults as 'satanic' by reason of their activities and rituals. The anti-social aspects of these organizations are largely attributable to their manipulation by military governments as a counter to conventional student organizations. The campus cults are quite literally an example of an anti-social movement.

For the last decade or so, Nigerians have been concerned with the problem of 'campus cults'. This is the name given by the press to certain student organizations that have proliferated on university campuses and that have become associated with a wide range of abuses and crimes, including murder. As time has gone by, people who joined such cults during their student years have graduated and advanced in their careers to the point that the existing campus groups are now connected to networks of cult members with senior positions in business or government. 'Campus cults', may, therefore, have their organizational centres in the nation's universities but their networks have spread through state and society.

Christian Pentecostal preachers in particular regard student cults, many of which bear ghoulish and gothic names, as manifestations of Satanism and call on cult members to break their links with them. Billboards on campuses warn about the dangers of such groups and urge students to shun them. Exactly how many distinct campus cults exist is impossible to say with precision but there would appear to be more than a hundred, with many thousands of members. 
Membership appears to be overwhelmingly male but there are also organizations that are exclusively for women.

Cults of this nature can hardly be called social movements since they are closed rather than open, and serve private interests rather than aspiring to work for the common good. By most accounts, however, things were not always this way. The organizations called 'campus cults' today represent a perverse and destructive aspect of a student movement that is otherwise social in its orientation. 'Campus cults' have developed at the heart of the wider student movement. The nature of this relationship is such that it raises questions concerning the character of social action in Nigeria generally.

Nigeria's first university was established in Ibadan in 1948 and was originally known as University College, only later being renamed the University of Ibadan. After independence in 1960, the number of universities mushroomed, especially during the oil boom of the 1970s when the government founded universities in every part of the country. More recently, various individuals, corporations and religious bodies have established private universities, to the extent that there are now almost 100 universities recognized by the Nigerian Universities Commission, as well as 100 polytechnics and 150 technical colleges. Despite this growth, demand for one of the estimated 148,000 annual university places remains fierce and the expansion in the number of universities has, in fact, damaged students' job prospects, with graduate unemployment now estimated at about $60 \%{ }^{1}$

\section{The Pyrates and its offspring}

Nigeria's first main nationalist party, the National Council of Nigeria and the Cameroons (NCNC), recruited heavily among students. ${ }^{2}$ It was in this context that in 1953 (or, in some accounts, 1952), University College Ibadan witnessed the foundation of a new type of student club conceived along the lines of an American student fraternity or a British university social club. Founded by seven undergraduates, it was known as the Pyrates Confraternity. According to a later analyst, who received an official appointment to investigate campus cults, the Pyrates originally aspired to 'a social liberating role', and represented 'an attempt to create a better society'. ${ }^{3}$ It aimed to galvanize the fusty, Oxbridge-style atmosphere of what had been Nigeria's only university for some twelve years and to lobby for a more radical university politics generally. The

1 John Gill, 'UK looks set to benefit from Nigerian student boom', Times Higher Education Supplement, 11 December 2008.

2 Daniel A. Offiong, Secret Cults in Nigerian Tertiary Institutions (Fourth Dimension, Enugu, 2003), p. 1.

3 Ibid., p. 3. 
leader of the group was the young Wole Soyinka, who would later become a Nobel laureate. Embarrassed by what some student confraternities were to become, Soyinka has written a defence of the Pyrates in which he emphasizes the organization's youthful innocence. ${ }^{4}$ As new universities were created, the Pyrates became popular on many of the new campuses, founding a branch, for example, at the University of Nigeria at Nsukka that was opened shortly after independence.

Nigerian student politics in the 1960s and 1970s, as in many other countries in Africa and indeed other parts of the world, were dominated by a rhetoric of radicalism. The most influential student leaders were stridently anti-colonialist. Marxism, pan-Africanism and opposition to apartheid in South Africa became favoured themes of student activists. The 1962 abrogation of the Anglo-Nigerian defence agreement, negotiated on the eve of independence, was attributed in part to pressure from student opinion. ${ }^{5}$ As the number of students increased with the opening of new universities, the National Union of Nigerian Students (NUNS) became directly involved in national politics, being invited to join the 1977 Constituent Assembly that was discussing a new constitution that would accompany a return to civilian rule, replacing the military administrations that had run Nigeria since the country's first coup in 1966 . However, the military government under General Olusegun Obasanjo, who led the country from 1977 to 1979 , became so annoyed by the students' radicalism that it proscribed the NUNS and detained its president, Segun Okeowo. Radical university lecturers in Ibadan, Lagos, Calabar and at Ahmadou Bello University in Zaria were detained or fired. ${ }^{6}$

The Pyrates was generally in sympathy with the radical turn taken by student politics and remained an influential force within the student movement. Ben Oguntuase, a Pyrate in the early 1970s, later recalled that the confraternity was at that time the driving force in student politics at the University of Ibadan. ${ }^{7}$ Another ex-member recalled the Pyrates in those days as offering 'an avenue to express strong feelings about the happenings in society', ${ }^{8}$ still assuming the role of social gadfly that the organization had had at its inception. According to Oguntuase, by the early 1970s, members of the Pyrates wore uniforms for for-

4 Wole Soyinka, Cults: A people in denial (Interventions III, Bookcraft, Ibadan, 2005), esp. pp. 58-74.

5 cf. Gordon J. Idang, 'The politics of Nigerian foreign policy: The ratification and renunciation of the Anglo-Nigerian defence agreement', African Studies Review, 13, 2 (1970), p. 229.

6 Reuben Abati, 'How Nigerian students murdered democracy', The Guardian, 11 December 2005.

7 Interview in Punch, 8 August 1999.

8 Femi Olugbile, 'Cult fever', Vanguard, 15 August 1999. 
mal ceremonies and followed rules that were enforced by the society's officers, which could even include beatings. Initiation involved signing a pledge in red ink and drinking a Bloody Mary, a cocktail made with tomato juice. Some nonmembers are said to have believed that the drink was made with real human blood, perhaps an understandable misapprehension given the Pyrates's mockpiratical rituals and their reported use of violence for disciplinary purposes. ${ }^{9}$

During the 1970s, there was a growth in student confraternities that had a direct genealogical connection to the Pyrates. In 1971 or 1972 (sources vary on the date) an internal disagreement led to a dissident group leaving or being expelled from the Pyrates and founding a new confraternity known as the Buccaneers. ${ }^{10}$ Thereafter, at a time when student numbers were increasing rapidly, there were further splits. Many of the new groups continued to show an ideological orientation, like the Black Axe, a group aligned with the fashionable philosophy of black consciousness. ${ }^{11}$ The new confraternities, like their forebears, continued to regard themselves as fighters for justice. ${ }^{12}$

It was not only Nigerian campuses that were changing radically during these years, but society as a whole. The 1967-1970 civil war, successive military coups after 1966 and the development of an oil industry that had not existed when the Pyrates was established all contributed to a loss of the relative aura of innocence that had surrounded the Pyrates's early years. The rise of new student confraternities was part of a vogue for new civic and philosophical associations more generally. Many of the new associations and social clubs that were established in these years reflected people's attempts to address the problems of life in Nigeria's burgeoning cities, such as the burial societies and other mutual help societies that, in the absence of affordable commercial insurance, were a means of spreading risk. ${ }^{13}$ Since many parts of Nigeria have the tradition of initiation societies, the plethora of new societies that came into existence in the 1970s no doubt owed something to people's general familiarity with the idea of social action through membership of a specific group. 'Social clubs', notes one writer, 'may be regarded as open and more practical versions' of the initiation societies that have such a long and important history. ${ }^{14}$

Sites of new forms of sociability and new ideologies, Nigeria's new university campuses also witnessed the rise of new religious groups. Most notable were the new Pentecostal churches that constituted autonomous spaces of reli-

$9 \quad$ Ben Oguntuase, interviewed in Punch, 8 August 1999.

10 Offiong, Secret Cults in Nigerian Tertiary Institutions, p. 54.

11 Ibid., p. 69.

12 Ibid., pp. 56-59.

13 Elechi Amadi, Ethics in Nigerian Culture (Heinemann Educational Books, Ibadan, 1982), p. 12.

$14 \quad$ Ibid., p. 13. 
gious practice. Pentecostal student groups emerged as perhaps the most powerful youth movement the country had seen since independence, to the extent that they soon eclipsed the secular student movement. The universities of Ibadan and Ile-Ife became 'hotbeds of Pentecostalism'. ${ }^{15}$ On campuses with a significant presence of Muslim students, new Islamic movements became popular too, contesting the sufi brotherhoods that were closely connected to traditional forms of patronage and that young reformers criticized as inconsistent with correct forms of Islamic practice.

Changes in the associational life of millions of Nigerians in the 1970s were inseparable from the country's oil boom. The country's emergence from civil war was accompanied by a rapid growth in oil production. When the Organization of Petroleum Exporting Countries (OPEC) raised its prices fourfold in 1973, Nigeria also witnessed a massive and sudden increase in state revenues. Oil money flowed, generating a mania for wealth. ${ }^{16}$ In the scramble for a part of the oil riches, which were distributed essentially across the state, Nigeria's traditional agricultural staples suffered alarming falls in production. A US diplomat quoted a conversation he had had with Nigeria's top financial civil servant in December 1973, coincidentally the very month of the first OPEC price rise. The American reported his Nigerian interlocutor as acknowledging 'with disarming frankness' that the government 'knows perfectly well that its development policies are contributing to an exacerbation of income disparities in Nigeria, but accepts this as part of the price of rapid development. The next generation [he added] will have to deal with the consequences. ${ }^{17}$ The writer Chinua Achebe, addressing an audience at Lagos University, had a dark foreboding. 'God forbid', he said, 'that we should be the generation that had the opportunity to create Africa's first truly modern state but frittered away the chance in parochialism, inefficiency, corruption and cynicism. ${ }^{18}$

\section{The turn to violence}

Even before oil had become king, Nigerian political parties were, in the words of the military leader Murtala Muhammed, 'in fact little more than armies organized for fighting elections'. Winning elections was 'a life and death strug-

15 Ebenezer Obadare, 'White-collar fundamentalism: interrogating youth religiosity on Nigerian university campuses', Journal of Modern African Studies, 45, 4, 2007, p. 521.

16 Andrew H. Apter, The Pan-African Nation: Oil and the spectacle of culture in Nigeria (Chicago University Press, Chicago, 2005), esp. chap. 1.

17 National Archives of the United Kingdom, Kew, FCO 65/1529: draft dated 6 December 1973.

18 Daily Times, 20 January 1977, p. 25. 
gle'. ${ }^{19}$ The advent of expensive oil only heightened this effect. Control of the revenues was concentrated at the core of the state, which received the royalties and taxes from oil. The soldiers who controlled the state from 1966 to 1979, and the civilian 'super permanent secretaries' who were so influential in the Federal Military Government, decided who received what, when and how. When the country finally returned to civilian rule after the 1979 elections, there was a further expansion of the state patronage system that was based increasingly on oil wealth. A rapid fall in the price of oil in the early 1980s, for which the government had made no provisions, resulted in a political crisis. The inevitable military coup came on 31 December 1983.

It is generally agreed that the oil boom of the 1970s, followed by the sudden puncturing of the economic bubble created by high prices, transformed Nigerian society. A population whose ambitions had been stimulated by oil money was cruelly disappointed by its sudden disappearance. It was in this period that, by most accounts, Nigeria began to acquire an ugly reputation as the home of the international advance-fee frauds known as ' $419{ }^{\prime} .{ }^{20}$ A later head of Nigeria's anti-corruption agency, Nuhu Ribadu, was to state with regard to the civilian government of 1979-83:

Let us call a spade a spade. This is the period when we started hearing about 419 , it is the period we started having drug problems. It is a period when Majors (in the army) started buying property in London. ${ }^{21}$

This was also the period when there was a disturbing turn in the behaviour and reputation of the student confraternities that had flourished within the wider student movement in more optimistic times. Some of the new confraternities, like the Vikings, continued to give themselves names redolent of the original Pyrates and its offshoot, the Buccaneers. The latter spawned the Black Axe, soon joined by the Red Beret and many other newcomers. Holding their meetings at night and in secret, some of the new groups became associated with the rising number of violent attacks on university campuses. Their behaviour moved far beyond the light-hearted mock-sinister that had been the original style of the Pyrates. There were increasingly incidents of student clubs inflicting serious bodily harm on members as punishment or in the course of initiation ceremonies, fighting with rivals on campus, and being associated with violence generally. One ex-member of a student group recalled initiation as consisting of three weeks of what he called 'rigorous and heartbreaking activities', whose

19 Quoted in Richard A. Joseph, Democracy and Prebendal Politics in Nigeria (Cambridge University Press, Cambridge, 1987), p. 39.

20 cf. Harvey Glickman, 'The Nigerian “419”' advance fee scams: Prank or peril?', Canadian Journal of African Studies, 39, 3 (2005), p. 472.

21 Speech delivered on 19 January 2006: Punch, 20 January 2006. 
purpose was 'to toughen the heart of the otherwise innocent looking boy', ${ }^{22}$ similar to basic military training or initiation into one of the traditional secret societies that have been powerful in Nigeria since pre-colonial times. During their induction ceremonies, many of the new confraternities made use of religious objects, universally referred to in Nigeria as juju, which further strengthened the resemblance with initiation into a traditional power society. So worrying did campus violence become that the Pyrates leadership announced its intention to withdraw from university campuses entirely and to relaunch the group as an adult society called the National Association of Sea Dogs. This it did, but in reality student Pyrates continued to operate on Nigerian campuses, disregarding its national leadership.

Nevertheless, there were people who took quite a positive view of what were now becoming called 'campus cults', recalling their origins in the idealism and social activism of an earlier generation. Philip Aghedo, a member of the Buccaneers for some fifteen years after being introduced by his uncle at the University of Benin in 1981, maintained that, in his day, candidate members of the Buccaneers were vetted for their intelligence and good behaviour before being invited to join. Aghedo stated with regard to the student confraternities:

They train you to be useful to yourself and the society because the thinking governing conduct of the cult is that there must be somebody controlling the environment otherwise the environment will be controlling itself and there could be anarchy. If the cults fail to exercise some level of control in University, the lecturers and administrators can do whatever they like and get away with it. ${ }^{23}$

He attributed the violent clashes that occurred between rival groups to the fact that they were competing with each other in the unregulated social environment formed by students on campus.

In 1999, a single incident attracted the attention of the government and the media to just how serious the rivalries on university campuses had become. At Obafemi Awolowo University in Ile-Ife, a forty-strong war party from the Black Axe confraternity, some of them armed with machine-guns, attacked leaders of the student union who had complained to the university authorities about the cultists' activities. The five or more fatalities included the university's chief security officer. There were suspicions that the murderous activities of the Black Axe might have been associated with outside forces that had an interest in asserting control on the university campus. Groups like the Black Axe at Ile-Ife were recruiting local thugs to provide themselves with extra manpower to reinforce their presence in inter-group conflicts. They were also visiting herbalists

'Cultists confess at Fedpoly, Nekede', Nigerian Tribune, 14 September 1999.

23 '5 million cultists on the loose', Daily Times, 18 July 1999. 
in search of powerful amulets to protect themselves in fights, thus coming into contact with networks influential in a wider criminal and political underworld. ${ }^{24}$ It was often said that the membership of campus cults was drawn disproportionately from children from elite families. The respected former vice-chancellor of Ibadan, Professor Ayo Banjo, noted that the leaders of confraternities or cults on campus - it is hard to know what to call them at this stage of their existence - systematically targeted first-year students from rich families, attempting to recruit them as part of a long-term strategy to strengthen their social networks. A common technique was for the leaders of a campus cult to invite a freshman to join an innocuous-sounding club. If the newcomer showed interest, he was subjected to increasing degrees of intimidation and blackmail, including kidnapping and physical violence, in an effort to coerce the recruit into full membership. ${ }^{25}$

\section{Cults and student politics}

The shocking Ile-Ife killings, occurring shortly after Nigeria's return to civilian government after an almost unbroken fifteen years of military rule, stimulated widespread public debate. Discussion soon spread from the campus cults themselves to the wider social environment in which they had arisen. It was generally recognized that the degeneration from student activism to murderous gangsterism was a reflection of the moral condition of the nation. Among those who have investigated campus cults, there is a consensus that the transformation from student activism to something less social and more violent was a development inseparable from wider tendencies in Nigerian society.

More specifically, the degeneration from confraternity to cult was a consequence of the policies adopted by some of the military governments that dominated Nigeria with only brief interruption from 1966 to 1999. General Obasanjo's banning of the National Union of Nigerian Students during his first period as head of state between 1976 and 1979 was the first of several attempts by the military to assert control over the universities. Even in secondary schools, there were cases of military governments drafting soldiers to work as teachers in an attempt to impose a military discipline on impressionable young minds. Former Buccaneer Philip Aghedo believed that the military, sent to institutions of learning in various capacities, 'unwittingly taught the youngsters the art of weapon handling and management ${ }^{, 26}$ Professor Ayo Banjo has broadly agreed with this analysis, noting that many cultists 'admired the machismo of the tough military men, who ordered things to be done with immediate effect

24 Gabriel Osu, 'Stamping cults from our campuses', Vanguard, 30 August 1999.

25 Rotimi Oyedanmi, 'How to tackle cultism menace', Guardian, 6 January 2000.

26 '5 million cultists on the loose', Daily Times, 18 July 1999. 
and brutally swept all obstacles out of their way,. ${ }^{27}$ Still more damagingly, military governments sometimes gave covert support to campus groups as a means of destabilizing student unions, which were feared by the military men on account of their political radicalism. ${ }^{28}$ In 1991, for example, during the rule of the Machiavellian General Ibrahim Babangida, student cults were used to destabilize student organizations on the Ile-Ife campus that had been agitating for improved bursaries. ${ }^{29}$ University administrators, often appointed for their loyalty to the military government rather than for any academic or managerial qualifications, played one faction off against another among the students at their institutions. Secretive confraternities were instruments in the hands of vicechancellors concerned primarily with political control of their campuses.

In these circumstances during the last two decades of the twentieth century when Nigeria was dominated by military governments with a general contempt for education combined with a fear of student radicalism, the campus confraternities were able to use violence and manipulation to become kingmakers in student politics. The rewards could be quite substantial for aspiring entrepreneurs of power and violence. Some youngsters became professional students, staying on campus year after year, collecting protection money and building up powerful personal followings. Once student associations had become not only politicized but also militarized, it was a short step to their being used for instrumental purposes in personal quarrels. Wole Soyinka notes the case of a university vice-chancellor who used one student confraternity or cult as a personal strong-arm squad to attack faculty members opposed to him. ${ }^{30}$ By 2002, there were reports of former cult members being recruited by an incumbent state governor in the southeast, where shrines and secret societies play a key role in a particularly thuggish political system, as do goon-squads acting on behalf of politicians and even businesspeople. ${ }^{31}$ Some cultists, having made connections with politicians and other powerbrokers during their time in student politics, have gone on to pursue careers in politics, government or the professions, while retaining their membership of their society. This means that some campus cults have developed into networks of influence that pervade wider sections of soci-

27 Oyedanmi, 'How to tackle cultism menace', Guardian, 6 January 2000.

28 See the round-table discussion published in Vanguard, 20-21 September 1999. On the anti-student politics of the military, Patrick Wilmot, Nigeria: The nightmare scenario (Interventions VI, Bookcraft and Farafina, Ibadan and Lagos, 2007).

29 Round-table discussion in Vanguard, 20-21 September 1999.

30 Soyinka, Cults, p. 30.

31 Nduka Nwosu, 'Assassination, a new culture in Igboland', Guardian, 2 November 2002. On the role of shrines in local business, politics and crime, Stephen Ellis, 'The Okija shrine: Death and life in Nigerian politics', Journal of African History, 49, 3, 2008, pp. 445-466. 
ety. But they remain oriented to the interests of their members rather than to any wider social project. This is in contrast to the original Pyrates Confraternity, which aspired to pursue what its members perceived to be a progressive agenda for the improvement of society as a whole. Members of the Black Axe and no doubt some other groups are to be found as far away as the Netherlands, enmeshed in a small and often vulnerable Nigerian diaspora.

Perhaps the ultimate transformation of student confraternities into violent gangs has taken place in the Niger Delta, where a complex low-intensity war is involving dozens of armed factions. Researchers have identified over a hundred specific armed groups, many of them descended from university societies or modelled on them, ${ }^{32}$ administering secret oaths of allegiance and relying heavily on violence. Alongside these - or perhaps intertwined with them, much as the original campus confraternities were intertwined with the official student unions - are militant groups that cultivate a more conventional guerrilla image, like the Niger Delta People's Volunteer Force (NDPVF) or the Movement for the Emancipation of the Niger Delta (MEND) that have conducted an armed campaign that has at times pitted them against the state and the oil companies. In the micropolitics of the federal and state government, the oil companies and local interest groups, shifting allegiances may cause some cults to become affiliated to larger groups, and even to work as enforcers for politicians, particularly during election campaigns.

In the convoluted and violent politics of the Niger Delta, the main distinction between the different types of organization is the quality of the individual allegiance prevailing within them. In the case of a cult, initiation is deemed to be for life and individuals seeking to renounce their allegiance may be subject to drastic punishment. Some of the cults operating in the Niger Delta are reported to have initiation rituals that can even include the murder of a member of the recruit's own family. Membership of such cults may range from a couple of dozen to several thousands. Some are pro-state or pro-government; some are anti-state, while others have no clear political objectives. ${ }^{33}$ Individual organizations can be placed on a spectrum going from groups with political aims to purely criminal associations. At various times, their main occupations might be fighting each other for turf (necessary for access to oil-smuggling routes or other forms of enrichment), peddling the cocaine that is imported in bulk to pay for smuggled oil, and working for politicians as enforcers. Many of them make

32 Eghosa Osaghae, Augustine Ikelegbe, Omobolaji Olarinmoye and Steven Okhomina, 'Youth militias, self determination and resource control struggles in the NigerDelta region of Nigeria', unpublished study, Consortium for Development Partnerships, 2007.

33 Ibid. 
more or less explicit use of techniques of spiritual protection, such as bulletproof charms and amulets.

In June 2004, the Nigerian government passed a law known as the Secret Cult and Similar Activities Prohibition Act that banned some one hundred named groups. ${ }^{34}$ Others not named by the Act continued to exist and be involved in criminal activities. A former student cult member, looking back some years previously on his experiences, did not exaggerate when he noted: 'It has ceased to be play. It is war. ${ }^{35}$

\section{Society and anti-society}

Initiation societies are a historically ingrained form of organization, particularly in southern Nigeria, and in pre-colonial times they played a key role in governance. In some circumstances these societies constituted a check on the power of the chiefs and kings and they often played a role in the administration of justice, and sometimes in commerce and trade. Under colonial rule, which was imposed in Nigeria during the twentieth century, the position of traditional initiation societies was distinctly ambiguous. At one and the same time, the logic of the British system of Indirect Rule was to reinforce institutions that played an established role in local government but also to treat these same institutions with a degree of hostility on account of their lack of transparency and their association with practices deemed by the colonial authorities to be unacceptable, including enslavement and various types of judicial killing. In fact, some traditional initiation societies continued to flourish during colonial times and played an important role in early nationalist politics. ${ }^{36}$

Since the 1950s, growing corruption in Nigerian politics, fuelled by vast oil wealth, has created an environment in which traditional or not-so-traditional secret societies have been able to flourish as lynch-pins of patrimonial politics in a complex system whereby the formal, legal dispositions of state power are intertwined with informal networks, some of them regulated in time-honoured fashion via the institutions of traditional religion. ${ }^{37}$ Senior politicians and officials may, in addition to the public office they hold, also have a status within formal but nonetheless unpublicized organizations, ranging from traditional shrines to international networks such as the Freemasons or the Rosicrucians. Such networks are considered not only as a useful means of dispensing political patronage but, in many cases, also as channels for attaining esoteric power.

4 See Annex.

35 Olugbile, 'Cult fever', Vanguard, 15 August 1999.

36 Cf. Tekena Tamuno \& Robin Horton, 'The changing position of secret societies and cults in modern Nigeria', African Notes, 5, 2 (1969), pp. 36-62.

37 Cf. Ellis, 'The Okija shrine'. 
More than thirty years ago, the Nigerian government professed itself to be greatly perturbed by the existence of secret societies that were judged to be pervasive in places of public employment, including the civil service and the army. The army chief of staff was quoted as describing secret societies as 'a cancer which has eaten deep into all ranks of the Nigerian army'. ${ }^{38}$ They were also said to have penetrated the ranks of High Court judges, the police, and even church leaders. In July 1977, the Federal Military Government issued a formal ban on public servants joining secret societies, concerned by evidence that members of secret societies protected one another and helped each other achieve positions of influence. ${ }^{39}$ It was apparently as a consequence of this blanket ban on secret societies that the Pyrates was banned on some campuses: some fifteen students, for example, were arrested at the University of Calabar and the Calabar College of Technology in 1977 for being members of the Pyrates. ${ }^{40}$ In general, however, the government's official hostility to secret societies at that time was not directed principally towards the universities where such bodies were in their infancy and not yet deemed to be a public nuisance, but towards the civil service and other branches of the state.

In view of this history, the story of Nigeria's campus cults needs to be understood in a broader social and political perspective. This includes an appreciation of how the country's political and civil society has been influenced by closed associations or initiation societies, and how these have been used or abused over a long period by politicians and others avid for power. As one journalist correctly observed, 'it is ... rather hypocritical that that society condones savage tendencies within itself while wishing the campuses to eradicate these same tendencies'. ${ }^{41}$ Although certain key moments can be identified in this longer history of the coexistence of different forms of power, it has been, in retrospect, quite a steady process. While the colonial government banned certain traditional societies and shrines on the grounds of their association with such criminal practices as enslavement or the taking of human life, many such institutions in fact continued surreptitiously, existing within the bowels of Indirect Rule. Post-colonial governments in Nigeria, like their colonial forebears, sometimes declared themselves shocked to discover the degree to which institutions of state that had been conceived in the formal mode proper to a modern nation-state had in fact been infiltrated by networks of power with a different pedigree and no legal standing. From time to time, a scandal exposes this imbrication of different channels and practices of power to public view, and politicians duly call for the law to be enforced in all its majesty. But implementing

38 Quoted in Tai Solarin, 'Belief in secret cults', Nigerian Tribune, 16 February 1976.

39 Amadi, Ethics in Nigerian Culture, p. 8.

40 Daily Times, 27 January 1977.

${ }^{41}$ Quasim Odunmbaku, ‘A tale of two cults', This Day, 17 August 1999. 
the law, even when appropriate, is extraordinarily difficult when it comes to dealing with secretive networks that have penetrated the state itself and that may be ruthless in their mode of operation.

The July 1977 ban on secret societies, announced at the height of Nigeria's first and most lethal oil boom, marked the point when government at its most senior level officially became concerned by the influence of secret societies. This was also the period when student confraternities were beginning to proliferate following the initial split of the Buccaneers from the Pyrates, the first of many organizations to be spawned in this way. Furthermore, it was the first period of spiritual awakening on the university campuses that had proliferated in the previous decade. The campuses became the mainspring of the Pentecostalist movement that has become so widespread and influential throughout Nigerian society. It was in the mid 1970s that Reverend Benson Idahosa, who was later to become the most famous of all Nigerian Pentecostalist preachers and the founder of a university that bears his name, first held services of cleansing for members of secret societies. ${ }^{42}$ It is not just that the Pentecostalists and the cultists happened to be expanding their activities during the same period. Instead, there is an intimate connection between the two as they competed not only for the bodies but also the souls of students in their formative years, and the nation's future elite. In Pentecostal theology, the fight with the cultists is a battle with the forces of Satan and of darkness that threaten Nigeria. In the vocabulary of the social sciences, it is a struggle between a broad social movement on the country's university campuses that is oriented towards self-improvement and social action by means of both student unions and religious groups versus the activities of clandestine groups that have become dedicated to the narrow self-interest of their members and that are the very opposite of a social movement. The competition between these forces has been manipulated by powerful people, including military governments concerned with defending themselves against student radicalism and demobilizing social movements of many sorts, and also unscrupulous university administrators and even academic staff concerned with protecting their position within their institutions. Since Nigerians generally consider power not only in material terms but also in spiritual ones, the conflict between Pentecostalism and secret societies, even those with no apparently religious leaning, is couched in theological rhetoric. At stake are the hearts and minds of Nigeria's future ruling class.

The contests between rival networks of power and their religious, political and legal dimensions also reflect different visions and traditions of social action. Nigeria has a liberal constitution that provides for political expression through the conventional channels of party politics and parliamentary represen-

42 Yemi Folarin, 'Cults' secret out', Daily Express, 8 September 1977. 
tation. At various times in the past, both under colonial rule and subsequently, large numbers of Nigerians have mobilized for political purposes in forms usual in liberal democracies, through trade unions, public-interest groups and so on. Military governments in particular often abhorred such activity, which could easily have threatened their own existence, and took steps to make social mobilization as difficult as possible. The closed and hidden groups of various sorts, ranging from simple personal networks to organized groups such as traditional initiation societies, religious networks and student confraternities, were sometimes used for this purpose. In passing, it should be remembered that the constitution explicitly bans secret societies. ${ }^{43}$

The fact that initiation societies have historically existed in southern Nigeria does not mean that the presence of quasi-traditional groups will always be felt. Such groups have been encouraged and instrumentalized for specific reasons, sometimes by the country's most powerful rulers. Nigeria is what it is today in the twenty-first century as a consequence of these actions, not simply because of the legacy of history.

It is interesting to note that most reports of student cults emanate from southern Nigeria, which is also the area where initiation societies were most powerful in pre-colonial times. However Wole Soyinka, in characteristically combative style, has attacked the notion that student cults are less rampant in the north than the south. He quotes the case of the Gamji cult, which is said to have been favoured by senior figures in Northern Nigeria, and manipulated by General Abacha in his bid to prolong his tenure of power in the $1990 \mathrm{~s} .{ }^{44} \mathrm{He}$ also points to the existence of the so-called 'Kaduna mafia', ${ }^{45}$ the grouping of northern potentates often regarded as perhaps the most important enduring informal structure of power in Nigeria. However, while Soyinka's examples demonstrate that Northern powerbrokers are adept at forming discreet associations to further their collective interests, he does not demonstrate that universities in Northern Nigeria are as likely as Southern institutions to host student 'cults'. This apparent difference appears to reflect the distinctive historical trajectories of state formation in the North and South. Broadly speaking, the favoured strategy for two centuries of pursuing political hegemony in Northern Nigeria has been via the language and organizational structures associated with Islam, and this has served many Northern elites well. Since the establishment of Nigeria by British decree in 1914, Southern elites have generally found it more difficult to establish a hegemonic position. Individuals have often had recourse to unofficial power structures, such as secret societies, to advance their position. Although

43 Section 38, sub-section 4 of the Constitution of the Federal Republic of Nigeria (1999). The full text is available at www.nigeria-law.org.

44 Soyinka, Cults, p. 78.

45 Ibid. 
they have been generally successful in this undertaking at regional or local level, Southern Nigerian politicians have generally been unsuccessful in establishing a hegemonic position that would enable them to challenge the Northern grip on the power of the Nigerian state. Moreover, the imbrication of official and unofficial networks has resulted in enormous bureaucratic inefficiencies and has led to widespread demoralization. New religious movements in both North and South Nigeria represent campaigns not only of spiritual renewal but also the creation of spaces of autonomous action intended to be free from the moral complexities engendered by Nigeria's politics over the last fifty years. ${ }^{46}$

The analogy made by one journalist is very apt: 'Cultism is to the cultists what plotting is to the military [:] top secret' ${ }^{47}$ Particularly under General Ibrahim Babangida (1985-1993), Nigeria was subject to a style of rule whereby 'direct disbursals and administrative favours were increasingly supplanted by politically-influenced arbitrage in a variety of domestic markets', a process more simply described as 'zaïrianization'. ${ }^{48}$ Nigeria's recent history has been one of social fragmentation that at times has been the deliberate strategy of elites insecure in their legitimacy. It has also been the instrument of less powerful citizens who have discovered that attachment to particular networks, including those in the form of a secret society, is an outstanding way of obtaining a slice of the national cake, which is the summit of Nigerian political activity. Far from being immune to this process, the universities, as a breeding ground of the national elite, have been important sites. It is small wonder that the movements with nationwide social aspirations that flourished in the first years of nationalism have been snuffed out, to be replaced by the factionalized and particularist politics of networks or by the religious language of renewal articulated by both Islamist and Christian reformers.

46 Cf. Ruth Marshall, Political Spiritualities: The explosion of Pentecostalism in Nigeria (Chicago University Press, Chicago, forthcoming).

47 Bayo Oguntunase, 'The problems of cultism in Nigeria (1)', National Concord, 29 June 1998.

48 Peter Lewis, 'From prebendalism to predation: The political economy of decline in Nigeria', Journal of Modern African Studies, 34, 1, 1996, p. 97. The reference to 'zaïrianization' is on page 80 . 


\section{Annex}

List of groups banned under the Secret Cult and Similar Activities Prohibition Law $2004^{49}$

\begin{tabular}{|c|c|c|}
\hline Agbaye & Eagle Club & Neo-Black Movement \\
\hline Airwords & Egbe Dudu & Night Mates \\
\hline Amazon & Eiye of Air Lords & Nite Hawks \\
\hline Baccaneers (Sea Lords) & Fraternity & Nite Rovers \\
\hline Barracuda & Elegemface & Odu Cofraternity \\
\hline Bas & Executioners & Osiri \\
\hline Bees International & Fangs & Ostrich Fraternity \\
\hline Big 20 & $\mathrm{FF}$ & Panama Pyrate \\
\hline Black Axe & Fliers & Phoenix \\
\hline Black Beret Fraternity & Frigates & Predators \\
\hline Black Brasserie [sic] & Gentlemen's Club & Red Devils \\
\hline Black Brothers & Green Berets Fraternity & Red Fishes \\
\hline Black Cats & Hard Candies & Red Sea Horse \\
\hline Black Cross & Hell's Angels & Royal House of Peace \\
\hline Black Ladies & Hepos & Royal Queens \\
\hline Black Ofals & Himalayas & Sailors \\
\hline Black Scorpions & Icelanders & Scavengers \\
\hline Black Sword & Jaggare Confederation & Scorpion \\
\hline Blanchers & KGB & Scorpion \\
\hline Black Bras & King Cobra & Scorpion Fraternity \\
\hline Blood Suckers & KlamKonfraternity & Sea Vipers \\
\hline Brotherhood of Blood & Klansman & Soiree Fraternity \\
\hline Burkina Faso: Revolution & Ku Klux Klan & Soko \\
\hline Fraternity & Knite Cade & Sunmen \\
\hline Canary & Mafia Lords & Temple of Eden Fraternity \\
\hline Cappa Vandetto & Mafioso Fraternity & Thomas Sankara Boys \\
\hline Daughters of Jezebel & Malcolm X & Tikan Giants \\
\hline Dey Gbam & Maphites /Maphlate & Trojan Horses Fraternity \\
\hline Dey Well & Mgba Mgba Brothers & Truth Seekers \\
\hline Dolphins & Mob Stab & Twin mate \\
\hline Dragons & Musketeers Fraternity & Vikings \\
\hline Dreaded Friends of & National Association of & Vipers \\
\hline Friends & Adventurers & Vultures \\
\hline Blood Hunters & National Association of & Walrus \\
\hline & Sea Dogs & White Bishop \\
\hline
\end{tabular}

49 Osaghae et al., 'Youth militias, self determination and resource control struggles in the Niger-Delta region of Nigeria'. 


\section{Bibliography}

Abbink, J., 'Dervishes, moryaan and freedom fighters: Cycles of rebellion and the fragmentation of Somali society, 1900-2000', in J. Abbink et al. (eds), Rethinking Resistance: Revolt and Violence in African History (Brill, Leiden, 2003), pp. 328365.

Adam, Hussein, From Tyranny to Anarchy: The Somali experience (Red Sea Press, Trenton, NJ/Asmara, 2008).

African Women and Peace Support Group, Liberian Women Peacemakers: Fighting for the right to be seen, heard, and counted (Africa World Press, Trenton, NJ, 2004).

Alingué, Madeleine Andebeng L., 'African Transatlantic Resistance and Movements', in Atilio Boron \& A. Gladys Lechini (eds), Politics and Social Movements in an Hegemonic World: Lessons from Africa, Asia and Latin America (Consejo Latinoamericano de Ciencias Sociales (CLACSO), Buenos Aires, 2005), pp. 245258.

Amadi, Elechi, Ethics in Nigerian Culture (Heinemann Educational Books, Ibadan, 1982).

Amadiume, Ifi, 'Gender, political systems and social movements: A West African experience', in Mamdani \& Wamba-dia-Wamba (eds), African Studies in Social Movements (Codesria, Dakar, 1995), pp. 35-68.

Amisi, B. \& R. Ballard, 'In the absence of citizenship: Congolese refugee struggle and organisation in South Africa', in Richard Ballard, Adam Habib \& Imraan Valodia (eds), Voices of Protest: Social movements in post-apartheid South Africa (University of KwaZulu-Natal Press, Pietermaritzburg, 2006), pp. 397-412.

Amnesty International, Mauritania: A future free from slavery? (Amnesty International, London, 2002).

Anderson, B., Imagined Communities: Reflections on the origin and spread of nationalism (Verso, London, 1983).

Anheier, Helmut, Marlies Glasius \& Mary Kaldor, 'Introducing global civil society', in H. Anheier, M. Glasius \& M. Kaldor (eds), Global Civil Society (Oxford University Press, Oxford, 2001), pp. 3-22.

Apter, Andrew H., The Pan-African Nation: Oil and the spectacle of culture in Nigeria (Chicago University Press, Chicago, 2005).

Atieno, Awinda, 'Mungiki, 'neo-Mau Mau' and the prospects for democracy in Kenya', Review of African Political Economy, 34, 13 (2007), pp. 526-531.

Bales, Kevin, Disposable People: New slavery in the global economy (University of California Press, Berkeley, CA, 1999).

Ballard, Richard, Adam Habib, Imraan Valodia \& Elke Zuern, 'Globalization, marginalization and contemporary social movements in South Africa', African Affairs, 104, 417 (2005), pp. 615-634.

Ballard, Richard, Adam Habib \& ImraanValodia, 'Social Movements in South Africa: Promoting crisis or creating stability', in V. Padayachee (ed.), The Development Decade (HSRC Press, Cape Town, 2006), pp. 397-412.

Ballard, Richard, Adam Habib \& Imraan Valodia (eds), Voices of Protest: Social movements in post-apartheid South Africa (University of Kwazulu-Natal Press, Pietermaritzburg, 2006). 
Bate, S., 'One mission, two churches: the Catholic church in southern Africa, 19471997', in J .Brain \& P. Denis (eds), The Catholic Church in Contemporary Southern Africa (Cluster, Pietermaritzburg, 1999), pp. 5-36.

Bauer, Gretchen \& Hannah E. Britton, 'Women in African parliaments: a continental shift?', in G. Bauer \& H.E. Britton (eds), Women in African Parliaments (Lynne Rienner Publications, Boulder, Col., 2006), pp. 1-30.

Bayart, Jean-François, 'Africa in the world: A history of extraversion', African Affairs, 99, 395 (2000), pp. 217-267.

Baxter, Joan, “Another Africa is possible': Social movements organize to challenge dominant economic policies', Africa Recovery, 16, 1, (2002), p. 18.

Benford, R. 'An insider's critique of the social movement framing perspective', Sociological Inquiry, 67, 4 (1997), pp. 409-430.

Bledsoe, Caroline H., 'Stratification and Sande politics', Ethnologische Zeitschrift Zürich, 1 (1980), pp. 143-150.

Bledsoe, Caroline H., 'The political use of Sande ideology and symbolism', American Ethnologist, 11 (1984), pp. 455-467.

Bledsoe, Caroline H., Women and Marriage in Kpelle Society (Stanford University Press, Stanford, 1980).

Blumer, H.G., 'Collective behavior', in A. McClung Lee (ed), Principles of Sociology (Barnes and Noble Books, New York, 1969), pp. 67-121.

Bond, Patrick, Elite Transition: From apartheid to neoliberalism in South Africa (Pluto, London, 2000).

Bond, Patrick, 'Strategies for Social Justice Movements from Southern Africa to the United States', Foreign Policy In Focus (FPIF), 20 January, 2005.

Bond, Patrick, Fanon's Warning: A civil society reader on the new partnership for Africa's development (Africa World Press, Trenton, NJ, 2005).

Bosgra, Sietse, 'From Jan van Riebeeck to solidarity with the struggle: The Netherlands, South Africa and apartheid', in SADET (South African Democracy Trust), The Road to Democracy in South Africa, vol. 3, part I, pp. 905-933.

Botte, Roger, 'De l'esclavage et du daltonisme dans les sciences sociales. Avantpropos', Journal des Africanistes, 70, 1-2 (2000), pp. 7-42.

Boyd, B., G.G. Dess \& A. Rasheed, 'Divergence between archival and perceptual measures of the environment: causes and consequences,' Academy of Management Review, 18, 2 (1993), pp. 204-226.

Bratton, M. \& N. van de Walle, 'Neopatrimonial regimes and political transitions in Africa', MSU Working Papers on Political Reform in Africa, Working Paper No. 1 (Department of Political Science, East Lansing, MI, 1993).

Bratton, M. \& N. van de Walle, Democratic Experiments in Africa: Regime transitions in comparative perspective (Cambridge University Press, Cambridge, 1997).

Brinkman, Inge, 'Angolan civilians in wartime, 1961-2002', in John Laband (ed.), Daily Lives of Civilians in Wartime Africa: From slavery days to the Rwandan genocide (Greenwood Press, London, 2007), pp. 169-194.

Bryden, Matt, 'No quick fixes: coming to terms with terrorism, Islam and statelessness in Somalia', Journal of Conflict Studies, 23, 2 (2003), pp. 24-56.

Buhlungu, S., 'Upstarts or bearers of tradition? The anti-privatisation forum of Gauteng', in Richard Ballard, Adam Habib \& Imraan Valodia (eds), Voices of Protest: Social movements in post-apartheid South Africa (University of KwaZuluNatal Press, Pietermaritzburg, 2006), pp. 67-87. 
Bullard, Alice, 'From colonization to globalization: the vicissitudes of slavery in Mauritania', Cahiers d'études africaines, 179-180 (2005), pp. 751-769.

Burawoy, M., 'For a sociological Marxism: The complementary convergence of Antonio Gramsci and Karl Polanyi’, in Politics and Society, 31, 2 (2003), pp. 193-261.

Casey, Conerly, 'Marginal Muslims: Politics and the perceptual bounds of Islamic authenticity in northern Nigeria', Africa Today, 54, 3 (2008), pp. 67-92.

Cassanelli, Lee V., The Shaping of Somali Society: Reconstructing the history of a pastoral people, 1600-1900 (University of Pennsylvania Press, Philadelphia, 1982).

Castells, M., The Rise of the Network Society (Blackwell Publishers, Oxford, 1996).

Chakanza, J., 'The pro-democracy movement in Malawi: The Catholic Church's contribution', in M. Nzunda \& K. Ross (eds), Church, Law and Political Transformation in Malawi, 1992-1994 (Mambo Press, Gweru, 1995), pp. 8-14.

Chirwa, W., 'Civil society in Malawi's democratic politics,' in M. Ott, K. Phiri \& N. Patel (eds), Malawi's Second Democratic Elections: Process, problems and prospects (Kachere, Zomba, 2000), pp. 87-119.

Clark, J., Global Civic Engagement (Earthscan, London, 2003).

Cock, J., 'Connecting the red, brown and green: the environmental justice movement in South Africa', in Richard Ballard, Adam Habib \& Imraan Valodia (eds), Voices of Protest: Social movements in post-apartheid South Africa (University of KwaZuluNatal Press, Pietermaritzburg, 2006) pp. 203-224.

Cohen, Abner, Custom and Politics in Urban Africa: A study of Hausa migrants in Yoruba towns (Routledge \& Kegan Paul, London, 1969).

College, K., Trade Unions and the Struggle for Quality Services in Malawi (PSI, Johannesburg, 2004).

Collier, Paul (ed.), 'Economic causes of civil conflict and their implications for policy', in The Bottom Billion: Why the poorest countries are failing and what can be done about it (Oxford University Press, Oxford, 2007).

Comaroff, Jean \& John Comaroff, 'The struggle between the constitution and "things African", in The Wiser Review (July 2004), pp. 6-7.

Comaroff, John \& Jean Comaroff, 'Reflections on liberalism, policulturalism \& IDology: Citizenship \& difference in South Africa', in Steven Robins (ed.), Limits to Liberation after Apartheid: Citizenship, governance and culture (James Currey, Oxford, 2005), pp. 33-56.

Commission Nationale des Droits de l'Homme, Rapport Annuel 2007-2008 (CNDH, Nouakchott, June 2008).

Conteh-Morgan, Earl, Democratization in Africa: The theory and dynamics of political transitions (Praeger, London, 1997).

Coton, Samuel, Silent Terror: A journey into contemporary African slavery (Harlem River Press, New York, 1998).

Cramer, Christopher, Civil War is not a Stupid Thing: Accounting for violence in developing countries (Hurst and Co., London, 2006).

Crousse, Bernard, 'La réforme foncière mauritanienne de 1983, étatisation ou individualisation', Politique africaine, 21 (March 1986), pp. 63-76.

Cullen, T., Malawi: A Turning Point (Pentland Press, Durham, 1994).

Danmole, H.O. 'Religious encounter in southwestern Nigeria: The domestication of Islam among the Yoruba', in Jacob K. Olupona \& Terry Rey (eds), Orisa Devotion 
as World Religion: The globalization of Yoruba religious culture (University of Wisconsin Press, Madison, 2008), pp. 202-220.

David, Soniia, "You become one in marriage": Domestic budgeting among the Kpelle of Liberia', Canadian Journal of African Studies, 30, 2 (1996), pp. 157-182.

D'Azevedo, Warren L., 'Some historical problems in the delineation of a central west Atlantic region', Annals New York Academy of Sciences, 96 (1962), pp. 512-538.

Della Porta, Donatella \& Mario Diani (eds), Social Movements: An introduction (Basil Blackwell, Oxford, 1999).

Della Porta, Donatella \& Mario Diani, Social Movements: An introduction (Blackwell, Malden/Oxford/Carlton, 2nd edition, 2006).

Della Porta, D. \& S. Tarrow (eds), Transnational Protest and Global Activism (Rowman and Littlefield, Lanham, MD, 2005).

Della Porta, D., H. Kriesi \& D. Rucht (eds), Social Movement in a Globalizing World (Macmillan Press, London, 1999).

Desai, A. \& A. Habib, 'Labour relations in transition: the rise of corporatism in South Africa's automobile industry', Journal of Modern African Studies, 35, 3 (1997), pp. 495-515.

Devenish, A. \& C. Skinner, 'Collective action in the informal economy: The case of the self employed women's union, 1994-2004', in Richard Ballard, Adam Habib \& Imraan Valodia (eds), Voices of Protest: Social movements in post-apartheid South Africa (University of KwaZulu-Natal Press, Pietermaritzburg, 2006), pp. 255-277.

Diamond, L., 'Beyond autocracy: prospects for democracy in Africa', in Working Papers for the Inaugural Seminar of the Governance in Africa Program (The Carter Centre of Emory University, Atlanta, GA, 1989).

Diani, M. \& D. McAdam (eds), Social Movement Analysis: The network perspective (Oxford University Press, Oxford/New York, 2003).

Dietrich, Christian, Hard Currency: The criminalized diamond industry of the Democratic Republic of Congo and its neighbours (Partnership Africa Canada, Ottawa, 2002).

Dirsuweit, T., 'The problem of identities: The lesbian, gay, bisexual, transgender and intersex social movement in South Africa', in Richard Ballard, Adam Habib \& Imraan Valodia (eds), Voices of Protest: Social movements in post-apartheid South Africa (University of KwaZulu-Natal Press, Scottville, 2006), pp. 325-347.

Douglas, Farah, Blood from Stones: The secret financial network of terror (Broadway Publishers, New York, 2004).

Dulani, B. \& J.K. van Donge, 'A decade of legislature-executive squabble in Malawi (1994-2004)', in M. Salih (ed.), African Parliaments: Between Governments and Governance (Palgrave Macmillan, London, 2005), pp. 201-224.

Duyvendak, J.W. \& M. Hurenkamp (eds), Kiezen voor de Kudde. Lichte gemeenschappen en de nieuwe meerderheid (Van Gennep, Amsterdam, 2004).

Dwyer, P., 'The concerned citizens forum: A fight within a fight', in Richard Ballard, Adam Habib \& Imraan Valodia (eds), Voices of Protest: Social movements in postapartheid South Africa (University of KwaZulu-Natal Press, Pietermaritzburg, 2006), pp. 89-110.

Dzimbiri, L., 'Democracy and chameleon like leaders', in Kings Phiri et al. (eds), Democratisation in Malawi: A stocktaking (CLAIM, Blantyre, 1998), pp. 87-101.

Egan, A. \& A. Wafer, 'Dynamics of a 'mini mass movement': Origins, identity and ideological pluralism in the Soweto electricity crisis committee', in Richard Ballard, 
Adam Habib \& Imraan Valodia (eds), Voices of Protest: Social movements in postapartheid South Africa (University of KwaZulu-Natal Press, Pietermaritzburg, 2006), pp. 45-65.

Eickelman, Dale F., 'National identity and religious discourse in contemporary Oman', International Journal of Islamic and Arabic Studies, 6, 1 (1989), pp. 1-20.

Eisinger, P. 'The conditions of protest behavior in American cities', American Political Science Review, 67 (1973), pp.11-28.

El-Hor, 'Charte constitutive' (Nouakchott, 5 March 1978) in L'Ouest saharien-Cahiers d'études pluridisciplinaires, 4 (L'Harmattan, Paris, 2004), pp. 183-188.

Ellemers, N., R. Spears \& B. Doosje (eds), Social Identity: Context, commitment, content (Blackwell, Oxford,1999).

Ellis, Stephen, 'The Okija shrine: Death and life in Nigerian politics', Journal of African History, 49, 3 (2008), pp. 445-466.

Ellis, Stephen \& Gerrie ter Haar, Worlds of Power: Religious thought and political practice in Africa (C. Hurst \& Co., London, 2004).

Episcopal Conference of Malawi (ECM), Walking Together in Faith, Hope and Love (Montfort Media, Balaka, 1999).

Episcopal Conference of Malawi (ECM), Living our Faith: Lenten letter of the Catholic bishops to their faithful (Montfort Media, Balaka, 1992).

Eyerman, R. \& A. Jamison, Social Movements: A cognitive approach (Polity Press, Cambridge, 1991).

Falola, Toyin, Violence in Nigeria: The crisis of religious politics and secular ideologies (University of Rochester Press, Rochester, NY, 1998).

Fanon, F., The Wretched of the Earth (Penguin Books, Harmondsworth, 1967).

Feldman, Robert, 'Fund transfers-African terrorists blend old and new: Hawala and satellite telecommunications', Small Wars and Insurgencies, 17, 3 (2006), pp. 356-366.

Feldman, Robert, 'Somalia: Amidst the rubble, a vibrant telecommunications infrastructure', Review of African Political Economy, 113 (2007), pp. 565-572.

Fine, Gary A., 'Public narration and group culture: Discerning discourse in social movements', in H. Johnston \& Bert Klandermans (eds), Social Movements and Culture (University of Minnesota Press, Minneapolis, 1995), pp. 127-143.

Fisher, Humphrey, The Ahmadiyya: A study in contemporary Islam on the West African coast (Oxford University Press for the Nigerian Institute of Social and Economic Research, London, 1963).

Fisher, Ryland, Race (Jacana Publishers, Johannesburg, 2007).

Fraser, Nancy, Justice Interruptus: Critical reflections on the 'postsocialist' condition (Routledge, New York, 1997).

Friedman, S. \& S. Mottiar, 'Seeking the high ground: The Treatment Action Campaign and the politics of morality', in Richard Ballard, Adam Habib \& Imraan Valodia (eds), Voices of Protest: Social movements in post-apartheid South Africa (University of KwaZulu-Natal Press, Pietermaritzburg, 2006), pp. 23-44.

Fuest, Veronika, “A Job, a Shop, and Loving Business”.: Lebensweisen gebildeter Frauen in Liberia (LIT Verlag, Münster, 1996).

Fuest, Veronika, Contexts of Conflict in Southeast Liberia. A study report (Welthungerhilfe, Bonn, 2008).

Fuest, Veronika, "'This is the time to get in front". Changing roles and opportunities for women in Liberia', African Affairs, 107, 427 (2008): pp. 201-224. 
Fuest, Veronika, Fruits of war? Refigurations and contestations of female identities in Liberia. Working Paper of the Max Planck Institute for Social Anthropology (Max Planck Institute for Social Anthropology, Halle/Saale, forthcoming).

Gamson, W.A., Strategy of Social Protest (Wadsworth Publishing, Belmont, CA, 1990). Gamson, W.A., Talking Politics (Cambridge University Press, Cambridge, 1992).

Garrett, R.K., 'Protest in an information society: A review of literature on social movements and new ICTs', Information, Communication, and Society, 9, 2 (2006), pp. 202-224.

Gbadamosi, T.G.O., Growth of Islam among the Yoruba, 1841-1908 (Longman, London, 1978).

Gberie, Lansana, Destabilizing Guinea: Diamonds, Charles Taylor and the potential for wider humanitarian catastrophe (Partnership Africa Canada, Ottawa, 2001).

Gberie, Lansana, War and Peace in Sierra Leone: Diamonds, corruption and the Lebanese connection (Partnership Africa Canada, Ottawa, 2002).

Gberie, Lansana, A Dirty War in West Africa: The RUF and the destruction of Sierra Leone (Hurst and Co., London, 2005).

Gerhards, J. \& D. Rucht, 'Mesomobilization: organizing and framing in two protest campaigns in West Germany', American Journal of Sociology, 98, (1992), pp. 555-596.

Gifford, Paul, Christianity and Politics in Doe's Liberia (Cambridge University Press, Cambridge, 1993).

Gifford, Paul (ed.), The Christian Churches and Democratization in Africa (Brill, Leiden, 1995).

Gilkes, Patrick, 'Briefing: Somalia', African Affairs, 98 (1999), pp. 571-577.

Gill, A., 'Rendering unto Caesar? Religious competition and Catholic political strategy in Latin America, 1962-79', American Journal of Political Science, 38, 2 (1994), pp. 403-425.

Glickman, Harvey, 'The Nigerian “419” advance fee scams: prank or peril?', Canadian Journal of African Studies, 39, 3 (2005), pp. 460-489.

Goodwin, J. \& J.M. Jasper, 'Caught in a winding, snarling vine: The structural bias of political process theory’, Sociological Forum, 14, 1 (1999), pp. 27-54.

Goodwin, J., J.M. Jasper \& F. Polletta, Passionate Politics: Emotions and social movements (The University of Chicago Press, Chicago, IL, 2001).

Government of Liberia, Act to Govern the Devolution of Estates and Establish the Rights of Inheritance for Spouses of Both Statutory and Customary Marriages (Monrovia, 2003).

Greenberg, S., 'The landless people's movement and the failure of post-apartheid land reform', in Richard Ballard, Adam Habib \& Imraan Valodia (eds), Voices of Protest: Social movements in post-apartheid South Africa (University of KwaZuluNatal Press, Pietermaritzburg, 2006), pp. 133-153.

Grosse-Kettler, Sabine, External Actors in Stateless Somalia. A war economy and it promoters. BICC paper 39 (Bonn International Center for Conversion, Bonn, 2004).

Gurr, T., Why Men Rebel (Princeton University Press, Princeton, NJ, 1970).

Gusfield, J., Protest, Reform and Revolt: A reader in social movements (John Wiley, New York, 1970).

Habib, A. 'The politics of economic policy-making: Substantive uncertainty, political leverage, and human development', Transformation, 56 (2004), pp. 90-103. 
Habib, A., 'South Africa: conceptualizing a politics of human-oriented development', Social Dynamics, 34, 1 (2008), pp. 46-61.

Habib, A. \& R. Taylor, 'Political alliances and parliamentary opposition in postapartheid South Africa', Democratization, 8, 1 (2001), pp. 207-226.

Habib, A. \& P. Opoku-Mensah, 'Mobilizing across Africa: civil society and democratisation', in South African Yearbook of International Affairs 2002/03 (South Africa Institute for International Affairs, 2003), pp. 267-274.

Habib, A. \& I. Valodia, 'Reconstructing a social movement in an era of globalisation: A case study of the Congress of South African Trade Unions (COSATU)', in Richard Ballard, Adam Habib \& Imraan Valodia (eds), Voices of Protest: Social movements in post-apartheid South Africa (University of KwaZulu-Natal Press, Pietermaritzburg, 2006), pp. 225-253.

Hackett, Rosalind I.J., 'Managing or manipulating religious conflict in the Nigerian media', in Jolyon Mitchell \& Sophia Marriage (eds), Mediating Religion: Conversations in media, religion and culture (T. \& T. Clark, Edinburgh, 2003), pp. 47-64.

Hackett, Rosalind I.J., 'Radical Christian revivalism in Nigeria and Ghana: Recent patterns of conflict and intolerance', in Abdullahi A. An-Na'im (ed.), Proselytization and Communal Self-Determination in Africa (Orbis Books, Maryknoll, NY, 1999), pp. 246-267.

Haenni, Patrick, Islam de marché: L’autre révolution conservatrice (Seuil, Paris, 2005).

Hahonou, Éric Komlavi, 'Cultures politiques, esclavage et décentralisation. La revanche politique des descendants d'esclaves au Bénin et au Niger', Politique africaine, 111 (2008), pp. 169-186.

Hardt, M. \& A. Negri, Empire (Harvard University Press, Cambridge/Massachusetts, 2000).

Hart, Stephen, 'The cultural dimension of social movements: A theoretical reassessment and literature review', Sociology of Religion, 57, 1 (1996), pp. 87-100.

Harvey, D., The New Imperialism (Oxford University Press, Oxford, 2003).

Hassim, S., 'The challenges of inclusion and transformation: the women's movement in democratic South Africa', in Richard Ballard, Adam Habib \& Imraan Valodia (eds), Voices of Protest: Social movements in post-apartheid South Africa (University of KwaZulu-Natal Press, Pietermaritzburg, 2006).

Haynes, J., 'Religion and democratization in Africa', Democratization, 11, 4 (2004), pp. 66-89.

Hazleton, Ralph, Diamonds Forever or For Good? The economic impact of diamonds in Southern Africa (Partnership Africa Canada, Ottawa, 2002).

Held, D., 'Democracy, the nation-state and the global system', in David Held (ed.) Political Theory Today (Polity Press, Cambridge, 1991), pp. 197-235.

Herrera, Linda \& Asef Bayat (eds), Being Young and Muslim (Oxford University Press, Oxford, forthcoming in 2010).

Higazi, Adam, 'Violence urbaine et politique à Jos (Nigeria), de la période coloniale aux élections de 2007', Politique africaine,106 (2007), pp. 69-91.

Hunt, Swanee \& Cristine Posa, 'Women waging peace', Foreign Policy, May/June (2001), pp. 38-47.

Huntington, S., The Third Wave: Democratization in the late twentieth century (University of Oklahoma Press, Oklahoma, 1991). 
Ibeanu, Okechukwu, 'Healing and changing: the changing identity of women in the aftermath of the Ogoni crisis in Nigeria', in Sheila Meintjes et al. (eds), The Aftermath. Women in post-conflict transformation (Zed Books, London, 2001), pp. 189-209.

Idang, Gordon J., 'The politics of Nigerian foreign policy: the ratification and renunciation of the Anglo-Nigerian defence agreement', African Studies Review, 13, 2 (1970), pp. 227-251.

Immink, B. \& G. Chigona, 'Between apathy and participation: The role of civil society and faith communities', in M. Ott, B. Immink, B. Mhango \& C. Peters-Berries (eds), The Power of the Vote: Malawi's 2004 parliamentary and presidential elections (Kachere, Zomba, 2005), pp. 139-158.

Inglehart, R., The Silent Revolution: Changing values and political styles among Western publics (Princeton University Press, Princeton, NJ, 1977).

International Crisis Group, Somalia: Countering terrorism in a failed state (ICG, Brussels, 2002).

International Crisis Group, Somalia's Islamists (ICG, Brussels, 2005, Africa Report no. 100).

International Crisis Group, Somalia: The tough part is ahead (ICG, Brussels, 2007, Africa Briefing no. 45).

International Peace Academy (IPA), Mats Berdal \& David Malone (eds), Greed and Grievance: Economic agendas in civil Wars (Lynne Rienner, Boulder, CO/London, 2000).

Jackson, R. \& C. Rosberg, Personal Rule in Black Africa: Prince, autocrat, prophet and tyrant (University of California Press, Berkeley, CA, 1982).

Jasper, J.M., The Art of Moral Protest (The University of Chicago Press, Chicago, IL, 1997).

Joseph, Richard A., State, Conflict and Democracy in Africa (Praeger, London, 1999).

Joseph, Richard A., Democracy and Prebendal Politics in Nigeria (Cambridge University Press, Cambridge, 1987).

Kamara, Ousmane, 'Les divisions statutaires des descendants d'esclaves au Fuuta Tooro mauritanien', Journal des Africanistes, 70, 1-2 (2000), pp. 265-289.

Kane, Ousmane, Muslim Modernity in Postcolonial Nigeria: A study of the society for the removal of innovation and reinstatement of tradition (Brill, Leiden, 2003).

Kaplan, Seth, 'The remarkable story of Somaliland', Journal of Democracy, 19, 3 (2008), pp. 143-157.

Karamé, Kari H., 'Gender mainstreaming the peace-building process', in Kari H. Karamé (ed.), Gender and Peacebuilding in Africa (Norsk Utenrikspolitisk Institutt, Oslo, 2004), pp. 11-26.

Karamé, Kari H. (ed.), Gender and Peacebuilding in Africa (Norsk Utenrikspolitisk Institutt, Oslo, 2004).

Keane, J., Global Civil Society? (Cambridge University Press, Cambridge, 2003).

Keck, M. \& K. Sikkink, Activists beyond Borders: Advocacy networks in international politics (Cornell University Press, Ithaca, NY, 1998).

Klandermans, B., 'Mobilization and participation: social-psychological expansions of resource mobilization theory', American Sociological Review, 49, 5 (1984), pp. 583-600.

Klandermans, B., The Social Psychology of Protest (Blackwell, Oxford, 1997). 
Klandermans, B., 'The demand and supply of participation: Social-psychological correlates of participation in social movements,' in D.A. Snow, S.A. Soule \& H. Kriesi (eds), The Blackwell Companion to Social Movements (Blackwell, Oxford, 2004).

Klandermans, B., H. Kriesi \& S. Tarrow (eds), From Structure to Action: Comparing social movement research across cultures (JAI Press, Greenwich, CT, 1988).

Klandermans, B., J. van der Toorn \& J. van Stekelenburg, 'Embeddedness and grievances: Collective action participation among immigrants', American Sociological Review, 73 (2008), pp. 992-1012.

Koopmans, R., 'Political. Opportunity. Structure. Some splitting to balance the lumping', Sociological Forum, 14, (1999), pp. 93-105.

Koopmans, R., 'The missing link between structure and agency. Outline of an evolutionary approach to social movements', Mobilization, 10 (2005), pp. 19-36.

Kornhauser, W., The Politics of Mass Society (The Free Press, London, 1959).

Kriesi, H. \& D. Wisler, 'Direct democracy and social movements in Switzerland', European Journal of Political Research, 30 (1996), pp. 19-40.

Kriesi, H., R. Koopmans, J.W. Duyvendak \& M. Giugni, New Social Movements in Western Europe (University of Minnesota Press, Minneapolis, MN, 1995).

Kurzman, Charles, 'Conclusion: Social movement theory and Islamic studies', in Quintan Wiktorowicz (ed.), Islamic Activism: A social movement theory approach (Indiana University Press, Bloomington, 2004), pp. 289-303.

Lachenmann, Gudrun, 'Civil society and social movements in Africa: The case of the peasant movement in Senegal', The European Journal of Development Research, 5, 2, (1993), pp. 68-100.

Last, Murray, 'Towards a political history of youth in Muslim Northern Nigeria 17502000', in Jon Abbink \& Ineke van Kessel (eds), Vanguard or Vandals: Youth, politics and conflict in Africa (Brill, Leiden, 2005), pp. 37-54.

Last, Murray, 'Muslims and Christians in Nigeria: An economy of political panic', The Round Table: The Commonwealth Journal of International Affairs, 96, 392 (2007), pp. 605-616.

Le Sage, Andre, 'Prospects for Al Itihad and Islamist radicalism in Somalia,' Review of African Political Economy, 28, 89 (2001), pp. 472-473.

Leservoisier, Olivier, "Nous voulons notre part!” Les ambivalences du mouvement d'émancipation des Saafaalbe Hormankoobe de Djéol (Mauritanie)', Cahiers d'études africaines, 179-180 (2005), pp. 987-1014.

Lewis, Ioan M., 'Dualism in Somali notions of power', Journal of the Royal Anthropological Institute, 93 (1963), pp. 109-116.

Lewis, Ioan M., A Modern History of Somalia: Nation and State in the Horn of Africa (Westview Press, Boulder, 1988).

Lewis, Peter, 'From prebendalism to predation: The political economy of decline in Nigeria', Journal of Modern African Studies, 34, 1 (1996), pp. 79-103.

Leys, Colin, The Rise and Fall of Development Theory (James Currey, Oxford, 1996).

Lincoln, Bruce, Holy Terrors: Thinking about religion after September 11 (University of Chicago Press, Chicago, 2003).

Lindorfer, Simone, Assessment Report Liberia. Sexual and gender-based violence in Grand Gedeh, River Gee and Sinoe (2 to 30 November 2005) (Medica mondiale, Monrovia, 2005). 
Loimeier, Roman, Islamic Reform and Political Change in Northern Nigeria (Northwestern University Press, Evanston, IL, 1997).

Loimeier, Roman, 'Patterns and peculiarities of Islamic reform in Africa', Journal of Religion in Africa, 33, 3 (2003), pp. 237-262.

Lonsdale, J., 'Moral ethnicity and political tribalism', in P. Kaarsholm \& J. Hultin (eds), Inventions and Boundaries: Historical and anthropological approaches to the study of ethnicity and nationalism, Institute of Development Studies, Occasional Paper 11 (Roskilde University, Roskilde, 1994), pp. 131-150.

Lwanda, J., Kamuzu Banda of Malawi: A study in promise, power, and paralysis (Dudu Nsomba Publications, Glasgow, 1993).

Lwanda, J., Promises, Politics and Poverty: Democratic transition in Malawi (Dudu Nsomba Publications, Glasgow, 1996).

Maimbo, Samuel M., (ed.), Remittances and Economic Development in Somalia An Overview (World Bank, Washington, DC, 2006).

Mamdani, Mahmood, Citizen and Subject: Contemporary Africa and the legacy of late colonialism (Princeton University Press, Princeton, NJ, 1996).

Mamdani, Mahmood \& Ernest Wamba-dia-Wamba (eds), African Studies in Social Movements and Democracy (Codesria, Dakar, 1995).

Marchal, Roland, 'Islamic political dynamics in the Somali civil war', in: A. de Waal (ed.), Islamism and its Enemies in the Horn of Africa (C. Hurst \& Co., London, 2004), pp. 114-145.

Marchesin, Philippe, Tribus, ethnies et pouvoirs en Mauritanie (Karthala, Paris, 1992).

Marshall-Fratani, Ruth, 'Mediating the global and the local in Nigerian Pentecostalism', Journal of Religion in Africa, 28 (1998), pp. 278-315.

Marshall, Ruth A., Political Spiritualities: The explosion of Pentecostalism in Nigeria (Chicago University Press, Chicago/London, 2009).

Marty, Marianne, 'Les multiples usages de l'Islam dans le champ politique mauritanien', in Cédric Mayrargue (ed), L'Afrique politique 2002. Islams d'Afrique: Entre le local et le global (Karthala, Paris, 2003), pp. 51-68.

Marwell, G. \& P. Oliver, The Critical Mass in Collective Action: A micro-social theory (Cambridge University Press, Cambridge, 1993).

Mattes, R. \& R. Southall, 'Popular attitudes toward the South African electoral system', Democratization, 11, 1 (2004), pp. 51-76.

Mbembe, A., On the Postcolony (University of California Press, Berkeley/LA, 2001).

McAdam, D., Political Process and the Development of Black Insurgency, 1930-1970 (The University of Chicago Press, Chicago, IL, 1982).

McAdam, D., Freedom Summer (Oxford University Press, New York, 1988).

McCarthy, J. \& M.N. Zald, The Trend of Social Movements in America: Professionalization and resource mobilization (General Learning Corporation, Morristown, NJ, 1973).

McCarthy, J.D. \& M.N. Zald, 'Resource mobilization and social movements: A partial theory', American Journal of Sociology, 82, 6 (1977), pp. 1212-1241.

McAdam, D., J. McCarthy \& M.N.Zald, Comparative Perspectives on Social Movements (Cambridge University Press, Cambridge, 1996).

McAdam, D., J. McCarthy \& M.N. Zald (eds), Political Opportunities, Mobilizing Structures, and Cultural Framings (Cambridge University Press, New York, 1996).

McAdam, D., S. Tarrow \& C. Tilly, Dynamics of Contention (Cambridge University Press, Cambridge/New York, 2001). 
McAdam, D., S. Tarrow \& C. Tilly, 'Comparative perspectives on contentious politics', in M. Lichbach \& A. Zuckerman (eds), Ideas, Interests and Institutions: Advancing theory in comparative politics (Cambridge University Press, Cambridge, 2007).

McDougall, E. Ann, 'A topsy-turvy world: Slaves and freed slaves in the Mauritanian Adrar, 1910-1950', in S. Miers \& R. Roberts (eds), The End of Slavery in Africa (University of Wisconsin Press, Madison, WI, 2005), pp. 362-390.

McDougall, E. Ann, 'Living the legacy of slavery: between discourse and reality', Cahiers d'études africaines, 179-180 (2005), pp. 957-986.

McKinley, D., 'The rise of social movements in South Africa', in Debate: Voices from the South African left, May 2004, pp. 17-21.

McKinley, D. \& P. Naidoo, 'New Social Movements in South Africa: A story in creation', Development Update, 5, 2 (2004), pp. 9-22.

Meagher, Kate, 'Manufacturing disorder: Liberalization, informal enterprise and economic governance in African small firm clusters', Development and Change, 38, 3 (2007), pp. 473-503.

Medard, J-F., 'The underdeveloped state in tropical Africa: Political clientelism or neo-patrimonialism?', in C. Clapham (ed), Private Patronage and Public Power: Political clientelism in the modern state (Frances Pinter, London, 1982), pp. 162-192.

Melucci, A., Challenging Codes (Cambridge University Press, Cambridge, 1996).

Melucci, A., Nomads of the Present: Social movement and identity needs in contemporary society (Temple University Press, Philadelphia, PA, 1989).

Mengisteab, K. \& C. Daddieh, State Building and Democratization in Africa: Faith, hope, and realities (Praeger, London, 1999).

Mercer, John, Slavery in Mauritania today (Anti-Slavery International, London, 1981).

Messaoud, Boubacar, 'Esclavage en Mauritanie: De l'idéologie du silence la mise en question', Journal des Africanistes, 70, 1 (2000), pp. 291-337.

Meyer, D., and S. Tarrow (eds), Towards a Movement Society? Contentious politics for a new century (Rowman and Littlefield, Boulder, CO, 1998).

Mitchell, L., 'Living our Faith: The Lenten letter of the bishops of Malawi and the shift to multi party democracy, 1992-1993', Journal for the Scientific Study of Religion, 41, 1 (2002), pp. 5-18.

Molyneux, Maxine, 'Mobilization without emancipation? Women's interests, the state, and revolution in Nicaragua', Feminist Studies, 11, 2 (1985), pp. 227-254.

Moore, Henrietta, 'The differences within and the differences between', in T. del Valle (ed.), Gendered Anthropology (Routledge, London, 1993), pp. 193-219.

Moran, Mary H. 'Collective action and the "representation" of African women: A Liberian case study', Feminist Studies, 15, 3 (1989), pp. 443-460.

Moran, Mary H., Civilized Women: Gender and prestige in southeastern Liberia (Cornell University Press, Ithaca, N.Y., 1990)

Moran, Mary H., Liberia. The violence of democracy (University of Pennsylvania Press, Philadelphia, 2006).

Moran, Mary H. \& Anne Pitcher, "The "basket case" and the "poster child": Explaining the end of civil conflicts in Liberia and Mozambique', Third World Quarterly, 25, 3 (2004), pp. 501-519.

Moser, Caroline O.N. \& Fiona C. Clark, Victims, Perpetrators or Actors? Gender, armed conflict and political violence (Zed Books, London/New York, 2001). 
Muluzi, B., Y. Juwayeyi, M. Makhambera \& D. Phiri, Democracy with a Price: The history of Malawi since 1900 (Jhango Heinemann, Blantyre, 1999).

NASFAT, Code of Conduct (NASFAT Society, Lagos, 2005).

Newell, J., 'A moment of truth? The church and political change in Malawi', Journal of Modern African Studies, 33, 2 (1995), pp. 243-262.

Ngoma-Leslie, A., Social Movements and Democracy in Africa (Routledge, New York, 2006).

Norris, P., S. Walgrave \& P. van Aelst, 'Who demonstrates? Anti-state rebels, conventional participants, or everyone?', Comparative Politics, 37, 2 (2005), pp. 189- 205.

North, D., Institutions, Institutional Change and Economic Performance (Cambridge University Press, New York, 1990).

Nzogola-Ntalaja, G., 'Citizenship, political violence and democratization in Africa', Global Governance, 10 (2004), pp. 403-409.

Nzunda, M. \& K. Ross, Church, Law and Political Transformation in Malawi, 1992-1994 (Mambo Press, Gweru, 1995).

O’Brien, Susan, 'La charia contestée: Démocratie, débat et diversité; musulmane dans les "États charia" du Nigeria', Politique africaine, 106 (2007), pp. 46-68.

O'Donnell, Guillermo, 'On the state, democratization and some conceptual problems: A Latin American view with glances at some Post-Communist countries', World Development, 21, 8 (1993), pp. 1355-1369.

O’Donnell, G. \& P. Schmitter, Transitions From Authoritarian Rule: Tentative conclusions about uncertain democracies (John Hopkins University Press, Baltimore, 1986).

O’Maille, P., Living Dangerously: A memoir of political change in Malawi (Dudu Nsomba, Glasgow, 1999).

Obadare, Ebenezer, 'White-collar fundamentalism: Interrogating youth religiosity on Nigerian university campuses', Journal of Modern African Studies, 45, 4 (2007), pp. 517-537.

Obi, C., 'Environmental movements in sub-Saharan Africa: A political ecology of power and conflict, civil society and social movements. United Nations Research Institute for Social Development. Programme Paper 15, January 2005.

Offiong, Daniel A., Secret Cults in Nigerian Tertiary Institutions (Fourth Dimension, Enugu, 2003).

Olayode, Kehinde, 'Pro-democracy movements, democratisation and conflicts in Africa: Nigeria, 1990-1999', African Journal of International Affairs, 10, 1-2 (2007), pp. 127-146.

Oldfield, S. \& K. Stokke, 'Building unity in diversity: Social movement activism in the Western Cape anti-eviction campaign', in Richard Ballard, Adam Habib \& Imraan Valodia (eds), Voices of Protest: Social movements in post-apartheid South Africa (University of KwaZulu-Natal Press, Pietermaritzburg, 2006), pp. 111-132.

Olonisakin, Funmi, 'Women and the Liberian civil war', African Woman, MarchSeptember (1995), pp. 19-24.

Olupona, Jacob K. \& Terry Rey (eds), Orisa Devotion as World Religion: The globalization of Yoruba religious culture (University of Wisconsin Press, Madison, 2008). 
Olzak, Susan, 'Ethnic and nationalist social movements', in: David A. Snow, Sarah A. Soule \& Hanspeter Kriesi (eds), The Blackwell Companion to Social Movements (Blackwell/Malden, Oxford/Carlton, 2004) pp. 666-693.

Otayek, René, 'Introduction: des nouveaux intellectuels musulmans d'Afrique noire', in René Otayek (ed.), Le radicalisme islamique au sud du Sahara: Da'wa, arabisation et critique de l'Occident (Karthala, Paris, 1993), pp. 8-18.

Otayek, René \& Benjamin F. Soares, 'Introduction: Islam and Muslim politics in Africa', in Benjamin F. Soares \& René Otayek (eds), Islam and Muslim Politics in Africa (Palgrave Macmillan, New York, 2007), pp. 1-24.

Ould Ahmed Salem, Zekeria, 'Sur la formation des élites politiques et la mobilité sociale en Mauritanie', Nomadic Peoples, 2, 1-2 (1998), pp. 253-276.

Ould Ahmed Salem, Zekeria, 'La Centralité de la mobilisation tribale dans l'action politique en Mauritanie: Une illusion bien fondée?', L'Ouest Saharien, 2 (1999), pp. 127-156.

Ould Ahmed Salem, Zekeria, 'La démocratisation en Mauritanie, une illusion postcoloniale?', Politique africaine, 75 (October 1999), pp. 131-146.

Ould Ahmed Salem, Zekeria, 'Droit du statut personnel et équivalence citoyenne en République Islamique de Mauritanie. Le cas du mariage', La Pensée, 336 (2003), pp. 37-53.

Ould Ahmed Salem, Zekeria (ed.), Les trajectoires d'un État-frontière. Espaces, évolutions politiques et transformations sociales en Mauritanie (Codesria, Dakar, 2004).

Ould Ahmed Salem, Zekeria, 'Mauritania, a Saharan frontier state', Journal of North African Studies, 10, 3-4 (2005), pp. 491-506.

Ould Cheikh, Abdel Wedoud, 'L'évolution de l'esclavage dans la société maure', in E. Bernus \& P. Boilley (eds), Nomades et commandants. Administration et sociétés nomades dans l'ancienne AOF (Karthala, Paris, 1994), pp. 181-193.

Ould Saleck, El Arby, 'Les Haratin comme enjeu pour les partis politiques en Mauritanie', Journal des Africanistes, 70, 1 (2000), pp. 255-263.

Ould Saleck, El Arby, Les Haratins. Le paysage politique mauritanien (L'Harmattan, Paris, 2003).

Patel, N., 'Media in Malawi's democratic transition', in M. Ott, K. Phiri \& N. Patel, (eds), Malawi's Second Democratic Elections: Process, problems and prospects (Kachere Series, Zomba, 2000), pp. 158-185.

Patterson, Orlando, Slavery and social death (Harvard University Press, Cambridge, MA, 1982).

Peel, J.D.Y., 'Olaju: A Yoruba concept of development', The Journal of Development Studies, 14 (1978), pp. 135-165.

Peel, J.D.Y., 'The pastor and the babalawo: The interaction of religions in nineteenthcentury Yorubaland', Africa, 60, 3 (1990), pp. 338-369.

Peel, J.D.Y., Religious Encounter and the Making of the Yoruba (Indiana University Press, Bloomington, 2000).

Pithouse, Richard, 'Solidarity, co-option and assimilation: The necessity, promises and pitfalls of global linkages for South African movements', Development Update, 5, 2 (2004), pp. 169-199.

Piven, F.F. \& R.A. Cloward, Poor Peoples' Movements: Why they succeed, how they fail (Random House, New York, NY, 1977).

Polanyi, K., The Great Transformation (Beacon Press, Boston, 1957). 
Press, R., Peaceful Resistance: Advancing human rights and democratic freedoms (Ashgate, Aldershot, 2006).

Przeworski, A., Sustainable Democracy (Cambridge University Press, Cambridge, 1997).

Puechgirbal, Nadine, 'Involving women in peace processes: Lessons learnt from four African countries (Burundi, DRC, Liberia and Sierra Leone)', in Kari H. Karamé (ed.), Gender and Peacebuilding in Africa (Norsk Utenrikspolitisk Institutt, Oslo, 2004), pp. 47-66.

Putnam, R., Making Democracy Work: Civic traditions in modern Italy (Princeton University Press, Princeton, NJ, 1993).

Quirk, Joel, Unfinished Business: A comparative survey of historical and contemporary slavery (UNESCO, Paris, 2008).

Reichmuth, Stefan, 'The modernization of Islamic education: Islamic learning and its interaction with 'Western' education in Ilorin, Nigeria', in Louis Brenner (ed.), Muslim Identity and Social Change in Sub-Saharan Africa (Indiana University Press, Bloomington, 1993), pp. 179-197.

Reichmuth, Stefan, 'Education and the growth of religious associations among Yoruba Muslims: the Ansar-Ud-Deen Society of Nigeria', Journal of Religion in Africa, 26, 4 (1996), pp. 365-405.

Reichmuth, Stefan, Islamische Bildung und soziale Integration in Ilorin (Nigeria) seit ca. 1800 ( LIT Verlag, Münster, 1998).

Reno, William, Warlord Politics and African States (Lynne Rienner Publishers, Boulder, CO, 1998).

Report of the Monitoring Group on Somalia pursuant to Security Council resolution 1676 (2006), UN document S/2006/913.

Report of the Monitoring Group on Somalia pursuant to Security Council resolution 1676 (2006), UN document S/2007/436.

Report of the Monitoring Group on Somalia pursuant to Security Council resolution 1766(2007), UN document S/2008/274.

Rheingold, H., Smart Mobs: The next social revolution (Perseus, Cambridge, MA, 2002).

Robins, Steven L. (ed.), Limits to Liberation after Apartheid: Citizenship, governance and culture (James Currey, Oxford, 2005).

Rodney, Walter, How Europe Underdeveloped Africa (Bogle-L'Ouverture Publications, London, 1972).

Ross, K., 'The Transformation of Power in Malawi, 1992-94: The role of the Christian churches,' in Ross K. (ed.), God, People and Power in Malawi: Democratization in theological perspective (CLAIM, Blantyre, 1996).

Roy, Olivier, The Failure of Political Islam (Harvard University Press, Cambridge, MA, 1994).

Roy, Olivier, Globalised Islam: The search for a new ummah (Hurst, London, 2004).

Rudnyckyj, Daromir, 'Market Islam in Indonesia', Journal of the Royal Anthropological Institute (N.S.), 15, s1 (2009), pp. 182-200.

Ruf, Urs Peter, Ending Slavery: Hierarchy, dependency and gender in central Mauritania (Transcript Verlag, Bielefeld, 1999).

Runciman, W.G., Relative Deprivation and Social Justice (Routledge, London,1966).

Rustomjee, C., 'From economic debt to moral debt: The campaigns of jubilee South Africa', in Richard Ballard, Adam Habib \& Imraan Valodia (eds), Voices of Protest: 
Social movements in post-apartheid South Africa (University of KwaZulu-Natal Press, Pietermaritzburg, 2006) pp. 279-300.

Ryan, Patrick J., Imale: Yoruba participation in the Muslim tradition, a study of clerical piety (Scholars Press, Missoula, MT, 1978).

Salih, M., Environmental Politics and Liberation in Contemporary Africa (Kluwer Academic Publishers, London, 1999).

Sall, Ebrima, 'Social movements in the renegotiation of the bases for citizenship in West Africa', Current Sociology, 52, 4, (2004), pp. 595-614.

Samatar, Said S., 'Unhappy masses and the challenge of political Islam in the Horn of Africa', Horn of Africa, 20, (2002), pp. 1-10.

Sanni, Amidu, 'Challenges and realities in the healing and power accession custom of the Yoruba Muslims of Nigeria', Journal of Oriental and African Studies, 15 (2006), pp. 145-156.

Saul, John S., The Next Liberation struggle: Capitalism, socialism and democracy in Southern Africa (University of KwaZulu-Natal Press, Scotsville, 2005).

Sawyer, Amos, The Emergence of Autocracy in Liberia. Tragedy and challenge (Institute for Contemporary Studies, San Francisco, 1992).

Schedler, A., 'Taking uncertainty seriously: The blurred boundaries of democratic transition and consolidation', Democratization, 8, 4 (2001), pp. 1-22.

Seibel, Hans D. \& Andreas Massing, Traditional Organizations and Economic Development. Studies in indigenous cooperatives in Liberia (Praeger Publishers, New York, 1974).

Sindima, H., Malawi's First Republic: An economic and political analysis (University Press of America, New York, 2002).

Smelser, N.L., Theory of Collective Behavior (The Free Press, London,1962).

Smillie, Ian, 'The Kimberley Process: The case for proper monitoring'. Occasional Paper 5 (Partnership Africa Canada, Ottawa, 2002).

Smillie, Ian, Lansana Gberie \& Ralph Hazleton, 'The Heart of the Matter: Sierra Leone, diamonds and human security' (Partnership Africa Canada, Ottawa, 2000).

Smith, Christian, 'Correcting a curious neglect, or bringing religion back in', in: $\mathrm{C}$. Smith (ed.), Disruptive Religion. The force of faith in social movement activism (Routledge, New York, London, 1996), pp. 1-25.

Snow, D.A., E.B. Rochford, S.K. Worden \& R.D. Benford, 'Frame alignment processes, micromobilization, and movement participation', American Sociological Review, 51 (1986), pp. 464-481.

Snow, D.A. \& P. Oliver, 'Social movements and collective behavior: social psychological considerations and dimensions', in K.S. Cook, G.A. Fine \& J.S. House (eds), Sociological Perspectives on Social Psychology (Allyn and Bacon, Boston, MA, 1995).

Snow, David A. \& Doug McAdam, 'Identity Work Processes in the Context of Social Movements: Clarifying the identity/movement nexus', in S. Stryker, T. Owens \& R.W. White (eds), Self, Identity and Social Movements (University of Minnesota Press, Minneapolis, 2000), pp. 41-67.

Snow, D.A., S.A. Soule \& H. Kriesi (eds), The Blackwell Companion to Social Movements (Blackwell Publishing, Oxford, 2004).

Soares, Benjamin F. (ed.), Muslim-Christian encounters in Africa (Brill, Leiden, 2006).

Soares, Benjamin F. \& René Otayek (eds), Islam and Muslim Politics in Africa (Palgrave Macmillan, New York, 2007). 
Soares, Benjamin \& Filippo Osella, 'Islam, politics, anthropology', Journal of the Royal Anthropological Institute (N.S.), 15, 1 (2009), pp. 1-23.

Soyinka, Wole, Cults: A people in denial (Interventions III, Bookcraft, Ibadan, 2005).

Stewart, Charles C., 'Une interprétation du conflit sénégalo-mauritanien', Revue $d u$ Monde Musulman et de la Méditerranée, 54, 1 (1989), pp. 161-170.

Stryker, S., T.J. Owens \& R.W. White (eds), Self, Identity, and Social Movements (Minnesota Press, Minneapolis, MN, 2000).

Sy, Yaya, 'L'esclavage chez les Soninkés: du village Paris', Journal des Africanistes, 70, 1-2 (2000), pp. 43-69.

Tadesse, Medhane, Al-Ittihad: Political Islam and Black Economy in Somalia (Mega Printing, Addis Ababa, 2002).

Tajfel, H. \& J.C. Turner, 'An integrative theory of intergroup conflict', in S. Worchel \& W.G. Austin (eds), The Social Psychology of Intergroup Relations (Brooks/Cole, Monterey, CA, 1979), pp. 33-47.

Tamuno, Tekena \& Robin Horton, 'The changing position of secret societies and cults in modern Nigeria', African Notes, 5, 2 (1969), pp. 36-62.

Tarrow, S., Democracy and Disorder: Protest and politics in Italy 1965-1975 (Clarendon Press, Oxford, 1989).

Tarrow, S., Power in Movement: Social movements, collective action and politics (Cambridge Press, New York, 1994).

Tarrow, S., Power in Movement: Social movements and contentious politics (Cambridge University Press, Cambridge, 1998).

Tarrow, S., 'Bridging the quantitative-qualitative divide', in H. E. Brady and D. Collier (eds), Rethinking Social Inquiry: Diverse tools, shared standards (Rowman and Littlefield, Lanham, MD, 2004), pp. 171-180.

Tarrow, S. \& D. McAdam, 'Scale shift in transnational contention', in D. della Porta \& S. Tarrow (eds), Transnational Protest and Global Activism (Rowman and Littlefield, Lanham, MD, 2005).

Taylor, Rupert, Creating a Better World: Interpreting global civil society (Kumarian Press, Bloomfield, 2005).

Taylor, Verta, 'Mobilizing for change in a social movement society', Contemporary Sociology, 29, 1 (2000), pp. 219-230.

Tilly, Charles, From Mobilization to Revolution (Addison-Wesley, Reading, MA, 1978).

Tilly, Charles, 'Social movements and national politics', in C. Bright \& S. Hardine (eds), Statemaking and Social Movements: Essays in history and theory (University of Michigan Press, Ann Arbor, MI, 1984).

Tilly, Charles, The Contentious French (The Belknap Press of Harvard University Press, Cambridge, MA, 1986).

Tilly, Charles, 'From interactions to outcomes in social movements', in: M. Giugni et al. (eds), How Social Movements Matter (University of Minnesota Press, Lanham, MD, 1999), pp. 253-270.

Tilly, Charles, Social Movements, 1768-2004 (Paradigm Publishers, Boulder, CO/London, 2004).

Tonkin, Elizabeth, 'Model and ideology: dimensions of being "civilised" in Liberia', in L. Holy \& M. Stuchlik (eds), The Structure of Folk Models. ASA Monograph 20 (Academic Press, London, 1981), pp. 307-330. 
Touraine, A., The Voice and the Eye: An analysis of social movements (Cambridge University Press, Cambridge, 1981)

Tyler, T.R. \& H.J. Smith, 'Social justice and social movements', in D.T. Gilbert \& S.T. Fiske (eds), Handbook of Social Psychology, 4th ed. (McGraw-Hill, Oxford, 1998), pp. 595-629.

Umar, Muhammad Sani, 'Education and Islamic trends in Northern Nigeria: 1970s1990s', Africa Today, 48, 2 (2001), pp. 127-150.

Umar, Muhammad Sani, 'Profiles of new Islamic schools in Northern Nigeria', The Maghreb Review, 28, 2-3 (2003), pp. 145-169.

United Nations Joint Logistics Center, NGO-SPAS, 'Somalia - security update, report no. 44/06', 26 Oct.-1 Nov. 2006).

UNRISD, Transformative Social Policy Lessons from UNRISD Research, UNRISD Research and Policy Brief 5 (2006).

Van Kessel, Ineke, 'Beyond our Wildest Dreams': The United Democratic Front and the transformation of South Africa (University Press of Virginia, Charlottesville/ London, 2000).

Van Stekelenburg, J. \& B. Klandermans, 'Individuals in movements: A social psychology of contention', in B. Klandermans \& C.M. Roggeband (eds), The Handbook of Social Movements Across Disciplines (Springer, New York, 2007), pp. 157-204.

Van Stekelenburg, J., B. Klandermans \& W.W. van Dijk, 'Context matters: Explaining why and how mobilizing context influences motivational dynamics', Journal of Social Issues (forthcoming, 2009).

Walsh, E.J., 'Resource mobilization and citizen protest in communities around Three Mile Island', Social Problems, 29, 1 (1981), pp. 1-21.

WANEP \& WIPNET, Women's National Agenda for Peace, Security and Development in Post-War Liberia. Adopted 30th March 2006 (Women in Peace Network, Monrovia, 2006).

Wellman, B., 'The network community', in B. Wellman (ed.), Networks in the Global Village (Westview, Boulder, CO, 1999), pp. 1-48.

Whiteford, A. \& D.E. Van Seventer, 'South Africa's changing income distribution in the 1990s', Studies in Economics and Econometrics, 24, 3 (2000), pp. 7-30.

Wiktorowicz, Quintan (ed.), Islamic Activism: A social movement theory approach (Indiana University Press, Bloomington, IN, 2004).

Wiktorowicz, Quintan, 'Introduction: Islamic activism and social movement theory', in Q. Wiktorowicz (ed.), Islamic Activism: A social movement approach (Indiana University Press, Bloomington, IN, 2004), pp. 1-36.

Wilmot, Patrick, Nigeria: The nightmare scenario (Interventions VI, Bookcraft and Farafina, Ibadan and Lagos, 2007).

Young, Crawford, 'Contextualizing Congo conflicts', in John F. Clark (ed.), The African Stakes in the Congo War (Fountain Publishers, Kampala, 2002).

Young, I.M., Justice and the Politics of Difference (Princeton University Press, Princeton, 1990).

Young, I.M., Inclusion and Democracy (Oxford University Press, Oxford, 2000). 



\section{List of authors}

Jon Abbink is a senior researcher at the African Studies Centre Leiden, where he heads the research group on 'Social Movements and Political Culture in Africa'. He is also Professor of African ethnic studies at the Department of Anthropology, VU University, Amsterdam. His research interests are political change and religious culture in Northeast Africa, ethnicity in Africa, and the anthropology and history of Ethiopia, subjects on which he published widely.

abbink@ascleiden.nl

Boniface Dulani is a Lecturer in Political Science at the University of Malawi, Chancellor College, Zomba. He has published on government and democracy in Africa, the role of civil society and faith based organizations in democracy, public sector reforms and elections. He is currently finishing his $\mathrm{PhD}$ in Comparative African Politics at Michigan State University on the topic of presidential term limits in Africa's new democracies.

ntwee2002@yahoo.co.uk

Stephen Ellis is a senior researcher at the African Studies Centre, Leiden, and Desmond Tutu professor in the Faculty of Social Sciences at the VU University, Amsterdam. He has published on a wide variety of African countries including Liberia, Madagascar, Nigeria and South Africa. His most recent book, coauthored with Solofo Randrianja, is Madagascar: A Short History (C. Hurst \& Co., London).

ellis@ascleiden.nl

Veronika Fuest works as adviser for research development in the humanities and social sciences at the University of Göttingen, Germany. As a previous member of various research projects at different institutes she has published on a range of topics including various aspects of Liberian society, management of water resources in Ghana and practices of cooperative research. Her most recent work constitutes a continuation of her $\mathrm{PhD}$ research on women's social and economic strategies in pre-war Liberia.

V.Fuest@gmx.de

Lansana Gberie is an academic and writer, and is the author of $A$ Dirty War in West Africa: The RUF and the Destruction of Sierra Leone (C. Hurst \& Co., London, 2005). Gberie was a key researcher for Partnership Africa Canada's Human Security and International Diamond Trade project (PAC). He was coauthor of The Heart of the Matter: Sierra Leone, Diamonds and Human Security (Ottawa, 2000). He has since authored many reports and studies for the 
Project, and was editor of the Sierra Leone Annual Diamond Review published by PAC.

lagberie@yahoo.com

Adam Habib is Deputy Vice-Chancellor Research, Innovation and Advancement at the University of Johannesburg, South Africa. He has published extensively on the South African transition particularly in the thematic areas of democratisation, political economy, civil society and foreign policy. His recent co-edited books are Voices of Protest: Social Movements in Post-Apartheid South Africa (University of Natal Press, 2006), and Racial Redress and Citizenship in Contemporary South Africa (Cape Town, HSRC Press, 2008). ahabib@uj.ac.za

Bert Klandermans is Professor in Applied Social Psychology at the VU University, Amsterdam. He has published extensively on the social psychology of participation in social movements and is the editor of Social Movements, Protest, and Contention, a book series published by the University of Minnesota Press. His publications include Social Psychology of Protest (Blackwell, 1997) and the co-edited volumes Methods of Social Movement Research (University of Minnesota Press, 2002), Extreme Right Activists in Europe (Routledge, 2006), and Handbook of Social Movements Across Disciplines (Springer, 2007). PG.Klandermans@fsw.vu.nl

Paul Opoku-Mensah is an Associate Professor of Development and International Relations at Aalborg University, Denmark, and the Deputy Director of the Comparative Research Programme on NGOs, University of Bergen, Norway. His writings include "the State of Civil Society in sub-Saharan Africa" (in Comparative Perspectives on Civil Society, Kumarian, 2007); Reconceptualising NGOs and their roles in Development (2007, lead editor), and NGOs and the Politics of African Development: The Ghanaian Experience (VDM, 2009). paulom@,ihis.aau.dk

Zekeria Ould Ahmed Salem is Professor of Political Science at the University of Nouakchott, Mauritania. Recent publications include "Islam in Mauritania between Political Expansion and Globalization: Elites, Institutions, Knowledge, and Networks", in B. Soares and R. Otayek, eds., Islam and Muslim Politics in Africa, (Palgrave Macmillan, 2007); "Mauritania: A Saharan Frontier State", The Journal of North African Studies, Volume 10, Issue 3/4, September 2005, pp. 491-506. He is the editor of Les trajectories d'un Etat-frontière - Espaces, evolution politique et transformations sociales en Mauritanie, Dakar, Codesria, 2004.

zakariadenna@yahoo.fr 
Benjamin Soares, an anthropologist, is a senior researcher at the African Studies Centre in Leiden. His publications include Islam and the Prayer Economy (Edinburgh University Press, 2005) and the co-edited volumes, Islam, Politics, Anthropology (Wiley-Blackwell, 2009) and Islam and Muslim Politics in Africa (Palgrave MacMillan, 2007).

bsoares@ascleiden.nl

Ineke van Kessel is a senior researcher with the African Studies Centre, Leiden. She has published extensively on anti-apartheid resistance in South Africa notably 'Beyond our Wildest Dreams': The United Democratic Front and the Transformation of South Africa (University of Virginia Press, 2000) - as well as on socio-political developments in post-apartheid South Africa.

kessel@ascleiden.nl

Jacquelien van Stekelenburg is a post-doc researcher at the Sociology Department of the VU University, Amsterdam. Her publications focus on the social psychological dynamics of moderate and radical protest participation with a special interest in group identification, emotions and ideologies as motivators for action. In 2006 she defended her PhD thesis entitled Promoting or Preventing Social Change. Instrumentality, identity, ideology and groups-based anger as motives of protest participation.

J.van.Stekelenburg@,fsw.vu.nl 